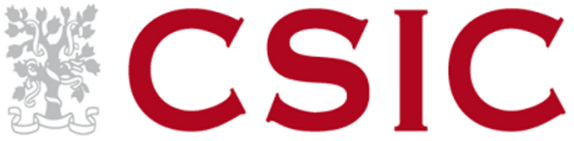

CONSEJO SUPERIOR DE INVESTIGACIONES CIENTÍFICAS

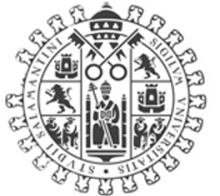

VNIVERSIDAD

BSALAMANCA

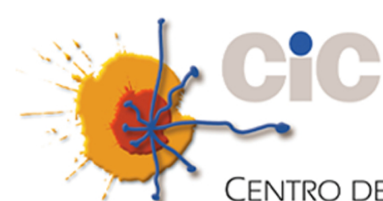

DEL CÁNCER

CAMPUS DE EXCELENCIA INTERNACIONAL

\title{
IMPLICACIÓN DE LAS QUINASAS HUMANAS VRK1 Y VRK2 EN LAS RUTAS DE RESPUESTA A DAÑO GÉNICO Y APOPTOSIS
}

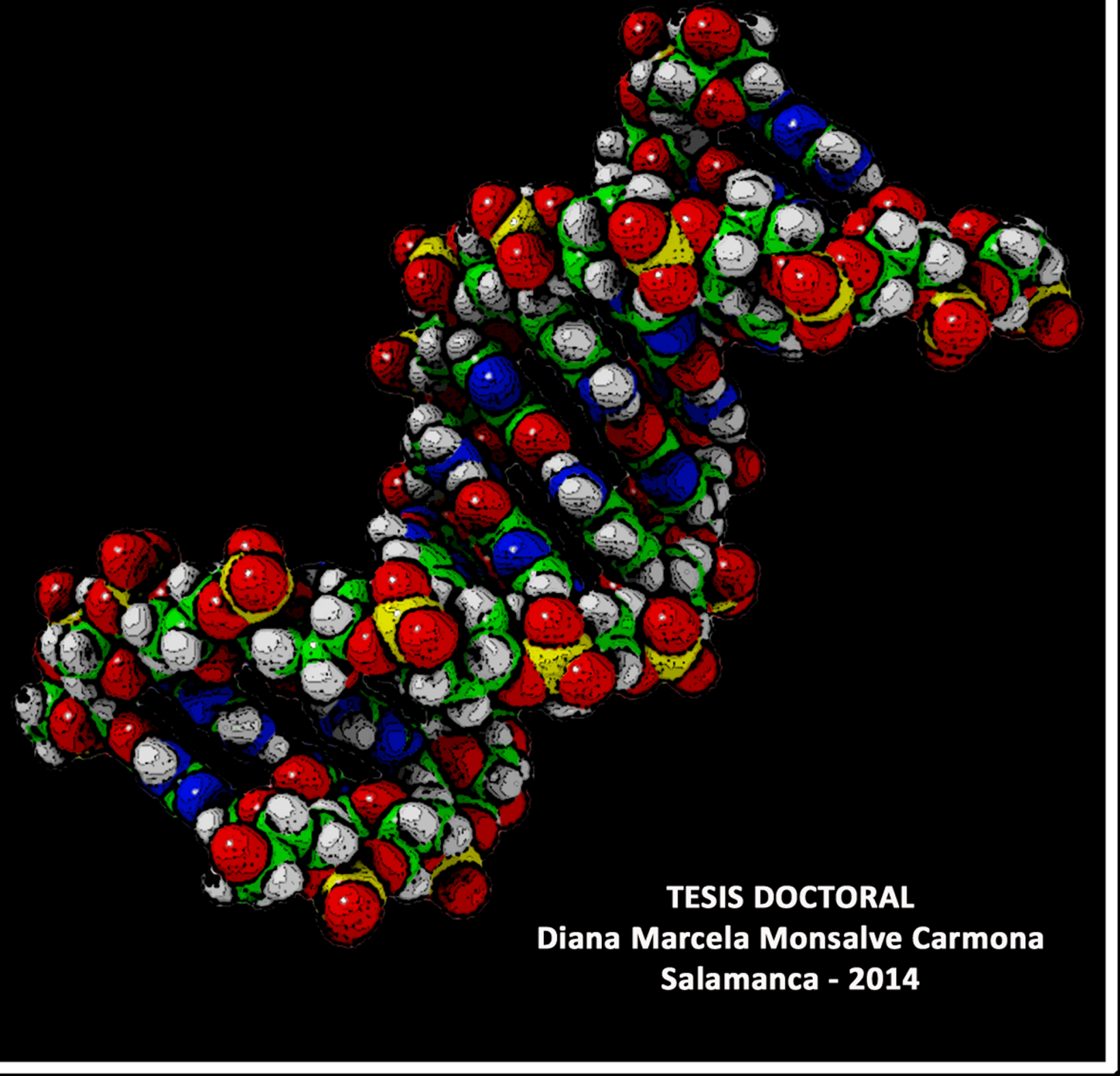





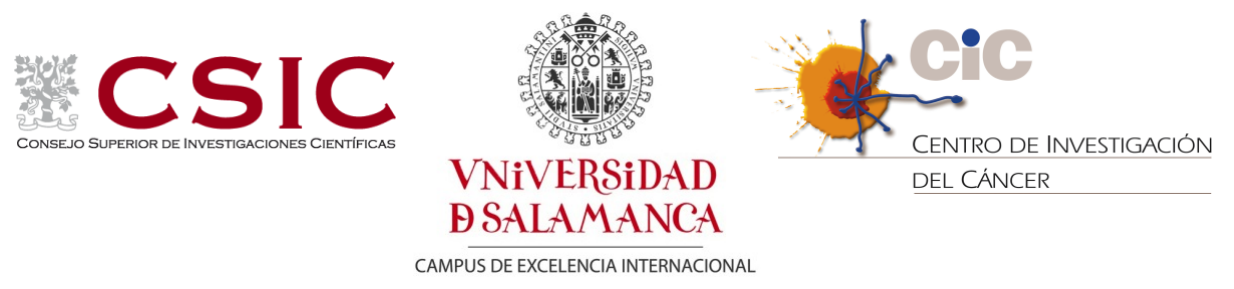

CENTRO DE INVESTIGACIÓN DEL CÁNCER

INSTITUTO DE BIOLOGÍA MOLECULAR Y CELULAR DEL CÁNCER

(CSIC-USAL)

\section{IMPLICACIÓN DE LAS QUINASAS HUMANAS \\ VRK1 Y VRK2 EN LAS RUTAS DE RESPUESTA A DAÑO GÉNICO Y APOPTOSIS}

TESIS DOCTORAL

Diana Marcela Monsalve Carmona

Salamanca, España

2014 



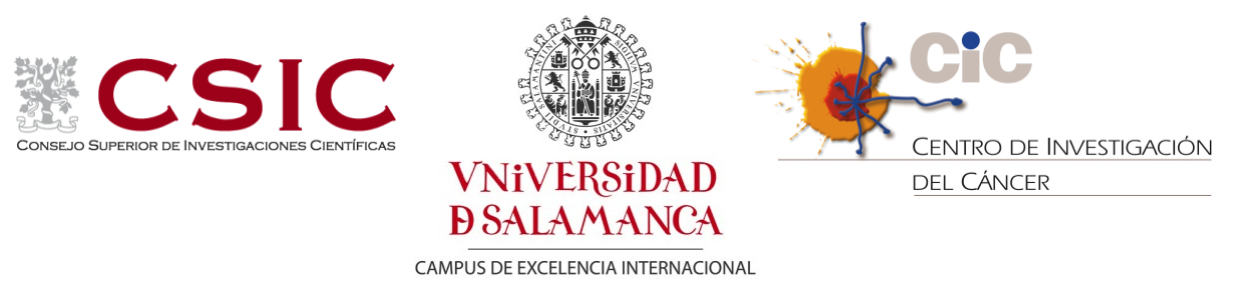

D. Pedro A. Lazo-Zbikowski, profesor de investigación del Consejo superior de Investigaciones Científicas (CSIC),

\section{CERTIFICA:}

Que la memoria titulada "Implicación de las quinasas humanas VRK1 y VRK2 en las rutas de respuesta a daño génico y apoptosis" presentada por la licenciada en bacteriología y laboratorio clínico Diana Marcela Monsalve Carmona, ha sido realizada bajo su dirección en el Instituto de Biología Molecular y Celular del Cáncer y reúne, a su juicio, originalidad y contenidos suficientes para que sea presentada ante el tribunal correspondiente y optar al grado de doctor por la Universidad de Salamanca.

Y para que así conste a efectos legales, expide el presente certificado en Salamanca, a 20 de febrero de 2014.

Fdo. Pedro A. Lazo-Zbikowski 

Esta memoria ha sido realizada siendo DIANA MARCELA MONSALVE

CARMONA beneficiaria de una beca predoctoral JAE del Consejo Superior de Investigaciones Científicas (CSIC) para la realización de la tesis doctoral (2008-2012).

La investigación en el laboratorio ha sido financiada por los siguientes proyectos:

Ministerio de Educación y Ciencia (SAF2007-60242)

Ministerio de Educación y Ciencia, CONSOLIDER-INGENIO2010 (CSD007-0017)

Ministerio de Ciencia e Innovación (SAF2010-14935)

Junta de Castilla y León, Consejería de Educación (CSI14A08)

Junta de Castilla y León, Consejería de Sanidad (SAN/673/SA05/08)

Junta de Castilla y León, Consejería de Educación (CSI006A11-2) 

Paso a paso, caer y volver a levantarse, aprender de los errores, cada pequeña experiencia que nos hace quienes somos. Esta memoria está dedicada a todos aquellos obstinados que nunca se han rendido.

A mi familia, y en especial a ti papi donde quiera que te encuentres.

"Sólo aquellos que se arriesgan a ir muy lejos, pueden llegar a saber lo lejos que pueden ir"

T.S. Elliot 



\section{TABLA DE CONTENIDOS}

Glosario de abreviaturas vii

Índice de figuras $\quad x i$

Índice de tablas $\quad$ xV

$\begin{array}{ll}\text { Introducción } & 1\end{array}$

1. Daño y reparación del ADN 3

1.1 Tipos de daño 3

1.1.1 Daño en el ADN por procesos celulares endógenos 4

1.1.2 Daño en el ADN por agentes exógenos 5

1.2 Daño y reparación de cadena sencilla del ADN 5

1.2.1 Mecanismos de reparación de cadena sencilla 6

1.3 Daño y reparación de la doble cadena del ADN 9

1.3.1 Detección de DSBs y activación de las proteínas

sensoras $\quad 11$

1.3.2 El complejo MRN (Mre11-Rad50-NBS1) actúa como sensor de las DSBs $\quad 12$

1.3.3 Papel de $\mathrm{\gamma H} 2 \mathrm{AX}$ y reclutamiento de las proteínas mediadoras MDC1, 53BP1 y BRCA1 17

1.3.4 Función de las proteínas transductoras (PIIKs, Chk1 y Chk2) y efectoras ( $p 53$ y Cdc25) en la respuesta al daño en el ADN

1.3.5 Vías de reparación de las DSBs: reparación por unión de los extremos no homólogos y recombinación homóloga

1.3.6 Papel de la ubiquitinación en la respuesta al daño en el ADN

1.3.7 Desensamblaje de focos de reparación 26

$\begin{array}{ll}1.4 \text { Daño en el ADN y cáncer } & 27\end{array}$

2. Apoptosis 30

2.1 Caspasas 31

2.2 Ruta extrínseca o de los receptores de muerte 32

2.3 Ruta intrínseca o ruta mitocondrial 32 
2.3.1 Regulación de la apoptosis por proteínas de la familia Bcl-2

2.3.2 Permeabilización de la membrana externa mitocondrial (MOMP) por Bax y Bak $\quad 36$

2.3.3 Activación de Bax y Bak 37

$\begin{array}{ll}2.4 \text { Fase de ejecución } & 40\end{array}$

2.5 Apoptosis y cáncer $\quad 41$

3. Las proteínas quinasas $\quad 42$

3.1 La familia de quinasas humanas VRK 43

3.2 Estructura de las quinasas humanas VRK 44

3.3 La quinasa humana VRK1 46

3.3.1 Localización subcelular de VRK1 46

3.3.2 Implicación de VRK1 en proliferación y progresión del ciclo celular $\quad 47$

3.3.3 Regulación de diferentes factores de transcripción por VRK1 48

3.3.4 Fosforilación de la histona H3 por VRK1 50

3.3.5 VRK1 y su participación en el ensamblaje de la envoltura nuclear 51

3.3.6 VRK1 en la fragmentación del aparato de Golgi 52

3.3.7 Implicación de VRK1 en neurodegeneración 52

3.4 La quinasa humana VRK2 53

3.4.1 Funciones de la quinasa humana VRK2 54

3.5 Regulación de las quinasas humanas VRK 58

3.6 La pseudoquinasa humana VRK3 $\quad 59$

3.7 Ratones Knock-out de VRK1 y VRK2 59

$\begin{array}{ll}\text { Objetivos } & 61\end{array}$

$\begin{array}{ll}\text { Materiales y métodos } & 63\end{array}$

1. Técnicas de manipulación del ADN 65

1.1 Obtención y purificación de ADN plasmídico de E. Coli 65

1.2 Cuantificación de ADN plasmídico 65

1.3 Electroforesis de ácidos nucleicos en gel de agarosa 65

1.4 Generación de vectores de ADN recombinante 66

1.5 Transformación de plásmidos en E. Coli 66

$\begin{array}{ll}1.6 \text { Mutagénesis dirigida } & 67\end{array}$

2. Técnicas de manipulación de proteínas 67 
2.1 Purificación de proteínas de fusión con GST 67

2.2 Electroforesis en geles SDS-PAGE $\quad 68$

2.3 Tinción con azul de Coomassie $\quad 69$

2.4 Transferencia húmeda y Western blot de extractos proteicos $\quad 69$

2.5 Tinción con rojo Ponceau $\quad 70$

3. Cultivo de líneas celulares $\quad \mathbf{7 0}$

4. Transfecciones transitorias de ADN en células eucariotas en cultivo $\begin{array}{ll}\text { monocapa } & 71\end{array}$

4.1 Transfección con JetPEI $\quad 71$

4.2 Transfección con Lipofectamine $\quad 71$

4.3 Supresión de la expresión génica mediante ARNi 72

5. Obtención de extractos proteicos de células en cultivo 72

6. Cuantificación de proteínas $\quad 72$

7. Ensayos de interacción entre proteínas $\quad 72$

$\begin{array}{ll}7.1 \text { Ensayos de coinmunoprecipitación } & 72\end{array}$

$\begin{array}{ll}7.2 \text { Ensayos de Pull-Down } & 73\end{array}$

8. RT-PCR cuantitativa en tiempo real $\quad \mathbf{7 4}$

9. Determinación de la actividad transcripcional con genes
reporteros de luciferasa

10. Inmunofluorescencia y microscopía confocal 75

11. Ensayos de actividad quinasa $\quad 76$

12. Fraccionamiento subcelular para separación de citosol y $\begin{array}{ll}\text { mitocondrias } & 76\end{array}$

13. Ensayo TUNEL $\quad 77$

14. Reactivos y estimulaciones $\quad 77$

$\begin{array}{lr}\text { Resultados } & 87\end{array}$

1. Implicación de la quinasa humana VRK1 en la respuesta al daño $\begin{array}{ll}\text { génico } & 89\end{array}$

1.1 VRK1 en la respuesta al daño en el ADN 89

1.1.1 Localización subcelular de VRK1 89

1.1.2 El daño en el ADN incrementa la actividad de VRK1 90

1.2 Efecto de diferentes tipos de daño (radiación ionizante o

fármacos quimioterapéuticos) sobre el ADN

1.2.1 Efecto de radiación ionizante en diferentes líneas

celulares (formación de focos de NBS1, MDC1 y

53BP1)

1.2.2 Formación de focos de reparación a diferentes dosis de radiación ionizante 
1.2.3 Cinética de formación de focos de reparación en respuesta a radiación ionizante

1.3 Papel de VRK1 sobre la proteína mediadora MDC1 en respuesta al daño en el ADN

101

1.3.1 VRK1 interacciona con MDC1 pero no afecta su reclutamiento a los focos de reparación en respuesta al daño génico

1.3.2 VRK1 es necesaria para el ensamblaje de focos de 53BP1 pero no de MDC1

108

1.4 VRK1 y la proteína NBS1

111

1.4.1 VRK1 interacciona con NBS1 independiente del daño en el ADN

1.4.2 NBS1 es diana de fosforilación de VRK1 focos de NBS1 en respuesta a radiación ionizante

1.4.4 El efecto de VRK1 sobre los focos de NBS1 es independiente de ATM

1.4.5 VRK1 y ATM son necesarias para mantener los niveles proteicos de NBS1

1.4.6 VRK1 no interviene en la expresión génica de NBS1

1.4.7 VRK1 protege a NBS1 de la degradación por el proteasoma

1.4.8 RNF8 media la degradación de NBS1 en células deficientes de ATM

2. Implicación de la quinasa humana VRK2 en apoptosis

141

2.1 Localización subcelular y expresión de VRK2

2.2 Interacción de VRK2 con proteínas relacionadas con la apoptosis

2.2.1 VRK2 colocaliza con $B c l-x L$ y Bax, pero únicamente interacciona con $\mathrm{Bcl}-\mathrm{xL}$

2.3 VRK2 regula la expresión de la proteína pro-apoptótica Bax 145

2.3.1 VRK2 regula la expresión génica de Bax

146

2.4 El silenciamiento de la expresión de VRK2 induce la liberación del citocromo c y el procesamiento de PARP

2.5 El silenciamiento de la expresión de VRK2 sensibiliza las células al tratamiento con camptotecina 
1. Implicación de la quinasa humana VRK1 en la respuesta al daño en el ADN

1.1 Actividad y localización de VRK1 en respuesta a estímulos genotóxicos

1.2 Papel de VRK1 sobre proteínas clave en la reparación del ADN

1.3 Papel de VRK1 en la degradación de NBS1

2. Implicación de la quinasa humana VRK2 en la ruta de la apoptosis

2.1 Expresión y localización subcelular de VRK2

2.2 VRK2A y su relación con la apoptosis

2.3 VRK2 protege a las células de la apoptosis

Agradecimientos 


\section{GLOSARIO DE ABREVIATURAS}

A

A1/BFL-1: Bcl-2 related protein A1

aa: aminoácidos

ADN: ácido desoxiribonucleico

AP: apurínico

ARN: ácido ribonucleico

ARNi: ARN de interferencia

ARNm: ARN mensajero

ATF2: activating transcription factor 2

ATLD: ataxia talangiectasia like

desorder

ATM: ataxia talangiectasia mutated

ATP: adenosine triphosphate

ATR: ataxia talangiectasia and Rad3 relates

\section{B}

BAF: barrier to autointegration factor Bak: BCl-2 homologous antagonist killer Bax: $B C l-2$ associated $x$ protein Bcl-2: B-cell leukemia/lymphoma 2 $\mathrm{BCl}-\mathrm{xL}$ : $B$ cell lymphoma-extra large BER: base excision repair

BH: BCl-2 homology

Bid: $B H 3$ interacting domain death agonist

Bik: $B C l-2$ interacting killer

Bim/Bcl2-L-11: Bcl-2 like protein 11

Bmf: $B C l-2$ modifying factor

Bok: $B C l-2$ related ovarian killer

BRCA1: breast cancer associated 1

BRCT: breast cancer associated $1 \mathrm{c}$ terminus

BSA: bovine serum albumin

\section{C}

CARD: caspase activation and
recruitment domains

Chk1: checkpoint kinase 1

Chk2: checkpoint kinase 2

CKI: casein kinase I

CKII: casein kinase II

CREB: CAMP response element binding

$\mathrm{CS}$ : cockayne syndrome
D

DAPI: 4',6', DiAmidino-2-Phenil Indol

DDR: DNA damage response

DED: death effector domain

DISC: death inducing signaling complex

DMEM: Dulbeco's modified-minimum

essential medium

DMSO: dimetil sulfóxido

DNA-PK: DNA-dependent Protein Kinase

DSB: double-strand breaks

\section{E}

EDTA: ethylenediamine-tetraacetic acid

ERK1/2: extracelular signal-regulated kinase

EST: expressed sequence tags

$\boldsymbol{F}$

FADD: fas-associated protein with death domain

FBS: Fetal Bovine Serum

FHA: forkhead associated

G

GST: Glutatión-S-Transferasa

H

H: Hora

H2AX: histona $2 A X$

$\mathrm{HA}$ : hemaglutinina

HR: homologous recombination

HtrA/Omi: high temperature requirement protein $A$ serine protease 2

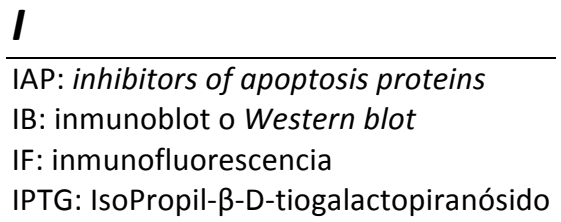

I

IAP: inhibitors of apoptosis proteins

IB: inmunoblot o Western blot

IPTG: IsoPropil- $\beta$-D-tiogalactopiranósido 


\section{J}

JIP1: JNK-Interaction protein 1

JNK: c-jun N-terminal kinase

\section{K}

Kb: kilobase

kDa: kilodalton

KSR1: Kinase Supressor of Ras 1

$L$

LB: medio "Luria Bertani"

\section{M}

$\mathrm{m} / \mathrm{v}$ : relación masa/volumen

M: molar

MAPK: mitogen-activated protein kinase

MCL-1: induced myeloid leukemia cell differentiation protein

MDC1: mediator of DNA damage checkpoint protein 1

mg: miligramo

min: minuto

$\mathrm{mL}$ : mililitro

$\mathrm{mm}$ : milímetro

$\mathrm{mM}$ : milimolar

MMR: mismatch repair

MOMP: mitochondrial outer membrane permeabilization

Mre11: meiotic recombination 11

MRN: complejo Mre-Rad50-NBS1

\section{N}

NBS: Nijmegen breakage syndrome NBSLD: Nijmegen breakage syndrome like disorder

NER: nucleotide excision repair

NHEJ: non-homologous end-joining

NLS: nuclear localization signal

$\mathrm{nm}$ : nanómetro

nM: nanomolar

NOXA/PMAIP-1: phorbol-12-myristate13 acetate induced protein 1

0

OMM: outer mitocondrial membrane
P

PARP: poly ADP ribose polymerase

PBS: phosphate buffer salinum

PCR: polymerase chain reaction

PIKK: phosphoinositide 3-kinase-related protein kinase

PMSF: phenyl methyl sulfonyl fluoride

PUMA: $p 53$ up-regulated modulator of apoptosis

PVDF: PolyVinyliDene Fluoride

\section{$\boldsymbol{R}$}

Ran: ras-related nuclear

RING: really interesting new gene

RNF8: ring finger 8

ROS: reactive oxygen species

rpm: revoluciones por minuto

RPMI: medio de cultivo, Roswell Park

Memorial Institute

$\mathrm{RT}$ : región transmembrana

RT-PCR: reverse transcriptase PCR

\section{$S$}

SDS: sodium dodecyl sulfate

SDS-PAGE: SDS-PolyAcrilamide Gel

Electrophoresis

Si-ARN: small-interference RNA

Smac/Diablo: second mitochondria

derived activator of caspases

SSB: single-strand breaks

$T$

TAE: Tris-Acetato-EDTA

TBS-T: Tris Buffer Salino con Tween-20

TNF: tumor necrosis factor

TRADD: TNF receptor type 1 associated death domain protein

$U$

Ub: ubiquitina

UV: radiación ultravioleta

V

$\mathrm{V}$ : voltio

VRK: vaccinia related kinase

$\mathrm{v} / \mathrm{v}$ : relación volumen/volumen 


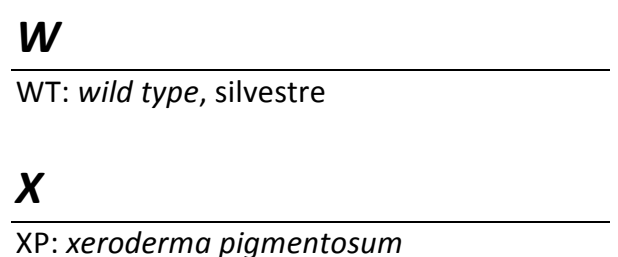

XP: xeroderma pigmentosum $\mu \mathrm{Ci}$ : microcurio

$\mu \mathrm{g}$ : microgramo

$\mu \mathrm{L}$ : microlitro

$\mu \mathrm{M}$ : micromolar

$\mu \mathrm{m}$ : micrómetro

${ }^{\circ} \mathrm{C}$ : grado centígrado

53BP1: p53-binding protein

\begin{tabular}{|ccc|}
\hline \multicolumn{4}{|c|}{ Aminoácidos } \\
\hline Abreviatura & Aminoácido \\
A & Ala & Alanina \\
C & Cys & Cisteína \\
D & Asp & Aspartato \\
E & Glu & Glutámico \\
F & Phe & Fenilalanina \\
G & Gly & Glicina \\
H & His & Histidina \\
I & lle & Isoleucina \\
K & Lys & Lisina \\
L & Leu & Leucina \\
M & Met & Metionina \\
N & Asn & Asparagina \\
P & Pro & Prolina \\
Q & Gln & Glutamina \\
R & Arg & Arginina \\
S & Ser & Serina \\
T & Thr & Treonina \\
V & Val & Valina \\
W & Trp & Triptófano \\
Y & Tyr & Tirosina \\
\hline
\end{tabular}

\section{Bases Nitrogenadas}

\begin{tabular}{|cl|}
\hline A & Adenina \\
$\mathbf{T}$ & Timidina \\
$\mathbf{G}$ & Guanina \\
$\mathbf{C}$ & Citosina \\
$\mathbf{U}$ & Uracilo \\
\hline
\end{tabular}

Tabla 1. Abreviaturas de aminoácidos y bases nitrogenadas. 


\section{ÍNDICE DE FIGURAS}

Figura 1. Tipos de daño sobre el ADN, mecanismos de reparación y consecuencias 8

Figura 2. Esquema de las proteínas que participan en la reparación de las roturas de doble cadena

Figura 3. Representación esquemática de los dominios más importantes de la quinasa ATM

11

13

Figura 4. Representación esquemática de la proteína Mre11

Figura 5. Representación esquemática de la proteína Rad50

Figura 6. Representación esquemática de NBS1

Figura 7. Representación esquemática del complejo Mre11-Rad50-NBS1

Figura 8. Representación esquemática de la proteína mediadora MDC1

Figura 9. Representación esquemática de la proteína mediadora 53BP1

Figura 10. Pasos para la formación del foco de reparación nuclear en respuesta a roturas de doble cadena del ADN

Figura 11. Modelo de ubiquitinación dependiente de RNF8 y RNF168

Figura 12. Principales vías de señalización de la apoptosis

Figura 13. Esquema de la estructura de la familia Bcl-2

Figura 14. Formación del poro mitocondrial por Bax y Bak

Figura 15. Unión de proteínas pro-apoptóticas sólo-BH3 a proteínas

anti-apoptóticas

Figura 16. Modelos de activación de Bax y Bak.

Figura 17. Representación esquemática del quinoma humano

Figura 18. Representación esquemática de la estructura de las quinasas VRK

Figura 19. Localización subcelular de la quinasa VRK1

Figura 20. Diagrama de VRK1 con sus principales sustratos

Figura 21. Localización subcelular de VRK2A y VRK2B

Figura 22. Sustratos de fosforilación de la quinasa VRK2

Figura 23. Funciones de la quinasa VRK2A en las rutas de señalización de MAPK

Figura 24. Esquema de proteínas que interaccionan con VRK2A y VRK2B

Figura 25. Localización subcelular de VRK1 en diferentes líneas celulares

Figura 26. Rápida activación de VRK1 en respuesta a radiación ionizante

Figura 27. Respuesta de VRK1 y cinética de formación de focos de 53BP1 en respuesta a radiación ionizante

Figura 28. Comparación de la señal de fluorescencia de VRK1 en ausencia de daño y tras tratamiento con doxorubicina y radiación ionizante

Figura 29. Efecto de la radiación ionizante sobre proteínas involucradas en la respuesta al daño del ADN

Figura 30. Efecto de diferentes dosis de radiación ionizante

Figura 31. Cinética de la formación de focos de yH2AX, NBS1, MDC1 y 53BP1

en respuesta a radiación ionizante con $3 \mathrm{~Gy}$ ( 
Figura 32. El silenciamiento de la quinasa humana VRK1 afecta la formación de focos de 53BP1 en respuesta a radiación ionizante

Figura 33. Localización de 53BP1 en focos inducidos por fármacos y efecto del silenciamiento de VRK1

Figura 34. La proteína mediadora del daño en el ADN MDC1 interacciona con la quinasa humana VRK1

Figura 35. El silenciamiento de VRK1 en células A549 no afecta los niveles de expresión de la proteína MDC1

Figura 36. El silenciamiento de la quinasa humana VRK1 no afecta la formación de los focos de MDC1

Figura 37. El silenciamiento de VRK1 afecta la formación de focos de 53BP1 pero no de MDC1 en respuesta al tratamiento con doxorubicina

Figura 38. El silenciamiento de VRK1 no afecta la formación de focos de MDC1 en respuesta a radiación ionizante

Figura 39. La proteína NBS1 del complejo MRN interacciona con la quinasa humana VRK1 independientemente del daño en el ADN

Figura 40. Validación de la interacción de NBS1 y VRK1

Figura 41. Interacción de NBS1 con los miembros de la familia VRK

Figura 42. Identificación de la zona de VRK1 que interacciona con NBS1

115

Figura 43. Interacción entre VRK1 K179E (quinasa inactiva) con NBS1

Figura 44. NBS1 es diana de fosforilación de VRK1

Figura 45. El silenciamiento de VRK1 disminuye los niveles de fosforilación de NBS1 en respuesta a radiación ionizante

Figura 46. NBS1 y VRK1 están interaccionando antes de la activación de NBS1 tras daño al ADN

Figura 47. ATM, NBS1 y VRK1 forman un complejo proteico

Figura 48. Alineamiento de las secuencias de NBS1 y los mutantes no fosforilables S343A y S432A

Figura 49. Los mutantes no fosforilables de NBS1 (S343A y S432A) interaccionan con la quinasa VRK1 silvestre y la quinasa VRK1 (R358X)

Figura 50. El silenciamiento de VRK1 afecta la formación de focos de NBS1 en respuesta a radiación ionizante

Figura 51. El silenciamiento de VRK1 afecta la formación de focos de NBS1 en células deficientes de ATM

Figura 52. El silenciamiento de VRK1 en células deficientes de ATM afecta la expresión de NBS1

Figura 53. La inhibición de la actividad de ATM y el silenciamiento de VRK1 no altera los niveles de expresión de NBS1 en células A549

Figura 54. Estabilidad proteica de NBS1 y VRK1 en células A549 y HT144

Figura 55. El silenciamiento de VRK1 no afecta la expresión génica de NBS1

Figura 56. Efecto del inhibidor del proteasoma MG132 sobre los niveles de NBS1 en células HT144 (ATM-/-) silenciadas para VRK1

Figura 57. El efecto del silenciamiento de VRK1 sobre los focos de NBS1 se revierte con el inhibidor del proteasoma MG132 
Figura 58. La ubiquitina-ligasa E3 RNF8 media la degradación de NBS1 en células deficientes de ATM

Figura 59. Ubiquitinación de NBS1

Figura 60. Interacción entre NBS1, RNF8 y VRK1

Figura 61. Localización subcelular y expresión de VRK2 en un panel de líneas celulares

Figura 62. Colocalización de la quinasa VRK2 con la proteína anti-apoptótica Bcl-xL y pro-apoptótica Bax

Figura 63. Interacción entre la quinasa VRK2A y las proteínas $B c l-x L, B c l 2$ o Bax

Figura 64. Interacción entre la quinasa VRK2A y las proteínas PUMA, Bad y Bnip3L

Figura 65. Efecto del silenciamiento de VRK2 sobre proteínas asociadas a la apoptosis

Figura 66. El silenciamiento de la expresión de VRK2 incrementa los niveles de ARNm de Bax pero no afecta los niveles de $\mathrm{Bcl}-2$ y $\mathrm{Bcl}-\mathrm{xL}$

Figura 67. El silenciamiento de la expresión de VRK2 incrementa la activación transcripcional del promotor de Bax-Luc

Figura 68. VRK2A inhibe la activación del promotor de Bax por Camptotecina

Figura 69. El silenciamiento de la expresión de VRK2 facilita la liberación del citocromo c y el procesamiento de PARP

Figura 70. El silenciamiento de la expresión de VRK2 sensibiliza las células a la camptotecina

Figura 71. Silenciamiento de la expresión de VRK2 facilita la activación de caspasas y por ende al procesamiento proteolítico de PARP en respuesta a camptotecina

Figura 72. El silenciamiento de la expresión de VRK2 ayuda a la inducción de daño en el ADN por camptotecina

Figura 73. Esquema de la participación de VRK1 en la formación de focos de reparación

Figura 74. Mecanismo propuesto para explicar la participación y modulación de VRK1 en la reparación de las roturas de doble cadena del ADN

Figura 75. Esquema de la participación de VRK1 en la formación de focos de reparación en ausencia de ATM

Figura 76. Modelo del posible mecanismo por el cual NBS1 está siendo

Figura 77. Mecanismos propuestos para la regulación negativa de Bax por VRK2A 


\section{ÍNDICE DE TABLAS}

Tabla 1. Abreviaturas de aminoácidos y bases nitrogenadas

Tabla 2. Alteración de proteínas de la respuesta al daño en el ADN y su relación con enfermedades humanas

Tabla 3. Información general de los oligonucleótidos utilizados

Tabla 4. Anticuerpos

Tabla 5. Información general de las líneas celulares

Tabla 6. Información general de los vectores recombinantes 


\section{INTRODUCCIÓN}





\section{DAÑO Y REPARACIÓN DEL ADN}

La homeostasis celular está regulada por el balance entre diferentes mecanismos como proliferación, senescencia y muerte celular. Uno de los mecanismos fundamentales para la supervivencia de la célula y el mantenimiento de la integridad y fidelidad del ADN es la respuesta al daño en el ADN o DDR (del inglés: DNA damage response). Aunque la integridad genómica es continuamente cambiada por las lesiones en el ADN (miles de lesiones espontáneas ocurren en cada célula diariamente) hacen que uno de los objetivos más importantes de este mecanismo evolutivamente muy conservado, sea la preservación de la información genética codificada en el ADN para ser transmitida de manera precisa a próximas generaciones celulares. El sistema DDR tiene como funciones principales la detección, señalización y reparación del ADN dañado.

La presencia de lesiones o roturas en el ADN provoca una rápida respuesta del sistema DDR, que conlleva a la coordinación de dos funciones principales: la primera, es la parada del ciclo celular con el fin de evitar la replicación del ADN dañado e impedir la propagación de información genética alterada a las células hijas; y la segunda, es la activación de la cascada de señalización adecuada, con el fin de mediar la reparación de los sitios lesionados para mantener la integridad del ADN. Si células en estado de proliferación sufren daño en el ADN, pero este es rápidamente reparado de manera adecuada, las células reanudan la proliferación normal, pero si en el caso contrario el daño recibido es muy severo y no puede ser reparado apropiadamente, se desencadenan señales que promueven la muerte celular programada o apoptosis. El sistema DDR también puede inducir la senescencia y la parada irreversible del ciclo celular. Esta respuesta depende del tipo celular y la intensidad, duración y naturaleza del daño recibido (d'Adda di Fagagna, 2008).

Las lesiones en el ADN pueden bloquear la replicación y transcripción, y si no son reparadas o son reparadas incorrectamente pueden llevar al origen de mutaciones que causan muerte celular, senescencia o inestabilidad genómica, la cual puede conducir a la tumorogénesis (Harper \& Elledge, 2007).

Los cambios en el ADN no siempre corresponden a mutaciones nocivas que desencadenan un crecimiento incontrolado o muerte celular, pues dependiendo de las circunstancias, una mutación se puede convertir en una ventaja para el organismo al permitir una mejor adaptación a los cambios externos.

\subsection{Tipos de daño}

Las lesiones en el ADN pueden ser causadas por diferentes tipos de daño, que pueden ser consecuencia de procesos celulares endógenos o producidos por agentes 
exógenos. A continuación se detallarán diferentes tipos de daño independientemente de su causa.

\subsubsection{Daño en el ADN por procesos celulares endógenos}

- Errores en la replicación: a pesar de la precisión con la que se lleva a cabo el proceso de replicación, la ADN polimerasa puede seleccionar incorrectamente el nucleótido para insertarlo en la cadena complementaria durante la replicación. Por lo tanto, la sustitución de un nucleótido por otro es una mutación puntual que constituye la forma más simple de daño en el ADN.

- Modificación de bases nitrogenadas por metilaciones: las metilaciones atípicas de las bases nitrogenadas producen miles de lesiones en el ADN por célula al día. Un ejemplo es la formación de un derivado metilado de la guanina $\left(0^{6}\right.$-metil-guanina). Esta base modificada puede generar una mutación post-replicativa ya que se puede aparear con la misma probabilidad con citosinas o timinas.

- Cambio entre bases nitrogenadas del ADN por desaminación: otro tipo de alteraciones que sufre el $A D N$ es la pérdida de grupos amino de sus bases nitrogenadas. Por ejemplo la desaminación de la 5-metil-citosina la convierte en timina, un nucleótido normal en el ADN. Por lo tanto, si este error no es reparado antes de la replicación del ADN, se podría formar una nueva cadena hija con una adenina en lugar de una guanina.

- Pérdida de bases nitrogenadas por depurinación o depirimidinación: la pérdida de purinas (adenina o guanina) o pirimidinas (timina o citosina) por la rotura del enlace glucosídico entre la base nitrogenada y el azúcar (desoxirribosa) genera un sitio llamado AP (apurínico o apirimidínico). Se pueden producir un promedio de 5.000 a 10.000 sitios AP por célula al día.

- Daño oxidativo en el ADN: el daño oxidativo es consecuencia del propio metabolismo celular y es causado por las especies reactivas de oxigeno ROS (del inglés: reactive oxygen species) como el anión superóxido $\left(\mathrm{O}_{2}\right)$, el peróxido de hidrógeno $\left(\mathrm{H}_{2} \mathrm{O}_{2}\right)$ y el radical hidroxilo $\left(\mathrm{OH}^{-}\right)$. Los radicales $\mathrm{OH}^{-}$actúan como fuertes oxidantes reaccionando con las bases nitrogenadas, provocando la rotura de una o ambas cadenas del ADN. Una de las principales alteraciones que originan los radicales libres es la transformación de la guanina en 8-dihidro-desoxiguanina (8oxo-G) que en la replicación del ADN puede aparearse normalmente con la citosina o anormalmente con la adenina, produciendo transversiones (GC a TA) en el ADN (Cooke et al, 2003; Hoeijmakers, 2009). Las especies reactivas de oxígeno y nitrógeno también pueden ser producidos por macrófagos y neutrófilos en los sitios de infección e inflamación (Kawanishi et al, 2006). 
Estos tipos de daños endógenos, pueden inducir un promedio de 100.000 lesiones por célula al día (Hoeijmakers, 2009).

\subsubsection{Daño en el ADN por agentes exógenos}

- Radiaciones ionizantes por rayos $\mathrm{X}$ y y (utilizados para tratamientos médicos 0 radioterapia): este tipo de daño genera radicales libres, a partir del agua presente en la célula, siendo el más importante el radical hidroxilo $\left(\mathrm{OH}^{-}\right)$. Estos radicales pueden inducir la oxidación de bases produciendo roturas de cadena simple o doble en el ADN (Ciccia \& Elledge, 2010).

- Radiación ultravioleta (UV): la capa de ozono absorbe la parte más peligrosa del espectro solar UV (UV C), pero los espectros residuales de UV A y UV B pueden inducir un promedio de 100.000 lesiones por célula expuesta en una hora (Jackson \& Bartek, 2009). El daño por radiación UV produce la unión covalente entre dos pirimidinas adyacentes del ADN (dimerización de pirimidinas: timina-timina, timinacitosina y citosina-citosina) lo que incrementa la probabilidad de que durante la replicación del $A D N$, la $A D N$ polimerasa inserte un nucleótido incorrecto en tal posición. La dimerización de pirimidinas también puede ocurrir entre diferentes cadenas del ADN, la cual impide la separación de las dos cadenas del ADN bloqueando la expresión del gen al detener su replicación.

\section{- Agentes químicos:}

a. agentes alquilantes que incluyen el metil metano-sulfonato (MMS), dietil sulfato (DES), diepoxi butano (DEB), N-metil-N-nitro-N-nitrosoguanidina (NTG), entre otros, originan bases alquiladas que conllevan a transversiones y deleciones.

b. El ácido nitroso $\left(\mathrm{HNO}_{2}\right)$ desamina la adenina a hipoxantina y la citosina a uracilo produciendo transversiones en el ADN. La hidroxilamina $\left(\mathrm{NH}_{2} \mathrm{OH}\right)$ reacciona con la citosina donde el grupo amino es reemplazado por un grupo hidroxilamino. Este derivado de la citosina se aparea con adenina produciéndose transiciones GC a TA.

c. Otros agentes químicos usados para el tratamiento del cáncer como la camptotecina y el etopósido, inhibidores de la topoisomerasa I y II respectivamente, inducen la formación de roturas de cadena sencilla o doble del ADN.

\subsection{Daño y reparación de cadena sencilla del ADN}

Como se ha mencionado anteriormente hay diferentes tipos de daño que pueden alterar la continuidad de una de las cadenas de la doble hélice del ADN produciendo roturas de cadena sencilla del ADN SSBs (del inglés: single-strand breaks). Al igual que cualquier otro tipo de daño celular que amenace la integridad del genoma, este 
debe ser detectado tempranamente y corregido con el fin de evitar mutagénesis, bloqueos en la replicación y transcripción, citotoxicidad o muerte celular. Cuando aparecen lesiones de tipo SSBs se puede utilizar la cadena complementaria como molde para reparar la cadena dañada. Además, existen diferentes mecanismos altamente conservados en la evolución encargados de reparar este tipo de lesiones (Figura 1, pág. 8), detallados a continuación:

\subsubsection{Mecanismos de reparación de la cadena sencilla del ADN}

- Reparación directa o in situ: en la mayoría de los casos el daño en el ADN es reparado mediante la eliminación de los nucleótidos o bases nitrogenadas seguida de la resíntesis de la región escindida. En este tipo de reparación participan enzimas encargadas de reparar directamente el daño. Los tipos de daño en el ADN que se pueden reparar a través de este mecanismo son pocos e incluyen la dimerización de pirimidinas por exposición a la luz UV o residuos alquilados de guanina que se forman de la adición de un grupo metilo o etilo en la posición $0^{6}$ del anillo de esta base nitrogenada. El mecanismo de reparación directa de los dímeros de pirimidina es la fotoreactivación, que utiliza la energía derivada de la luz visible para activar la enzima fotoliasa encargada de romper el anillo de ciclobutano que une a las pirimidinas.

- Reparación por escisión de bases BER (del inglés: Base Excision Repair): este mecanismo repara el daño en el ADN producido por ROS, metilación, desaminación y pérdida de nucleótidos formando sitios AP. La lesión es eliminada por una ADN glicosilasa que hidroliza el enlace glucosídico entre la base nitrogenada y la desoxirribosa, dejando un sitio apurínico/apirimidínico (AP) en el $A D N$. Posteriormente este sitio abásico o AP es eliminado por dos endonucleasas, que escinden en posiciones 3' (B-liasa) y 5' (AP endonucleasa). Por último se sustituye por el nucleótido adecuado gracias a la activad de la ADN polimerasa y ADN ligasa.

- Reparación por escisión de nucleótidos NER (del inglés: Nucleotide Excision Repair): repara daños que afectan a varios nucleótidos causando distorsiones estructurales en el ADN y obstaculizando la replicación como en el caso de las lesiones por UV que producen dimerización de pirimidinas. En este proceso intervienen endonucleasas que cortan entre 24 a 29 nucleótidos (en eucariotas) o 12-15 nucleótidos (en procariotas) alrededor de los nucleótidos afectados, eliminando así el segmento de ADN que contiene la lesión. EI ADN de la otra cadena permanece sin lesiones, así que la ADN polimerasa la utiliza como molde para sintetizar una nueva secuencia complementaria corta. Existen dos subvías de NER, el NER genómico global (GG-NER) y la reparación acoplada a la transcripción (TCR). Estas vías se diferencian en la forma de detectar el ADN dañado pero comparten el mismo proceso de reparación. El xeroderma pigmentosum, el síndrome de Cockayne 
y la tricotiodistrofia son síndromes asociados a defectos innatos en NER y se caracterizan por fotosensibilidad de las personas que las padecen. El xeroderma pigmentosum se origina por mutaciones en uno de los 7 genes XP (A-G); y las personas con este síndrome presentan un mayor riesgo de sufrir cáncer de piel puesto que sus células no son capaces de reparar el daño inducido por luz UV. El síndrome de Cockayne es causado por la mutación en los genes CSA o CSB y afecta la reparación acoplada a la transcripción. Las personas con este síndrome presentan falta de crecimiento, problemas en el desarrollo del sistema nervioso y envejecimiento prematuro. En cuanto a la tricotiodistrofia, está relacionada con mutaciones en los genes que codifican para las helicasas XPB y XPD; las personas con este síndrome presentan ictiosis de piel y retraso en el desarrollo físico y mental (Hoeijmakers, 2001).

En eucariotas, la distorsión en la estructura de la doble hélice producida por ejemplo, por la dimerización de pirimidinas, es detectada en GG-NER por el complejo XPC-HR23B. En el caso de TCR la ARN polimerasa queda bloqueada en el sitio de la lesión deteniendo la transcripción, el complejo CSA/CSB reconoce la ARN polimerasa bloqueada, la desplaza de la lesión y recluta las proteínas de reparación. A continuación la secuencia temporal para la reparación del daño es idéntica en las dos vías; tras la identificación del sitio dañado, las helicasas XPB (3`-5`) y XPD (5`-3`) del multicomponente factor basal de transcripción TFIIH abren la doble hélice en un promedio de 30 pares de bases alrededor de la lesión formándose una estructura similar a una burbuja. XPA confirma la presencia de la lesión y junto a la proteína de unión al ADN de cadena sencilla RPA estabilizan la apertura por unión a la cadena sin daño. Esta apertura en el ADN permite que las endonucleasas XPG y XPF/ERCC1 efectúen dos cortes $3^{\prime}$ y $5^{\prime}$, respectivamente, de la cadena dañada, liberando un fragmento de 24-29 nucleótidos que contiene la lesión. Posteriormente el sitio es reparado por la ADN polimerasa y sellado por la ADN ligasa (Hoeijmakers, 2001; Nouspikel, 2009).

- Reparación de apareamientos erróneos o reparación Mistmach MMR (del inglés: Mistmach Repair): este mecanismo, a diferencia de los demás actúa cuando la replicación ya se ha realizado y se encarga de corregir los nucleótidos que han quedado mal apareados por error de la ADN polimerasa, así como también de eliminar los pequeños bucles que se forman a partir de estos errores. Este proceso se basa en 3 pasos importantes: detección de la alteración (también llamada mismatch), escisión de la zona con la alteración y resíntesis de la zona afectada.

El complejo heterodimérico hMSH2/MSH6 (MutS $\alpha$ ) reconoce apareamientos erróneos y bucles pequeños en el ADN formados por 1 ó 2 nucleótidos, mientras que el complejo hMSH2/MSH3 (MutS $\beta$ ) reconoce bucles más grandes formados por más de 2 nucleótidos llamados loops de inserción/deleción (Jiricny, 2006). Otros 
complejos heterodiméricos como hMLH1/hPMS2 (hMutL $\alpha$ ) y hMLH1/hPMS1 (hMutL $\beta$ ) interactúan con los complejos MSH y factores de replicación para detectar y reparar el daño en el ADN. La escisión y resíntesis de la nueva cadena es llevada a cabo por diferentes proteínas como el antígeno nuclear de células en proliferación, la proteína de replicación $A$, el factor de replicación $C, A D N$ polimerasas Delta/Epsilon, exonucleasa I y endonucleasa FEN1. La deficiencia en el mecanismo de reparación Mismatch está relacionada con la aparición de cáncer colorrectal no polipósico hereditario y algunos de tipo esporádico.
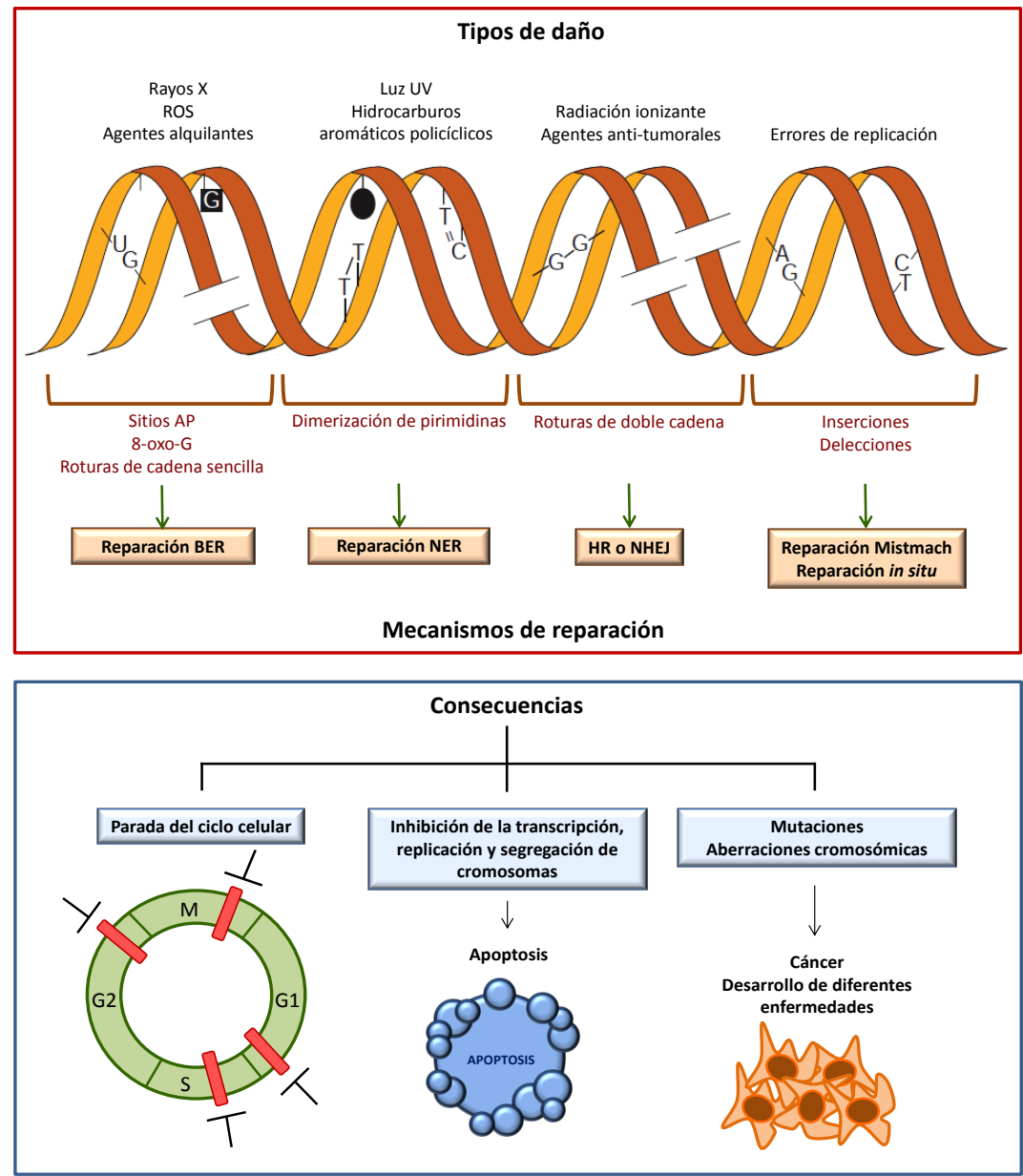

Figura 1. Tipos de daño sobre el ADN, mecanismos de reparación y consecuencias. Ejemplos de diferentes tipos de daños endógenos y exógenos sobre el ADN y sus correspondientes mecanismos de reparación responsables de corregir estas lesiones. En el panel inferior se muestra las consecuencias producidas por las lesiones en el ADN, la parada del ciclo celular le da una oportunidad a la célula de reparar el ADN dañado. Sin embargo, si el daño es muy fuerte y el $A D N$ no puede ser reparado, la célula entrará en apoptosis. Una incorrecta reparación del ADN y la inestabilidad genómica puede llegar a desencadenar tumorogénesis. Adaptado de (Hoeijmakers, 2001). 


\subsection{Daño y reparación de la doble cadena del ADN}

La integridad del ADN puede ser afectada por factores externos (luz UV, radiación ionizante y agentes químicos) o factores endógenos (consecuencia del propio metabolismo), donde destacan aquellos que pueden provocar uno de los daños más letales para la célula: la rotura de la doble cadena del ADN DSBs (del inglés: DNA double-strand breaks) (Jackson, 2002). Las DSBs pueden ser generadas naturalmente cuando las horquillas de replicación se encuentran con una rotura de cadena sencilla, por el propio metabolismo celular que produce ROS afectando las cadenas del ADN, y también por el metabolismo deficiente de los telómeros (Riha et al, 2006). Uno de los procesos biológicos mejor caracterizados que produce DSBs es la recombinación $V(D) J$ llevada a cabo en linfocitos $T$ y $B$ con el fin de generar una diversidad de receptores de linfocitos $T$ y de inmunoglobulinas para el reconocimiento de diferentes antígenos (Chaudhuri et al, 2007; Jackson, 2002). También, en el proceso de meiosis las células tienen la capacidad de provocar DSBs de manera controlada para la recombinación de cromosomas homólogos (Cole et al, 2010; Neale et al, 2005).

Las DSBs pueden ser producidas por radiación ionizante IR (del inglés: ionizing radiation), a través de la producción de ROS (Leadon, 1996; Lieber et al, 2003) y drogas radiomiméticas utilizadas en quimioterapia que bloquean la actividad de la topoisomerasa I induciendo roturas de cadena sencilla que se transforman en DSBs al quedar atrapado el complejo de escisión (topoisomerasa-ADN) dentro de la horquilla de replicación, o inhibiendo la actividad de la topoisomerasa II que produce DSBs que puede llevar a aberraciones cromosómicas (Huang et al, 2003; Shrivastav et al, 2008).

Las DSBs son más difíciles de reparar puesto que no se puede utilizar la cadena complementaria del ADN como molde en la replicación. Además, una deficiente reparación puede dar lugar a alteraciones genéticas que incluyen deleciones, translocaciones, fusiones cromosómicas, entre otras. Este tipo de aberraciones cromosómicas pueden afectar a muchos genes simultáneamente, alterando la estabilidad genómica, lo que podría favorecer la carcinogénesis. Las células disponen de dos vías principales para la reparación de este tipo de daño: la primera es la recombinación homóloga HR (del inglés: homologous recombination), donde la secuencia de nucleótidos se intercambia entre segmentos homólogos; y la segunda, la reparación por unión de los extremos no homólogos NHEJ (del inglés: nonhomologous end-joining) que se encarga de la unión de los extremos generados tras la rotura de la doble cadena del ADN, sin necesidad de usar un molde (Ferguson \& Alt, 2001). 
Para la detección, señalización y reparación del daño en el ADN participan una gran variedad de proteínas que se encuentran altamente conservadas a través de la evolución. En la respuesta al daño en la doble cadena del ADN participan las siguientes proteínas: proteínas sensoras (H2AX, MRN, PIKKs (ATM,ATR,DNA-PKcs)), encargadas de detectar el sitio donde se ha producido el daño; proteínas mediadoras (MDC1, 53BP1, BRCA1), las cuáles funcionan como proteínas adaptadoras ayudando a reclutar diferentes miembros de la respuesta al daño en el ADN (DDR); las proteínas transductoras (PIKKs, Chk1 y Chk2), que ayudan a amplificar la señal y por último las proteínas efectoras (p53, cdc25), encargadas de desencadenar la respuesta adecuada como parada de ciclo celular, reparación, senescencia o apoptosis (Figura 2) (Thompson, 2012).

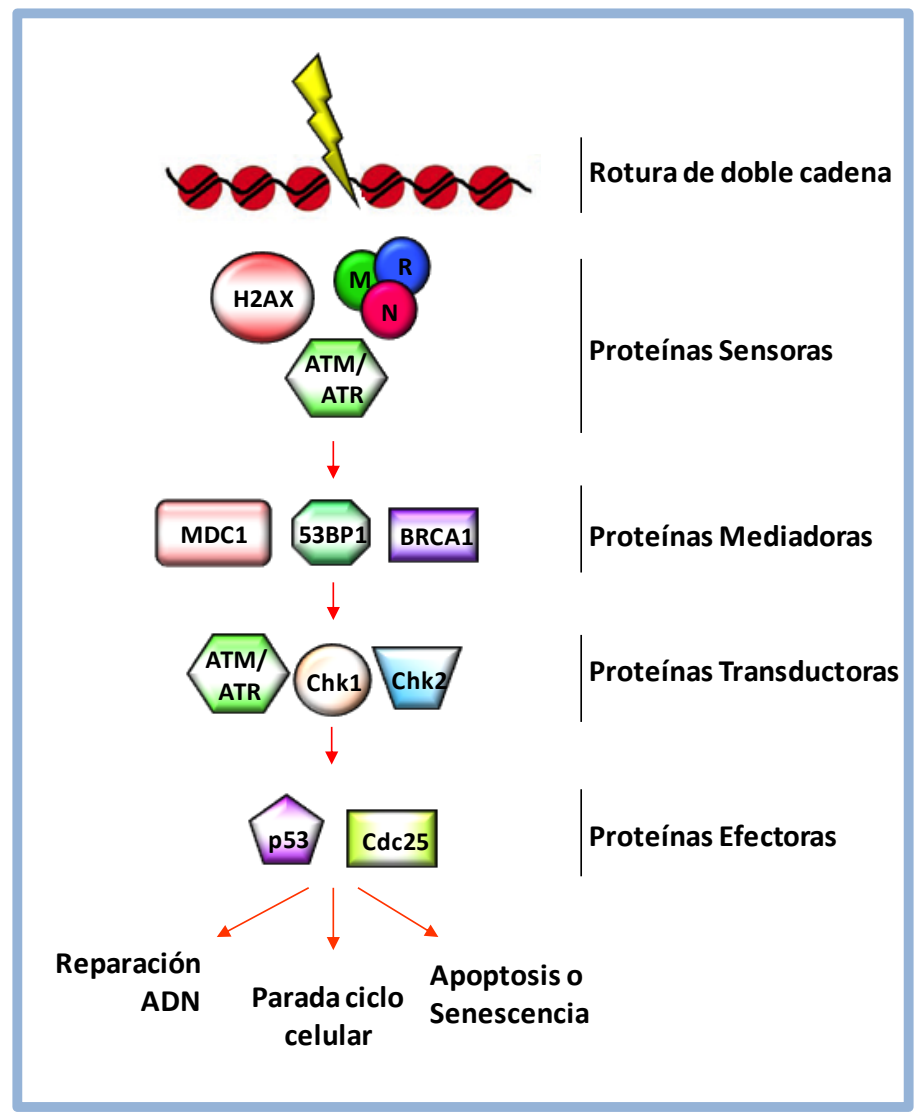

Figura 2. Esquema de las proteínas que participan en la reparación de las roturas de doble cadena. El daño es detectado por las proteínas sensores, la señal es transmitida a las proteínas transductoras a través de las proteínas mediadoras. Las quinasas transductoras fosforilan las proteínas efectoras encargadas de desencadenar la respuesta adecuada. 


\subsubsection{Detección de DSBs y activación de las proteínas sensoras}

El resultado de las DSBs es la descondensación y el cambio en la estructura de la cromatina, importantes para la activación de la respuesta al daño en el ADN (DDR), seguida del reconocimiento de los extremos finales de la doble cadena por proteínas sensoras (Kumar et al, 2012).

Un componente principal en la cascada de señalización en respuesta a DSBs es la proteína quinasa ATM, que juega un papel central cooperando con la coordinación e integración de diferentes señales con el fin de reparar correctamente el daño producido en el ADN (Lavin, 2008). La proteína ATM es una serina - treonina quinasa, miembro de la familia de quinasas relacionadas con fosfoinosítido-3quinasa PIKK (del inglés: phosphoinositide 3-kinase-related protein kinase). La deficiencia de ATM causada por mutaciones en el gen que codifica para esta proteína (localizado en el cromosoma 11q22-23), produce el síndrome neurodegenerativo ataxia talangiectasia (A-T). Este síndrome se caracteriza por ser un desorden autosómico recesivo con ataxia cerebelar progresiva, radiosensibilidad, inestabilidad genómica y alta predisposición al cáncer (Derheimer \& Kastan, 2010).

ATM es una proteína nuclear de 350 kDa formada por 3056 aminoácidos (aa) (Figura $3)$. Se encuentra como dímero inactivo en condiciones normales y tras producirse daño en el ADN se desencadenan diferentes procesos que conducen a su activación. En primer lugar, se produce la relajación de la cromatina, seguida de la monomerización de ATM y con ello la activación de dicha quinasa. Este proceso es facilitado por la autofosforilación en los residuos serina 367, serina 1893 y serina 1981 y por la acetilación de la lisina 3016 mediada por la acetilasa Tip60. Por último, para completar los eventos necesarios para su total activación, el complejo MRN (Mre11-Rad50-NBS1) recluta a ATM a los sitios de la lesión (Kozlov et al, 2011; Lee \& Paull, 2007; Sun et al, 2007).

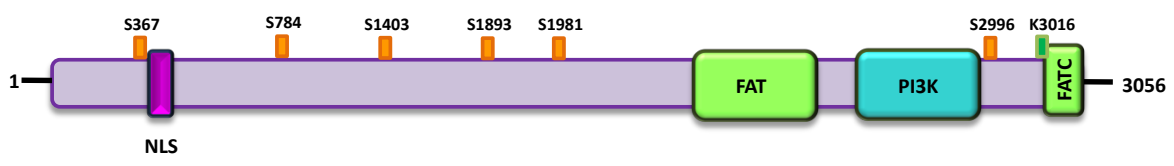

Figura 3. Representación esquemática de los dominios más importantes de la quinasa ATM. Se indican los residuos de serina y lisina importantes para la completa activación de esta proteína. La región $\mathrm{N}$-terminal de ATM es importante para la interacción con diferentes sustratos entre ellos se encuentran p53, NBS1 y BRCA1. 
Otros miembros de la familia PIKK son: la proteína relacionada con ataxia talangiectasia y Rad3 ATR (del inglés: ataxia-telangiectasia and Rad3 related protein kinase), la subunidad catalítica de la proteína quinasa dependiente de ADN DNAPKcs (del Inglés: DNA dependent protein kinase catalytic subunit), la diana de rapamicina en células de mamífero mTOR (del inglés: mammalian target of rapamycin) y hSMG1. Los miembros de esta familia se caracterizan por tener alto peso molecular (entre 260 y $470 \mathrm{kDa}$ ), son poco convencionales y tienen motivos típicos de la quinasa lipídica PI3K (Abraham, 2004).

Tanto ATM como DNA-PKcs detectan las roturas de doble cadena en el ADN. La diferencia entre ellas radica en que las DNA-PKcs juegan un papel importante en la reparación de la doble cadena del ADN mediante el mecanismo de reparación NHEJ, mientras que ATM principalmente detecta y transduce el daño en la HR. En cuanto a ATR, esta proteína interviene en la detección y transducción de la señal a partir de paradas de replicación debidas a bloqueos en la horquilla de replicación o lesiones producidas por la dimerización de pirimidinas causadas por la luz UV y roturas de una sola cadena del ADN. El reclutamiento de estas proteínas a los sitios de lesión es mediado en el caso de ATM por el complejo Mre-Rad50-NBS1, en el caso de ATR por la proteína de interacción de ATR, ATRIP (del inglés: ATR-interacting protein) y para las DNA-PKcs por el heterodímero Ku70/Ku80 (Falck et al, 2005). ATM, ATR y DNAPKcs fosforilan gran variedad de sustratos en serina o treonina seguidos de glutamina (SQ / TQ) (Kurz \& Lees-Miller, 2004), que transducen la señal con el fin de iniciar la reparación del daño y si este no puede ser reparado, activar la apoptosis (Czornak et al, 2008).

\subsubsection{El complejo MRN (Mre11-Rad50-NBS1) actúa como sensor de las DSBs}

El complejo MRN es importante para el reconocimiento de las DSBs y para la reparación del daño en el ADN mediante su participación en las dos vías de reparación HR y NHEJ (Kozlov et al, 2011; Xie et al, 2009). Este complejo proteico altamente conservado, además de estar relacionado con la reparación del ADN, también está involucrado en diferentes funciones como replicación del ADN, mantenimiento de los telómeros y señalización en los puntos de control durante el ciclo celular (Czornak et al, 2008; van den Bosch et al, 2003).

La proteína de recombinación meiótica Mre11 (del inglés: meiotic recombination 11) está formada por 708 aa y pesa $81 \mathrm{kDa}$. Tiene un dominio nucleasa amino-terminal (N-terminal) y dos motivos de unión al ADN, uno en la región central y otro en la región carboxi-terminal (C-terminal) (Stracker \& Petrini, 2011). En esta región se encuentra el dominio GAR (repeticiones glicina - arginina), el cuál regula la actividad 3'-5' exonucleasa de Mre11. En esta misma región se encuentra el dominio de unión a Rad50. La región $\mathrm{N}$-terminal de Mre11 es importante para la interacción con la 
región C-terminal (entre los aminoácidos 673-699) de NBS1 y para su localización nuclear (Figura 4) (Desai-Mehta et al, 2001). En esta misma región se encuentran los motivos de dimerización, los cuales ayudan a unir dos moléculas de Mre11 en forma de U. Esta formación homodimérica es necesaria para una correcta unión al ADN, así como para la función básica del complejo MRN (Williams et al, 2008). La actividad nucleasa de Mre11 es dependiente de ATP, manganeso, la presencia de NBS1 y la estimulación por parte de Rad50 (Rupnik et al, 2010). Mutaciones en el gen Mre11 (11q21) producen el desorden similar a la ataxia-telangiectasia ATLD (del inglés: ataxia-talangiectasia like disorder), en el cual se presenta radiosensibilidad, ataxia cerebelar, aberraciones cromosómicas, y no está asociada a deficiencia inmunitaria (Taylor et al, 2004).

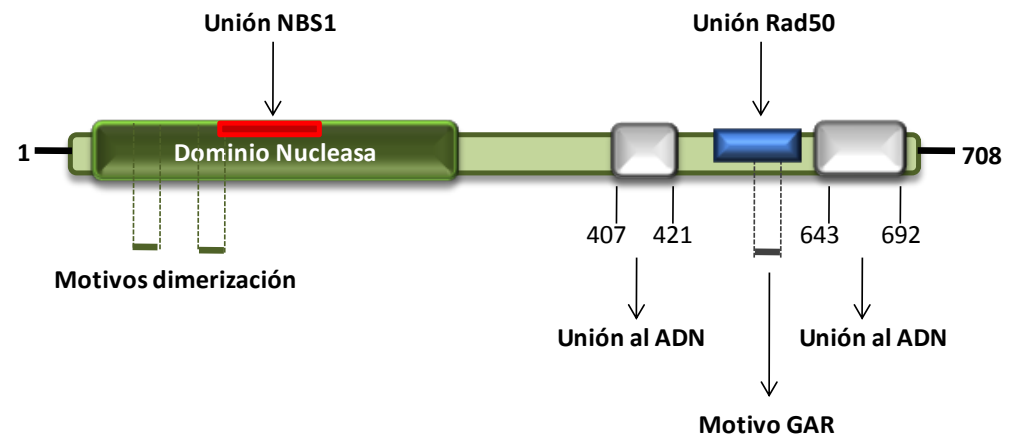

Figura 4. Representación esquemática de la proteína Mre11. En la región N-terminal se encuentra el sitio de unión a NBS1 y el dominio nucleasa. Por otro lado, a través de la región C-terminal se une a Rad50 y al ADN.

Rad50 es uno de los miembros de la familia encargada del mantenimiento estructural de los cromosomas SMC (del inglés: structural maintenance of chromosome), y forma parte de las condensinas que participan en el ensamblaje y la organización del ADN dentro de los cromosomas y las cohesinas que organizan y unen el ADN entre cromátidas hermanas (Kinoshita et al, 2009). La proteína Rad50 está formada por 1312 aa y tiene un peso molecular de 153 kDa. Se caracteriza por tener una larga región en forma de cola en espiral "coiled-coil", donde la región Nterminal y C-terminal se asocian de forma antiparalela separando las cabezas globulares formadas por los motivos Walker A y Walker B importantes para la unión a nucleótidos y por sus dominios ATPasa (van der Linden et al, 2009). A cada lado de los dominios Walker, se encuentran las regiones de unión a Mre11 (Hopfner et al, 2002). En el centro de la región "coiled-coil" se encuentra un motivo conservado de CXXC (Cys-X-X-Cys), también llamado dominio gancho (hook), a través del cual se pueden unir 2 proteínas de Rad50 (homodimerización) de manera dependiente de 
zinc (Figura 5) (Lamarche et al, 2010; Stracker \& Petrini, 2011). Mutaciones en el gen Rad50 (cromosoma 5q31.1) producen el desorden similar al síndrome de rotura Nijmegen NBSLD (del inglés: NBS-like disorder) en el cual los individuos presentan sensibilidad a la irradiación, inestabilidad cromosómica, microcefalia y retardo en el crecimiento. No se observa inmunodeficiencia (Czornak et al, 2008; Waltes et al, 2009), pero incrementa la susceptibilidad al desarrollo de diferentes tipos de cáncer, entre ellos cáncer de mama y ovario (Heikkinen et al, 2003).

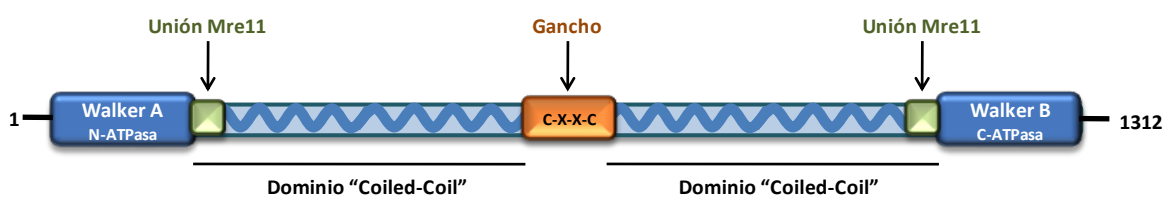

Figura 5. Representación esquemática de la proteína Rad50. Se observa los dominios Walker A y B separados por una región central en espiral llamado dominio "coiled-coil". A cada lado de los dominios Walker se encuentran las regiones de interacción con la proteína Mre11. En el centro de la proteína se encuentra el dominio gancho o hook importante para la dimerización y flexibilidad proteica.

NBS1, también conocido como nibrina o p95, es una proteína nuclear de 754 aa codifcada por el gen NBS localizado en el cromosoma 8q2.1. Mutaciones en este gen conllevan al desarrollo del síndrome de rotura Nijmegen NBS (del inglés: nijmegen breakage syndrome) (Zhang et al, 2006). Este desorden autosómico recesivo se caracteriza por alta sensibilidad a radiación ionizante, microcefalia, retraso en el crecimiento, alteraciones como cara de pájaro, clinodactilia, sindactilia, inmunodeficiencia (deficiencia de IgG y IgA, bajos niveles de células CD3+ y CD4+) y alta incidencia de aparición de cáncer, predominando leucemias y linfomas (Czornak et al, 2008; Tauchi et al, 2002). La mutación más frecuente en los pacientes con NBS, que tiene lugar en el $90 \%$ de los casos, es la deleción de 5 nucleótidos (ACAAA) en el exón 6 del gen, más frecuentemente llamada 657del5, que origina la formación de dos proteínas truncadas, una con la región $\mathrm{N}$-terminal con un peso molecular de 26 kDa y otra con la región C-terminal con $70 \mathrm{kDa}$. Estas proteínas truncadas mantienen parcialmente la función celular (Difilippantonio et al, 2007; Difilippantonio \& Nussenzweig, 2007; Tauchi et al, 2002).

La proteína NBS1 no tiene actividad enzimática y regula las funciones del complejo MRN. Esta proteína se encuentra dividida en 3 regiones funcionales. La primera es la región $\mathrm{N}$-terminal en la cual se encuentra el dominio FHA (del inglés: forkheadassociated) y dos dominios adyacentes de BRCT (del inglés: breast cancer associated 1 C terminus). El dominio FHA se une a residuos fosforilados de treonina que se encuentran en motivos S-X-T de algunas proteínas que participan en el daño del ADN 
(MDC1 y Ctp1). Los dominios BRCT también se unen a motivos $\mathrm{S}-\mathrm{X}-\mathrm{T}$, pero cuando los residuos fosforilados son serinas. Estas interacciones fosfo-dependientes son importantes para el reclutamiento de proteínas a los sitios del ADN dañado (Lloyd et al, 2009). Los dominios FHA y BRCT también son importantes para la acumulación del complejo MRN en los focos inducidos por irradiación (Cerosaletti \& Concannon, 2003) y para la unión a la histona H2AX fosforilada (Kobayashi et al, 2004). La segunda región corresponde a la región central de NBS1 donde se encuentran varios motivos SQ, siendo en particular los residuos serina 278 y serina 343 fosforilados por la quinasa ATM en respuesta al daño en el ADN. Por último, la tercera región, corresponde al extremo C-terminal que tiene el dominio de interacción con Mre11 y el dominio por el cual interacciona y recluta a ATM (Figura 6) (Lamarche et al, 2010). En esta región también se encuentran 3 señales de localización nuclear entre los aminoácidos 461-467, 590-594 y 751-754.

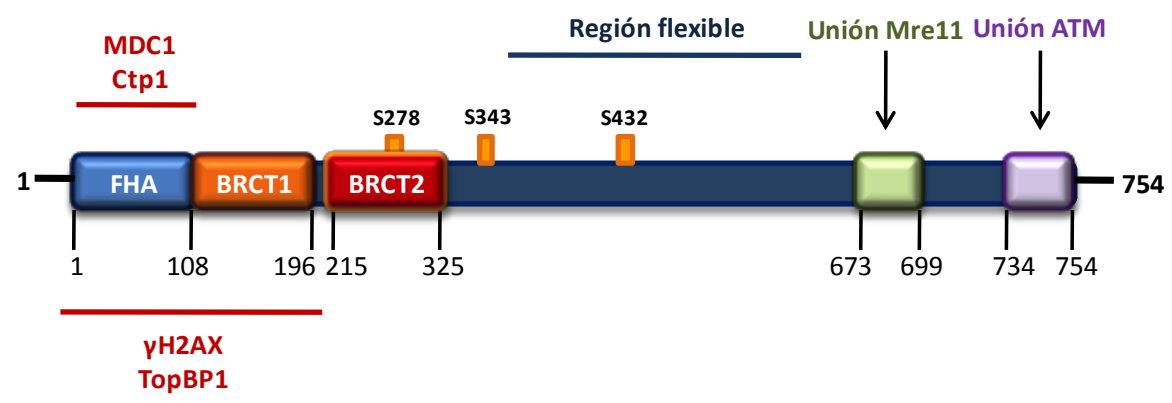

Figura 6. Representación esquemática de NBS1. En la región amino terminal se encuentra el dominio (FHA), seguido de dos dominios en tándem BRCT importantes para la interacción con residuos fosforilados de diferentes proteínas como MDC1 y $\mathrm{YH} 2 \mathrm{AX}$, entre otras. En la región carboxi terminal se encuentran los motivos responsables de la interacción con proteínas como Mre11 y ATM. Se muestra también los residuos de fosforilación más importantes de NBS1 en respuesta al daño en el ADN.

El complejo MRN tiene tres funciones principales: a) unión al ADN, b) enlazar el ADN comportándose como un puente en distancias largas y cortas y c) la activación de las rutas de señalización para la parada del ciclo celular y la reparación del ADN (Williams et al, 2010). El complejo MRN (Figura 7) está formado por dos subunidades de Mre11 con actividad exonucleasa, que interaccionan con las regiones "coiled-coil" cerca de los dominios ATPasa de dos Rad50 $\left(\mathrm{M}_{2} \mathrm{R}_{2}\right)$ formando así un heterotetrámero (van der Linden et al, 2009). Mre11 y Rad50 forman la cabeza del complejo MRN con actividad nucleasa regulada por ATP que detecta y se une a las DSBs. También puede enlazar dos moléculas de ADN separadas mediante los dominios "coiled-coil" de Rad50 (Schiller et al, 2012). Además, dos moléculas de NBS1 se unen para completar 
el heterohexámero, de modo que NBS1 actúa como proteína adaptadora muy flexible, gracias a la cual tiene lugar la interacción con varias proteínas como H2AX y ATM, desencadenando la cascada de señalización para la reparación de las DSBs. NBS1 también es esencial para mantener el complejo MRN en el núcleo, y actúa en conjunto con la ATPasa Rad50 controlando la actividad nucleasa de Mre11 (Williams et al, 2010).

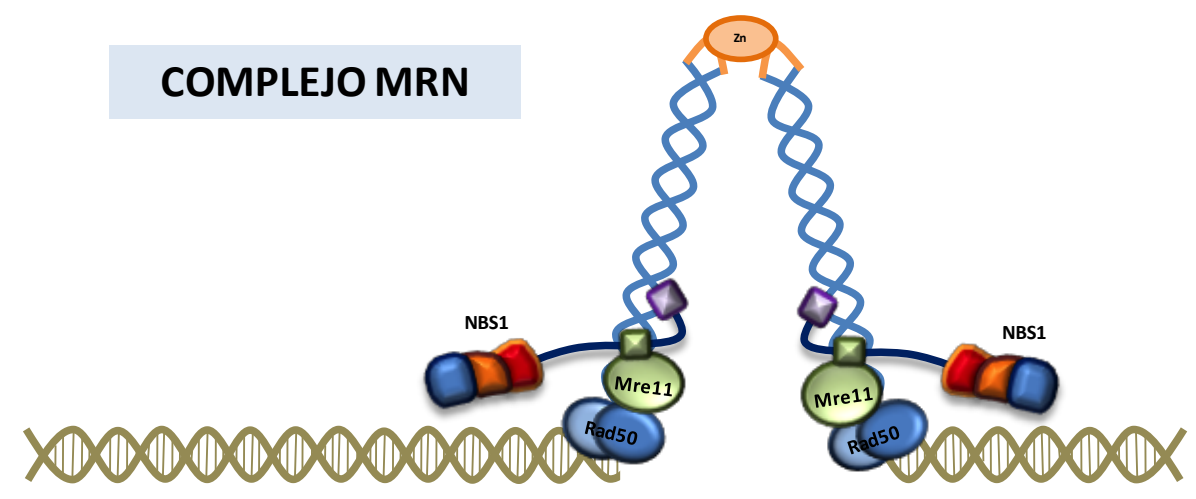

Figura 7. Representación esquemática del complejo Mre11-Rad50-NBS1. El complejo MRN consta de un heterohexámero formado por la "cabeza" constituida por 2 moléculas de Mre11 y 2 moléculas de Rad50. Además, tiene 2 moléculas de NBS1, la cual es una proteína adaptadora esencial para la interacción con otras proteínas, mediando la activación y el desarrollo de la ruta de señalización en respuesta al daño en el ADN.

El complejo MRN es uno de los primeros en unirse a las roturas de doble cadena en el ADN de manera independiente de ATM (Lavin, 2007; Mirzoeva \& Petrini, 2003). Esta unión tiene lugar a través de la nucleasa dependiente de $\mathrm{Mn}^{2+} \mathrm{Mre11}$ y la ATPasa Rad50, que se unen a los extremos dañados del ADN. ATM, al igual que el complejo MRN, es reclutada rápidamente a los sitios lesionados. Inicialmente ATM se une directamente al ADN y luego se asocia al complejo MRN a través de NBS1. De esta forma ATM es activado completamente, además de quedar retenido en los focos de respuesta al daño (Uziel et al, 2003). ATM fosforila a NBS1 en los residuos serina 278 y 343, lo cual contribuye a la activación de otras proteínas involucradas en esta ruta de señalización, así como también da lugar a una retroalimentación positiva que mantiene la actividad de ATM (Lee \& Paull, 2005; Lim et al, 2000; Shiloh \& Ziv, 2013; Wen et al, 2013).

ATM tiene un papel muy importante en la respuesta a DSBs, se puede detectar esta proteína en los focos un minuto después del daño al ADN y persistir durante más de 4 horas. ATM activado fosforila una gran variedad de sustratos entre ellos NBS1 
como se ha indicado anteriormente, Mre11, H2AX, MDC1, BRCA1, SMC1, CHK2, p53, Artemis y DNA-PKcs (Matsuoka et al, 2007).

\subsubsection{Papel de $\mathrm{YH}$ 2AX y reclutamiento de las proteínas mediadoras MDC1, 53BP1 y BRCA1}

Las roturas de DSBs son detectadas por el complejo MRN y ATM es reclutado a los sitios de la lesión mediante su interacción con la región C-terminal de NBS1. En respuesta a las DSBs, la histona $\mathrm{H} 2 \mathrm{~A}$, concretamente la variante $\mathrm{H} 2 \mathrm{AX}$, es rápidamente fosforilada en el residuo serina $139(\gamma \mathrm{H} 2 \mathrm{AX})$ por la quinasa ATM activada, formando focos discretos en los sitios del ADN lesionado (Burma et al, 2001; Stiff et al, 2004). La fosforilación de esta histona es un paso esencial para la respuesta al daño en el ADN ya que sirve como señal de localización del daño (marcador epigenético) y por lo tanto ubica el lugar donde será ensamblado el foco de reparación (Bekker-Jensen \& Mailand, 2010). Posteriormente, la $\mathrm{yH} 2 \mathrm{AX}$ (denominación de la histona fosforilada) es reconocida por MDC1 (del inglés: mediator of DNA damage checkpoint protein 1). Esta interacción protege a $\mathrm{\gamma H} 2 \mathrm{AX}$ de la acción de fosfatasas como PP2A o PP4.

MDC1 es una proteína nuclear de 226 kDa formada por 2089 aa. Tiene dos dominios en tándem de BRCT en la región C-terminal que se unen selectivamente a residuos de serina fosforilados. A través de estos dominios MDC1 se une a la histona H2AX fosforilada en el residuo serina 139 al reconocer la secuencia (pS-Q-E-Y-COOH) ubicada en la región C-terminal. Estos dominios también interaccionan con las proteínas 53BP1, p53, Mdm2, entre otras. En la región central de MDC1 se encuentra un dominio repetitivo rico en prolina/serina/treonina (PST), por el cual interacciona con la proteína DNA-PK. Existe poca información sobre las funciones de este dominio pero se sabe que no afecta el relutamiento de MDC1 a los focos de reparación (Jungmichel \& Stucki, 2010). La región $\mathrm{N}$-terminal contiene más de 20 motivos S/TQ que pueden ser fosforilados por ATM de manera dependiente del complejo MRN (Stewart et al, 2003). Particularmente, en esta región se encuentra un grupo de 4 motivos TQ seguidos por una fenilalanina llamados TQXF. Después de la unión de MDC1 a $\mathrm{\gamma H} 2 \mathrm{AX}$, ATM fosforila estos motivos TQXF, esta fosforilación es importante para el reclutamiento de la ubiquitin-ligasa RNF8 (Kolas et al, 2007). En esta misma región se encuentra una segunda sección repetitiva formada por 6 motivos de residuos de serina y treonina separados por un aspartato, llamada región SDT, por la cual interacciona con la proteína NBS1 del complejo MRN de forma dependiente de fosforilación (Chapman \& Jackson, 2008). La fosforilación de ambos residuos serina y treonina de estos motivos son necesarios para la unión a NBS1, siendo reconocidos y fosforilados por la quinasa CK2 (del inglés: casein kinase 2) (Coster \& Goldberg, 2010). Por último, en la región N-terminal también se encuentra el dominio FHA, importante para la interacción entre proteínas mediante el 
reconocimiento de residuos fosforilados de treonina encontrados en los motivos (pT-Q-E-L) (Figura 8) (Durocher et al, 2000; Stucki \& Jackson, 2004). Una de las proteínas que interacciona con este dominio es la proteína CHK2 fosforilada en la treonina 68, aunque esta interacción es transitoria y rápida. Otra proteína que interacciona con el dominio FHA de MDC1 es la quinasa ATM, aunque esta interacción requiere la fosforilación previa de ATM en el residuo serina 1981 (Coster \& Goldberg, 2010).

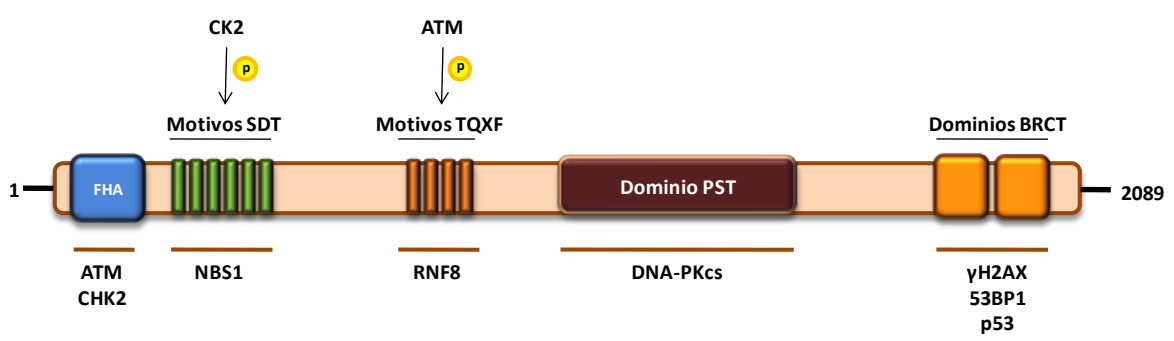

Figura 8. Representación esquemática de la proteína mediadora MDC1. Los dominios FHA y BRCT, median las interacciones con residuos fosforilados de diferentes proteínas. Los motivos SDT (verde) fosforilados son importantes para la interacción con la proteína NBS1. Así mismo, los motivos TQXF (naranja) fosforilados por ATM median la interacción con la proteína RNF8. Cada uno de los dominios y regiones son importantes para el correcto desarrollo de la respuesta a las lesiones del ADN. En la parte inferior de la gráfica se indica las proteínas y su respectiva región de interacción con MDC1. Adaptado de (Jungmichel \& Stucki, 2010).

El reclutamiento de MDC1 conlleva a una mayor acumulación del complejo MRN (por interacción directa de MDC1 y NBS1), amplificando la actividad local de ATM y expandiendo la cantidad de $\mathrm{\gamma H} 2 \mathrm{AX}$ a lo largo de la cromatina (Tobias et al, 2013). La propagación de $\mathrm{\gamma H} 2 \mathrm{AX}$ cientos de kilobases lejos del sitio de lesión atrae y retiene gran número de proteínas que participan en la DDR. De esta forma la acumulación de estas proteínas y las múltiples copias que se encuentran de ellas forman los focos de reparación nucleares, cuyo tamaño puede variar entre los 0.6 y $1.6 \mu \mathrm{m}$, creciendo a medida que transcurre el tiempo (Yamauchi et al, 2008).

Otra de las modificaciones importantes en la histona H2AX es la defosforilación de la tirosina 142. En condiciones normales este residuo ubicado en la región C-terminal de la histona H2AX se encuentra fosforilado por acción de la quinasa WSTF (una subunidad del complejo de remodelación de la cromatina WICH) (Xiao et al, 2009). Este residuo se sitúa en el motivo que reconoce los dominios BRCT de MDC1, y su fosforilación, bloquea la unión de MDC1 a pH2AX. Después de producirse el daño en el ADN, la tirosina 142 de la histona H2AX es defosforilada por la fosfatasa EYA 1/3, 
lo cual conlleva a la unión de MDC1 y al reclutamiento de proteínas al foco de reparación (Cook et al, 2009).

Entre las proteínas reclutadas al foco de reparación se encuentra la ubiquitina ligasa RNF8, que se asocia a los motivos TQXF de MDC1, previamente fosforilada por ATM. La histona H2AX también es ubiquitinada en la lisina 119 por esta ubiquitina ligasa ayudando al reclutamiento de las proteínas mediadoras 53BP1 y BRCA1, ambas también fosforiladas por ATM. La localización de RNF8 en los sitios de lesión depende de su dominio FHA, mientras que su dominio dedo RING (del inglés: really interesting new gene) es importante para el reclutamiento de 53BP1 y BRCA1.

Las modificaciones en las histonas (Costelloe et al, 2006), así como el reclutamiento de MDC1, conducen a la acumulación de las proteínas mediadoras 53BP1 (del inglés: p53-Binding Protein) y BRCA1 (del inglés: breast cancer associated 1) en los sitios del ADN dañado. Estas proteínas no tienen actividad enzimática y la función principal de ambas es facilitar la señalización entre las proteínas sensoras del daño y las proteínas transductoras. Inicialmente 53BP1 fue identificada como una proteína que interacciona con p53, estimulando su actividad (Iwabuchi et al, 1994). Posteriormente se demostró su localización en las DSBs después de IR o tratamiento con drogas radiomiméticas (Anderson et al, 2001). 53BP1, al igual que MDC1, presenta dos dominios consecutivos BRCT en su región C-terminal, seguidos por dos dominios tudor en tándem importantes para su localización en las DSBs (Figura 9, pág. siguiente). Tras el daño al ADN, los dominios tudor interaccionan con la lisina 79 metilada de la histona H3 (Huyen et al, 2004) y la lisina 20 dimetilada de la histona H4 (Botuyan et al, 2006). Estas modificaciones se encuentran en el centro de la histona en condiciones normales. Después del daño, se produce un cambio conformacional que expone dichos residuos permitiendo la unión del dominio tudor de 53BP1. 53BP1 se mantiene reclutada en los focos de reparación gracias a su interacción directa con la histona $\mathrm{\gamma H} 2 \mathrm{AX}$ (Ward et al, 2003), la interacción a través de los dominios BRCT de MDC1 y los residuos 1288 a 1409 de 53BP1 (Eliezer et al, 2009) y gracias a la función de la ubiquitina ligasa RNF8 sobre $\mathrm{YH} 2 \mathrm{AX}$ y MDC1. La interacción de 53BP1 con $\mathrm{YH} 2 \mathrm{AX}$ es crucial para el mantenimiento de $53 \mathrm{BP} 1$ en los focos de reparación, puesto que se ha observado que en células deficientes de $\mathrm{H} 2 \mathrm{AX}, 53 \mathrm{BP} 1$ es reclutado a los sitios de lesión pero no se mantiene retenido ahí (Mochan et al, 2004). La función de 53BP1, como se mencionaba anteriormente, es ayudar a la activación de proteínas transductoras como Chk2, permitiendo la activación de los puntos de control o checkpoints de las fases G2 y $\mathrm{S}$ del ciclo celular (Watrin \& Peters, 2009). Esta función la lleva a cabo sirviendo como andamio para facilitar la fosforilación de Chk2 por ATM. 53BP1 también es sustrato de ATM y la fosforilación en la serina 1219 después de IR media correctamente la respuesta al daño y la parada en la fase G2/M (Lee et al, 2009), mientras que la fosforilación en la 
serina 25, también por ATM, colabora en la interacción entre 53BP1 y PTIP para la total fosforilación y activación de Chk2 (Munoz et al, 2007).

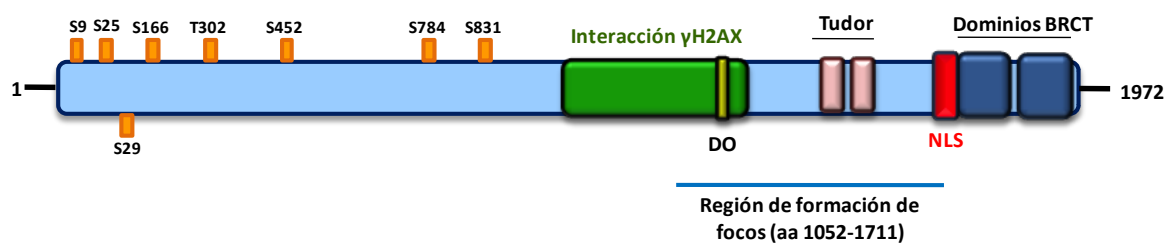

Figura 9. Representación esquemática de la proteína mediadora 53BP1. Se indica la posición de tres dominios conservados: los dominios tudor y BRCT, los cuales se abarcan los aminoácidos 1477-1632, 1714-1850 y 1865-1972 respectivamente. El dominio tudor, tras producirse daño interacciona con las lisinas metiladas 79 de la H3 y 20 de la H4. También se muestra la señal de localización nuclear (NLS), la región de interacción con $\gamma \mathrm{H} 2 \mathrm{AX}$, la región implicada en la formación de focos en respuesta al daño en el ADN y dentro de esta el dominio de oligomerización. Se muestran los residuos serina y treonina fosforilados en respuesta a DSBs. Adaptado de (Mochan et al, 2004).

La proteína mediadora BRCA1 participa tanto en la reparación de roturas de cadena sencilla como de cadena doble. También está involucrada en los mecanismos de reparación por HR y NHEJ (Wu et al, 2010). Mutaciones en esta proteína predisponen al desarrollo de cáncer de mama y ovario (Deng, 2006; Deng \& Wang, 2003). BRCA tiene dos dominios funcionales: el dominio RING en la región Nterminal y el dominio en tándem de BRCT en la región C-terminal. Igual a otros dominios RING de otras proteínas, el dominio RING de BRCA tiene actividad ubiquitina ligasa E3 y facilita la ubiquitinación de proteínas (Panier \& Durocher, 2009). La proteína CtIP (del inglés: CtBP interacting protein), previamente fosforilada en el residuo serina 327 por ATM, interacciona con los aa 1651-1863 (dominios $B R C T$ ) de BRCA1. Esta interacción es necesaria para la unión de BRCA1 (aa 341-748) a NBS1. El complejo BRCA1-CtIP-MRN es muy importante durante la fase S y G2 del ciclo celular para la eliminación de las DSBs y la reparación por HR (Chen et al, 2008). Una vez fosforilada la histona $\mathrm{H} 2 \mathrm{AX}$, la proteína BRCA puede ser activada de dos formas: directamente a través de la fosforilación de ATM o ATR sobre sus motivos $\mathrm{S} / \mathrm{TQ}$; o de forma indirecta a través de Chk2 y Chk1. ATM fosforila a Chk2 y esta a su vez fosforila los dominios S/TQ de BRCA1 (Caestecker \& Van de Walle, 2013). De manera contraria a Chk2, Chk1 no fosforila a BRCA1; sin embargo, la fosforilación de ATM o ATR sobre Chk1 hace que esta quinasa interaccione con los dominios BRCT de BRCA1. Esta interacción entre Chk1 y BRCA1 es importante para la activación del checkpoint G2-M en respuesta al daño en el ADN (Yarden et al, 2002). A continuación, en la figura 10 se detallará el reclutamiento de las proteínas anteriormente descritas para la correcta formación del foco de reparación. 


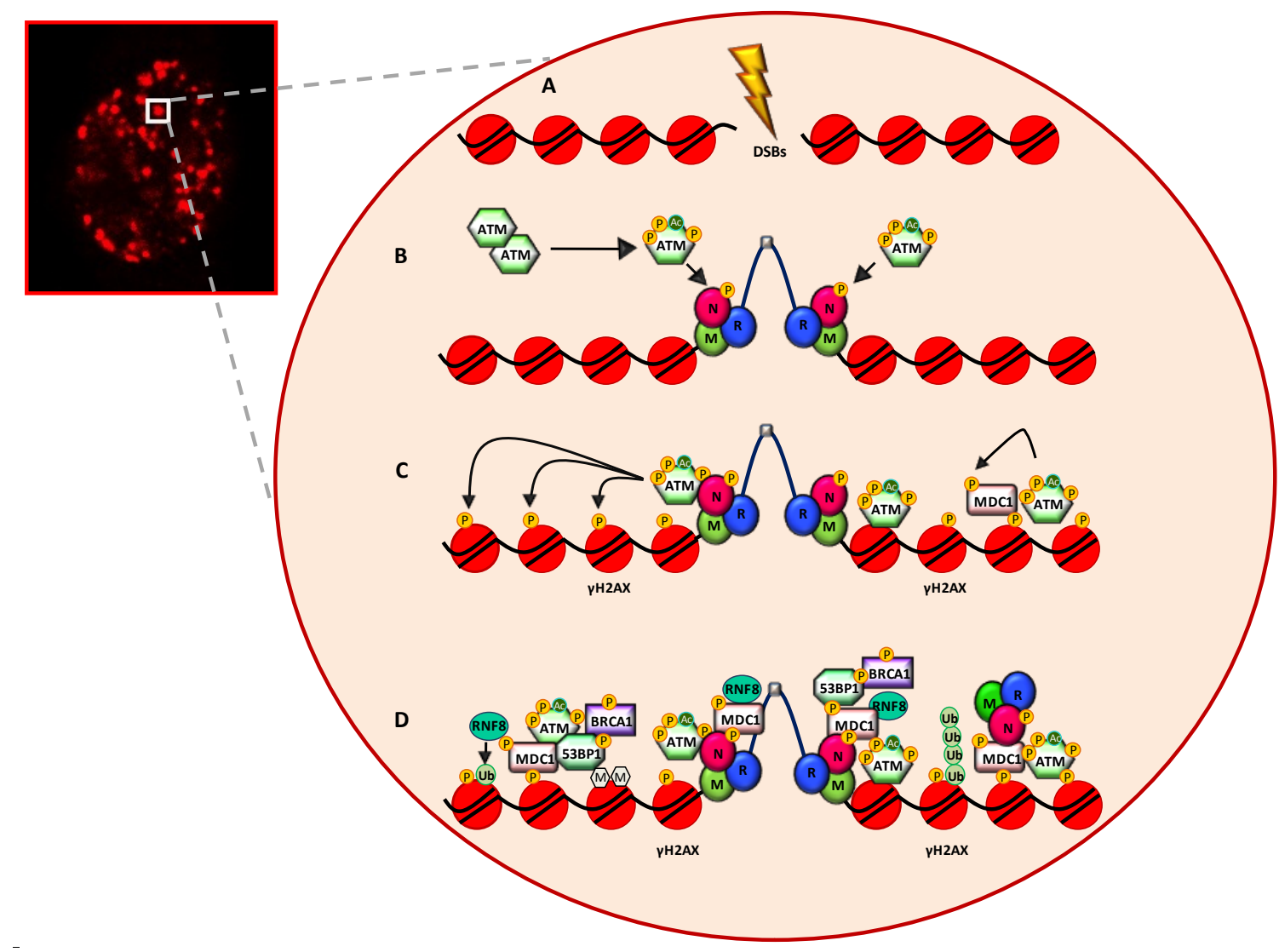

Figura 10. Pasos para la formación del foco de reparación nuclear en respuesta a roturas de doble cadena del ADN. Las roturas de doble cadena del ADN (DSBs) producidas por agentes exógenos 0 procesos celulares endógenos (A), son detectadas rápidamente por el complejo MRN, el cual ayuda al reclutamiento y activación de la quinasa ATM (B). La histona H2AX es fosforilada por ATM en el residuo serina $139 \quad(\gamma \mathrm{H} 2 \mathrm{AX})$, esta fosforilación sirve de marcador epigénetico para ubicar donde se ha producido el daño. La histona $\mathrm{YH} 2 \mathrm{AX}$ es reconocida por la proteína mediadora MDC1 también fosforilada por ATM (C). MDC1 conlleva a una mayor acumulación del complejo MRN, ayudando a la amplificación de la actividad local de ATM, expandiendo la cantidad de $\mathrm{yH} 2 \mathrm{AX}$ a lo largo de la cromatina (retroalimentación positiva). MDC1 interacciona con la ubiquitina-ligasa RNF8, que participa en el reclutamiento de las proteínas 53BP1 y BRCA1, ambas también fosforiladas por ATM. La acumulación de estas proteínas y sus múltiples copias forman los focos de reparación nucleares (D). 


\subsubsection{Función de las proteínas transductoras (PIKKs, Chk1 y Chk2) y efectoras ( $p 53$ y Cdc25) en la respuesta al daño en el ADN}

Dependiendo del tipo de daño, las quinasas Chk1 (del inglés: Checkpoint kinase 1) y Chk2 (del inglés: Checkpoint kinase 2) pueden ser activadas por ATR y ATM, respectivamente. Las quinasas Chk actúan como transductoras, amplificando la señal, y fosforilando gran variedad de sustratos que participan en la respuesta al daño en el ADN (Antoni et al, 2007). Aunque pueden tener funciones redundantes, su principal diferencia se encuentra en que Chk2 juega un papel importante en la transducción de la señal en respuesta a las DSBs, mientras que Chk1 es principalmente activada por ATR en respuesta a roturas de cadena sencilla y bloqueos en la horquilla de replicación (Smith et al, 2010).

Chk2 existe como monómero inactivo, y una vez se produce el daño, se localiza transitoriamente en los sitios lesionados del ADN. Chk2 es fosforilada en el residuo treonina 68 y activada por ATM con ayuda de las proteínas mediadoras MDC1 y 53BP1, haciendo que pase de monómero inactivo a dímero. Para activarse completamente debe tener lugar la trans-fosforilación de las treoninas 383 y 387 situadas en el loop de activación de la quinasa (Matsuoka et al, 2000; Stolz et al, 2011). A continuación Chk2 se moviliza por el nucleoplasma y difunde la señalización mediante la fosforilación de sus sustratos en el espacio nuclear (Lukas et al, 2003). Entre los sustratos de Chk2 se encuentran los factores de transcripción p53 y E2F1, las fosfatasas Cdc25A y Cdc25C, o la proteína BRCA1 (Cai et al, 2009).

p53 es un factor de transcripción que activa la expresión de varios genes relacionados con la inhibición del crecimiento y genes pro-apotóticos, lo cual puede resultar en apoptosis, parada irreversible del ciclo celular o senescencia (Efeyan \& Serrano, 2007). p53 puede ser fosforilado en la serina 15 por ATM y en la serina 20 por Chk1 y Chk2. Estas fosforilaciones bloquean la interacción entre la ubiquitina ligasa Mdm2 y este factor de transcripción, promoviendo la acumulación y estabilización de p53 (Antoni et al, 2007; Hirao et al, 2000). Chk2 también fosforila a MDM4 (regulador negativo de p53) en la serina 367 promoviendo su unión a la proteína 14-3-3 y su posterior degradación por Mdm2, incrementando así la estabilidad y actividad de p53 en respuesta al daño en el ADN (LeBron et al, 2006).

Cuando el daño en el ADN no puede ser reparado, Chk2 puede promover la apoptosis al fosforilar el factor de transcripción E2F1 en el residuo serina 364, resultando en su estabilización, activación transcripcional e inducción de apoptosis por un mecanismo independiente de p53 (Stevens et al, 2003). E2F1, además, puede regular positivamente a Chk2, lo cual conlleva a mayor activación de ATM, incrementando la actividad apoptótica de p53 (Powers et al, 2004). 
Chk1 y Chk2 fosforilan varios residuos de la fosfatasa Cdc25A incluyendo la serinas 123, 178 y 292, lo cual conlleva a la ubiquitinación y posterior degradación de esta fosfatasa. De este modo, el complejo cdk2/ciclinaE no puede ser defosforilado ni activado y, por lo tanto, no hay transición G1/S (Falck et al, 2001). También se ha demostrado que Chk2 puede fosforilar la fosfatasa Cdc25C (necesaria para la activación de los complejos CDK/Ciclina que regulan la progresión del ciclo celular) en el residuo serina 216, promoviendo su unión a la proteína 14-3-3, que la retiene en el citoplasma; produciendo un retraso en la transición $\mathrm{G} 2 / \mathrm{M}$ y evitando que las células entren en mitosis (Antoni et al, 2007).

Por último, como se mencionaba anteriormente, Chk2 fosforila a la proteína BRCA1 específicamente en el residuo serina 988, resultando en la disociación de esta proteína de los focos de reparación. Una vez liberado y activado BRCA1, forma un complejo con BRCA2, la cual puede interaccionar directamente con la proteína recombinasa Rad51, importante en la reparación por recombinación homóloga (Xia et al, 2001).

\subsubsection{Vías de reparación de las DSBs: reparación por unión de los extremos no homólogos y recombinación homóloga}

La reparación de las roturas de doble cadena es llevada a cabo por dos vías principales, la unión de extremos no homólogos NHEJ (del inglés: nonhomologous end-joining) (Lieber, 2010) y la recombinación homóloga HR (del inglés: homologous recombination) (Heyer et al, 2010). Las DSBs con los extremos libres producidas por nucleasas e IR pueden ser reparadas por cualquiera de las dos vías, mientras que las producidas por bloqueos en la horquilla de replicación son reparadas principalmente por HR (Helleday et al, 2007). La reparación NHEJ ocurre en cualquier fase del ciclo celular, mientras que la reparación HR es específica para células en fase $S$ y fase $G 2$ debido a que es necesaria la presencia de las dos cromátidas, de tal forma que se pueda utilizar como molde una de ellas para restaurar de manera fiel la continuidad del genoma (Cromie et al, 2001).

En la NHEJ, las proteínas Ku70/Ku80 y DNA-PK son reclutadas a ambos extremos del ADN lesionado, y una vez allí DNA-PK es activada por acción del heterodímero Ku70/Ku80. La actividad de DNA-PK estabiliza los extremos finales del ADN y previene la resección de estos a través de diferentes fosforilaciones, facilitando el reclutamiento de otros factores de reparación como Artemis, que es la responsable de llevar a cabo el procesamiento de los extremos libres para que se puedan religar (Goodarzi et al, 2006). Posteriormente, el complejo XRCC4/ADN-ligasa4 es reclutado promoviendo la religación de los extremos rotos ya procesados con la ayuda del factor XLF (Mahaney et al, 2009; van Gent \& van der Burg, 2007). En este proceso también puede participar el complejo MRN al facilitar la reparación enlazando los 
dos extremos finales del ADN (de Jager et al, 2001). A través de esta vía se unen correctamente los extremos libres del $A D N$, pero frecuentemente se pierde información genética debido al procesamiento de los extremos de las DSBs por nucleasas (lijima et al, 2008).

En la HR, el complejo MRN detecta las DSBs y por acción de la actividad nucleasa de Mre11 y la participación de otras proteínas como CtIP, EXO1 y ADN2 nucleasas, se realiza un corte (eliminación de nucleótidos) en dirección $5^{\prime}-3^{\prime}$. De esta forma se extrae un segmento de los extremos $5^{\prime}$ de la zona donde se encuentra la DSB, con el fin de dejar los extremos 3' libres. A estos extremos 3' se une la proteína RPA para proteger el ADN de futuros cortes y evitar la formación de la estructura secundaria de la cadena sencilla. RPA es sustituido por la proteína recombinasa Rad51, la cual forma el filamento nucleoproteico (ADN recubierto por cientos de monoméros de esta proteína) sobre el extremo libre de ADN monocatenario mediando la invasión de esta cadena libre a la doble cadena de la cromátida hermana. Para llevar a cabo este paso es necesaria la participación de proteínas como Rad52, BRCA2 y proteínas de anemia de Fanconi, entre otras. Rad52 interacciona con RPA y Rad51, favoreciendo la formación del filamento. La proteína supresora de tumores BRCA2 regula la acumulación de Rad51 a los sitios de lesión (Yuan et al, 1999). BRCA2 se comporta como proteína andamio para Rad51 inactiva y una vez se produce el daño, Rad51 es fosforilado y liberado de BRCA2 para la formación del filamento (Pellegrini et al, 2002). Después de la invasión del filamento nucleoproteico y tras desplazar una de las cadenas, se forma un heterodúplex de ADN en aquella región complementaria dando lugar al lazo D (del inglés: Displacement-loop). Rad51 también interviene en la síntesis de la nueva cadena de ADN en el heterodúplex a partir del extremo 3' del sitio original de la rotura, usando la cadena homóloga de la cromátida hermana como molde. Entre la transición del homodúplex y el heterodúplex se forma una estructura en forma de X Ilamada unión Holliday (del inglés: Holliday Junction), esta estructura es el resultado de la invasión y posterior entrecruzamiento de las cromátides hermanas (Li \& Heyer, 2008; West, 2003). A medida que se va sintetizando la nueva cadena de ADN, la unión Holliday también se va desplazando en el mismo sentido con ayuda de Rad54, WRN y BLM. El desplazamiento de la unión Holliday facilita la liberación de la cadena recién sintetizada al alinearse y reconectarse los dos extremos rotos. Por último se lleva a cabo la ligación por ADN ligasas (Helleday et al, 2007).

\subsubsection{Papel de la ubiquitinación en la respuesta al daño en el ADN}

La ubiquitinación es una modificación post-traduccional en la cual la glicina de la región C-terminal de la ubiquitina (proteína de 76 aa, ubicua y altamente conservada) forma un enlace amida con el nitrógeno de la lisina de la proteína sustrato. Para llevarse a cabo el proceso de ubiquitinación se requiere la 
participación de tres factores diferentes: la enzima activadora de la ubiquitina (E1), la enzima de conjugación de la ubiquitina (E2) y la ubiquitina ligasa (E3).

En la respuesta al daño en el ADN, la fosforilación y el reclutamiento de MDC1 a los sitios de lesión, inician una cascada de ubiquitinación, cuyo objetivo principal es la monoubiquitinación, la poliubiquitinación (mediada por la unión de varias ubiquitinas a través de sus residuos de lisina) o multiubiquitinación de proteínas (Messick \& Greenberg, 2009). Existen 7 residuos de lisina: K6, K11, K27, K29, K33, K48 y $\mathrm{K} 63$ y dependiendo del residuo de poliubiquitinación se define el destino de la proteína sustrato. Por ejemplo, la poliubiquitinación de las lisinas K48, K29 y K11 marcan las proteínas para ser degradas por el proteasoma, mientras que la poliubiquitinación de la lisina 63 usualmente es señal para el reclutamiento de proteínas (Pickart \& Eddins, 2004).

RNF8 (del inglés: RING finger 8) es una ubiquitina ligasa E3 que regula la ubiquitinación de proteínas situadas en los sitios del ADN lesionado. Para llevar a cabo su actividad dispone de un dominio de dedo RING en su región C-terminal (Mailand et al, 2007). Además, RNF8 tiene un dominio FHA en su región N-terminal importante para la formación de los focos debido a su interacción con proteínas fosforiladas. Este dominio reconoce específicamente motivos TQXF como los que se encuentran en la proteína MDC1, ayudando al reclutamiento de las proteínas 53BP1 y BRCA1 a los focos de reparación (Panier \& Durocher, 2009). La localización de RNF8 en los focos depende de $\mathrm{YH} 2 \mathrm{AX}$ y MDC1 pero no de NBS1, 53BP1 o BRCA1 (Kolas et al, 2007).

Después de la interacción de RNF8 y MDC1 se activa la ubiquitinación de pH2AX. Para llevar a cabo este proceso, la ubiquitina ligasa E3 RNF168 se une a través de sus motivos de interacción MIU (del inglés: motifs interacting with ubiquitin) con la ubiquitina, estimulando la ubiquitinación de las lisinas 63. Una tercera ubiquitina ligasa, HERC2, interacciona con el dominio FHA de RNF8 facilitando la formación del complejo RNF8-UBC13. Ambas proteínas catalizan la poliubiquitinación a través de los residuos de lisina 63 sobre $\mathrm{YH} 2 \mathrm{AX}$, lo cual sugiere que UBC13 actúa como E2 para RNF8 (Bekker-Jensen \& Mailand, 2011). Las cadenas de ubiquitinas unidas por sus lisinas 63, ensambladas por RNF8 con ayuda de RNF168, son recononocidas por RAP80, la cual recluta a BRCA1 a los sitios de lesión (Figura 11) (Panier \& Durocher, 2009). 


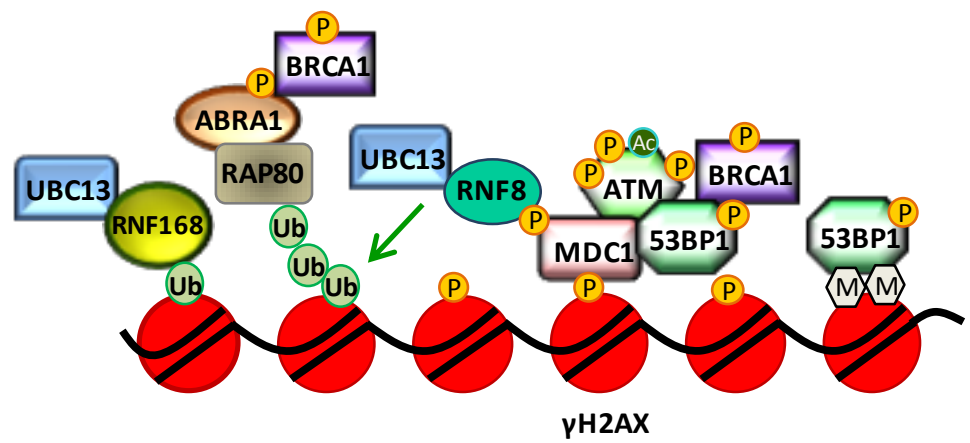

Figura 11. Modelo de ubiquitinación dependiente de RNF8 y RNF168. Los residuos fosforilados de MDC1 son reconocidos por el dominio FHA de RNF8. RNF8 forma un complejo con UBC13 que conlleva a la ubiquitinación de la histona H2AX. Posteriormente, RNF168 es reclutado, formando también un complejo con UBC13 incrementando la ubiquitinación de la histona H2AX dependiente de RNF8. RAP80 interacciona con los sustratos ubiquitinados ( $\mathrm{H} 2 \mathrm{AX}$ ) reclutando a BRCA a través de ABRA1. Aún no se conoce el mecanismo por el cual la ubiquitinación ayuda al reconocimiento de las lisinas metiladas de las histonas $\mathrm{H} 3$ y $\mathrm{H} 4$ por 53BP1. Ub: ubiquitina, p: residuo fosforilado, M: residuo metilado.

\subsubsection{Desensamblaje de focos de reparación}

Los focos de reparación son estructuras formadas por la relajación local de la cromatina, las modificaciones post-traduccionales de las histonas y el reclutamiento y acumulación de proteínas para reparar el daño (Kruhlak et al, 2006). Los focos pueden ser visualizados citológicamente y el número de células con focos o el número de focos en cada célula incrementa proporcionalmente según la intensidad del daño recibido, por ejemplo los Grays (Gy) de radiación ionizante (Polo \& Jackson, 2011).

Una vez que la lesión ha sido reparada, los focos de reparación son desensamblados y el ciclo celular es reanudado. En el proceso de "apagado" de la respuesta al daño en el ADN principalmente se revierten los cambios post-traduccionales como las ubiquitinaciones y las fosforilaciones. En este caso participan diferentes fosfatasas como PP1, PP2A, PP4, PP6 y WIP1 encargadas de defosforilar diferentes proteínas, de las cuales una de las más importantes por su comportamiento de marcador epigenético del daño es la yH2AX (Chowdhury et al, 2005; Moon et al, 2010; Nakada et al, 2008). De manera similar, se ha demostrado la participación de enzimas deubiquitinantes que contrarrestan la acción de RNF8 y RNF168 sobre $\mathrm{HH} 2 \mathrm{AX}$. Entre ellas encontramos la proteína USP3 (del inglés: Ubiquitin-specific protease 3), encargada de deubiquitinar la histona H2AX (Nicassio et al, 2007); BRCC36, la cual es reclutada a los sitios de lesión como parte del complejo BRCA1/BRCA2 y se comporta como reguladora negativa de RNF8 y RNF168 al remover las cadenas de ubiquitinas 
de la proteína sustrato; y, por último, la proteína OTUB1, que se une e inhibe la E2 UBC13 (Bartocci \& Denchi, 2013)

Otro de los mecanismos para el desensamblaje de los focos es la degradación de las proteínas que participan en la respuesta al daño en el ADN. Las DSBs inducen la poliubiquitinación de proteínas como 53BP1, MDC1, NBS1 y ATRIP a través de la formación de cadenas de ubiquitina unidas a la K48 con el fin de ser degradadas en el proteasoma (Ramadan \& Meerang, 2011).

Gracias a todos estos procesos de señalización mediados por cambios posttraduccionales e interacciones, comenzando desde la detección del daño al ADN hasta la acción de las proteínas efectoras, tienen como principal objetivo el retraso de la progresión del ciclo celular con el fin de que se repare el ADN lesionado. Si la reparación falla, puede reanudarse el ciclo celular aunque con alteraciones que producen inestabilidad genómica y senescencia. Sin embargo, si el daño es severo, la célula entra en apoptosis.

\subsection{Daño en el ADN y Cáncer}

La inestabilidad genómica incluye la acumulación de mutaciones en el ADN y alteraciones en el número y estructura de los cromosomas. El mantenimiento de la integridad genómica gracias a una correcta respuesta al daño en el ADN es crítica para prevenir la tumorogénesis (Gorgoulis et al, 2005). Una de las manifestaciones más drásticas de la importancia que tienen los mecanismos de reparación, aparte de estar asociados a una gran variedad de enfermedades (xeroderma pigmentosum, síndrome de Cockayne, tricotiodistrofia, síndrome Nijmegen, síndrome neurodegenerativo ataxia talangiectasia, entre otros), es la predisposición al desarrollo de diferentes tipos de cáncer (Tabla 2, pág. 29). Por ejemplo, la deficiencia de factores de reparación NER en el xeroderma pigmenstosum incrementa significativamente el riesgo de desarrollo de cáncer de piel y melanoma puesto que se presenta una reparación defectuosa de las lesiones UV producidas en los queratinocitos. Una de las mutaciones más prevalentes que conllevan a la aparición del cáncer de mama y ovario se encuentran en los genes BRCA1 y BRCA2 (Fackenthal \& Olopade, 2007)(Fackenthal and Olopade, 2007)(Network, 2011). Mutaciones asociadas a la pérdida funcional de CHK2, ATM, NBS1 y RAD50 aumentan el riesgo de desarrollar cáncer de mama, cáncer pancreático y cáncer de ovario, lo que nos indica la importancia de la vía de ATM en la reparación del daño en el ADN (Walsh \& King). También se ha observado que el $15 \%$ del cáncer colorrectal espóradico muestra un acortamiento o alargamiento de secuencias repetitivas de dinucleótidos (inestabilidad microsatélite), causado por un defecto en la capacidad de reparar errores por el mecanismo de mistmach (Lord \& Ashworth, 2012). 
Las terapias antitumorales como radiación y quimioterapia citotóxica tienen como objetivo la muerte celular por el daño producido en el ADN, evitando la proliferación y diferenciación de células cancerosas. Este tipo de tratamientos son ampliamente usados en la medicina actual como principal medida contra el cáncer. Sin embargo, la utilidad de estos tratamientos se ve frecuentemente limitada puesto que no diferencian células normales de cancerosas. Además, las células cancerosas escapan de la muerte al sobre-activar las vías de reparación del ADN, eliminando el daño inducido por los tratamientos. Por lo tanto, hoy en día, se buscan diferentes alternativas que aumenten la eficacia selectiva del tratamiento sobre las células cancerosas sin afectar a las células normales. Además, se ha propuesto como tratamiento adyuvante el uso de inhibidores de proteínas implicadas en la reparación del $A D N$, con el fin de mejorar el efecto de la terapia antitumoral al potenciar la muerte de células tumorales y reducir la resistencia a estos tratamientos (Barakat et al, 2012). Varios inhibidores como wortmanina, LY2940002 y cafeína inhiben la función de ATM, pero son poco específicos. Sin embargo, el inhibidor KU55933 parece ser un inhibidor específico de ATM puesto que bloquea la fosforilación de diferentes sustratos, entre ellos, NBS1, H2AX, Chk2 y p53. Por lo tanto, el uso de este inhibidor en combinación con tratamientos con drogas como camptotecina, doxorubicina y etopósido o bien radiación ionizante, es una buena alternativa para sensibilizar e inducir la muerte en células cancerosas (Hickson et al, 2004; Kelley \& Fishel, 2008). También, es un interesante blanco en la terapia contra el cáncer el complejo MRN puesto que es un componente clave en la reparación de las roturas de doble cadena del ADN. 


\begin{tabular}{|c|c|c|c|c|c|}
\hline $\begin{array}{c}\text { Gen } \\
\text { mutado }\end{array}$ & Defecto en DDR & En ferme dad & $\begin{array}{l}\text { Desorden } \\
\text { Neu rológico }\end{array}$ & Cáncer & Otros \\
\hline XPA-XPG & NER & $\begin{array}{l}\text { Xeroderma } \\
\text { Pigmentoso }\end{array}$ & $\begin{array}{c}\text { Microcefalia, } \\
\text { neu ro degeneración }\end{array}$ & $\begin{array}{l}\text { Cáncer de } \\
\text { piel y } \\
\text { melanoma }\end{array}$ & $\begin{array}{l}\text { fotosensibilidad, } \\
\text { ictiosis }\end{array}$ \\
\hline $\begin{array}{l}\text { CSA, CSB, } \\
\text { XPB, XPD, } \\
\text { XPG }\end{array}$ & NER & $\begin{array}{l}\text { Síndrome de } \\
\text { Cockayne }\end{array}$ & $\begin{array}{c}\text { Microcefalia, } \\
\text { neu ro degeneración }\end{array}$ & & $\begin{array}{l}\text { Fo to sensibilidad, } \\
\text { d efectos en el } \\
\text { crecimien to }\end{array}$ \\
\hline XPB, XPD & NER & Tric otio distro fia & Neurodegeneración & & $\begin{array}{c}\text { Ano malías en el } \\
\text { pelo, } \\
\text { fotosensibilidad, } \\
\text { ictiosis }\end{array}$ \\
\hline $\begin{array}{c}\text { ATM, } \\
\text { BRCA1, } \\
\text { BRCA2, } \\
\text { CHK2, } \\
\text { NBS1, } \\
\text { RAD50, } \\
\text { RAD 51C }\end{array}$ & $\begin{array}{l}\text { Recombinación } \\
\text { Homóloga, } \\
\text { Señalización del } \\
\text { daño }\end{array}$ & & & $\begin{array}{l}\text { Cáncer de } \\
\text { mama, } \\
\text { cáncer de } \\
\text { ovario }\end{array}$ & \\
\hline ARTEMIS & NHEJ & $\begin{array}{c}\text { Radiosensibilidad } \\
\text { severa combin ad a } \\
\text { con } \\
\text { inmun odeficiencia }\end{array}$ & & Linfomas & $\begin{array}{l}\text { Defectos en el } \\
\text { crecimien to }\end{array}$ \\
\hline ATM & $\begin{array}{l}\text { Señalización del } \\
\text { daño, } \\
\text { reparación DSBs }\end{array}$ & $\begin{array}{c}\text { sín drome } \\
\text { neurodegenera- } \\
\text { tivo ataxia } \\
\text { talangiectasia }\end{array}$ & $\begin{array}{c}\text { Ataxia, } \\
\text { degeneración } \\
\text { cerebelar }\end{array}$ & $\begin{array}{l}\text { Linfomas, } \\
\text { leucemias, } \\
\text { cáncer de } \\
\text { mama }\end{array}$ & $\begin{array}{l}\text { Defectos en el } \\
\text { crecimien to, } \\
\text { infertilidad, } \\
\text { defectos } \\
\text { metabólicos }\end{array}$ \\
\hline Mre11 & $\begin{array}{l}\text { Señalización del } \\
\text { daño, } \\
\text { reparación DSBs }\end{array}$ & $\begin{array}{c}\text { desorden similar a } \\
\text { la ataxia- } \\
\text { telangiectasia }\end{array}$ & $\begin{array}{c}\text { Ataxia, } \\
\text { degeneración } \\
\text { cerebelar }\end{array}$ & & \\
\hline Rad50 & $\begin{array}{l}\text { Señalización del } \\
\text { daño, } \\
\text { reparación DSBs }\end{array}$ & $\begin{array}{l}\text { desorden similar } \\
\text { al sínd ro me de } \\
\text { rotura Nijmegen }\end{array}$ & Microcefalia & & $\begin{array}{l}\text { Defectos en el } \\
\text { crecimien to, } \\
\text { anormalidades } \\
\text { faciales }\end{array}$ \\
\hline NBS1 & $\begin{array}{l}\text { Señalización del } \\
\text { daño, } \\
\text { reparación DSBs }\end{array}$ & $\begin{array}{l}\text { síndrome de } \\
\text { rotura Nijmegen }\end{array}$ & Microcefalia & $\begin{array}{l}\text { Linfomas } \\
\text { de células B }\end{array}$ & $\begin{array}{l}\text { Defectos en el } \\
\text { crecimien to, } \\
\text { anormalidades } \\
\text { faciales }\end{array}$ \\
\hline RNF168 & $\begin{array}{l}\text { Señalización del } \\
\text { daño, } \\
\text { reparación DSBs }\end{array}$ & $\begin{array}{l}\text { sín drome de } \\
\text { Riddle }\end{array}$ & & & $\begin{array}{l}\text { Inmuno deficien- } \\
\text { cia, Defectos en el } \\
\text { crecimien to }\end{array}$ \\
\hline
\end{tabular}

Tabla 2. Alteración de proteínas de la respuesta al daño en el ADN y su relación con enfermedades humanas 


\section{APOPTOSIS}

La apoptosis es una forma de muerte celular segura y controlada, llevada a cabo por un conjunto de reacciones químicas y cambios morfológicos. El término apoptosis fue usado por primera vez por los científicos Kerr, Willie y Currie en el año 1972 para describir una forma de muerte celular diferente a la necrosis, al observar que se producían una serie de cambios secuenciales que no terminaban en la pérdida de la integridad de la membrana, y no producían respuesta inflamatoria (Kerr et al, 1972). La apoptosis es un proceso fisiológico regulado genéticamente, de vital importancia en el desarrollo de los organismos (morfogénesis, diferenciación sexual, formación y maduración de los sistemas nervioso e inmune) y en la homeostasis celular. En el mecanismo de la apoptosis participan una gran variedad de proteínas que promueven la muerte celular a través de la amplificación de la cascada de señalización y la retroalimentación positiva, para asegurar que una vez que se ha iniciado el proceso, este sea llevado a cabo. Cuando la célula entra en apoptosis y es desintegrada desde su interior, los restos celulares son eliminados por acción de los fagocitos, impidiendo así la exposición del material intracelular (Ulukaya et al, 2011).

En el interior de la célula suceden una gran variedad de cambios que son característicos del proceso de apoptosis, entre los cuales se encuentran: la condensación de la cromatina en la periferia nuclear, la fragmentación del núcleo por nucleasas endógenas produciendo pequeños fragmentos de ADN (tamaño promedio de $200 \mathrm{pb}$ ), la disminución de tamaño (pérdida de hasta el 30\% del volumen celular), la dilatación del retículo endoplasmático (originando la formación de vesículas que se unen a la membrana plasmática adquiriendo la forma de burbujas también llamadas "blebs"), la fragmentación nuclear y citoplasmática (que resulta en la formación de los denominados cuerpos apoptóticos) y la exposición de marcadores como la fosfatidilserina que en condiciones normales se encuentra en la cara interna de la membrana plasmática y que en la apoptosis pasa al exterior para ser reconocida por los fagocitos. De forma contraria, en la necrosis se pierde rápidamente la integridad de la membrana, liberando todo el contenido celular al espacio extracelular, desencadenando la respuesta inmune, específicamente la respuesta inflamatoria (Hacker, 2000; Hengartner, 2000).

En las células se distinguen dos rutas principales que usualmente operan juntas. Ambas rutas están relacionadas con la activación proteolítica de cisteín-proteasas llamadas caspasas (cisteinil-aspartato proteasas), las cuales se van activando en cascada con el objetivo final de activar proteínas que promoverán la muerte celular. La ruta extrínseca o ruta de los receptores de muerte, es inducida por señales de estrés extracelular que son detectadas por receptores transmembrana específicos. Por otro lado, la ruta intrínseca o ruta mitocondrial, está regulada por los miembros 
de la familia Bcl-2 (del inglés: B-cell leukemia/lymphoma 2), que participan en la regulación y liberación de proteínas como el citocromo c y Smac/Diablo del espacio mitocondrial al citosol, induciendo la activación de la ruta de las caspasas. Como se mencionaba anteriormente, las dos rutas están relacionadas, y las proteínas de una ruta pueden influenciar en la otra (Igney \& Krammer, 2002). La ruta extrínseca e intrínseca convergen en la ruta o fase de ejecución, considerada la etapa final de la apoptosis. Esta ruta comienza con el procesamiento de la caspasa 3, que tiene efecto en la fragmentación del ADN, degradación del citoesqueleto, formación de los cuerpos apoptóticos y expresión de ligandos para los fagocitos (Taylor et al, 2008).

\subsection{Caspasas}

Las caspasas son una familia de proteínas que contienen un residuo de cisteína en el centro activo, que participa en la ruptura proteolítica de motivos que contienen residuos de ácido aspártico. Existen 14 tipos de caspasas que se pueden dividir en tres grupos dependiendo de la homología de su secuencia y la especificidad de sus sustratos: las caspasas del grupo I (caspasas 1, 4, 5, 13 y 14) son procesadoras de citoquinas y están relacionadas con inflamación; las caspasas que participan en el proceso de apoptosis, se dividen en caspasas iniciadoras o activadoras del grupo II ( caspasas $8,9,10$ y 2 ) y caspasas efectoras o ejecutoras del grupo III ( caspasas 3,6 y 7) (Rupinder et al, 2007).

Las caspasas se expresan en la célula como proenzimas (zimógenos), y para ser activadas sufren una fragmentación proteolítica (dos cortes) en residuos de ácido aspártico que generan subunidades de la enzima activa que inician el proceso de apoptosis. Las caspasas iniciadoras son capaces de auto-activarse catalíticamente, mientras las caspasas efectoras necesitan a las caspasas iniciadoras para que estas las activen por ruptura proteolítica (Siegel, 2006). El dominio proteasa de las caspasas se puede dividir en dos subunidades, una subunidad grande (17-21 kDa) donde se encuentra el sitio activo, y una subunidad pequeña (10-13 kDa). Las caspasas iniciadoras tienen dominios importantes para la interacción entre proteínas llamados dominio efector de muerte DED (del inglés: death-effector domain) y dominio de activación y reclutamiento de caspasas CARD (del inglés: caspase activation and recruitment domains). El dominio DED (presente en las pro-caspasas 8 y 10) y CARD (presente en las pro-caspasas 2 y 9) son dominios de muerte DD (del inglés: death domain) que interaccionan con proteínas adaptadoras que tienen dominios homólogos (Weber \& Vincenz, 2001). Las caspasas efectoras no tienen dominios DED ni CARD, y son encargadas de procesar múltiples sustratos celulares, como proteínas del citoesqueleto, proteínas de reparación del ADN y proteínas del ciclo celular (Ulukaya et al, 2011). 


\subsection{Ruta extrínseca o de los receptores de muerte}

La activación de esta ruta está mediada por receptores de muerte, que son miembros de la superfamilia de receptores del factor de necrosis tumoral TNF (del inglés: tumor necrosis factor), tales como el receptor TNFR1, los receptores FAS (CD95 (del inglés: cytotoxicity-dependent protein 95) o APO-1 (del inglés: apoptosis-1 protein)) y los receptores TRAIL (del inglés: TNF-related apoptosis-inducing ligand). Los miembros de esta familia comparten similitud en el dominio extracelular rico en cisteínas y en un dominio intracelular formado por aproximadamente 80 aa, llamado dominio de muerte, importante para la transducción de la señal apotótica (Ashkenazi \& Dixit, 1998). Los receptores de muerte son activados a través de la unión con sus ligandos, tales como TNF- $\alpha$, Fas-Ligando y TRAIL. Una vez los ligandos se han unido a sus correspondientes receptores, diferentes proteínas adaptadoras citoplasmáticas son reclutadas, de tal forma que los dominios DD tanto del receptor como de la proteína interaccionan, activándose y transmitiendo la señal de muerte hacia el interior de la célula (Schmitz et al, 2000). La unión del ligando TNF a su receptor conlleva a la interacción con la proteína adaptadora TRADD (del inglés: TNF receptor type 1 associated death domain protein). Posteriormente se produce el reclutamiento de FADD (del inglés: fas-associated protein with death domain), mismo evento que ocurre cuando el ligando de FAS se une a su receptor (Wajant, 2002). Posteriormente, la proteína adaptadora FADD unida al receptor de muerte recluta la pro-caspasa 8 formándose el complejo de señalización inductor de muerte DISC (del inglés: death-inducing signaling complex) (Scott et al, 2009). Este complejo da lugar a la activación de caspasas iniciadoras (caspasas 8 y 10) que a continuación activarán las caspasas efectoras (caspasas 3 y 7). De esta forma se inicia la fase de ejecución de la apoptosis (Figura 12A, pág. 34) (Fuentes-Prior \& Salvesen, 2004).

\subsection{Ruta intrínseca o ruta mitocondrial}

Esta vía es activada por estrés celular producido por agente $s$ quimioterapéuticos, radiación UV, daño en el ADN, ausencia de factores de crecimiento, entre otros, que inducen la activación del gen supresor de tumores p53 y de proteínas proapoptóticas de la familia Bcl-2. Estos estímulos conllevan a la pérdida del potencial transmembrana de la mitocondria resultando en la permeabilización de la membrana externa mitocondrial (considerada el punto de no retorno en la apoptosis), y por ende la liberación al citosol de proteínas como citocromo c, Smac/Diablo (del inglés: second mitochondria-derived activator of caspases), y la proteasa HtrA2/Omi (del inglés: high temperature requirement protein $\boldsymbol{A}$ serine protease 2). Una vez liberado el citocromo $c$, se une al factor activador de la apoptosis 1, APAF-1 (del inglés: apoptotic protease activating factor-1), los cuales se oligomerizan y reclutan a la pro-caspasa 9 para formar un complejo heptamérico 
llamado apoptosoma (Bratton \& Salvesen, 2010; Hill et al, 2004). En el apoptosoma se activa la caspasa 9 y esta a su vez promueve la activación de las caspasas efectoras 3, 6 y 7, comenzando así el desmantelamiento celular (Figura 12B, pág. siguiente) (Riedl \& Salvesen, 2007). Smac/Diablo y HtrA2/Omi promueven la apoptosis mediante la inhibición de la actividad de proteínas inhibidoras de la apoptosis IAPs (del inglés: inhibitors of apoptosis proteins) (Chai et al, 2000; Schimmer, 2004). Otras proteínas también son liberadas al citosol como el factor inductor de la apoptosis AIF (del inglés: apoptosis induction factor) y la endonucleasa G (Green \& Evan, 2002). Después de su liberación ambas proteínas se translocan al núcleo donde AIF produce la fragmentación nuclear y la condensación de la cromatina en la periferia nuclear (Joza et al, 2001) y la endonucleasa $\mathrm{G}$ se encarga de la fragmentación del ADN internucleosomal (Li et al, 2001).

Figura 12. Principales vías de señalización de la apoptosis. A. Ruta extrínseca. Esta ruta es activada tras la unión de los ligandos específicos a sus correspondientes receptores de muerte, lo cual conlleva al reclutamiento de las proteínas FADD y caspasa 8. Tras la dimerización y activación de la caspasa 8, esta puede procesar directamente y activar las caspasas 3 y 7 desencadenando la apoptosis o puede procesar la proteína sólo-BH3 Bid activándola (tBid) y de esta forma activar la ruta intrínseca de la apoptosis. B. Ruta intrínseca. Después de un estímulo apoptótico intrínseco como daño en el ADN o estrés del retículo endoplásmatico, las proteínas sólo-BH3 son activadas y estas a su vez ayudan a la activación Bax y Bak que median la permeabilización de la membrana externa mitocondrial induciendo la difusión al citosol de proteínas mitocondriales como el citocromo c, HtrA2/Omi y Smac/Diablo. El citocromo c se une con Apaf-1 y procaspasa-9, dando lugar a la formación del apoptosoma donde se activa la caspasa-9, la cual procesa y activa las caspasas ejecutoras 3 y 7, comenzando el desmantelamiento celular. Adaptado de (Igney \& Krammer, 2002) y (Tait \& Green, 2010). 


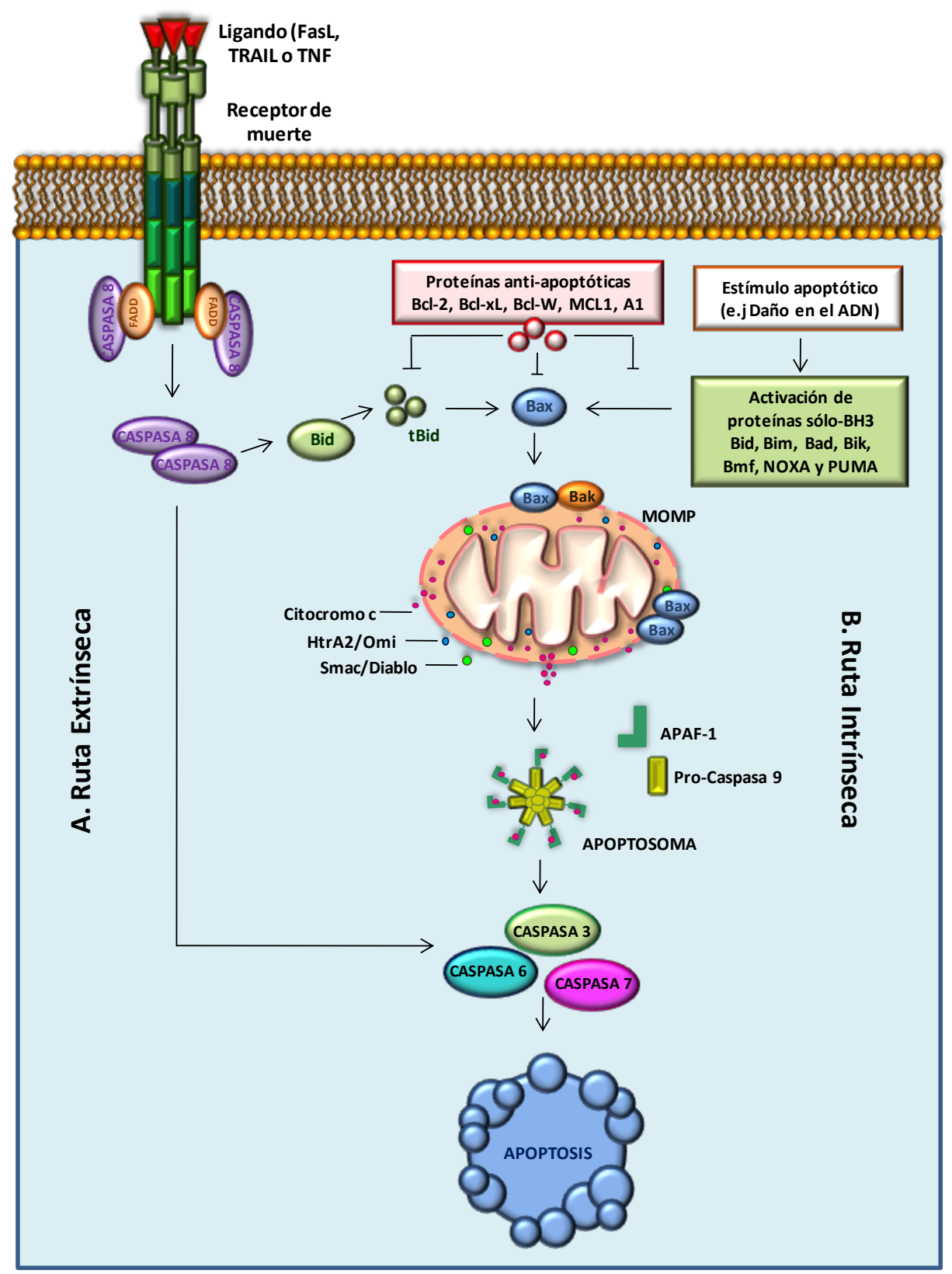




\subsubsection{Regulación de la apoptosis por proteínas de la familia $\mathrm{Bcl}-2$}

Esta familia debe su nombre al primer miembro que se descubrió: el proto-oncogén Bcl-2. Se observó que su expresión no promovía la proliferación celular como otros oncogenes, sino que bloqueaba la muerte celular ante múltiples estímulos fisiológicos y patológicos (McDonnell et al, 1989). La permeabilización de la membrana externa de la mitocondria o MOMP (del inglés: mitochondrial outer membrane permeabilization) se encuentra bajo el control de las proteínas de la familia Bcl-2 que ayudan a la difusión del citocromo c y otras proteínas mediadoras de la apoptosis hacia el citosol (Cory \& Adams, 2002). La alteración de proteínas de esta familia está asociada al desarrollo de cáncer, enfermedades autoinmunes y desórdenes neurodegenerativos. Esta familia se caracteriza por tener 4 dominios de homología BH (del inglés: Bcl-2 Homology) llamados $\mathrm{BH} 1, \mathrm{BH} 2, \mathrm{BH} 3$ y $\mathrm{BH} 4$ que corresponden a segmentos $\alpha$-hélices. Los miembros de esta familia han sido identificados y clasificados en tres grupos generales según los dominios BH conservados y sus funciones en la apoptosis (Figura 13). El primer grupo, formado por proteínas anti-apoptóticas como Bcl-2, Bcl-xL (del inglés: B-cell lymphoma-extra large), $\mathrm{Bcl}-\mathrm{W}, \mathrm{MCL}-1$ (del inglés: Induced myeloid leukemia cell differentiation protein) y A1/BFL-1 (del inglés: Bcl-2-related protein A1), inhiben la muerte celular a través de la interacción directa con proteínas pro-apoptóticas. El segundo grupo, formado por las proteínas pro-apoptóticas o ejecutoras como Bax (del inglés: BCl-2associated $\mathbf{X}$ protein), Bak (del inglés: BCl-2 homologous antagonist killer) y Bok (del inglés: $B \mathrm{Cl}-2$ related ovarian killer), se caracterizan por tener 4 dominios $\mathrm{BH}$ (llamadas también proteínas multidominios) y por participar directamente en la MOMP. Por último, el tercer grupo, está formado por las proteínas pro-apoptóticas sólo-BH3 de las que destacamos a las proteínas activadoras Bid (del inglés: $\mathbf{B H} 3$ interacting-domain death agonist) y Bim/Bcl2-L-11 (del inglés: Bcl-2-like protein 11), que pueden activar directamente a Bax y Bak, y a las proteínas sensibilizadoras Bmf (del inglés: Bcl-2-modifying factor), Bik (del inglés: Bcl-2-interacting killer), NOXA/PMAIP-1 (del inglés: phorbol-12-myristate-13-acetate-induced protein 1) y PUMA (del inglés: $\boldsymbol{p} 53$ upregulated modulator of apoptosis), las cuales inhiben la función de las proteínas anti-apoptóticas. Estas proteínas sólo-BH3, tienen sólo un dominio $\mathrm{BH}$ de aproximadamente 26 aa, que se caracteriza por ser una $\alpha$-hélice de naturaleza anfipática que se une con alta afinidad al surco hidrofóbico de la superficie de las proteínas anti-apoptóticas (Garcia-Saez, 2012; Martinou \& Youle, 2011). En condiciones normales, estas proteínas se encuentran inactivas o en baja concentración en la célula, y tras un estímulo apoptótico, son activadas mediante cambios post-traduccionales y aumenta su expresión proteica (Shamas-Din et al, 2011). 
Proteínas anti-apoptóticas (Bcl-2, Bcl-xL, Bcl-W, A1/BFL1, MCL-1)

\begin{tabular}{|c|c|c|c|c|c|}
\hline BH4 & BH3 & BH1 & BH2 & TM & 20-40 kDa \\
\hline \multicolumn{6}{|c|}{ Proteínas pro-apoptóticas multidominio (Bax, Bak, Bok) } \\
\hline BH4 & BH3 & BH1 & BH2 & TM & 20-30 kDa \\
\hline
\end{tabular}

Proteínas pro-apoptóticas sólo-BH3 (Bid, Bim, Bad, Bik, Bmf, PUMA y NOXA)

\section{BH3}

$10-25 \mathrm{kDa}$

Figura 13. Esquema de la estructura de la familia Bcl-2. La familia $\mathrm{Bcl}-2$ está dividida en 3 grupos basados en la homología de sus dominios $\mathrm{BH}$ y sus funciones en la apoptosis. Las proteínas pro y anti-apoptóticas se caracterizan por tener 4 dominios $\mathrm{BH}$, mientras las proteínas pro-apoptóticas sólo-BH3 como su nombre lo indica solo tienen un dominio $\mathrm{BH}$. Adaptado de (Martinou \& Youle, 2011)

\subsubsection{Permeabilización de la membrana externa mitocondrial (MOMP) por Bax y Bak}

La proteína pro-apoptótica Bax tiene un peso molecular de $21 \mathrm{kDa}$ y se caracteriza por tener una forma globular formada por nueve $\alpha$-hélices ( $\alpha 1$ a $\alpha 9$ ) (Bleicken et al, 2010). Después del estímulo apoptótico y el procesamiento proteolítico de la proteína Bid por la caspasa 8 (tBid), junto con la cardiolipina (un lípido específico de la mitocondria), son esenciales para la activación de Bax (Kuwana et al, 2002). También se ha demostrado que Bim puede activar directamente a Bax a través de su interacción con los dominios $\alpha 1$ y $\alpha 6$ de esta proteína (Gavathiotis et al, 2008).

La membrana externa mitocondrial OMM (del inglés: outer mitochondrial membrane) permite el paso de moléculas menores de $5 \mathrm{kDa}$. El cambio en la MOMP, producida por la oligomerización de Bax y Bak en la membrana y la posterior formación del poro mitocondrial, induce la liberación de moléculas de mayor tamaño como por ejemplo, citocromo c (12 kDa), Smac/Diablo (27 kDa) y HtrA2/Omi (48 kDa). En condiciones normales, Bax y Bak se encuentran como monómeros inactivos en la célula; Bax está presente en el citosol mientras Bak se encuentra constitutivamente unido a la membrana mitocondrial a través de su dominio transmembrana carboxi-terminal. Una vez que se activaban ambas proteínas, Bax se transloca a la OMM y junto con Bak sufren cambios conformacionales que les permiten oligomerizar, insertarse a la membrana mitocondrial (en el caso de Bax) y 
crear el poro mitocondrial (Figura 14) (Martinou \& Youle, 2011). Para evitar la exposición de las cadenas acil hidrofóbicas de los fosfolípidos a la fase acuosa durante la formación del poro, el borde sufre una curvatura de fosfolípidos en monocapa, que conecta las dos capas de la membrana manteniendo la superficie continua (Basanez et al, 2002).

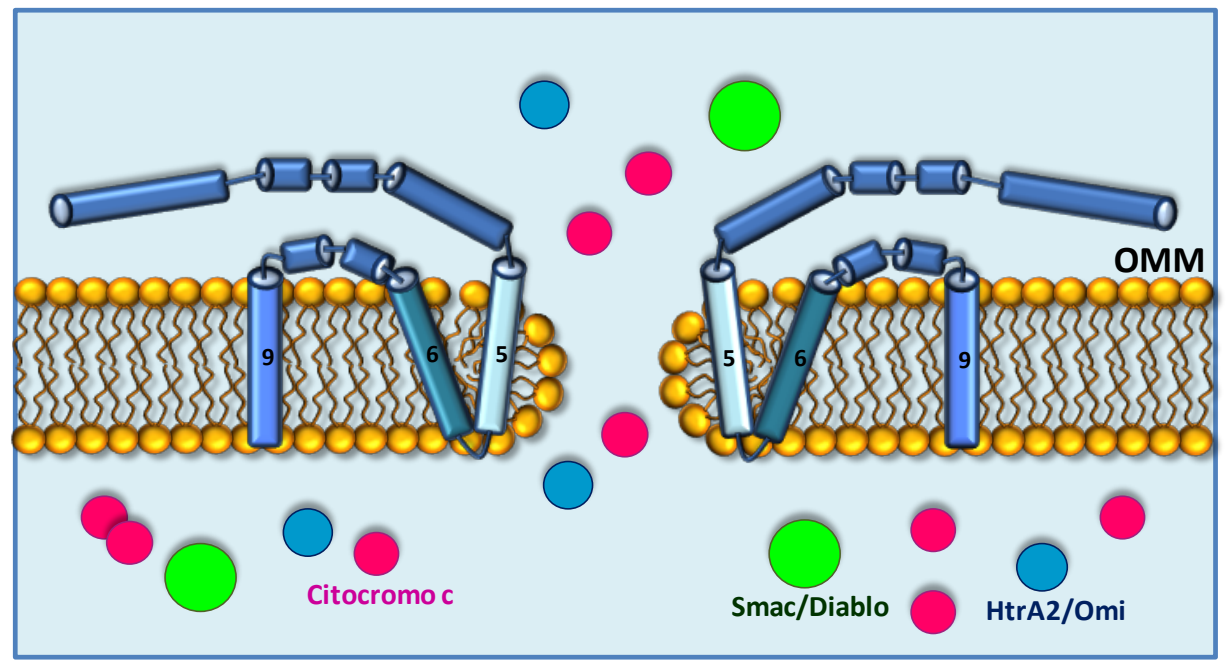

Figura 14. Formación del poro mitocondrial por Bax y Bak. Una vez Bax se inserta en la membrana externa mitocondrial y oligomeriza, induce la formación del poro lipídico. De manera similar Bak también oligomeriza formando poros sin embargo esta proteína se encuentra constitutivamente unida a la membrana mitocondrial. Tras la formación del poro mitocondrial, se liberan las proteínas encargadas de mediar la apoptosis. Adaptado de (Garcia-Saez, 2012).

\subsubsection{Activación de Bax y Bak}

Como se ha mencionado anteriormente, la activación de Bax y Bak es primordial para la MOMP, seguida de la activación de las caspasas y por último el desmantelamiento de la célula. Esta activación depende de la interacción entre las proteínas anti-apotóticas y pro-apoptóticas, así como de Bax y Bak en sí mismos.

Las interacciones entre las proteínas pro-apoptóticas y anti-apoptóticas son importantes para definir su activación y mecanismos de acción. Interesantemente no todas las proteínas pro-apoptóticas pueden interaccionar con todas las proteínas anti-apoptóticas. Por ejemplo, mientras que Bim, tBid y PUMA se unen con alta afinidad a todas las proteínas pro-apoptóticas, otras son más selectivas, como en el 
caso de Bad que solo se une a $\mathrm{Bcl}-2$, Bcl-xL y $\mathrm{Bcl}-\mathrm{W}$, o NOXA que únicamente se une a MCL1 o A1. Esto nos demuestra que este tipo de selectividad requiere aminoácidos específicos que interaccionan con una proteína en particular y no con todos los miembros de la familia, lo cual hace que la respuesta sea más específica (Figura 15) (Youle \& Strasser, 2008).

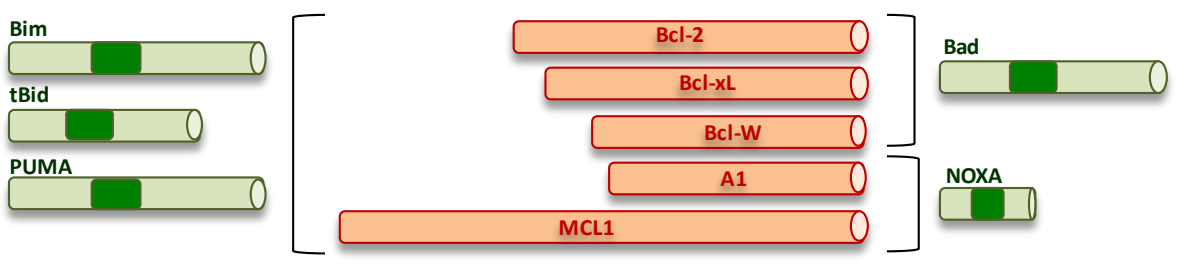

Figura 15. Unión de proteínas pro-apoptóticas sólo-BH3 a proteínas anti-apoptóticas. Bim tBid y PUMA se unen a todos los miembros del grupo de proteínas anti-apoptóticas. Sin embargo, Bad se une selectivamente a las proteínas $\mathrm{Bcl}-2, \mathrm{Bcl}-\mathrm{xL}$ y $\mathrm{Bcl}-\mathrm{W}$. Por otro lado, NOXA solo se une a las proteínas A1 y MCL1. Este tipo de interacciones ayudan a que la regulación de la señal apoptótica sea más específica dependiendo de la línea celular y los diferentes cambios durante el desarrollo celular. Se representa en verde los miembros pro-apoptóticos sólo-BH3 y en rojo las 5 proteínas anti-apoptóticas. Adaptado (Youle \& Strasser, 2008).

Para la activación de Bax y Bak se han propuesto dos modelos. El primer modelo consiste en la activación directa, la cual consiste en que las proteínas sólo-BH3 activadoras como tBid, Bim y PUMA (se ha propuesto que tiene una función similar) se unen transitoriamente a Bax y Bak iniciando su activación y posterior oligomerización en la OMM (Figura 16A) (Kim et al, 2009). De acuerdo a este mismo modelo las proteínas sólo-BH3 sensibilizadoras (Bmf, Bad, Bik y NOXA) actuarían uniéndose con alta afinidad a las proteínas anti-apoptóticas, desplazando a las proteínas sólo-BH3 activadoras (Bid, Bim y PUMA) de su unión a las proteínas antiapoptóticas, de tal forma que al quedar libres podrían activar a Bax y Bak (ShamasDin et al, 2011). El segundo modelo explicaría la activación indirecta, donde la función primordial de todas las proteínas sólo-BH3 es la unión a proteínas antiapoptóticas, evitando que alguna de ellas pueda unirse e inhibir a Bax y Bak (Figura 16B) (Happo et al, 2012). 
A

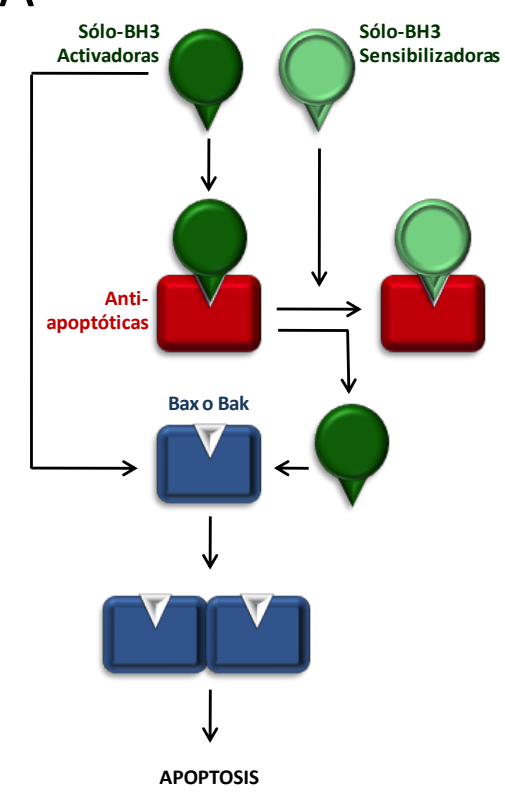

B

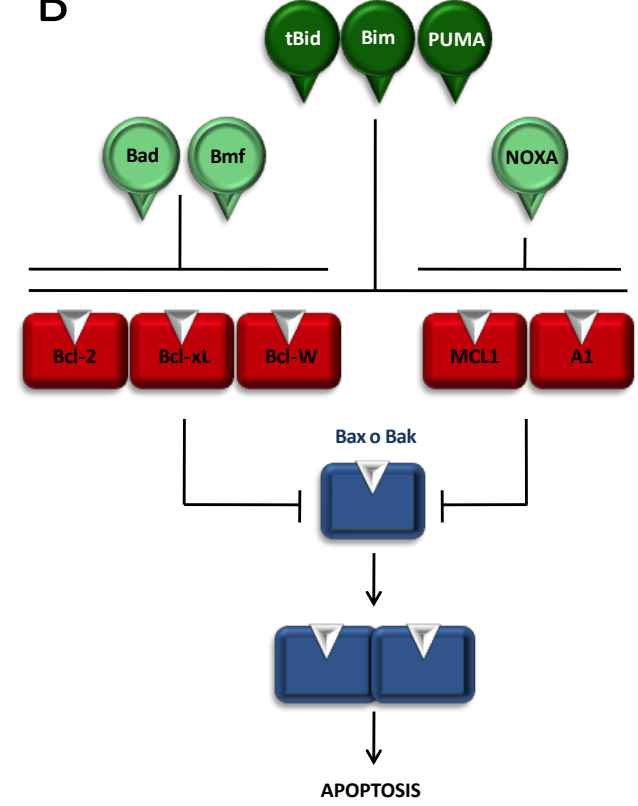

Figura 16. Modelos de activación de Bax y Bak. A. modelo de activación directa. Este modelo propone que las proteínas sólo-BH3 activadoras (tBid, Bim y PUMA) se unen transitoriamente a Bax o Bak ayudando a su activación, pero las proteínas anti-apoptóticas pueden inhibir este efecto a través de la interacción directa con estas proteínas. Por lo tanto, las proteínas sóloBH3 sensibilizadoras (Bad, Bik, Bmf y NOXA) se unen a los miembros pro-apoptóticos haciendo que se liberen las sólo-BH3 activadoras para que cumplan su función sobre Bax y Bak. B. modelo de activación indirecta. Este modelo propone que todas las proteínas pro-apoptóticas sólo-BH3 se unen a las proteínas anti-apoptóticas, de forma que previenen su unión y neutralización a las proteínas Bax y Bak.

La proteína anti-apoptótica Bcl-2 se localiza anclada al retículo endoplasmático, la membrana nuclear y la OMM a través de su dominio hidrofóbico carboxi-terminal. A diferencia de esta, las otras proteínas anti-apoptóticas Bcl-xL, Bcl-W y MCL-1 se encuentran en el citosol y se translocan a la membrana mitocondrial durante la apoptosis. Bcl-xL y Bcl-W sufren cambios conformacionales y se insertan en la OMM con el fin de interaccionar con las proteínas pro-apoptóticas evitando el desarrollo de la apoptosis. Bcl-2 también sufre cambios conformacionales durante la apoptosis. Estos cambios permiten que Bcl-2 y Bcl-xL se unan a Bax y Bak aunque estén insertados en la membrana, inhibiendo su oligomerización y promoviendo así la supervivencia de la célula (Youle \& Strasser, 2008).

MCL-1 y Bcl-xL pueden interaccionar con Bak. En el proceso de apoptosis, MCL-1 es degradado y las interacciones entre $\mathrm{MCL}-1 /$ Bak y $\mathrm{Bcl}-\mathrm{xL} / \mathrm{Bak}$ son obstaculizadas por 
las proteínas sólo-BH3 como NOXA, Bim o Bik, las cuales liberan a Bak para que pueda oligomerizarse e inducir la apoptosis (Willis et al, 2005).

Hay una gran variedad de estímulos y condiciones que conducen a la célula a la apoptosis, como por ejemplo, la radiación ionizante o medicamentos usados en quimioterapia que producen daño en el ADN, llevando a la activación de la apoptosis celular a través de la ruta relacionada con la proteína p53. Esta proteína detiene el ciclo celular en la fase G1 para darle tiempo a la célula a reparar el ADN dañado. Si este no puede ser reparado, p53 forma un pentámero que induce la apoptosis debido a que incrementa la expresión de Bax (Elmore, 2007).

\subsection{Fase de ejecución}

La vía intrínseca y extrínseca convergen en una misma vía donde su principal objetivo es la activación de las caspasas efectoras (caspasas 3, 6 y 7). La activación de estas caspasas sólo puede ser llevada a cabo por enzimas proteolíticas como caspasas iniciadoras o catepsina $G$, entre otras. Una vez activadas, comienza la destrucción de los componentes estructurales de las células (Rupinder et al, 2007). Las caspasas efectoras inducen el clivaje de diferentes proteínas encargadas de los cambios morfólogicos y bioquímicos característicos de la célula apoptótica. Entre las proteínas clivadas se encuentran: la lámina nuclear, la cual está relacionada con la condensación de la cromatina; el inhibidor de la ADNasa activada por caspasa ICAD (del inglés: Inhibitor of Caspase Activated DNase), que al ser escindido causa la liberación de endonucleasas encargadas de la fragmentación del ADN; y proteínas del citoesqueleto, tales como actina, plectina, quinasa Rho 1 y gelsolina, que producen la fragmentación de la célula y la formación de los cuerpos apoptóticos. Después de la exposición de la fosfatidilserina y azucares de la superficie, los restos de la célula son procesados por fagocitos (Igney \& Krammer, 2002).

La regulación de la apoptosis puede ser llevada a cabo por los miembros de la familia de proteínas inhibidoras de la apoptosis IAPs (del inglés: inhibitor of apoptosis proteins) las cuales son potentes reguladoras, al unirse e inhibir las caspasas. Las IAPs se caracterizan por intervenir en la señalización inflamatoria y de inmunidad, los procesos de proliferación y mitosis e intervienen en procesos de invasión celular y metástasis. También contribuyen a la regulación de la superviviencia celular mediante la inhibición de complejos de muerte como el apoptosoma (Darding \& Meier, 2012).

La apoptosis está regulada por diferentes moduladores, entre ellos se encuentran algunos iones (calcio), genes (c-myc, Bcl-2/Bax, Fas), proteínas (p53, caspasas, IAPs) e incluso orgánulos celulares (mitocondria y retículo endoplásmico). El inapropiado control de la apoptosis contribuye al desarrollo de diferentes enfermedades. Por 
ejemplo, un incremento incontrolado de la tasa de apoptosis está relacionado con el desarrollo de desórdenes neurodegenerativos, diabetes insulinodependiente, infarto al miocardio y arterosclerosis; mientras que en enfermedades autoinmunes y cáncer, la tasa de apoptosis es anormalmente baja.

\subsection{Apoptosis y cáncer}

Cuando se altera el balance entre proliferación celular y apoptosis, aumenta la posibilidad de desarrollar cáncer. En el crecimiento incontrolado de células cancerosas se van acumulando progresivamente cambios genotípicos y fenotípicos que ayudan a la invasión y metástasis de las células cancerosas. Estas células han desarrollado distintas estrategias para evadir la apoptosis, tales como alteraciones en los receptores de muerte, alteraciones en el balance de las proteínas proapoptóticas y anti-apoptóticas y disminución de la actividad de las caspasas (Wong, 2011). En el caso de la ruta extrínseca, los receptores de muerte pueden estar ausentes o escasos en algunas formas resistentes de cáncer, por ejemplo, se ha observado que en células resistentes de neuroblastoma y cáncer de colon los niveles de expresión y actividad del receptor CD95 se ven fuertemente disminuidos (Ametller et al, 2010). En cuanto a alteraciones en la ruta intrínseca, se ha observado que en células cancerosas la señal de muerte es bloqueada al romperse el balance entre proteínas anti-apoptóticas y pro-apoptóticas, concretamente la sobreexpresión de una o varias proteínas anti-apoptóticas y/o la disminuición o alteración de proteínas pro-apoptóticas afectan esta ruta. Por ejemplo, en el $85 \%$ de los linfomas foliculares humanos hay una sobre-expresión de la proteína anti-apoptótica $\mathrm{Bcl}-2$. También se ha encontrado que la sobre-expresión de $\mathrm{Bcl}-\mathrm{xL}$ confiere resistencia a diferentes tipos de tumor evitando la apoptosis (Minn et al, 1995). En algunos tumores sólidos se observa la presencia de mutaciones somáticas que inactivan el gen de Bax. Además, se han encontrado mutaciones en este gen en alteraciones hematológicas y cáncer de colon por inestabilidad microsatelital del ADN (Miquel et al, 2005). En células de cáncer pancreático se ha demostrado una sobre expresión anormal de proteínas inhibidoras de la apoptosis IAPs, también responsables de la resistencia a la quimioterapia (Lopes et al, 2007). En cuanto a la alteración en las caspasas, Devarajan et al han descrito que los niveles de ARN mensajero de la caspasa 3 se ven afectados en el cáncer de mama, ovario y cérvix, ayudando a la supervivencia de las células cancerosas (Devarajan et al, 2002). También se ha demostrado la disminución de la expresión de las caspasas 8 y 10 en cariocarcinoma (Fong et al, 2006). Estas alteraciones o defectos que se presentan en las rutas apoptóticas pueden ser una diana interesante en el desarrollo de nuevas alternativas terapéuticas contra el cáncer y demás enfermedades asociadas a este tipo de alteraciones. 


\section{LAS PROTEÍNAS QUINASAS}

La fosforilación de proteínas es una modificación postraduccional reversible, usada para la transducción de señales, mediando cambios en la conformación, localización, estabilidad y actividad de las proteínas fosforiladas. Este mecanismo regula varios procesos biológicos e interacciones importantes en la célula, tales como metabolismo, crecimiento, diferenciación, supervivencia, migración, reparación del ADN y apoptosis. Las enzimas encargadas de este proceso se llaman proteínas quinasa, que catalizan la unión covalente de un grupo fosfato a residuos de serina, treonina o tirosina de proteínas celulares específicas (Ubersax \& Ferrell, 2007). Estas enzimas se caracterizan por tener una elevada homología en el dominio quinasa, también llamado dominio catalítico, formado por una secuencia de 250-300 aminoácidos (Hanks \& Hunter, 1995). La conservación de esta secuencia indica la importancia de estas proteínas en diferentes procesos celulares, puesto que es necesario preservar su función principal, la transferencia de un grupo fosfato desde el ATP al grupo hidroxil libre de los residuos de serina, treonina o tirosina (Taylor \& Kornev, 2011). El proceso de fosforilación puede ser revertido por otras enzimas llamadas fosfatasas, encargadas de catalizar la eliminación del grupo fosfato añadido previamente por una quinasa. Se ha estimado que cerca del $30 \%$ de todas las proteínas celulares son fosforiladas por algún miembro de la gran familia de proteínas quinasa. Esta familia está formada por 518 genes que codifican sus correspondientes proteínas quinasa, que representan cerca del $2 \%$ del genoma humano (Manning et al, 2002a; Manning et al, 2002b). Existen tres subgrupos principales de quinasas basadas en la especificidad del sustrato, las serina-treonina quinasas, las tirosina quinasas y las quinasas duales que fosforilan los tres tipos de residuos. La desregulación en la actividad de las proteínas quinasa está implicada en el desarrollo de diferentes enfermedades, entre ellas, el cáncer (Ashman \& Villar, 2009; Shchemelinin et al, 2006).

En el año 2002 Manning y su grupo catalogaron filogenéticamente todas las quinasas humanas en lo que se denominó el "quinoma humano" apoyándose en las bases de datos genómicas disponibles, los ADN codificantes y las EST (del inglés: expressed sequence tags, hace referencia a secuencias cortas de ADN complementario que corresponden a parte de un ARN mensajero que se expresa en una célula)(Manning et al, 2002b). De esta forma, se identificaron un total de 518 quinasas potenciales, las cuales fueron clasificadas en ocho grupos que a su vez estaban subdivididos en familias. La clasificación realizada por Manning fue una ampliación de la investigación previamente hecha por Hanks y Hunter en el año 1995 (Hanks \& Hunter, 1995). En esta nueva clasificación se incorporan cuatro nuevos grupos, siendo uno de ellos el grupo de las caseína quinasas de tipo I (CK1), dentro del cual 
se encuentra la familia serina-treonina quinasas VRK (del inglés: Vaccinia-Related Kinases) (Figura 17).

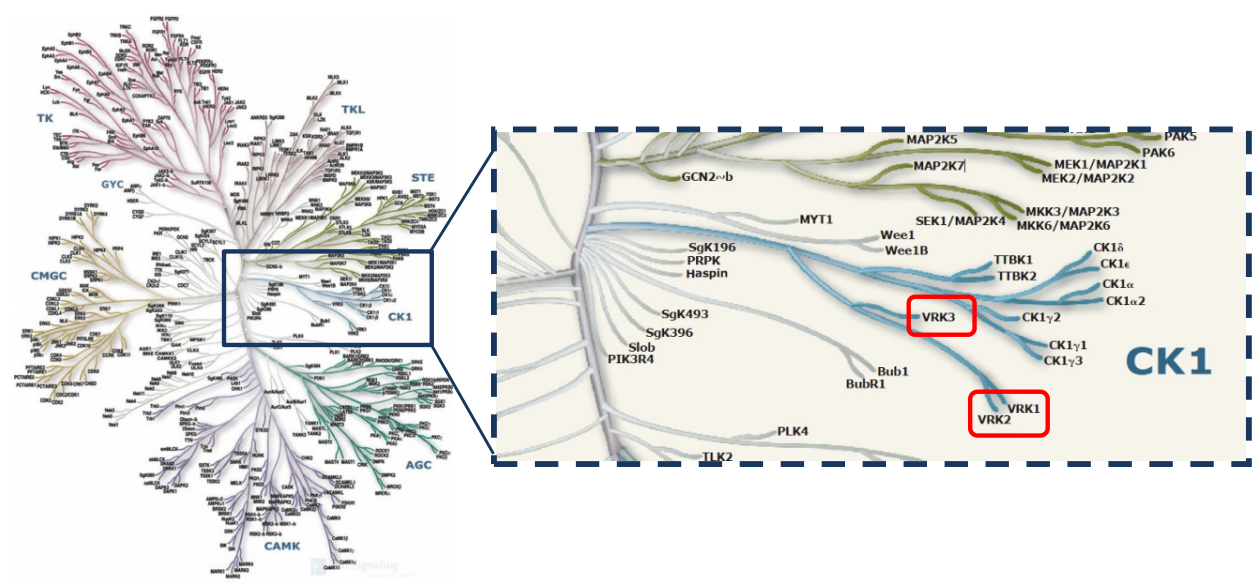

Figura 17. Representación esquemática del quinoma humano. La familia de quinasas VRK se clasifican dentro del grupo de las caseína quinasas de tipo I. Modificado de Manning et al, 2002b.

\subsection{La familia de quinasas humanas VRK}

En el ser humano, la familia de quinasas VRK está formada por tres miembros: VRK1 y VRK2, catalíticamente activos, y VRK3, una pseudoquinasa que no tiene actividad debido a sustituciones en aminoácidos críticos en el dominio quinasa (Nichols \& Traktman, 2004). VRK2 tiene dos isoformas producidas por maduración alternativa de su ARN mensajero, y se diferencian principalmente en su región carboxi-terminal (Blanco et al, 2006). Las quinasas humanas VRK1 y VRK2 fueron identificadas como EST por Nezu y colaboradores, mediante el uso de una librería de ADNc enriquecida en genes fetales de hígado para la búsqueda de genes implicados en la regulación del ciclo celular y que se expresaran en tejidos altamente proliferativos. Este grupo de quinasas recibe el nombre de Vaccinia-related kinases debido a que presentan una alta homología con la quinasa B1R del virus Vaccinia, esencial para la replicación del ADN viral (Nezu et al, 1997). Esta quinasa viral presenta un 39\% de homología con respecto a VRK1 y un 34\% con respecto a VRK2 (Nichols \& Traktman, 2004). También se observó que la expresión de VRK1 puede rescatar parcialmente la deficiencia en la replicación del ADN viral de un mutante sensible a la temperatura del virus Vaccinia deficiente en B1R (Boyle \& Traktman, 2004). Posteriormente se 
identificó la tercera quinasa llamada VRK3, también mediante búsqueda en bases de datos de librerías de ADN (Vega et al, 2003).

Se ha estudiado la presencia de ortólogos de las proteínas VRK en otros organismos. Se hipotetiza que un único gen ancestral se duplicó dos veces a lo largo de la evolución de la rama de los vertebrados, creando tres genes de la familia VRK en vertebrados y sólo quedando un único gen en invertebrados (Klerkx et al, 2009). En levaduras no existen ortólogos; sin embargo, se ha encontrado en estos organismos isoformas de la caseína quinasa tipo I, como el gen Hrr25 de Saccharomyces cerevisiae y su ortólogo el gen hhp1 de Schizosaccharomyces pombe, que por su homología en la secuencia con las VRKs, podrían ser los ancestros en levaduras. Las proteínas HRR25 y HPP1 participan en la reparación del daño en el ADN (Dhillon \& Hoekstra, 1994; Ho et al, 1997). En el nemátodo Caenorhabditis elegans existe un único ortólogo de VRK-1 codificado por el gen F28B12.3, que al ser silenciado con un ARN de interferencia específico produce un fenotipo letal en el embrión causado por defectos en la división celular (Kamath et al, 2003). La proteína VRK-1 de C. elegans es necesaria para la proliferación de células germinales, regulando la actividad de CEP-1 (ortólogo de p53) (Waters et al, 2010). Se ha descrito también como esta VRK1 fosforila a la proteína BAF (del inglés: barrier to autointegration factor), regulando su localización y participación en la formación de la envoltura nuclear (Gorjanacz et al, 2007). En la mosca de la fruta, Drosophila melanogaster, existe un ortólogo de las proteínas VRK, llamado NHK-1 (del inglés: nucleosomal histone kinase-1), capaz de fosforilar la histona H2A en mitosis (Aihara et al, 2004). También se ha descrito que NHK-1 fosforila a BAF, regulando su afinidad por la cromatina y proteínas de la membrana nuclear durante la formación del cariosoma (Lancaster et al, 2007). En el ratón, Mus musculus, al igual que en humanos existen tres ortólogos. Al comienzo, la proteína ortóloga de VRK1 fue descrita como 51PK, una quinasa nuclear con altos niveles de autofosforilación en los residuos de serina (Zelko et al, 1998). Las tres VRKs murinas se expresan durante todo el desarrollo embrionario con niveles más altos en órganos con alta tasa de proliferación como el hígado, leucocitos de sangre periférica, bazo y timo fetal. En los tejidos de ratones adultos el nivel de expresión de las tres quinasas depende del tejido celular (Vega et al, 2003). Además, existen ortólogos de las quinasas VRKs en otros organismos como el pez cebra Danio rerio, el anfibio Xenopus laevis, la rata Rattus norvegicus o el chimpancé Pan troglodytes.

\subsection{Estructura de las quinasas humanas VRKs}

La quinasa humana VRK1 está formada por 396 aminoácidos y el gen que la codifica se localiza en la región cromosómica 14q32. En la región amino se encuentra un sitio activo de unión a ATP (residuos 43-71) y el dominio serina-treonina quinasa activo (residuos 173-185). En la región carboxilo se encuentra la secuencia de localización nuclear NLS (del inglés: nuclear localization signal) (residuos 356-360). También se 
encuentra en esta región un dominio básico-ácido-básico llamado BAB (residuos 356-396) altamente conservado entre las proteínas ortólogas (Aihara et al, 2004). Esta región C-terminal no tiene homología con otras proteínas, por lo tanto, se cree que es la responsable de la regulación de VRK1 (Lopez-Borges \& Lazo, 2000). Por otro lado el gen de $V R K 2$, localizado en la región cromosómica 2 p16 codifica para dos isoformas (VRK2A y VRK2B) generadas por procesamiento alternativo de su ARN mensajero. VRK2A formada por 508 aminoácidos y VRK2B por 397 aminoácidos, presentan una secuencia idéntica hasta el aminoácido 394 a partir del cual el nuevo exón del procesamiento alternativo introduce un codón de terminación prematuro haciendo que los aminoácidos del 395 al 508 de VRK2A sean reemplazados por tres residuos VEA (valina-glutámico-alanina) al final de la secuencia de VRK2B (Blanco et al, 2006). VRK2A y VRK2B tienen en su región amino-terminal un sitio de unión al ATP (residuos 35-61) y un dominio quinasa activo (residuos 162-174). En la región carboxilo de VRK2A se encuentra una región transmembrana (RT) formada por una secuencia hidrofóbica (residuos 492-508) y dos motivos $B A B$ solapados, mientras que VRK2B no tiene esa región transmembrana y el motivo $B A B$ se encuentra truncado (Figura 18, pág. siguiente) (Blanco et al, 2006; Nichols \& Traktman, 2004).

Entre las quinasas VRK1 y VRK2 existe una homología del 44\%, que se incrementa hasta un $53 \%$ si sólo se comparan los dominios catalíticos (Nichols \& Traktman, 2004). VRK1 y VRK2 son miembros activos, con una fuerte actividad de autofosforilación, aunque VRK2 presenta una autofosforilación menor. Ambas quinasas pueden fosforilar tanto proteínas ácidas como básicas (Barcia et al, 2002; Lopez-Borges \& Lazo, 2000; Nichols \& Traktman, 2004).

Por último, la pseudoquinasa VRK3 con 474 aminoácidos es codificada por un gen localizado en la región cromosómica 19q13. Este miembro de la familia tiene poca homología con VRK1 (33\%) y VRK2 (23\%). En su región amino se encuentra una NLS y en su región carboxilo un dominio quinasa degenerado debido a sustituciones de aminoácidos claves, lo que provoca que no tenga actividad quinasa (Kang \& Kim, 2006).

La estructura tridimensional de los dominios catalíticios de VRK2 (residuos 15-330) y VRK3 (residuos 148-172) muestra una conformación bien estructurada, con un plegamiento típico de las proteínas quinasa. Una manera habitual de regular la actividad de una quinasa es mediante la fosforilación de residuos específicos en el segmento de activación, que es una región de unos 20-40 aminoácidos ubicada en el dominio catalítico. En la mayoría de quinasas existe un sitio típico de fosforilación conservado en el loop del segmento de activación. Sin embargo en algunos casos, no existe este sitio típico de fosforilación en el loop de activación, pero la quinasa igualmente es activa. Este es el caso de las proteínas VRK, que presentan una $\alpha$ hélice adicional ( $\alpha \mathrm{C} 4$ ) en el segmento de activación, lo que hace que las quinasas 
VRKs sean constitutivamente activas (Scheeff et al, 2009). En la VRK3, varios residuos de glicina en el loop-G (GXGXFG), implicado en posicionar adecuadamente el ATP para una catálisis eficiente, se encuentran degradados, siendo reemplazadas las glicinas por residuos de mayor tamaño. Estos cambios que impiden la unión del ATP así como otras modificaciones fuera del loop-G hacen que VRK3 sea una pseudoquinasa (Boudeau et al, 2006; Scheeff et al, 2009).

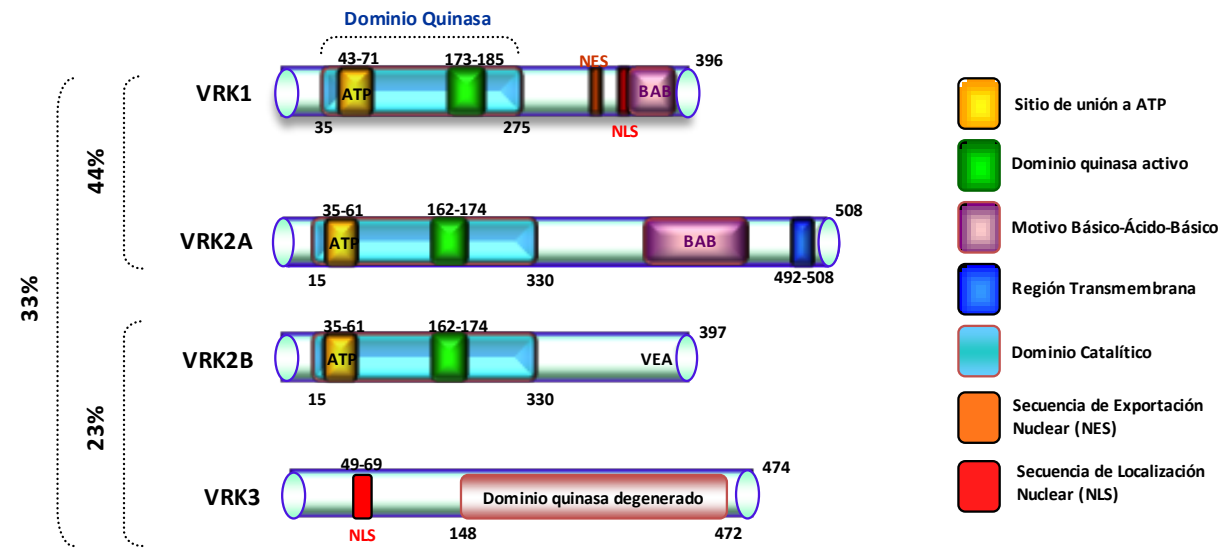

Figura 18. Representación esquemática de la estructura de las quinasas VRK. Se representan los principales motivos y dominios de los diferentes miembros de la familia VRK. VRK1 y VRK2 presentan una alta homología en la región $\mathrm{N}$-terminal, sin embargo difieren en su región Cterminal. Los porcentajes indican la homología entre los miembros de esta familia.

\subsection{La quinasa humana VRK1}

La quinasa humana VRK1 es el miembro mejor caracterizado de la familia VRK. Desde un comienzo, basándose en sus características y expresión, se relacionó la función de esta quinasa en el control de la proliferación y progresión del ciclo celular.

\subsubsection{Localización subcelular de VRK1}

VRK1 tiene una expresión ubicua en todos los tejidos, pero presenta mayor expresión en tejidos con alta tasa proliferativa, como hígado, timo, testículos fetales y líneas celulares tumorales. VRK1 se encuentra principalmente en el núcleo gracias a su NLS y es capaz de asociarse a la cromatina, aunque también está presente en el 
nucleoplasma y el nucléolo (Figura 19) (Andersen et al, 2005). Su localización subcelular varía dependiendo del tipo celular, y de las condiciones de crecimiento, detectándose en el citoplasma de algunas líneas celulares. También se ha detectado una subpoblación de VRK1 en el aparato de Golgi (Valbuena et al, 2007a). Además, se ha descrito la presencia de VRK1 en complejos de la maquinaria de iniciación transcripcional, asociados a la cromatina, junto con factores de ensamblaje $y$ proteínas histona (Guermah et al, 2006).

La quinasa humana VRK1 participa en gran variedad de procesos, tales como la correcta progresión del ciclo celular a través de la regulación de factores de transcripción, la modulación de los niveles de p53, el control del ensamblaje de la envoltura nuclear, la fosforilación de histonas o la fragmentación del aparato de Golgi.

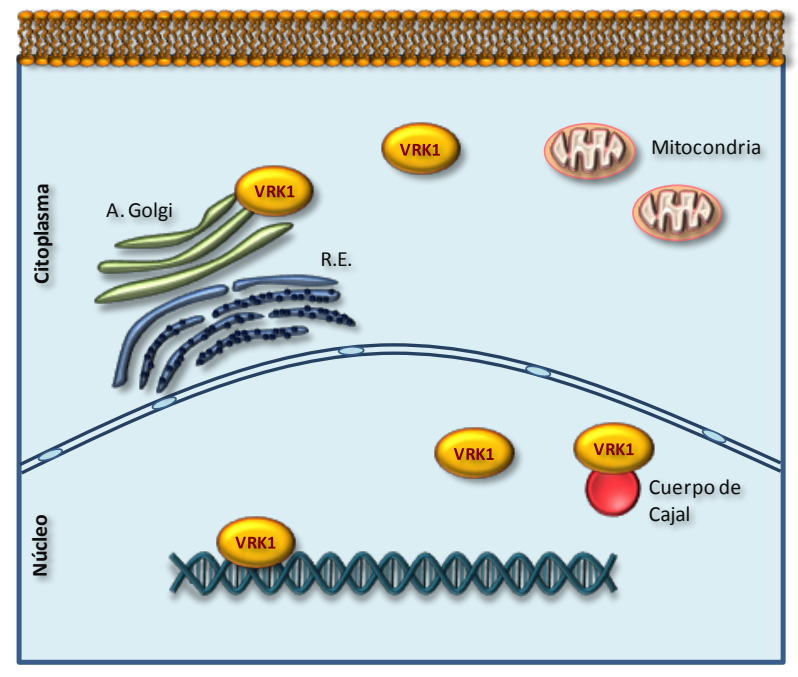

Figura 19. Localización subcelular de la quinasa VRK1. La localización de VRK1 varía dependiendo de la línea celular, principalmente se encuentra en el núcleo (cromatina y nucleoplasma). También, se han identificado subpoblaciones de VRK1 en el citoplasma y el aparato de Golgi.

\subsubsection{Implicación de VRK1 en proliferación y progresión del ciclo celular}

Distintos estudios sobre la expresión de VRK1 demuestran su implicación en el control de la proliferación y de la progresión del ciclo celular. En epitelios escamosos normales humanos, VRK1 se expresa cerca de la capa basal, donde hay mayor proliferación, y su expresión va disminuyendo a medida que las células epiteliales se 
van diferenciando, correlacionándose con el marcador de proliferación Ki67. Además, la expresión de VRK1 en tumores de cabeza y cuello de célula escamosa correlaciona positivamente con marcadores de proliferación celular como CDK2, CDK6, ciclina A, Ki67, topoisomerasa II; y negativamente con algunos inhibidores del ciclo celular como p27 o p16. Por lo tanto, se concluye que VRK1 se comporta como un marcador proliferativo (Santos et al, 2006; Valbuena et al, 2007a). Una correlación parecida se observa entre VRK1 y el marcador de células en proliferación y células madre p63, en epitelio escamoso de faringe (Valbuena et al, 2008b). Por otro lado, el silenciamiento de la expresión de VRK1 con un ARN de interferencia específico conduce también a la reducción de los niveles de ciclina D1, ciclina $A$, PCDNA y otros marcadores de proliferación, produciendo una parada del ciclo en la fase G1 (Valbuena et al, 2008b; Valbuena et al, 2011b).

En carcinoma de pulmón, los niveles de expresión de VRK1 varían en función del subtipo de tumor. Por ejemplo, en carcinomas escamosos de pulmón hay mayor expresión de VRK1 que en adenocarcinomas, produciéndose una acumulación de VRK1 en los tumores con mutaciones de p53 (Valbuena et al, 2007b). VRK1 también se encuentra sobre-expresada en sarcoma de tejidos blandos (Nishijo et al, 2009). Se ha descrito también que VRK1 podría ser un marcador de mal pronóstico en cáncer de mama. Así, tumores de mama con bajos niveles de VRK1 y bajos niveles de genes relacionados con mitosis podrían ser marcadores de buen pronóstico (Fournier et al, 2006). De manera similar, se ha observado que una elevada expresión de 16 quinasas relacionadas con ciclo celular, entre ellas VRK1, correlaciona con mal pronóstico en cáncer de mama (Finetti et al, 2008).

\subsubsection{Regulación de diferentes factores de transcripción por VRK1}

Como se ha mencionado anteriormente, VRK1 tiene una autofosforilación muy fuerte y es capaz de fosforilar tanto proteínas ácidas como básicas, característica que no comparte con el grupo de las caseína quinasas que solo fosforilan proteínas ácidas (Lopez-Borges \& Lazo, 2000; Nichols \& Traktman, 2004). Entre los sustratos que fosforila VRK1 (Figura 20, pág. 50) se encuentran varios factores de transcripción como el supresor de tumores p53, también conocido como el guardián del genoma, por su importancia en el mantenimiento de la homeostasis celular. p53 media la parada del ciclo celular con el fin de que se repare el ADN dañado. De no ser así, conduce a la célula a apoptosis. Los niveles de p53 están estrictamente controlados, solamente se incrementa su expresión en respuesta a diferentes tipos de estrés. La acumulación, estabilización y activación de p53 dependen de modificaciones postraduccionales como fosforilaciones y acetilaciones. Este factor de transcripción es fosforilado por la quinasa VRK1 en el residuo treonina 18 (Barcia et al, 2002). La fosforilación en este residuo por parte de VRK1 impide la unión de p53 con su modulador negativo Mdm2 (del inglés: mouse double minute 2) y favorece la unión 
del cofactor p300. De esta manera VRK1 estabiliza a p53 a través de Mdm2, evitando su degradación, y también mediante mecanismos independientes al incrementar la acetilación en las lisinas 373 y 382 de p53, por parte del cofactor p300 (Ferreon et al, 2009; Vega et al, 2004). Por otro lado, se ha descrito que existe un loop de autoregulación entre p53 y VRK1 (Valbuena et al, 2006), puesto que la activación de p53 induce la expresión del gen de la proteína DRAM (del inglés: damage-regulated autophagy modulator) que promueve la degradación de VRK1 por la vía proteolítica endocítica-lisosomal (Valbuena et al, 2011a). Además, se conoce que el cofactor p300 protege a VRK1 de esta degradación, debido a que es capaz de cambiar la especificidad de p53 por sus dianas de transcripción (Valbuena et al, 2008a).

Otros factores de transcripción fosforilados por la quinasa VRK1 son c-jun y ATF2 (del inglés: activating transcription factor 2), los cuales se unen a sitios AP1 (del inglés: activator protein 1) para regular la expresión génica. El factor de transcripción c-jun es regulado en respuesta a citoquinas, factores de crecimiento y señales de estrés. Este factor de transcripción es fosforilado por MAPKs (del inglés: mitogen-activated protein kinases) como ERK1/2 (del inglés: extracelular signal-regulated kinases) y JNK (del inglés: c-Jun $\mathbf{N}$-terminal kinase) (Chang \& Karin, 2001). VRK1 fosforila a c-jun en las serinas 63 y 73, promoviendo su estabilización y activación transcripcional. JNK fosforila estos mismos residuos, por lo que el efecto de ambas quinasas debe ser aditivo o cooperativo en la activación de c-jun (Sevilla et al, 2004a). En cuanto a ATF2, este factor de transcripción pertenece a la familia de factores ATF/CREB de respuesta a AMP cíclico, activa genes relacionados con crecimiento celular, diferenciación y respuesta inmune, promoviendo proliferación y oncogénesis (van Dam \& Castellazzi, 2001). ATF2 puede ser fosforilado por varias MAPKs como p38, JNK y ERK (Bhoumik \& Ronai, 2008). VRK1 fosforila los residuos serina 62 y treonina 73 de ATF, induciendo su acumulación y activación transcripcional. También las quinasas PKA (del inglés: protein kinase A) y CAMK-IV (quinasa dependiente de calmodulina IV) fosforilan estos mismos residuos de ATF (Sevilla et al, 2004b).

VRK1 también fosforila el residuo serina 133 del factor de transcripción CREB (del inglés: CAMP response element binding). Una vez que CREB y ATF2 son activados por VRK1, se incrementa la unión de estos factores de transcripción al promotor de la ciclina D1, promoviendo la expresión de esta ciclina clave en la transición de la fase G1 a fase $\mathrm{S}$ del ciclo celular. Por este motivo se relaciona la participación de VRK1 en la progresión del ciclo celular (Kang et al, 2008). 


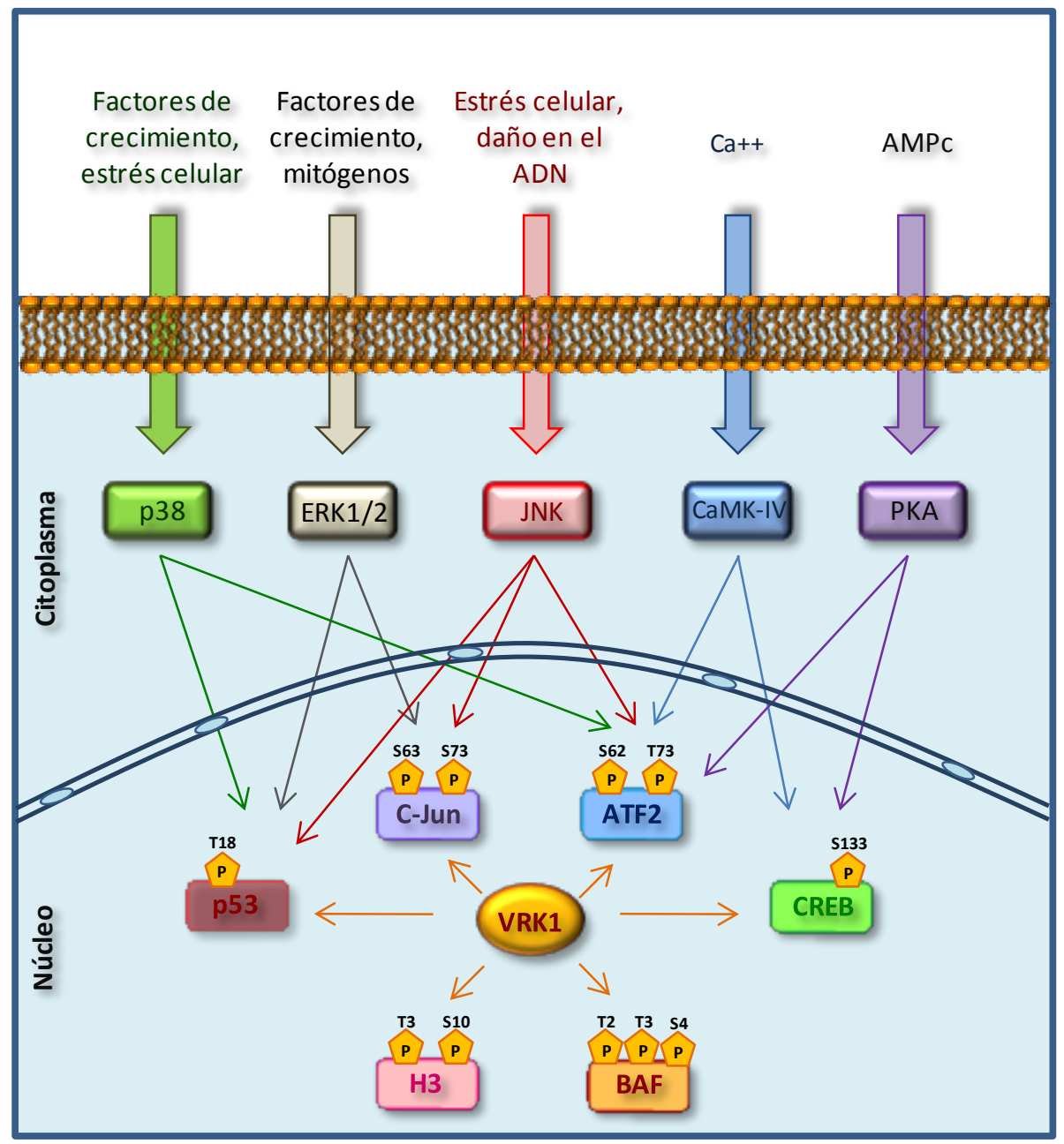

Figura 20. Diagrama de VRK1 con sus principales sustratos en comparación con otras quinasas de rutas bien caracterizadas que también fosforilan estos mismos sustratos. En la gráfica se indica los residuos fosforilados específicamente por VRK1.

\subsubsection{Fosforilación de la histona H3 por VRK1}

Las histonas sufren diversas modificaciones postraduccionales, tales como fosforilación, acetilación, metilación, ubiquitinación, sumoilación, entre otras (Baek, 2011). La mayoría de estas modificaciones son llevadas a cabo en los extremos amino y carboxilo terminales de las colas de las principales histonas $(\mathrm{H} 2 \mathrm{~A}, \mathrm{H} 2 \mathrm{~B}, \mathrm{H} 3 \mathrm{y}$ H4) para el control de procesos como la condensasión de cromatina en los cromosomas durante la mitosis y la transcripción génica (Berger, 2007). VRK1 se encuentra en la cromatina y puede fosforilar a la histona $\mathrm{H} 3$ en los residuos treonina 3 y serina 10, residuos también fosforilados por las quinasas Haspin y Aurora B, 
respectivamente (Kang et al, 2007). La fosforilación en el residuo serina 10 de la H3 se relaciona con la relajación de la cromatina y la expresión génica; mientras que en células en mitosis está relacionada con la condensación de la cromatina (Prigent \& Dimitrov, 2003). Por otro lado, la fosforilación de la treonina 3 por la quinasa Haspin media el correcto alineamiento de los cromosomas en la mitosis (Dai et al, 2005). Se ha observado que la sobre-expresión de una forma constitutivamente activa de VRK1 produce la condensación de la cromatina en células en interfase. VRK1 también puede fosforilar en menor medida a las histonas H2A, H2B y H4. Por lo tanto, VRK1 podría contribuir a la condensación de los cromosomas en la transición de la fase $G 2$ a la fase M a través de la fosforilación de las histonas (Kang et al, 2007).

\subsubsection{VRK1 y su participación en el ensamblaje de la envoltura nuclear}

La envoltura nuclear se desensambla una vez se inicia la mitosis y se vuelve a ensamblar alrededor de los cromosomas durante la telofase. De esta manera se reestablece la arquitectura del núcleo para la siguiente interfase. En este proceso participan varias proteínas, entre ellas se encuentra la proteína BAF (del inglés: barrier to autointegration factor), importante en el mantenimiento de la arquitectura nuclear. Esta proteína de $10 \mathrm{kDa}$ se une como homodímero al ADN, también se une a proteínas de la membrana nuclear interna que contienen dominios LEM (Lap2, emerin, MAN1) (Haraguchi et al, 2001). La localización de BAF varía durante el ciclo celular. Durante la interfase, se localiza en la membrana nuclear interna, donde participa en el anclaje de la cromatina a la envoltura nuclear. En mitosis, BAF se libera de su unión a la cromatina y proteínas de la membrana nuclear por lo que adquiere una localización más difusa, permitiendo la condensación de la cromatina y el desensamblaje de la envoltura nuclear al comienzo de la mitosis. En anafase, BAF se encuentra en los telómeros de los cromosomas donde juega un papel importante al reclutar proteínas de la membrana nuclear interna que median el reensamblaje de la envoltura nuclear (Haraguchi et al, 2001). VRK1 fosforila a BAF en los residuos serina 4 y treoninas 2 y 3 , que se encuentran en su región aminoterminal. Estas fosforilaciones afectan ligeramente la unión de BAF a proteínas con motivos LEM, pero afectan drásticamente la capacidad de BAF de unirse al ADN, alterando también su localización subcelular. Así, la fosforilación de BAF por parte de VRK1 hace que se libere de su unión al ADN, permitiendo la condensación de la cromatina y el desensamblaje de la envoltura nuclear. Además, la fosforilación de BAF por VRK1 es esencial tanto para la arquitectura normal de la envoltura nuclear como para la interacción de BAF con los cromosomas durante la mitosis (Molitor \& Traktman, 2014). De este modo, se postula a VRK1 como una quinasa importante en la dinámica de la envoltura nuclear (Nichols et al, 2006; Zhuang et al, 2013). 


\subsubsection{VRK1 en la fragmentación del aparato de Golgi}

Al final del ciclo celular, los orgánulos deben estar igualmente distribuidos en las dos células hijas. Concretamente, la fragmentación, dispersión y reensamblaje del aparato de Golgi durante la mitosis es un proceso donde la fosforilación reversible de proteínas tiene un efecto crítico. Las quinasas MEK1 (también conocida como MAP2K del inglés: mitogen-activated protein kinase kinase 1) y Plk3 (del inglés: pololike kinase 3) juegan un papel importante en la fragmentación del aparato de Golgi (Acharya et al, 1998; Ruan et al, 2004; Xie et al, 2004). VRK1 interacciona con Plk3, formando un complejo estable. Ambas quinasas colocalizan en el aparato de Golgi. Plk3 fosforila la región C-terminal de VRK1, específicamente el residuo serina 342. EI silenciamiento de VRK1 con un ARN de interferencia bloquea parcialmente la fragmentación del aparato de Golgi inducida por MEK y Plk3. Además, se observa un efecto similar al sobre-expresar un mutante de VRK1 sin actividad quinasa y empleando un mutante no fosforilable en serina 342 (Lopez-Sanchez et al, 2009). Estos resultados demuestran que VRK1 es necesaria para la correcta fragmentación del aparato de Golgi en la transición de la fase G2 a mitosis, situándola al final de la ruta de señalización (MEK-PIk3-VRK1).

\subsubsection{Implicación de VRK1 en neurodegeneración}

VRK1 no solo es una quinasa importante en el control del ciclo y proliferación celular, datos recientes muestran la participación de esta quinasa en el desarrollo del sistema nervioso y el mantenimiento neuronal. Se ha identificado una forma de VRK1 mutante (R358X) asociada a enfermedades neurodegenerativas. Esta proteína truncada de VRK1 generada por un codón de terminación, produce en niños con homocigosis un síndrome neurológico caracterizado por degeneración pontocerebelar espinal con ataxia, atrofia muscular espinal y en el peor de los casos conlleva a la muerte infantil. En individuos heterocigotos las consecuencias de la mutación de VRK1 R358X no se manifiestan ya que se compensan con el alelo normal (Renbaum et al, 2009). Esta mutación, al situarse dentro de la NLS de VRK1, produce una localización exclusivamente citosólica, aunque mantiene parcialmente la actividad quinasa. Por otro lado, se conoce que VRK1 interacciona con Coilina y la fosforila. Coilina es una proteína esencial para el ensamblaje de los cuerpos de Cajal en el núcleo. Esta proteína también está implicada en varias enfermedades neurodegenerativas. Existen varios residuos de Coilina fosforilados por VRK1, entre ellos la serina 184. También se ha observado que VRK1 colocaliza con Coilina en los cuerpos de Cajal, sugiriendo que estas dos proteínas pudieran tener algún efecto en este lugar (Sanz-Garcia et al, 2011). 


\subsection{La quinasa humana VRK2}

En comparación a VRK1, existe menos información sobre las funciones y regulación de esta quinasa. VRK2 se expresa ubicuamente en los tejidos, con mayores niveles de expresión en músculo esquelético, corazón, leucocitos de sangre periférica, páncreas o testículos (Nezu et al, 1997). Como se ha mencionado anteriormente, el gen de VRK2 ubicado en la región cromosómica $2 \mathrm{p} 16$ genera dos isoformas VRK2A y VRK2B, por procesamiento alternativo de su ARN mensajero (Blanco et al, 2006). La isoforma VRK2A constituida por 508 aminoácidos, se localiza anclada a membranas del retículo endoplasmático, mitocondrias y envoltura nuclear, a través de su región transmembrana de naturaleza hidrofóbica presente en su región carboxi-terminal. La isoforma VRK2B formada por 397 aminoácidos, carece de región transmembrana y por lo tanto, se encuentra libre en el citoplasma y el núcleo (Figura 21) (Blanco et al, 2006; Nichols \& Traktman, 2004). VRK2A se expresa en todas las líneas celulares estudiadas hasta el momento; mientras que VRK2B se expresa solo en determinadas líneas celulares (Blanco et al, 2006; Fernandez et al, 2010). Estudios de la expresión de VRK2 en cáncer de mama muestran una correlación inversa con la del receptor de ErbB2 y una correlación positiva con la de los receptores de estrógenos y progesterona en tumores primarios. ErbB2 se encuentra sobre-expresado en un 25$30 \%$ de los tumores de mama y es un marcador de mal pronóstico. Los tumores ErbB2 positivos tienden a disminuir o perder la expresión de VRK2. Por lo tanto, VRK2 se estaría comportando como un marcador de buen pronóstico como los receptores de estrógeno y progesterona (Fernandez et al, 2010).

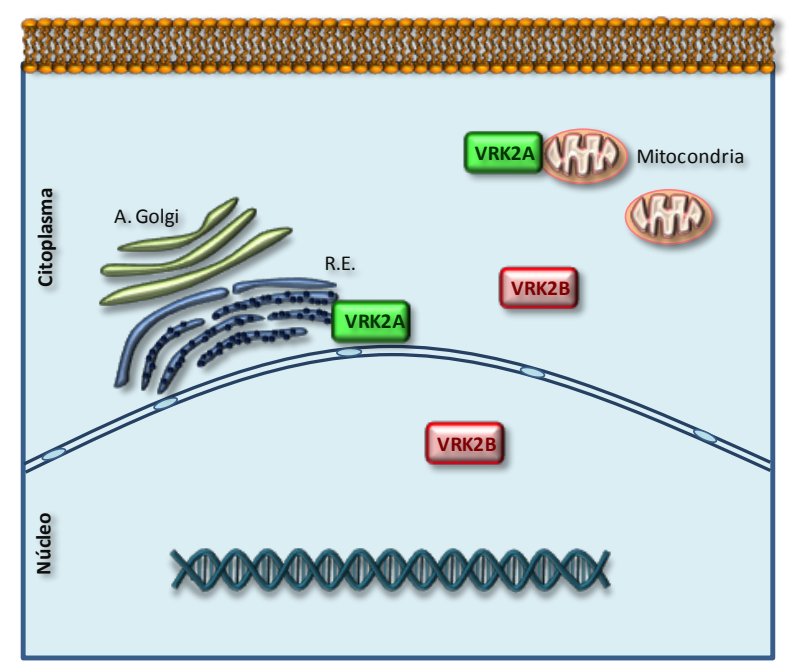

Figura 21. Localización subcelular de VRK2A y VRK2B. La isoforma VRK2A se encuentra principalmente en el citoplasma o anclada a membranas del retículo endoplásmatico y mitocondrias. Mientras, la isoforma de VRK2B se encuentra libre en el núcleo y en algunas líneas celulares también se ha detectado en el citoplasma. 
VRK2A y VRK2B tienen fuerte capacidad de autofosforilación, principalmente en residuos de treonina. Son capaces de fosforilar in vitro sustratos como la caseína, la histona H2B, la histona H3 y la proteína básica de mielina (Blanco et al, 2006; Nichols \& Traktman, 2004; Sanz-Garcia et al, 2008). Se ha observado también que la función de VRK2 tiene cierta redundancia con la de VRK1, ya que es capaz de fosforilar in vitro el residuo treonina 18 de p53 y los residuos serina 4 y treonina 2 y 3 de BAF. VRK2A y VRK2B tienden a compartir sustratos in vitro debido a la homología en su extremo catalítico hasta el aminoácido 394. Sin embargo, las grandes diferencias en su región C-terminal responsable de su localización subcelular y regulación, hacen que estas fosforilaciones no estén asociadas a una función in vivo, puesto que VRK2A tiene una localización citoplásmatica. Por lo tanto, aunque ambas isoformas fosforilen a p53 in vitro, sólo VRK2B realiza esta función in vivo, ya que puede mediar la estabilización y acumulación de p53 (Figura 22) (Blanco et al, 2006).

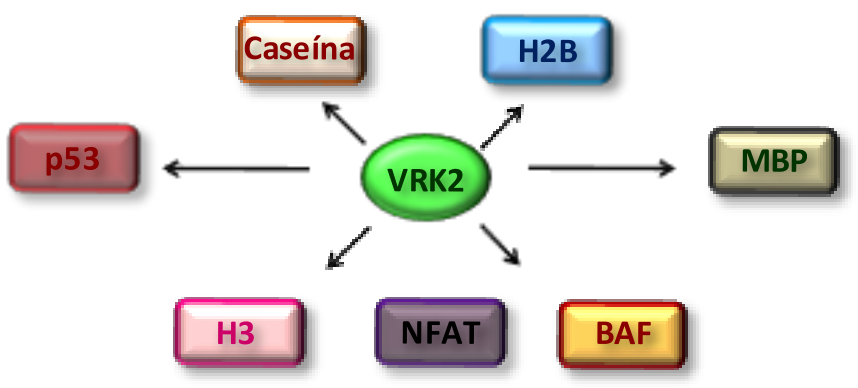

Figura 22. Sustratos de fosforilación de la quinasa VRK2. Las isoformas VRK2A y VRK2B tienden a compartir sustratos de fosforilaciónin vitro debido a su alta homología en el domino catalítico. La histona $\mathrm{H} 3$ es fosforilada en los residuos treonina 3 y serina 10 (Sanz-Garcia et al, 2008). El factor de transcripción p53 es fosforilado en el residuo treonina 18, sin embargo, sólo la isoforma nuclear VRK2B lo fosforilain vivo (Blanco et al, 2006). La proteína BAF es fosforilada en los residuos serina 4 y treoninas 2 y 3 (Nichols et al, 2006). El factor NFAT es fosforilado en el residuo serina 32 tras estimulación con PMA (Vazquez-Cedeira \& Lazo, 2012). Entre otros sustratos encontramos la caseína, la histona H2B y la proteína básica de mielina (MBP) (Nichols \& Traktman, 2004).

\subsubsection{Funciones de la quinasa humana VRK2}

Una de las funciones más estudiadas de la quinasa VRK2A es su implicación en la respuesta a estrés celular, relacionada con la activación de las MAPK. Una de estas funciones es la modulación de la transcripción génica en respuesta a estrés celular 
causada por hipoxia e interleuquina $1 \beta$ mediada por JNK (Blanco et al, 2007; Blanco et al, 2008). La proteína JNK es estimulada en condiciones de hipoxia induciendo la transcripción de genes con sitios de respuesta AP1. Por otro lado, JIP1 (del inglés: JNK-interacting protein) una proteína andamio o scaffold encargada de ensamblar el complejo MLK-MKK7-JNK (miembros de la vía MAPK) también participa en la respuesta a estímulos de estrés como hipoxia, donde JNK activa a c-jun y la transcripción dependiente de sitios AP1 (Whitmarsh et al, 2001). Adicionalmente, en esta respuesta a hipoxia también participa TAK1 (del inglés: TGF-B activated kinase). Por lo tanto, las señales de hipoxia promueven el ensamblaje de JIP1 en un complejo oligomérico que incluye TAK1, MKK7 y JNK. Tanto VRK2A como VRK2B, interaccionan establemente con JIP1. Sin embargo sólo VRK2A interacciona directamente con TAK1 y MKK7. Estas interacciones inhiben la asociación de JNK al complejo, lo que resulta en una disminución de la actividad de JNK (Blanco et al, 2007). De manera similar, VRK2A y VRK2B regulan negativamente la respuesta a interleuquina $1 \beta$ que se transmite vía TAK1-JNK (Figura 23A) (Blanco et al, 2008).

Otro papel biológico de VRK2A es su función como modulador negativo de la vía MAPK, específicamente relacionada con la señalización de ERK1/2 y la respuesta al factor de crecimiento epidérmico EGF (del inglés: epidermal growth factor). La modulación negativa de la ruta de ERK1/2 es consecuencia de la interacción directa entre VRK2A, MEK1 y la proteína de anclaje KSR1 (Figura 23B) (Fernandez et al, 2010). VRK2A contribuye a retener a una subpoblación de MEK1 y KSR1 en complejos multiproteicos de manera independiente de su actividad quinasa (Fernandez et al, 2012). 


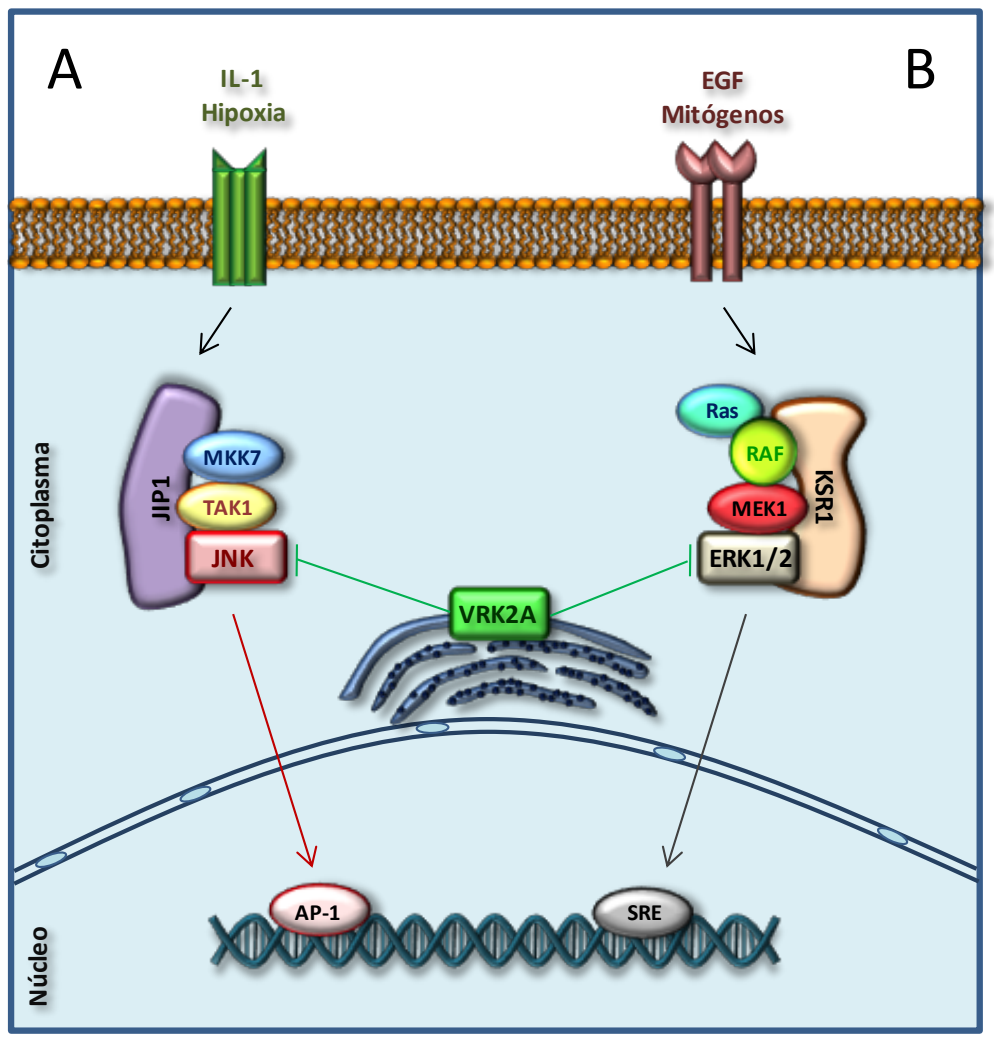

Figura 23. Funciones de la quinasa VRK2A en las rutas de señalización de MAPK. A. Esquema del mecanismo de modulación en la respuesta a IL-1, VRK2A inhibe la activación transcripcional de AP-1 a través de JNK (izquierda). B. Modulación negativa de la ruta ERK1/2 por VRK2A en respuesta a EGF o factores de crecimiento. La inhibición de VRK2A en ambas rutas es independiente de su actividad quinasa.

Además de estas interacciones, se ha descrito que VRK2 interacciona con la proteína BHRF1 del virus Epstein-Barr (Figura 24), proteína estructural y funcionalmente homóloga a la proteína anti-apoptótica $\mathrm{Bcl}-2$. Esta interacción permite incrementar la supervivencia celular tras la infección del virus (Li et al, 2006).

La activación de NFAT1 (del inglés: nuclear factor of activated $\boldsymbol{T}$ cells) y la expresión del gen de ciclooxigenasa-2 están asociadas a la invasión de las células tumorales. Recientemente, se ha descrito la primera función de VRK2 dependiente de su actividad quinasa. VRK2A y VRK2B fosforilan el residuo serina 32 de NFAT, tras estimulación con PMA (forbol 12-miristato 13-acetato, análogo del diacilglicerol) más ionomicina, potenciando la actividad de este factor de transcripción. Esta activación de NFAT por VRK2 incrementa la transcripción del promotor de ciclooxigenasa-2. Además, el silenciamiento de VRK2A con un ARN de interferencia 
causa una disminución de los niveles de ARN mensajero y los niveles de proteína de la ciclooxigenasa-2, sin afectar los niveles de expresión de NFAT. También, se observó que el silenciamiento de VRK2 reduce la invasión de células tumorales (Vazquez-Cedeira \& Lazo, 2012).
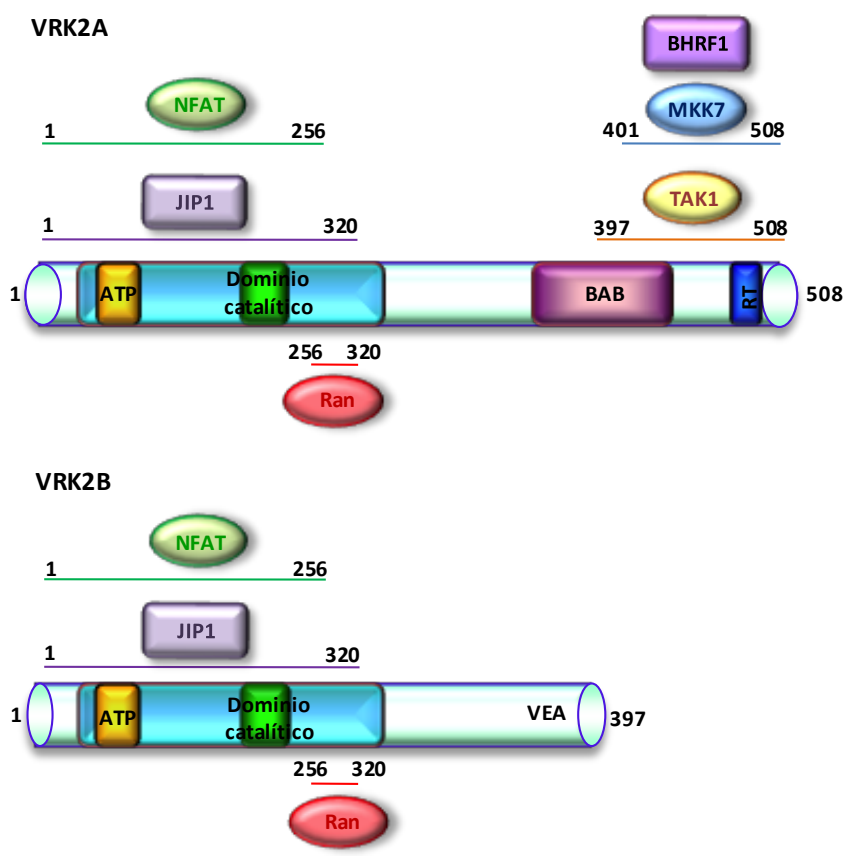

Figura 24. Esquema de proteínas que interaccionan con VRK2A y VRK2B. Se enseñan las regiones de interacción de VRK2A y VRK2B con JIP y NFAT (región N-terminal), TAK1 y BHRF (región C-terminal) y Ran (aminoácidos 256-320).

VRK2 al igual que VRK1, también podría estar implicada en enfermedades neurológicas. Diversos estudios sugieren que malformaciones de la corteza cerebral observada en algunos pacientes puede ser causado por alteraciones en el gen de VRK2, ubicado en la región 2p16 (Chandler et al, 2006). Además, recientemente se ha relacionado polimorfismos en el gen de VRK2 con el riesgo de sufrir esquizofrenia (Steinberg et al, 2011). 


\subsection{Regulación de las quinasas humanas VRKs}

Aunque existe información detallada acerca del papel biológico de la quinasa humana VRK1, se conoce menos acerca de su regulación. La regulación de la expresión, localización y actividad de VRK1 es necesaria para una correcta respuesta a diferentes estímulos y condiciones celulares. La presencia de mitógenos y factores de crecimiento en el suero regulan la expresión de VRK1, puesto que la ausencia de suero en los medios de cultivo celular produce la disminución en los niveles de VRK1 y tras la adición del suero, incrementan nuevamente (Valbuena et al, 2008b). Por otro lado, se ha descrito que los factores de transcripción E2F1 y Myc pueden activar la expresión de VRK1 a través de su promotor (Kang et al, 2008; Santos et al, 2006).

Las modificaciones postraduccionales de proteínas también son importantes para la regulación de su localización subcelular y actividad. Las quinasas VRK1 y VRK2 tienen alta actividad de autofosforilación (Lopez-Borges \& Lazo, 2000), que puede ayudar a la estabilidad de la proteína, ya que la quinasa inactiva es más inestable que la quinasa silvestre y su vida media es menor (Valbuena et al, 2008b). Al parecer la región C-terminal de VRK1 está implicada en la regulación de esta quinasa, se ha determinado mediante ensayos in vitro, un residuo de autofosforilación en esta región (treonina 355), aunque aún no se conoce si es relevante para la localización y actividad de esta quinasa (Barcia et al, 2002). Además, se ha descrito también que el residuo serina 355 de VRK1 puede ser fosforilado por la quinasa $\mathrm{PKC} \delta$, regulando negativamente su actividad quinasa (Park et al, 2011). En condiciones de proliferación, VRK1 fosforila sustratos importantes para la progresión del ciclo celular como CREB, histona H3 o BAF. Sin embargo en condiciones de daño en el $A D N$, VRK1 sería fosforilada por PKC $\delta$ contribuyendo a la parada del ciclo y posterior muerte celular dependiente de p53 (Park et al, 2011). Por otro lado, se realizó un estudio para identificar potenciales residuos de fosforilación en VRK1 por otras quinasas como ATM y ATR en respuesta a luz ultravioleta, donde se identificó a la treonina 378 de la región C-terminal como posible residuo de fosforilación (Stokes et al, 2007). Además, se ha demostrado que la actividad quinasa de VRK1 se incrementa tras la exposición de las células a radiación ionizante, luz ultravioleta o drogas como doxorrubicina o etopósido que producen daño en el ADN (Sanz-Garcia et al, 2012; Valbuena et al, 2011a).

La interacción estable entre proteínas también puede ayudar a la regulación de la actividad quinasa. A través de técnicas proteómicas se identificó a la GTPasa Ran (del inglés: Ras-related nuclear) como una proteína que interacciona con VRK1, VRK2A y VRK2B. Ran se comporta como un inhibidor de la actividad quinasa de estas VRKs, ya que si estas quinasas se unen a RanGTP se encuentran activas, mientras, que si interaccionan con RanGDP están inactivas (Sanz-Garcia et al, 2008). Por otra parte, se conoce que la interacción en interfase de VRK1 con la macroH2A1, una variante 
de la histona H2, evita la fosforilación de VRK1 sobre la H3 y sobre BAF, sin afectar la actividad de autofosforilación de VRK1 (Kim et al, 2012b).

En cuanto a estudiar la posibilidad de inhibir la actividad quinasa de las proteínas VRK, se realizó un estudio sobre la sensibilidad de VRK1 y VRK2 a diferentes inhibidores de quinasas y metales (Barcia-Sanjurjo et al, 2013). Se evidenció que las proteínas VRK son poco sensibles a inhibidores de otras quinasas. Además, VRK1 y VRK2 presentaron un patrón de sensibilidad diferente, lo cual sugiere que se podría desarrollar inhibidores específicos para cada uno de los miembros de esta familia (Vazquez-Cedeira et al, 2011).

\subsection{La pseudoquinasa humana VRK3}

Como se mencionó anteriormente, el gen de la pseudoquinasa humana VRK3 se encuentra en el cromosoma 19q13, el cual codifica una proteína de 474 aminoácidos carente de actividad quinasa. VRK3 tiene una localización subcelular principalmente nuclear debido a la presencia de una NLS en su región amino-terminal (Nichols \& Traktman, 2004; Vega et al, 2003). Su falta de actividad quinasa y la conservación del plegamiento del dominio catalítico hacen pensar que esta proteína actúe como proteína de anclaje para la formación de complejos proteicos (Scheeff et al, 2009). Así, VRK3 forma un complejo con VHR y ERK1/2 en el cual la actividad fosfatasa de VHR es estimulada por VRK3, disminuyendo los niveles de fosforilación de ERK1/2. Por lo tanto, VRK3 puede regular negativamente la ruta de señalización de ERK1/2 (Kang \& Kim, 2006). Además, se ha descrito que la estimulación con PMA activa ERK y a su vez se incrementan los niveles de expresión de VRK3, de tal forma que se establece un mecanismo de retroalimentación negativa donde ERK1/2 regula positivamente la expresión de su regulador negativo VRK3 (Kang \& Kim, 2006). Por otro lado, VRK3 no está relacionada directamente con procesos proliferativos, ya que su expresión es similar en tejidos con alta tasa de proliferación como en tejidos con baja tasa proliferativa (Kang \& Kim, 2008).

\subsection{Ratones Knock-out de VRK1 y VRK2}

Se han estudiado ratones hipomórficos, donde se ha realizado una inserción en el gen de VRK1 que produce una expresión de esta proteína de tan sólo el 15\% en comparación con los ratones silvestres. Se observó que tanto machos como hembras son viables pero estériles. La esterilidad es resultado de un defecto progresivo en la capacidad proliferativa de las células espermatogénicas, que conlleva a la falta de mitosis y meiosis en las células reproductoras en el testículo del ratón (Choi et al, 2010; Wiebe et al, 2010). En los demás tejidos no se observó un efecto drástico por el silenciamiento parcial de esta quinasa, por lo que se cree que puede existir cierta 
redundancia con los otros miembros de la familia VRK. Por otra parte, se estudió la relación de la gametogénesis con la quinasa VRK1 en ratones con esta inserción que impide la expresión de esta quinasa. Se evidenciaron diferencias entre machos y hembras: los machos al comienzo eran fértiles pero progresivamente sufrían alteraciones en la espermatogénesis que resultaban en esterilidad; mientras que las hembras eran totalmente estériles y presentaban defectos durante el desarrollo de los oocitos (Schober et al, 2011). Además, se han descrito alteraciones en la foliculogénesis en ovarios deficientes de VRK1 (Kim et al, 2012a).

Por otro lado, se ha estudiado el efecto de la alteración del gen de VRK2 en ratones. Se compararon ratones con una mutación recesiva que altera los genes de VRK2 y pog, que se transcriben en dirección opuesta. Se observó cómo los ratones doble knock-out VRK2-/- pog-/- presentaban una esterilidad más severa que los ratones sólo knock-out pog-/-. Por tal motivo, VRK2 podría estar desempeñando un papel parecido a VRK1 en cuanto al proceso de espermatógenesis (Lu \& Bishop, 2003). 


\section{OBJETIVOS}

1. Estudiar el papel de la quinasa humana VRK1 en la respuesta al daño en el ADN y su efecto sobre proteínas clave en los focos de reparación como NBS1 y MDC1.

2. Investigar la respuesta de la quinasa humana VRK1 en la reparación de roturas de doble cadena del $A D N$, de manera independiente de la quinasa ATM.

3. Analizar el efecto y la relación de la quinasa humana VRK2 en el proceso de apoptosis. 
MATERIALES $Y$

MÉTODOS 



\section{Técnicas de manipulación del ADN}

\subsection{Obtención y purificación de ADN plasmídico de E. Coli}

La técnica de lisis alcalina descrita por Birnboim y Doly (Birnboim \& Doly, 1979), fue utilizada para el aislamiento de ADN plasmídico a partir de $E$. coli, esta técnica se fundamenta en la alcalinización de las células de E. Coli con $\mathrm{NaOH}$ (Hidróxido de sodio) en presencia de un detergente aniónico como el SDS (Sodium Dodecyl Sulfate), provocando la lisis celular, la desnaturalización del ADN cromosómico y proteínas, y posteriormente la liberación de los plásmidos. Para la obtención de ADN plasmídico con mayor grado de pureza se realizó la técnica de extracción con fenolcloroformo, la cual consiste en una desproteinización mediante lavados con fenol:cloroformo y, posteriormente, la precipitación del ADN plásmidico con etanol. Para la extracción de ADN plasmídico a pequeña escala se realizó el protocolo indicado por el sistema comercial High Pure Plasmid Isolation Kit (Roche mannheim Germany). La extracción de ADN plasmídico a gran escala se realizó mediante el uso del sistema comercial JETStar The Novel Plasmid Purification System de GENOMED. Las extracciones del ADN plasmídico fueron llevadas a cabo según las indicaciones de los fabricantes.

\subsection{Cuantificación de ADN plasmídico}

La concentración final del ADN plasmídico obtenido se cuantificó midiendo la absorbancia de la muestra a 260nm en el espectrofotómetro (Hitachi U-2001). Para calcular la pureza de los ácidos nucleicos se empleó el cociente de las absorbancias A260/A280 que debe estar entre 1.8 y 2.0 para el ADN purificado. Posteriormente, se confirmó la concentración de ADN mediante electroforesis en geles de agarosa al $1 \%$.

\subsection{Electroforesis de ácidos nucleicos en gel de agarosa}

La separación de los fragmentos de ADN se realizó de acuerdo a su tamaño y carga neta (dada por los grupos fosfatos del ADN), mediante electroforesis en geles de agarosa al $1 \%$ en tampón TAE (Tris-acetato $40 \mathrm{mM}$ y EDTA $1 \mathrm{mM}$ ), que mantiene el $\mathrm{PH}$ cercano a 8 durante el corrido, lo cual es de gran importancia puesto que la migración del ADN depende de las cargas negativas de los fosfatos y de los iones cargados en el medio. Dado que los ácidos nucleicos tienen carga negativa migrarán hacia el polo positivo al ser sometidos a un campo eléctrico. Se utilizó como marcador de peso molecular el $A D N$ Ladder $1 K b$ de Promega. Para la visualización del ADN (bandas) se añadió bromuro de etidio $(0,5 \mu \mathrm{g} / \mathrm{mL})$ al tampón de electroforesis, un agente que se intercala entre las bases nitrogenadas del ADN y 
que al ser expuesto a luz ultra-violeta emite fluorescencia. Las bandas correspondientes a los fragmentos de ADN y los marcadores de peso molecular fueron captados con una cámara digital acoplada al analizador de imagen Gel Doc ${ }^{\mathrm{TM}}$ 2000 de Bio-Rad e impresas en papel térmico. Para determinar el tamaño de la banda se comparó su migración con respecto a los marcadores de peso molecular.

\subsection{Generación de vectores de ADN recombinante}

Las construcciones de ADN recombinante diseñadas en el laboratorio fueron generadas mediante la inserción de secuencias de ADN codificante en los vectores de interés mediante la digestión de fragmentos de ADN con endonucleasas de restricción (Promega o Fermentas) y posterior ligación con la enzima T4 DNA-Ligasa (Promega). Las construcciones obtenidas fueron transformadas en bacterias competentes de $E$. coli como las DH5 $\alpha$ o BL21DE3, las cuales fueron cultivadas en medio LB (Luria Broth) con su antibiótico correspondiente (ampicilina $10 \mu \mathrm{g} / \mathrm{mL} \mathrm{o}$ kanamicina $25 \mu \mathrm{g} / \mathrm{mL}$ ) e incubadas a $37^{\circ} \mathrm{C}$ toda la noche. Posteriormente se observó el crecimiento de las colonias transformadas debido a que llevan incorporado un gen de resistencia en el plásmido de interés. La verificación de las construcciones de ADN se llevó a cabo por análisis o digestiones con enzimas de restricción y posterior secuenciación, para confirmar la secuencia correcta mediante su alineamiento en los programas Chromas y DS-GENE.

\subsection{Transformación de plásmidos en E. Coli}

Los plásmidos de ADN recombinante fueron transformados en bacterias $E$. coli competentes $\mathrm{DH} 5 \alpha$ ó BL21DE3, para la expresión de ADN plasmídico o proteínas recombinantes respectivamente. La transformación se realizó mediante la técnica de choque térmico. Así, una vez descongeladas las bacterias, se añadió una pequeña cantidad de ADN a transformar (50-100 ng), mezclando homogéneamente e incubando en hielo $\left(4^{\circ} \mathrm{C}\right)$ durante 30 minutos. Posteriormente se procedió al choque térmico a $42^{\circ} \mathrm{C}$ durante 30 segundos y se pasó rápidamente al hielo $\left(4^{\circ} \mathrm{C}\right)$. Se añadió $1 \mathrm{~mL}$ de medio de cultivo $\mathrm{LB}$ y se incubó a $37^{\circ} \mathrm{C}$ en agitación durante 1 hora. A continuación, las bacterias se sembraron en placas de Petri de LB-agar con su correspondiente antibiótico de selección para el crecimiento de las bacterias que expresan los genes de resistencia al antibiótico utilizado. Las placas se incubaron a $37^{\circ} \mathrm{C}$ durante toda la noche y al día siguiente se repican las colonias individuales para la verificación de la correcta inserción del plásmido por secuenciación. Las colonias positivas se guardaron a $-80^{\circ} \mathrm{C}$ en medio LB con antibiótico y glicerol estéril al $30 \%$ (v/v) como crioprotector. 


\subsection{Mutagénesis dirigida}

Para realizar mutaciones en nucleótidos puntuales, se siguió el protocolo recomendado por el sistema comercial "QuickChange Site-Directed Mutagenesis" (Stratagene, USA). Para llevar a cabo la PCR se preparó una reacción que contenía 20ng del plásmido utilizado como ADN molde, 125 ng de cada oligonucleótido diseñado con la mutación puntual de interés, $0.2 \mathrm{mM}$ de dNTPs (Roche), tampón de PCR (KCl 100 mM, (NH4)2SO4 100 mM, Tris-HCl 200 mM pH 8.8, MgSO4 20 mM, 1\% Tritón X-100, BSA $1 \mathrm{mg} / \mathrm{mL}$ ) y una unidad de la enzima FPU turbo DNA polimerasa (Stratagene) en un volumen final de $50 \mu \mathrm{L}$. Antes de la adición de la polimerasa, la reacción fue incubada a $95^{\circ} \mathrm{C}$ durante 10 minutos para la desnaturalización de las hebras del ADN. Tras la adición de la enzima se llevaron a cabo 16 ciclos de $95^{\circ} \mathrm{C}$ durante 30 segundos, seguidos de 1 minuto a $55^{\circ} \mathrm{C}$ y una elongación durante 22 minutos a $68^{\circ} \mathrm{C}$. El ADN sustrato fue eliminado mediante la incubación del producto de la PCR con la enzima Dpnl (Fermentas), la cual actúa específicamente sobre secuencias metiladas y hemimetiladas, resultando así seleccionadas sólo las copias mutantes. El producto de PCR se transformó en cepas de E. Coli DH5 $\alpha$, seleccionando las colonias transformantes por su resistencia específica al antibiótico, los plásmidos fueron aislados y purificados con el método indicado en High Pure Plasmid Isolation Kit (Roche, Mannheim Germany) y posteriormente analizados por secuenciación para confirmar la presencia del nucleótido mutado. Los oligonucleótidos utilizados se pueden ver en la tabla 3 (pág.79-80).

\section{Técnicas de manipulación de proteínas}

\subsection{Purificación de proteínas de fusión con GST}

Esta técnica permite la expresión y purificación de proteínas de fusión a GST (Glutatión-S-Transferasa) a gran escala a partir de cepas de E. coli BL21DE3, previamente transformadas con los plásmidos pGEX-4T-GST donde han sido clonadas las proteínas de interés. Estos plásmidos presentan un promotor lac que permite inducir su expresión químicamente con lactosa o un análogo, como el isopropil $\beta$-D-tiogalactopiranósido (IPTG).

Los clones de bacterias con los plásmidos correspondientes se crecieron durante toda la noche a $37^{\circ} \mathrm{C}$ en medio LB con el antibiótico de selección ampicilina (50 $\mu \mathrm{g} / \mathrm{mL}$ ). Al día siguiente se realizó una dilución 1:10 del preinóculo en medio selectivo fresco (LB+ampicilina) y se incubó a $37^{\circ} \mathrm{C}$ en agitación durante 1-2 horas aproximadamente, hasta alcanzar una densidad óptica a $600 \mathrm{~nm}$ de 0.6-0.8. En ese momento, el cultivo se encuentra en fase exponencial por lo que se puede inducir la expresión de la proteína al añadir al medio 0,2 mM de IPTG (Boehringer Mannheim). El cultivo siguió en crecimiento a $37^{\circ} \mathrm{C}$ en agitación durante $2-4$ horas. 
Transcurrido este tiempo, el cultivo fue centrifugado a $8000 \mathrm{rpm}$ durante 10 minutos. Se retiró el sobrenandante y se resuspendió el pellet bacteriano en buffer de lisis (PBS frío con 1\% Tritón X-100, 0,2 $\mathrm{mg} / \mathrm{mL}$ Lisozima, 1mM PMSF, 5mM DTT, 10 $\mu \mathrm{g} / \mathrm{mL}$ Aprotinina y $10 \mu \mathrm{g} / \mathrm{mL}$ Leupeptina). La suspensión se sonicó a $4^{\circ} \mathrm{C}$ en baja potencia realizando 5 pulsos de 10 segundos cada uno con intervalos de 10 segundos sin sonicar, utilizando el sonicador Misonic XL2010. Tras 30 minutos a $4^{\circ} \mathrm{C}$, se centrifugó a $15000 \mathrm{rpm}$ durante 30 minutos. El sobrenadante contiene las proteínas solubles y en mayor proporción la proteína de fusión expresada; por lo tanto, en esta parte del procedimiento se recomienda recoger una alícuota del pellet y de la fracción soluble para luego verificar en un gel si nuestra proteína permanece en la fracción soluble. Posteriormente la fracción soluble se incubó con 100-200 $\mu$ de la resina Glutathion Sepharose $4 B$ beads (GE Healthcare) durante toda la noche a $4^{\circ} \mathrm{C}$ en agitación suave. Esta resina tiene alta afinidad por el GST que se encuentra fusionado a la proteína de interés. Transcurrido el tiempo de incubación se lavó la resina 5 veces con PBS $1 X$ más inhibidores de proteasas a 1800 rpm durante 3 minutos a $4^{\circ} \mathrm{C}$. Para finalizar se dejó la misma cantidad de PBS que de resina (50\%) y para guardar la proteína a $-20^{\circ} \mathrm{C}$ se añadió glicerol al $20 \%$. Para eluir la proteína de fusión de la resina se utilizó una solución de $10 \mathrm{mM}$ de glutatión reducido en $50 \mathrm{mM}$ Tris- $\mathrm{HCl}$ pH 8 a $4^{\circ} \mathrm{C}$, durante 4-12 horas, en agitación orbital y se recogió el sobrenadante con la proteína eluída tras centrifugar 3 minutos a $2000 \mathrm{rpm}$. Se verificó la purificación de la proteína mediante electroforesis SDS-PAGE seguida de tinción con azul de Coomassie o Western blot. La concentración proteica se determinó por colorimetría mediante BIORAD protein assay (Bio-Rad), utilizando BSA para la recta patrón.

Algunas proteínas unidas a la resina glutatión sefarosa se separaron de su epítopo GST por digestión con trombina (10 unidades/mg proteína de fusión), durante 16 horas a temperatura ambiente. A continuación se centrifugó a 2000 rpm durante 5 minutos y se guardó el sobrenadante que contiene la proteína purificada.

\subsection{Electroforesis en geles SDS-PAGE}

La separación de proteínas en función de su tamaño se llevó a cabo en condiciones desnaturalizantes, mediante electroforesis vertical en geles SDS-PAGE (del inglés: Sodium Dodecylsulfate - polyacrilamide Gel Electrophoresis). EI SDS (dodecilsulfato sódico) es un detergente aniónico que desnaturaliza y se une a las proteínas confiriéndoles una carga negativa uniforme debido a sus grupos sulfato, de tal forma que la propia carga de la proteína queda enmascarada por las múltiples moléculas de SDS. Así, las proteínas tienen una relación carga:masa uniforme, de manera que migran hacia el polo positivo en función de su masa molecular. El tamaño de los poros del gel depende de la concentración de acrilamida utilizada y esta a su vez depende de la proteína a analizar. Para resolver proteínas con pesos moleculares 
entre 30-100 kDa se emplearon preferentemente geles del 10\% de acrilamida, para proteínas entre $15-30$ kDa geles del $12.5 \%$ y para proteínas mayores de 120 kDa geles del 7.5\%. Para la preparación del gel separador (resolving) se utilizó 5-15\% acrilamida, 0.13-0.4\% bis-acrilamida en un tampón de 0,375 M Tris- $\mathrm{HCl}$ pH 8.8 y 3,5 mM SDS. Encima de este gel separador se preparó el gel concentrador (stacking) del $4.8 \%$ acrilamida, $0.128 \%$ bis-acrilamida en tampón $0,125 \mathrm{M}$ Tris- $\mathrm{HCl}$ pH 6.8 y 3,5 mM SDS. Para la solidificación de los geles se añadió un agente iniciador de la polimerización como el persulfato de amonio y un catalizador de la formación de los radicales libres como el TEMED ( $N, \mathrm{~N}, \mathrm{~N}^{\prime}, \mathrm{N}^{\prime}$ - tetrametiletilenodiamina).

Las muestras de proteínas se procesaron con tampón de carga $(62,5 \mathrm{mM}$ Tris- $\mathrm{HCl}$ pH $6.8,10 \%$ glicerol, $2.3 \%$ SDS, $0.1 \%$ azul de bromofenol y $5 \% \beta$-mercaptoetanol) y se hirvieron durante 5 minutos. El gel se corrió en condiciones desnaturalizantes en tampón de carrera adecuado ( $25 \mathrm{mM}$ Tris- $\mathrm{HCl}, 200 \mathrm{mM}$ glicina y 1,7 mM SDS). Como marcadores de peso molecular se utilizaron marcadores preteñidos Precision Plus Protein $^{\text {TM }}$ Standards Dual Color (Bio-Rad).

\subsection{Tinción con Azul de Coomassie}

Para la visualización de las proteínas en geles de poliacrilamida se utilizó la tinción de azul de Coomassie, compuesta por 0.5\% Coomassie brilliant blue R250 (Merck), 50\% metanol y $10 \%$ ácido acético glacial. Se añadió esta solución a los geles y se dejó en agitación durante 5 minutos. Posteriomente, los geles fueron desteñidos con solución de destinción ( $50 \%$ metanol, $10 \%$ ácido acético glacial) en agitación hasta que las bandas de las proteínas se visualizaron correctamente. Para finalizar los geles se transfirieron a papel whatman $3 \mathrm{M}$ y se secaron con el secador de geles (Bio-Rad) durante 2 horas a $80^{\circ} \mathrm{C}$.

\subsection{Transferencia húmeda y Western blot de extractos proteicos}

Después de la electroforesis SDS-PAGE, las proteínas fueron transferidas de los geles de poliacrilamida a las membranas de PVDF Immobilon-P o Immobilon-FL (Millipore) mediante transferencia húmeda según Towbin (Towbin et al, 1979), para la realización de western blot y posterior detección de las proteínas con anticuerpos específicos. El tampón de transferencia utilizado fue $25 \mathrm{mM}$ Tris- $\mathrm{HCl}, 19,2 \mathrm{mM}$ glicina y $10-20 \%$ metanol. La concentración de metanol varía según el peso molecular de las proteínas de interés (a mayor tamaño de la proteína menor concentración de metanol). La transferencia se realizó durante 1-1,5 horas a 80-90 V o durante toda la noche a $40 \mathrm{~V}$.

Para llevar a cabo el Western blot, la membrana de transferencia se bloqueó durante 1 hora a temperatura ambiente o toda la noche a $4^{\circ} \mathrm{C}$ en agitación en $5 \%$ de leche en polvo desnatada resuspendida en el tampón TBS-T $(25 \mathrm{mM}$ Tris- $\mathrm{HCl}$ pH 8, $50 \mathrm{mM}$ 
$\mathrm{NaCl}, 2,5 \mathrm{mM} \mathrm{KCl}$ y $0.1 \%$ Tween-20). A continuación, la membrana se incubó con el anticuerpo primario necesario para detectar la proteína de interés, a la dilución recomendada en TBS-T (tabla 4, pág. 81-82) durante 1-2 horas a temperatura ambiente o toda la noche a $4^{\circ} \mathrm{C}$. Los anticuerpos de Cell Signaling fueron incubados en TBS-T con $5 \%$ de BSA según lo recomendado por la casa comercial. Después de la incubación se realizaron 3 lavados durante 10 minutos cada uno con TBS-T en agitación. Los anticuerpos secundarios Goat Anti-Mouse IgG, DyLight ${ }^{T M} 680$ y/o Goat anti-Rabbit Ig-G, DyLight ${ }^{T M} 800$ (Thermo scientific) se incubaron con la membrana a la dilución adecuada (1:10000) durante 1 hora, y después de los 3 lavados con TBS-T, la membrana fue escaneada con LI-COR Odyssey Infrared Imaging System para detectar la fluorescencia emitida por las proteínas.

En algunos casos, el anticuerpo secundario utilizado estaba conjugado con peroxidasa (ECL anti-mouse IgG, horseradish peroxidase-linked species-specific whole antibody de Amersham o anti-rabbit IgG (whole molecule) peroxidase conjugate de SIGMA-ALDRICH), por lo que después de la incubación con la membrana durante 1 hora se realizaron 3 lavados con TBS-T y se detectó la luminiscencia tras la incubación con el reactivo ECL Western Blotting Detection Reagents (Ammersham Biosciences) y exponiendo las membranas a películas de rayos $\mathrm{X}$ (Fujifilm).

\subsection{Tinción con rojo Ponceau}

En determinadas ocasiones las proteínas transferidas a las membranas de PVDF se visualizaron con tinción rojo Ponceau. Las membranas fueron incubadas durante 1015 minutos con la solución compuesta de $0.2 \%$ Ponceau S (ácido 3-Hidroxi-4[2-sulfo4-(4-sulfo-fenilazo) fenilazo]-2,7-naftalenodisulfónico), 3\% ácido sulfosalicílico, 3\% ácido trifluoroacético y $1 \%$ ácido acético. Tras la incubación, las membranas se lavaron con agua hasta la visualización de las bandas.

\section{Cultivo de líneas celulares}

Las líneas celulares utilizadas para este trabajo así como el medio de cultivo usado para el correcto crecimiento de estas células se especifican en la tabla 5 (pág. 83). Las líneas celulares se cultivaron en flasks (BD Falcon) en un incubador a $37^{\circ} \mathrm{C}, 5 \%$ de $\mathrm{CO}_{2}$ y $98 \%$ de humedad relativa. Los medios de cultivos (DMEM, RPMI, McCoy's) fueron suplementados con $10 \%$ de $F B S$ (suero fetal bovino), $2 \mathrm{mM}$ de L-glutamina, y los antibióticos penicilina (50 unidades $/ \mathrm{mL}$ ) y estreptomicina $(50 \mu \mathrm{g} / \mathrm{mL})$. Para levantar las células de los flasks se utilizó tripsina-EDTA. Los medios de cultivo fueron obtenidos de SIGMA-ALDRICH y el suero y los suplementos fueron obtenidos de GIBCO-life technologies. Las líneas celulares se observaron con un microscopio óptico invertido Zeiss Axiovert 25. 


\section{Transfecciones transitorias de ADN en células eucariotas en cultivo monocapa}

Para la sobre-expresión de proteínas se llevaron a cabo transfecciones con plásmidos de ADN codificante de expresión eucariota (tabla 6, pág. 84-85). Las células fueron sembradas en placas de Petri (BD Falcon) 24 horas antes de la transfección a una densidad adecuada, de tal forma que al momento de la transfección estuvieran entre el 50 y $70 \%$ de confluencia. Las cantidades de ADN transfectado se especifican en cada experimento, la concentración final de ADN se mantuvo constante mediante la adición de los microgramos necesarios de un vector vacío.

\subsection{Transfección con JetPEI}

Este tipo de transfecciones se realizaron con el reactivo comercial JetPEI ${ }^{T M}$ (Polyplus transfection) siguiendo las instrucciones del fabricante. Este polímero catiónico (polietilenimina) compacta el $A D N$ en el interior de partículas cargadas positivamente (formando complejos) que se adhieren a los proteoglicanos cargados negativamente de la superficie celular. Estos complejos una vez unidos a la superficie celular son introducidos al interior de la célula por endocitosis. EI ADN se resuspendió en un volumen determinado de $\mathrm{NaCl} 150 \mathrm{mM}$ y a continuación se añadió 1 volumen de $\mathrm{NaCl} 150 \mathrm{mM}$ en el que se había resuspendido el reactivo JetPEI ( $2 \mu \mathrm{L}$ de reactivo por $\mu \mathrm{g}$ de ADN a transfectar). Posteriormente esta mezcla se incubó durante 30 minutos a temperatura ambiente, luego se añadió por goteo a las células sembradas en las placas de Petri y se homogeneizó con el medio de cultivo.

\subsection{Transfección con Lipofectamine}

Para llevar a cabo experimentos de supresión génica de una proteína mediante ARN de interferencia se utilizó el reactivo Lipofectamine ${ }^{T M} 2000$ (Invitrogen), con el fin de conseguir mayor eficiencia de transfección de los oligonucleótidos. Lipofectamine ${ }^{T M}$ contiene subunidades lipídicas que pueden formar liposomas en ambientes acuosos. Estos liposomas de naturaleza catiónica forman complejos con los ácidos nucleicos (cargados negativamente), con el fin de evitar la repulsión electrostática de la membrana celular (también de carga negativa), facilitando la fusión de estos complejos con la membrana celular y su incorporación a la célula. El reactivo de lipofectamine se diluyó en un volumen de Opti-MEM (GIBCO-life technologies) y tras 10 minutos de incubación se añadió a un volumen de Opti-MEM en el que previamente se habían resuspendido los oligonucleótidos de ARN de interferencia a una concentración de 100-200 nM. Transcurridos 30 minutos de incubación, la mezcla se añadió sobre las células que habíamos cultivado en medio sin antibiótico. 


\subsection{Supresión de la expresión génica mediante ARNi}

Para realizar la supresión de la expresión del gen de VRK1 y el gen de VRK2 se usaron los dúplex de ARN de interferencia especificados en la tabla 3 (pág. 79-80) de la casa comercial Dharmacon RNA Technologies. En paralelo se utilizó como control negativo un dúplex de ARN carente de diana en las células humanas, ON-TARGET plus SiControl Nontargeting SiRNA de la misma casa comercial. Para la transfección transitoria de estos ARN de interferencia se empleó el reactivo lipofectamine ${ }^{\mathrm{TM}} 2000$.

\section{Obtención de extractos proteicos de células en cultivo}

Para la obtención de extractos proteicos totales a partir de células en cultivo, se lisaron las células con tampón de lisis suave $(50 \mathrm{mM}$ Tris- $\mathrm{HCl}, \mathrm{pH} 8.0,150 \mathrm{mM} \mathrm{NaCl}$, 1\% Tritón X-100 y $1 \mathrm{mM}$ EDTA) ó bien con tampón de lisis RIPA (150 mM NaCl, 1,5 $\mathrm{mM} \mathrm{MgCl}_{2}, 10 \mathrm{mM} \mathrm{NaF}, 4$ mM EDTA, 50 mM Hepes, 1\% Tritón X-100, 0.1\% SDS, 10\% Glicerol) a los cuales se les añadió inhibidores de proteasas (1 mM PMSF, $10 \mu \mathrm{g} / \mathrm{mL}$ de aprotinina, $10 \mu \mathrm{g} / \mathrm{mL}$ de leupeptina) y fosfatasas ( $1 \mathrm{mM}$ de ortovanadato de sodio y $1 \mathrm{mM}$ de NaF). Después de incubar 20 minutos en hielo, los extractos fueron centrifugados a $13200 \mathrm{rpm}$ a $4^{\circ} \mathrm{C}$ durante 20 minutos. Se recuperó la fracción soluble y el pellet fue descartado. A continuación, se cuantificó la cantidad de proteína obtenida por el método de Bradford. Para la detección de proteínas endógenas y sobre-expresadas se resolvió una cantidad igual de extracto proteico (25-50 $\mu \mathrm{g})$ para todos los puntos a comparar mediante electroforesis SDS-PAGE y posteriormente se realizó Western blot.

\section{Cuantificación de proteínas}

Para la cuantificación de proteínas se utilizó el método de Bradford. Este método se basa en el empleo de un colorante, el azul brillante G-250 Coomassie, el cual se une a las proteínas produciendo un cambio de color pardo a rojo-azulado cambiando su máximo de absorción de 465 a $595 \mathrm{~nm}$. Se utilizó el reactivo comercial Bio-Rad Protein assay (Bio-Rad) y se realizó una curva patrón usando la proteína BSA (seroalbúmina bovina).

\section{Ensayos de interacción entre proteínas}

\subsection{Ensayos de coinmunoprecipitación}

Las inmunoprecipitaciones se realizaron a partir de 1.5 - $3 \mathrm{mg}$ de extracto proteico total, lisado con el tampón indicado para cada experimento. Estos extractos, en un volumen final de $1 \mathrm{~mL}$, fueron previamente incubados con $30 \mu \mathrm{L}$ de la resina 
equilibrada GammaBind Plus Sepharose (GE Healthcare) durante 1 hora a $4^{\circ} \mathrm{C}$ en rotación, con el fin de eliminar del extracto todo lo que se pueda unir inespecíficamente a la resina. A continuación, se retiró la resina por centrifugación suave y se incubaron los extractos con el anticuerpo específico a la concentración adecuada (generalmente entre 1:50 a 1:500) durante 4-6 horas o toda la noche, en rotación a $4^{\circ} \mathrm{C}$. Después de la incubación con el anticuerpo se añadieron $40 \mu \mathrm{L}$ de resina (GammaBind Plus Sepharose) previamente equilibrada mediante lavados con tampón de lisis a $4^{\circ} \mathrm{C}$ a $2600 \mathrm{rpm}$. Esta mezcla (extracto+anticuerpo+resina) se incubó durante 4 horas o toda la noche a $4^{\circ} \mathrm{C}$ en rotación, con el fin de que el anticuerpo utilizado en la inmunoprecipitación se una a la resina. Tras este tiempo, se realizaron entre 3 y 5 lavados suaves de la resina con tampón de lisis a 2600 rpm a $4^{\circ} \mathrm{C}$. Posteriormente la resina fue procesada con tampón de carga, de tal forma que las proteínas inmunoprecipitadas fueron analizadas por electroforesis SDS-PAGE y Western blot. En los experimentos de coinmunoprecipitación se utilizó como control negativo una inmunoprecipitación realizada con un anticuerpo inespecífico.

\subsection{Ensayos de Pull-Down}

Los experimentos de pull-down se llevaron a cabo con el fin de precipitar proteínas fusionadas a GST expresadas exógenamente en células eucariotas y detectar si existe o no interacción con otras proteínas endógenas o sobre-expresadas. Las células que sobre-expresan las proteínas fusionadas a GST fueron lisadas en tampón de lisis suave (50 mM Tris- $\mathrm{HCl}, \mathrm{pH} 8.0,150 \mathrm{mM} \mathrm{NaCl}, 1 \%$ Tritón X-100 y 1 mM EDTA), siempre en presencia de inhibidores de proteasas y fosfatasas (1mM PMSF, 10 $\mu \mathrm{g} / \mathrm{mL}$ de aprotinina, $10 \mu \mathrm{g} / \mathrm{mL}$ de leupeptina, $1 \mathrm{mM}$ de ortovanadato de sodio $\mathrm{y}$ $1 \mathrm{mM}$ de NaF). Se utilizó entre 1.5 y $3 \mathrm{mg}$ de extracto proteico para cada punto del experimento. El extracto se incubó con la resina equilibrada GammaBind Plus Sepharose durante 1 hora a $4^{\circ} \mathrm{C}$ en rotación, con la intención de eliminar proteínas que se pudieran unir de manera inespecífica a la resina. A continuación se retiró la resina por centrifugación suave (GammaBind Plus Sepharose) y el extracto se incubó durante toda la noche con $40 \mu \mathrm{L}$ de la resina "Glutathion Sepharose $4 B$ beads" (GE Healthcare) previamente equilibrada mediante lavados con tampón de lisis a 2600 rpm a $4^{\circ} \mathrm{C}$. Al día siguiente se realizan entre 3 y 5 lavados de la resina con tampón de lisis a $2600 \mathrm{rpm}$ a $4^{\circ} \mathrm{C}$. Finalmente, las muestras con la resina se procesan con tampón de carga para ser analizadas por electroforesis SDS-PAGE y Western blot. En estos experimentos se incluye como control negativo un punto en el que se precipita la proteína GST, para descartar interacciones inespecíficas. 


\section{RT-PCR cuantitativa en tiempo real}

Esta técnica permite la amplificación y cuantificación con gran exactitud y fiabilidad de una molécula concreta de ARN, para la cual se han diseñado oligonucleótidos específicos que amplifican el fragmento del cual se desea conocer su nivel de expresión. Para ello mediante el uso de la enzima transcriptasa reversa se transforma la molécula de $A R N$ en su correspondiente molécula de ADN y luego dicha molécula de ADN se amplifica mediante PCR (reacción en cadena de la polimerasa). El número de copias del oligonucleótido diana al inicio de la reacción se puede cuantificar con gran precisión a través del ciclo umbral (Ct). El Ct es el número de ciclos necesarios para que se produzca un aumento de fluorescencia asociada al ADN amplificado, con respecto a la señal de base y es inversamente proporcional a la cantidad inicial de moléculas molde.

Las células crecidas en placas de Petri fueron lavadas varias veces con PBS 1X frío. A continuación, se extrajo el RNA total utilizando el kit RNeasy Mini Kit (Qiagen) siguiendo las instrucciones del fabricante. Las muestras fueron lisadas y homogenizadas en un tampón desnaturalizante (RLT) que contiene tiocianato de guanidina que inactiva las ribonucleasas asegurando la purificación del ARN intacto. Posteriormente se añadió 1 volumen de etanol al 70\%, y esta mezcla se pasa a las columnas con membranas de silica gel, donde el ARN total se une a estas membranas y los posibles contaminantes son descartados a través de lavados continuos. Por último el ARN total fue eluído en $30 \mu \mathrm{L}$ de agua RNAse free. El ARN total purificado se cuantificó y analizó mediante el sistema Bioanalyzer 2100 nanolab chip (Agilent Technologies). Para la reacción de RT-PCR cuantitativa en tiempo real se utilizaron: $100 \mathrm{ng}$ de ARN total diluído a $50 \mathrm{ng} / \mu \mathrm{l}$, el kit QuantiTec SYBR Green $R T$-PCR kit (Qiagen), un termociclador iCycler (Bio-Rad) y los primers específicos para cada caso (tabla 3, pág. 79-80). La fluorescencia emitida por el fluorocromo SYBR Green, asociada al ADN amplificado, fue cuantificada y analizada en el software de iCycler. Para cada experimento, los niveles de ARN específico se normalizaron respecto a los niveles de ARN de la GAPDH (Gliceraldehído-3-fosfato deshidrogenasa) determinados para cada muestra, como control interno para corregir la variabilidad.

\section{Determinación de la actividad transcripcional con genes reporteros de luciferasa}

Este tipo de ensayos se emplea para estudiar la regulación de genes, situando el gen reportero de la luciferasa tras el promotor en estudio.

El sistema de valoración de la actividad transcripcional de un factor de transcripción, se basa en la transfección de células con un plásmido que contiene un gen de la luciferasa bajo el control de un promotor en concreto. La unión de factores de 
transcripción adecuados a los sitios de unión en el promotor permitirá la transactivación del gen reportero de la luciferasa con la consiguiente síntesis de la proteína luciferasa. En los experimentos se empleó el plásmido pGL-3-Bax-Luc (-687318) de M. Oren (Weitzman Institute, Rehovot, Israel). 48 horas después de la transfección, se lisaron los extractos en tampón de lisis suave y se procedió a medir la actividad luciferasa con el kit Dual-Luciferase reporter assay system (Promega). Este método se basa en la capacidad de la luciferasa de catalizar la oxidación de la luciferina usando ATP $+\mathrm{Mg}^{2+}$ para dar lugar a la oxiluciferina que emite luz. Esta emisión de luz a $556 \mathrm{~nm}$ fue cuantificada en el luminómetro Lumat LB 9507 (Berthold Technologies). Los ensayos de luciferasa se realizaron por triplicado y cada experimento se repitió un mínimo de 3 veces. Los resultados fueron analizados estadísticamente mediante el test de $t$-Student.

\section{Inmunofluorescencia y microscopía confocal}

Con el objetivo de detectar los niveles de expresión y localización subcelular de proteínas endógenas y sobre-expresadas en células en cultivo se llevaron a cabo ensayos de inmunofluorescencia. Las células se sembraron sobre cubreobjetos de vidrio estériles, los cuales en algunas ocasiones cuando se utilizó la línea celular HEK293T se trataron con poli-L-Lisina (SIGMA-ALDRICH) al 0.01\% para mejorar la adhesión de las células al cristal. Transcurridas las horas de crecimiento (dependiendo del ensayo), las células fueron lavadas con PBS $1 \mathrm{X}$ y fijadas con paraformaldehído al 3\% en PBS $1 X$ durante 30 minutos a temperatura ambiente. A continuación, se añadió glicina $(200 \mathrm{mM})$ durante 15 minutos a temperatura ambiente para reducir los grupos aldehídos libres que pudieran quedar después de la fijación, puesto que estos pueden reaccionar con aminas y proteínas generando productos fluorescentes. Posteriormente se permeabilizaron las células con PBS 1X + Tritón $\mathrm{X}-100$ al $0.2 \%$ en PBS $1 \mathrm{X}$ durante 30 minutos, y finalmente, las células fueron bloqueadas con PBS $1 \mathrm{X}+\mathrm{BSA} 1 \%$ y azida $2 \mathrm{X}$ durante 1 hora a temperatura ambiente o durante toda la noche a $4^{\circ} \mathrm{C}$. En la mayoría de los experimentos se detectaron dos proteínas a la vez. Para ello, se incubaron los anticuerpos primarios de manera secuencial, el primer anticuerpo primario se diluyó en PBS $1 \mathrm{X}+\mathrm{BSA} 1 \%$ y azida $2 \mathrm{X}$ a la concentración adecuada y se incubó durante 2 horas a temperatura ambiente 0 durante toda la noche a $4^{\circ} \mathrm{C}$. Tras tres lavados con PBS $1 \mathrm{X}$ se incubó el segundo anticuerpo primario de diferente origen al primero en las mismas condiciones. Siempre se realizaron 3 lavados con PBS $1 X$ tras la incubación de los anticuerpos para eliminar los restos de anticuerpo libre. Los anticuerpos secundarios marcados con los fluorocromos de cianina Cy2 (Cy ${ }^{T M}$ 2-conjugated AffiniPure Goat anti-Rabbit/antiMouse IgG $(\mathrm{H}+\mathrm{L})$ de Jackson ImmunoResearch) y Cy3 $\left(\mathrm{Cy}^{\mathrm{TM}}\right.$ 3-conjugated AffiniPure Goat anti-Rabbit/anti-Mouse I $g \mathrm{G}(\mathrm{H}+\mathrm{L})$ de Jackson ImmunoResearch) se diluyeron a 1:1000 en PBS $1 \mathrm{X}+\mathrm{BSA} 1 \%$ y se incubaron durante 1 hora a temperatura ambiente 
siempre en oscuridad. El resto del proceso se continúa evitando la exposición de las muestras a la luz para preservar los fluoróforos. Tras los lavados, los núcleos celulares se tiñeron con DAPI (4', 6'-diamidino-2-fenilindol) diluido en PBS $1 \mathrm{X}$ durante 15 minutos a temperatura ambiente. Después de los 3 últimos lavados con PBS $1 \mathrm{X}$, los cubreobjetos se montaron sobre portaobjetos con MOWIOL ${ }^{\circledR}$ 4-88 (Calbiochem). La localización subcelular de las proteínas se analizó mediante microscopía confocal en el microscopio Leica TCS SP5 y el software usado para la captura y análisis de las imágenes fue LAS AF Lite.

\section{Ensayos de actividad quinasa}

La actividad serina-treonina quinasa se analizó mediante ensayos de fosforilación in vitro utilizando las proteínas quinasa GST-VRK recombinantes expresadas en E. Coli. Se emplearon como sustrato proteínas recombinantes purificadas o bien proteínas inmunoprecipitadas con la resina GammaBind Plus Sepharose. Para analizar la actividad quinasa de VRK1 y VRK2A/B se usó un tampón específico para caseín quinasas (20 mM Tris- $\mathrm{HCl} \mathrm{pH} \mathrm{7.5,} 5 \mathrm{mM} \mathrm{MgCl} 2,0,5 \mathrm{mM}$ DTT y $150 \mathrm{mM} \mathrm{KCl}$ ), con $5 \mu \mathrm{M}$ de ATP y $5 \mu \mathrm{Ci}(0,1 \mu \mathrm{M})$ de $\left[\gamma^{-}{ }^{32} \mathrm{P}\right]$ ATP en un volumen final de 30-40 $\mu \mathrm{L}$. En algunos casos se utilizó como sustrato la histona $\mathrm{H} 3$ de Xenopus Laevis (Upstate) y también la proteína recombinante GST-p53 que corresponde al fragmento de p53 que comprende los aminoácidos 1-85. Las reacciones de fosforilación se incubaron durante 30 minutos a $30^{\circ} \mathrm{C}$ en agitación (800 rpm) en un Thermomixer Compact (Eppendorf). En los experimentos donde se determinó la actividad quinasa de la proteína VRK endógena se utilizó la quinasa inmunoprecipitada de células A549 en las mismas condiciones usadas para las reacciones con la quinasa recombinante.

Tras el tiempo de incubación las reacciones de fosforilación fueron procesadas con tampón de carga $(62,5 \mathrm{mM}$ Tris- $\mathrm{HCl}$ pH 6.8, 10\% glicerol, 2.3\% SDS, 0.1\% azul de bromofenol y $5 \% \beta$-mercaptoetanol) e incubadas a $100^{\circ} \mathrm{C}$ durante 5 minutos. Las proteínas fosforiladas se analizaron por electroforesis SDS-PAGE y se transfirieron a membranas de PVDF Immobilon-P (Millipore). Para detectar las bandas radiactivas, se expusieron las membranas a películas de rayos $\mathrm{X}$ (Fujifilm) durante varios minutos $\mathrm{u}$ horas. Como controles se utilizaron las bandas de proteínas teñidas con rojo Ponceau o detectadas con anticuerpos específicos en el Western blot.

\section{Fraccionamiento subcelular para separación de citosol y mitocondrias}

Para la separación de las fracciones de citosol y mitocondrias, las células fueron lavadas dos veces con PBS frío $1 \mathrm{X}$ y posteriormente se centifugaron a $2300 \mathrm{rpm}$ durante 5 minutos a $4^{\circ} \mathrm{C}$. Se descartó el sobrenadante y se resuspendió el precipitado celular en buffer de lisis (Pre-tampón de lisis ( $25 \mathrm{mM}$ Tris- $\mathrm{HCl}(\mathrm{pH} 6.8)$, 
$250 \mathrm{mM}$ sucrosa, $1 \mathrm{mM}$ EDTA), $0.1 \mathrm{mM}$ benzamidina, digitonina 0.05\%, DTT $1 \mathrm{M}$, PMSF $100 \mathrm{mM}$ y $1 \mu \mathrm{g} / \mathrm{mL}$ de leupeptina, pepstatina y aprotinina). A continuación, se centrifugó a $13000 \mathrm{rpm}$ durante 3 minutos. Se separó el sobrenadante (fracción citosólica) del precipitado (fracción mitocondrial y nuclear), este último fue resuspendido nuevamente en el pre-tampón de lisis y posteriormente centrifugado a $13000 \mathrm{rpm}$ durante 10 segundos a $4^{\circ} \mathrm{C}$, obteniéndose la fracción nuclear en el precipitado. Se separó el sobrenadante (pre-fracción mitocondrial) y se centrifugó nuevamente a $13000 \mathrm{rpm}$ durante 10 segundos a $4^{\circ} \mathrm{C}$. El precipitado obtenido (fracción mitocondrial) se resuspendió en $20 \mu \mathrm{L}$ de buffer de lisis.

\section{Ensayo TUNEL}

El ensayo TUNEL (del inglés: TdT-mediated dUTP Nick-End Labeling) es utilizado para determinar la fragmentación del ADN de células apoptóticas mediante la incorporación de fluoresceína-12-dUTP al extremo 3'-OH de la cadena del ADN. Después del crecimiento y tratamiento de las células sobre cubreobjetos de vidrio estériles, retiramos el medio de cultivo y fijamos las células con paraformaldehído al $4 \%$ durante 15 minutos. A continuación, las células se lavaron con PBS $1 \mathrm{X}$ frío y añadimos Tritón X-100 al $0.2 \%$ durante 5 minutos para permeabilizar. Se bloquearon las células con el buffer ( $200 \mathrm{mM}$ cacodilato de potasio, $25 \mathrm{mM}$ Tris- $\mathrm{HCl}, 0,2 \mathrm{mM}$ DTT, $0,25 \mathrm{mg} / \mathrm{mL}$ BSA, $2,5 \mathrm{mM}$ clorhidrato de cobalto) a temperatura ambiente. Posteriormente, se añadieron $5 \mu \mathrm{L}$ por punto de $50 \mu \mathrm{M}$ fluoresceína-12-dUTP, 100 $\mu \mathrm{M}$ dATP, $10 \mathrm{mM}$ Tris-HCl ( $\mathrm{pH}$ 7.6), $1 \mathrm{mM}$ EDTA para $\mathrm{rTdT}$. Las células se incubaron en una atmósfera húmeda en la oscuridad durante 1 hora a $37^{\circ} \mathrm{C}$. Para finalizar la reacción, añadimos $1 \mathrm{~mL}$ de SSC 20X durante 15 minutos. Se llevaron a cabo las indicaciones del protocolo de DeadEnd ${ }^{T M}$ Fluorometric TUNEL System de PROMEGA. Por último, las células se lavaron 3 veces con PBS 1X. Observamos y evaluamos la emisión de fluorescencia verde (fluoresceína-12-dUTP) de las células apoptóticas mediante el uso del microscopio confocal Zeiss.

\section{Reactivos y estimulaciones}

En algunos experimentos las células de cultivo fueron tratadas con inhibidores del proteasoma como el MG-132 de Calbiochem (Inhibidor potente y reversible) y la lactacistina (inhibidor irreversible) de SIGMA-ALDRICH a una concentración de 20-35 $\mu \mathrm{M}$ o $5 \mu \mathrm{M}$ respectivamente, durante diferentes tiempos indicados en cada experimento. También, se empleó la cicloheximida (SIGMA-ALDRICH) a una concentración de $50 \mu \mathrm{g} / \mathrm{mL}$ para realizar ensayos de estabilidad proteica.

El daño en el ADN fue producido por diferentes dosis (3Gy-10Gy) de radiación ionizante usando el irradiador Gammacell 1000 Elite con fuente de ${ }^{137} \mathrm{Cs}$ que emite radiación gamma de $\mathrm{E}=662 \mathrm{KeV}$, o mediante radiación ultravioleta con el equipo 
Stratalinker (Stratagene). Además, se utilizaron agentes radiomiméticos como la doxorrubicina (SIGMA-ALDRICH) a $3 \mu \mathrm{M}$ o $1 \mu \mathrm{M}$ durante 1 o 2 horas, respectivamente. En este trabajo también se utilizó la cafeína (SIGMA-ALDRICH) en una concentración de $10 \mathrm{mM}$ durante 1 hora, este estimulante del sistema nervioso central, también es usado como inhibidor del mecanismo de reparación del ADN no selectivo. Por otro lado, se empleó el compuesto K55933 (TOCRIS bioscience) un inhibidor potente, selectivo y competitivo de la quinasa ATM a $10 \mu \mathrm{M}$ durante 1 hora. Las células fueron tratadas con estos inhibidores 1 hora antes de producir daño en el ADN con radiación ionizante o drogas quimioterapéuticas.

Para los ensayos de apoptosis se utilizó el fármaco citotóxico camptotecina a $5 \mu \mathrm{M}$ a diferentes tiempo según las condiciones de cada experimento. 


\begin{tabular}{|c|c|c|}
\hline \multicolumn{3}{|c|}{ OLIGONUCLEÓTIDOS } \\
\hline Denominación & Secuencia $5^{\prime}-3^{\prime}$ & Uso \\
\hline VRK2TA & AGTGAGAGAAGCGCTGAGTCCT & $\begin{array}{c}\text { Amplificación VRK2 } \\
\text { humana RT-PCR }\end{array}$ \\
\hline VRK2TB & CAAAGGTTCTTGAGACTCTTG & $\begin{array}{c}\text { Amplificación VRK2 } \\
\text { humana RT-PCR }\end{array}$ \\
\hline GAPDH5' & GGTCTTACTCCTTGGAGGCCATGTG & $\begin{array}{l}\text { Amplificación GAPDH } \\
\text { humana RT-PCR }\end{array}$ \\
\hline GAPDH3' & ACCTAACTACATGGTTTACATGTT & $\begin{array}{l}\text { Amplificación GAPDH } \\
\text { humana RT-PCR }\end{array}$ \\
\hline $\begin{array}{l}\text { Bax Oligo A } \\
\text { forward }\end{array}$ & GGCCCACCAGCTCTGAGCAGA & $\begin{array}{c}\text { Amplificación Bax RT- } \\
\text { PCR }\end{array}$ \\
\hline $\begin{array}{l}\text { Bax Oligo B } \\
\text { reverse }\end{array}$ & GCCACGTGGGCGTCCCAAAGT & $\begin{array}{c}\text { Amplificación Bax RT- } \\
\text { PCR }\end{array}$ \\
\hline $\begin{array}{l}\text { Bcl-xL Oligo A } \\
\text { forward }\end{array}$ & TCCTTGTCTACGCTTTCCACG & $\begin{array}{c}\text { Amplificación Bcl-xL } \\
\text { RT-PCR }\end{array}$ \\
\hline $\begin{array}{l}\mathrm{Bcl}-\mathrm{xL} \text { Oligo } \mathrm{B} \\
\text { reverse }\end{array}$ & GGTCGCATTGTGGCCTTT & $\begin{array}{c}\text { Amplificación Bcl-xL } \\
\text { RT-PCR }\end{array}$ \\
\hline $\begin{array}{l}\mathrm{Bcl}-2 \text { Oligo } \mathrm{A} \\
\text { forward }\end{array}$ & CATGTGTGTGGAGAGCGTCAA & $\begin{array}{c}\text { Amplificación Bcl-2 } \\
\text { RT-PCR }\end{array}$ \\
\hline $\begin{array}{l}\text { Bcl-2 Oligo B } \\
\text { reverse }\end{array}$ & GCCGGTTCAGGTACTCAGTCA & $\begin{array}{c}\text { Amplificación Bcl-2 } \\
\text { RT-PCR }\end{array}$ \\
\hline $\begin{array}{l}\text { NBS1 total (A) } \\
\text { forward }\end{array}$ & GAAATTGAGTTCCGCAGTTGTC & $\begin{array}{c}\text { Amplificación NBS1 } \\
\text { RT-PCR }\end{array}$ \\
\hline $\begin{array}{l}\text { NBS1 total }(\mathrm{B}) \\
\text { reverse }\end{array}$ & GGATTCTCATCTTAGCCAAAG & $\begin{array}{c}\text { Amplificación NBS1 } \\
\text { RT-PCR }\end{array}$ \\
\hline $\begin{array}{l}\text { NBS1 S343A } \\
\text { forward }\end{array}$ & AGGACCAAGCCTTGCACAAGGCGTGTCAGTTGATG & $\begin{array}{l}\text { Mutagénesis de NBS1 } \\
\text { Serina } 343 \text { a Alanina }\end{array}$ \\
\hline $\begin{array}{l}\text { NBS1 S343A } \\
\text { reverse }\end{array}$ & CATCAACTGACACGCCTTGTGCAAGGCTTGGTCCT & $\begin{array}{l}\text { Mutagénesis de NBS1 } \\
\text { Serina } 343 \text { a Alanina }\end{array}$ \\
\hline $\begin{array}{l}\text { NBS1 S432A } \\
\text { forward }\end{array}$ & CAAACTATCAGCTTGCACCAACTAAATTGCCAAGT & $\begin{array}{l}\text { Mutagénesis de NBS1 } \\
\text { Serina } 432 \text { a Alanina }\end{array}$ \\
\hline $\begin{array}{l}\text { NBS1 S432A } \\
\text { reverse }\end{array}$ & ACTTGGCAATTTAGTTGGTGCAAGCTGATAGTTTG & $\begin{array}{l}\text { Mutagénesis de NBS1 } \\
\text { Serina } 432 \text { a Alanina }\end{array}$ \\
\hline $\begin{array}{l}\text { Pex2hVRK1 } \\
\text { forward }\end{array}$ & CCAACGAGCTGCAAAACC & $\begin{array}{c}\text { Amplificación VRK1 } \\
\text { humana RT-PCR }\end{array}$ \\
\hline
\end{tabular}




\begin{tabular}{|c|c|c|}
\hline $\begin{array}{l}\text { Pex } 2 \text { hVRK1 } \\
\text { reverse }\end{array}$ & TGTCATGTAGACCAGACCCCC & $\begin{array}{c}\text { Amplificación VRK1 } \\
\text { humana RT-PCR }\end{array}$ \\
\hline $\begin{array}{l}\text { DOLRA siVRK1-01 } \\
\text { (Thermo) } \\
\text { forward }\end{array}$ & GAAAGAGAGUCCAGAAGUAUUUU & $\begin{array}{l}\text { ARN de interferencia } \\
\text { para VRK1 humana } \\
\text { (rescate de fenotipo) }\end{array}$ \\
\hline $\begin{array}{l}\text { DOLRA siVRK1-01 } \\
\text { (Thermo) } \\
\text { reverse }\end{array}$ & AAUACUUCUGGACUCUCUUUCUU & $\begin{array}{l}\text { ARN de interferencia } \\
\text { para VRK1 humana } \\
\text { (rescate de fenotipo) }\end{array}$ \\
\hline siVRK1-02 & CAAGGAACCUGGUGUUGAAUU & $\begin{array}{c}\text { ARN de interferencia } \\
\text { para VRK1 humana }\end{array}$ \\
\hline siVRK1-03 & GGAAUGGAAAGUAGGAUUA & $\begin{array}{c}\text { ARN de interferencia } \\
\text { para VRK1 humana }\end{array}$ \\
\hline siVRK2-06 & GCAAGGUUCUGGAUGAUAU & $\begin{array}{l}\text { ARN de interferencia } \\
\text { para VRK2 humana }\end{array}$ \\
\hline siVRK2-08 & CACAAUAGGUUAAUCGAAA & $\begin{array}{c}\text { ARN de interferencia } \\
\text { para VRK2 humana }\end{array}$ \\
\hline SiVRK2-M & GATATTGTCCCAATGGGAA & $\begin{array}{l}\text { ARN de interferencia } \\
\text { para VRK2 humana }\end{array}$ \\
\hline
\end{tabular}

Tabla 3. Información general de los oligonucleótidos utilizados. Secuencias de los oligonucleótidos y su uso en este trabajo. 


\begin{tabular}{|c|c|c|c|c|c|}
\hline \multicolumn{6}{|c|}{ ANTICUERPOS } \\
\hline Anticuerpo & Antígeno & Tipo & $\begin{array}{c}\text { Dilución de } \\
\text { uso }\end{array}$ & $\begin{array}{l}\text { MW: } \\
\text { kDa }\end{array}$ & Procedencia \\
\hline Anti-VRK1 1F6 & $\begin{array}{l}\text { VRK1 humana (aa } \\
\text { 333-396) }\end{array}$ & $\begin{array}{c}\text { Monoclonal } \\
\text { ratón }\end{array}$ & WB 1:1000 & 45 & $\begin{array}{l}\text { Producción } \\
\text { propia }\end{array}$ \\
\hline Anti-VRK1 1b5 & VRK1 humana & $\begin{array}{l}\text { Monoclonal } \\
\text { ratón }\end{array}$ & WB 1:1000 & 45 & $\begin{array}{l}\text { Producción } \\
\text { propia }\end{array}$ \\
\hline Anti-VRK1 VC & $\begin{array}{c}\text { VRK1 humana (aa } \\
267-396)\end{array}$ & $\begin{array}{l}\text { Policlonal } \\
\text { conejo }\end{array}$ & WB 1:1000 & 45 & $\begin{array}{l}\text { Producción } \\
\text { propia }\end{array}$ \\
\hline Anti-VRK1 & $\begin{array}{l}\text { VRK1 humana (aa } \\
5-142 \text { ) }\end{array}$ & $\begin{array}{l}\text { Policlonal } \\
\text { conejo }\end{array}$ & WB 1:1000 & 45 & $\begin{array}{l}\text { SIGMA- } \\
\text { ALDRICH }\end{array}$ \\
\hline Anti-VRK2 & VRK2 humana & $\begin{array}{l}\text { Policlonal } \\
\text { conejo }\end{array}$ & WB 1:1000 & 58 & $\begin{array}{l}\text { Producción } \\
\text { propia }\end{array}$ \\
\hline Akt1/2/3 & $\begin{array}{c}\text { AKT1/2/3 (aa 345- } \\
480)\end{array}$ & $\begin{array}{l}\text { Policlonal } \\
\text { conejo }\end{array}$ & WB 1:1000 & 60 & Santa cruz \\
\hline p-AKT (D9E) & p-Ser 473 AKT & $\begin{array}{l}\text { Policlonal } \\
\text { conejo }\end{array}$ & WB 1:1000 & 60 & Cell Signaling \\
\hline p-ATM & pSer 1981 ATM & $\begin{array}{l}\text { Monoclonal } \\
\text { ratón }\end{array}$ & WB 1:500 & 350 & Calbiochem \\
\hline ATM & ATM (aa 819-844) & $\begin{array}{l}\text { Policlonal } \\
\text { conejo }\end{array}$ & WB 1:1000 & 350 & Calbiochem \\
\hline $\mathrm{Bcl}-2$ (N-19) & $\begin{array}{l}\mathrm{Bcl}-2 \text { (extremo } \mathrm{N}- \\
\text { terminal) }\end{array}$ & $\begin{array}{l}\text { Policlonal } \\
\text { conejo }\end{array}$ & WB 1:1000 & 26 & Santa Cruz \\
\hline$\beta$-Actina & $\begin{array}{c}\beta \text {-Actina (extremo } \\
\mathrm{N} \text {-terminal) }\end{array}$ & $\begin{array}{l}\text { Monoclonal } \\
\text { ratón }\end{array}$ & WB 1:5000 & 42 & $\begin{array}{l}\text { SIGMA- } \\
\text { ALDRICH }\end{array}$ \\
\hline Bax 2D2 & Bax (aa 3-16) & $\begin{array}{l}\text { Monoclonal } \\
\text { ratón }\end{array}$ & WB 1:1000 & 23 & Enzo \\
\hline Bax $6 \mathrm{~A} 7$ & Bax (aa 12-24) & $\begin{array}{l}\text { Monoclonal } \\
\text { ratón }\end{array}$ & WB 1:1000 & 23 & BD Biosciences \\
\hline $\mathrm{Bcl}-\mathrm{X}$ & $\begin{array}{c}\mathrm{Bcl}-\mathrm{xL} / \mathrm{Bcl}-\mathrm{xS} \text { (aa } \\
3-14)\end{array}$ & $\begin{array}{l}\text { Monoclonal } \\
\text { ratón }\end{array}$ & WB 1:1000 & $25-29$ & BD Biosciences \\
\hline 53BP1 (H300) & 53BP1 (aa 1-300) & $\begin{array}{l}\text { Policlonal } \\
\text { conejo }\end{array}$ & IF: $1: 200$ & 350 & Santa Cruz \\
\hline Chk2 (1C12) & Chk2 & $\begin{array}{l}\text { Monoclonal } \\
\text { ratón }\end{array}$ & WB 1:1000 & 62 & Cell Signaling \\
\hline $\mathrm{p}-\mathrm{Chk} 2$ & p-Thr 68 Chk2 & $\begin{array}{l}\text { Policlonal } \\
\text { conejo }\end{array}$ & WB 1:1000 & 62 & Cell Signaling \\
\hline Citocromo c & $\begin{array}{c}\text { Citocromo C (aa } \\
\text { 93-104) }\end{array}$ & $\begin{array}{l}\text { Monoclonal } \\
\text { ratón }\end{array}$ & WB 1:1000 & 15 & BD Biosciences \\
\hline ERK2 (C-14) & $\begin{array}{c}\text { ERK2 (extremo C- } \\
\text { terminal) }\end{array}$ & $\begin{array}{l}\text { Policlonal } \\
\text { Conejo }\end{array}$ & WB 1:10000 & $42-44$ & Santa Cruz \\
\hline$p-E R K(E-4)$ & p-Tyr 204 ERK & $\begin{array}{l}\text { Monoclonal } \\
\text { ratón }\end{array}$ & WB 1:5000 & 44 & Santa Cruz \\
\hline Anti-Flag & Epítopo Flag & $\begin{array}{l}\text { Policlonal } \\
\text { Conejo }\end{array}$ & WB 1:1000 & - & $\begin{array}{l}\text { SIGMA- } \\
\text { ALDRICH }\end{array}$ \\
\hline Anti-Flag M5 & Epítopo Flag & $\begin{array}{l}\text { Monoclonal } \\
\text { ratón }\end{array}$ & WB 1:1000 & - & $\begin{array}{l}\text { SIGMA- } \\
\text { ALDRICH }\end{array}$ \\
\hline Anti-GST (B-14) & Epítopo GST & $\begin{array}{l}\text { Monoclonal } \\
\text { ratón }\end{array}$ & WB 1:1000 & - & Santa Cruz \\
\hline Anti-HA (F-7) & Epítopo HA & $\begin{array}{l}\text { Monoclonal } \\
\text { ratón }\end{array}$ & WB 1:1000 & - & Santa Cruz \\
\hline Anti-HA & Epítopo HA & $\begin{array}{l}\text { Policlonal } \\
\text { conejo }\end{array}$ & WB 1:1000 & - & $\begin{array}{l}\text { SIGMA- } \\
\text { ALDRICH }\end{array}$ \\
\hline H2A.X & H2A.X & $\begin{array}{l}\text { Policlonal } \\
\text { conejo }\end{array}$ & $\begin{array}{l}\text { WB } 1: 500 \\
\text { IF: } 1: 100\end{array}$ & 15 & Cell Signaling \\
\hline p-H2A.X & pSer 139 H2A.X & $\begin{array}{l}\text { Monoclonal } \\
\text { ratón }\end{array}$ & $\mid F: 1: 100$ & 17 & Millipore \\
\hline
\end{tabular}




\begin{tabular}{|c|c|c|c|c|c|}
\hline MDC1 & MDC1 & $\begin{array}{l}\text { Policlonal } \\
\text { conejo }\end{array}$ & $\begin{array}{l}\text { WB } 1: 1000 \\
\text { IF:1:100 }\end{array}$ & 250 & Abcam \\
\hline MDC1-50 & MDC1 & $\begin{array}{c}\text { Monoclonal } \\
\text { ratón }\end{array}$ & $\begin{array}{l}\text { WB: } 1: 500 \\
\text { IF:1:50 }\end{array}$ & 250 & $\begin{array}{l}\text { SIGMA- } \\
\text { ALDRICH }\end{array}$ \\
\hline Anti-Myc & Epítopo Myc & $\begin{array}{l}\text { Policlonal } \\
\text { conejo }\end{array}$ & WB 1:1000 & - & Millipore \\
\hline Anti-Myc & Epítopo Myc & $\begin{array}{l}\text { Monoclonal } \\
\text { ratón }\end{array}$ & WB 1:1000 & - & Millipore \\
\hline Anti-AU5 & Epítopo AU5 & $\begin{array}{l}\text { Monoclonal } \\
\text { ratón }\end{array}$ & WB: 1:1000 & - & Covance \\
\hline Anti-AU5 & Epítopo AU5 & $\begin{array}{l}\text { Policlonal } \\
\text { conejo }\end{array}$ & WB: 1:1000 & - & Covance \\
\hline NBS1 (Nibrin) & $\begin{array}{c}\text { NBS1 (aa 692- } \\
706 \text { ) }\end{array}$ & $\begin{array}{l}\text { Policlonal } \\
\text { conejo }\end{array}$ & WB 1:1000 & 95 & $\begin{array}{l}\text { SIGMA- } \\
\text { ALDRICH }\end{array}$ \\
\hline NBS1 & $\begin{array}{c}\text { NBS1 (aa 620- } \\
732 \text { ) }\end{array}$ & $\begin{array}{l}\text { Monoclonal } \\
\text { ratón }\end{array}$ & IF:1:200 & 95 & BD Biosciences \\
\hline p-NBS1 Ser343 & pSer 343 NBS1 & $\begin{array}{l}\text { Policlonal } \\
\text { conejo }\end{array}$ & WB 1:500 & 95 & Cell Signaling \\
\hline p-NBS1 Ser432 & pSer 432 NBS1 & $\begin{array}{l}\text { Monoclonal } \\
\text { conejo }\end{array}$ & WB 1:500 & 95 & $\begin{array}{c}\text { LifeSpan } \\
\text { Biosciences }\end{array}$ \\
\hline PARP & $\begin{array}{c}\text { Poly (ADP-Ribose) } \\
\text { Polymerase }\end{array}$ & $\begin{array}{c}\text { Monoclonal } \\
\text { ratón }\end{array}$ & WB 1:1000 & $\begin{array}{c}113 \\
\text { Entera, } \\
89 \\
\text { Clivada }\end{array}$ & BD Biosciences \\
\hline
\end{tabular}

Tabla 4. Anticuerpos. Se detallan los anticuerpos primarios empleados, así como la dilución utilizada para ensayos de Western blot (WB) e inmunofluorescencia (IF) y su procedencia. Los anticuerpos fosfo-específicos utilizados se indican con una p previa al nombre del anticuerpo. 


\begin{tabular}{|c|c|c|c|c|}
\hline \multicolumn{5}{|c|}{ LÍNEAS CELULARES } \\
\hline Línea celular & Organismo & Procedencia & Características & $\begin{array}{l}\text { Medio de } \\
\text { Cultivo }\end{array}$ \\
\hline HEK-293T & Humano & Embrionarias de riñón & & $\begin{array}{c}\text { DMEM, } 10 \% \\
\text { FBS }\end{array}$ \\
\hline A549 & Humano & Carcinoma de Pulmón & & $\begin{array}{l}\text { RPMI, } 10 \% \\
\text { FBS }\end{array}$ \\
\hline H1299 & Humano & $\begin{array}{l}\text { Carcinoma de pulmón } \\
\text { de célula no pequeña }\end{array}$ & Deficientes p53 & $\begin{array}{l}\text { RPMI, } 10 \% \\
\text { FBS }\end{array}$ \\
\hline HT-144 & Humano & Melanoma & $\begin{array}{l}\text { Deficientes de } \\
\text { ATM }\end{array}$ & $\begin{array}{c}\text { DMEM, } 10 \% \\
\text { FBS }\end{array}$ \\
\hline GM9607 & Humano & $\begin{array}{c}\text { Fibroblastos } \\
\text { transformados SV40 }\end{array}$ & $\begin{array}{c}\text { Deficientes de } \\
\text { ATM }\end{array}$ & $\begin{array}{c}\text { DMEM, } 10 \% \\
\text { FBS }\end{array}$ \\
\hline HeLa & Humano & $\begin{array}{l}\text { Adenocarcinoma de } \\
\text { cérvix }\end{array}$ & $\begin{array}{c}\text { Transformadas } \\
\text { por VPH-18 }\end{array}$ & $\begin{array}{c}\text { DMEM, } 10 \% \\
\text { FBS }\end{array}$ \\
\hline MDA-MB-231 & Humano & Carcinoma de mama & Subtipo basal B & $\begin{array}{c}\text { DMEM, } 10 \% \\
\text { FBS }\end{array}$ \\
\hline MCF7 & Humano & $\begin{array}{l}\text { Adenocarcinoma de } \\
\text { mama }\end{array}$ & & $\begin{array}{c}\text { DMEM, } 10 \% \\
\text { FBS }\end{array}$ \\
\hline U2OS & Humano & Osteosarcoma & & $\begin{array}{c}\text { DMEM, } 10 \% \\
\text { FBS }\end{array}$ \\
\hline НCT-116 & Humano & Carcinoma colorectal & & $\begin{array}{l}\text { McCoy's, } \\
10 \% \text { FBS }\end{array}$ \\
\hline
\end{tabular}

Tabla 5. Información general de las líneas celulares. Todas las líneas celulares utilizadas crecieron en su correspondiente medio de cultivo en condiciones normales a $37^{\circ} \mathrm{C}, 5 \%$ de $\mathrm{CO}_{2}$ y $98 \%$ de humedad relativa. 


\begin{tabular}{|c|c|c|c|}
\hline \multicolumn{4}{|c|}{ PLÁSMIDOS DE ADN RECOMBINANTE } \\
\hline Construcción & Vector & Inserto & Uso \\
\hline HA-VRK1 & pCEFL-HA & VRK1 & $\begin{array}{c}\text { Expresión en } \\
\text { eucariotas, epítopo } \\
\text { en extremo amino }\end{array}$ \\
\hline $\mathrm{HA}-\mathrm{VRK} 1^{\mathrm{K} 179 \mathrm{E}}$ & pCEFL-HA & $\begin{array}{c}\text { VRK1 }{ }^{\text {K179E }} \\
\text { quinasa inactiva }\end{array}$ & $\begin{array}{c}\text { Expresión en } \\
\text { eucariotas, epítopo } \\
\text { en extremo amino }\end{array}$ \\
\hline HA-VRK1 RX & pCEFL-HA & $\begin{array}{l}\text { VRK1 mutación } \\
\text { R358X }\end{array}$ & $\begin{array}{c}\text { Expresión en } \\
\text { eucariotas, epítopo } \\
\text { en extremo amino }\end{array}$ \\
\hline HA-VRK2A & pCEFL-HA & VRK2A & $\begin{array}{c}\text { Expresión en } \\
\text { eucariotas, epítopo } \\
\text { en extremo amino }\end{array}$ \\
\hline HA-VRK2B & pCEFL-HA & VRK2B & $\begin{array}{c}\text { Expresión en } \\
\text { eucariotas, epítopo } \\
\text { en extremo amino }\end{array}$ \\
\hline GST-VRK1 & pCEFL-GST & VRK1 & $\begin{array}{c}\text { Expresión en } \\
\text { eucariotas, epítopo } \\
\text { en extremo amino }\end{array}$ \\
\hline GST-VRK1-C & pCEFL-GST & $\begin{array}{c}\text { VRK1-Carboxi (aa } \\
\text { 267-396) }\end{array}$ & $\begin{array}{c}\text { Expresión en } \\
\text { eucariotas, epítopo } \\
\text { en extremo amino }\end{array}$ \\
\hline GST-VRK2A & pCEFL-GST & VRK2A & $\begin{array}{c}\text { Expresión en } \\
\text { eucariotas, epítopo } \\
\text { en extremo amino }\end{array}$ \\
\hline GST-VRK2B & pCEFL-GST & VRK2B & $\begin{array}{c}\text { Expresión en } \\
\text { eucariotas, epítopo } \\
\text { en extremo amino }\end{array}$ \\
\hline VRK1-Myc & pcDNA3.1 & VRK1 & $\begin{array}{c}\text { Expresión en } \\
\text { eucariotas, epítopo } \\
\text { en extremo } \\
\text { carboxilo }\end{array}$ \\
\hline VRK1-NL-Myc & pcDNA3.1 & $\begin{array}{l}\text { VRK1-NL (amino } \\
\text { largo aa 1-332) }\end{array}$ & $\begin{array}{c}\text { Expresión en } \\
\text { eucariotas, epítopo } \\
\text { en extremo } \\
\text { carboxilo }\end{array}$ \\
\hline VRK1-NC-Myc & pcDNA3.1 & $\begin{array}{l}\text { VRK1-NC (amino } \\
\text { corto aa } 1-267 \text { ) }\end{array}$ & $\begin{array}{c}\text { Expresión en } \\
\text { eucariotas, epítopo } \\
\text { en extremo } \\
\text { carboxilo }\end{array}$ \\
\hline pGEX-GST-VRK1 & pGEX4T1-GST & VRK1 & $\begin{array}{l}\text { Expresión como } \\
\text { proteína de fusión } \\
\text { con GST en } E \text {. Coli }\end{array}$ \\
\hline pGEX-GST-VRK1 $1^{\text {K179E }}$ & pGEX4T1-GST & $\begin{array}{c}\text { VRK1 }{ }^{\mathrm{K} 179 \mathrm{E}} \text { quinasa } \\
\text { inactiva }\end{array}$ & $\begin{array}{l}\text { Expresión como } \\
\text { proteína de fusión } \\
\text { con GST en E. Coli }\end{array}$ \\
\hline pGEX-p53 (1-85) & pGEX-2T & p53 murino (aa 1-85) & $\begin{array}{l}\text { Expresión como } \\
\text { proteína de fusión } \\
\text { con GST en E. Coli }\end{array}$ \\
\hline
\end{tabular}




\begin{tabular}{|c|c|c|c|}
\hline HA-MDC1 & pCDNA3 & MDC1 WT & $\begin{array}{c}\text { Expresión en } \\
\text { eucariotas con } \\
\text { epítopo HA }\end{array}$ \\
\hline FLAG-NBS1 & pIRES2 & NBS1 WT & $\begin{array}{c}\text { Expresión en } \\
\text { eucariotas con } \\
\text { epítopo FLAG }\end{array}$ \\
\hline FLAG-NBS1 & pCMV-Tag4b & NBS1 WT & $\begin{array}{c}\text { Expresión en } \\
\text { eucariotas con } \\
\text { epítopo FLAG }\end{array}$ \\
\hline FLAG-NBS1 S343A & pCMV-Tag4b & $\begin{array}{c}\text { NBS1 mutación } \\
\text { S343A }\end{array}$ & $\begin{array}{c}\text { Expresión en } \\
\text { eucariotas con } \\
\text { epítopo FLAG }\end{array}$ \\
\hline FLAG-NBS1 S432A & pCMV-Tag4b & $\begin{array}{c}\text { NBS1 mutación } \\
\text { S432A }\end{array}$ & $\begin{array}{c}\text { Expresión en } \\
\text { eucariotas con } \\
\text { epítopo FLAG }\end{array}$ \\
\hline HA-ATM & pBJ-1-HA & ATM WT & $\begin{array}{c}\text { Expresión en } \\
\text { eucariotas con } \\
\text { epítopo HA }\end{array}$ \\
\hline HA-Ub & pSSK-HA & Ubiquitina & $\begin{array}{c}\text { Expresión en } \\
\text { eucariotas con } \\
\text { epítopo HA }\end{array}$ \\
\hline HA-RNF8 & pcDNA3.1 & RNF8 & $\begin{array}{c}\text { Expresión en } \\
\text { eucariotas con } \\
\text { epítopo HA }\end{array}$ \\
\hline Mdm2 & $\mathrm{pCoC}$ & Mdm2 & $\begin{array}{c}\text { Expresión en } \\
\text { eucariotas sin } \\
\text { epítopo }\end{array}$ \\
\hline FLAG-PUMA & pCMV-FLAG & PUMA alpha & $\begin{array}{c}\text { Expresión en } \\
\text { eucariotas con } \\
\text { epítopo FLAG }\end{array}$ \\
\hline AU1-Bad & pcDNA3 & Bad & $\begin{array}{c}\text { Expresión en } \\
\text { eucariotas con } \\
\text { epítopo AU1 }\end{array}$ \\
\hline HA-Bnip3L & PCR-3.1 & Bnip3L & $\begin{array}{c}\text { Expresión en } \\
\text { eucariotas con } \\
\text { epítopo HA }\end{array}$ \\
\hline $\mathrm{HA}-\mathrm{Bcl}-\mathrm{xL}$ & pcDNA3.1 & $\mathrm{Bcl}-\mathrm{xL}$ & $\begin{array}{c}\text { Expresión en } \\
\text { eucariotas con } \\
\text { epítopo HA }\end{array}$ \\
\hline AU1-Bax & p8-AU1 & Bax & $\begin{array}{c}\text { Expresión en } \\
\text { eucariotas con } \\
\text { epítopo AU1 }\end{array}$ \\
\hline Bax-Luc & pGL3-Luc & $\begin{array}{c}\text { Promotor Bax }(-687 \\
\text { a }-318)\end{array}$ & $\begin{array}{l}\text { Expresión en } \\
\text { eucariotas }\end{array}$ \\
\hline
\end{tabular}

Tabla 6. Información general de los vectores recombinantes. Se indican los vectores y su correspondiente inserto utilizados en este trabajo. 
RESULTADOS 



\section{IMPLICACIÓN DE LA QUINASA HUMANA VRK1 EN LA RESPUESTA AL DAÑO GÉNICO}

\subsection{VRK1 en la respuesta al daño en el ADN}

\subsubsection{Localización subcelular de VRK1}

La localización subcelular de la quinasa humana VRK1 se ha estudiado tanto en líneas celulares como en tejidos. Aunque esta quinasa tiene una localización principalmente nuclear, en algunas líneas celulares se ha identificado una subpoblación en el citoplasma mediante el uso de un anticuerpo específico. Por ejemplo, con el anticuerpo monoclonal anti-VRK1 1F6 se reconoce una subpoblación en el aparato de Golgi, debido a una posible unión a un epítopo diferente en esta proteína (Valbuena et al, 2007) (Lopez-Sanchez et al, 2009). La localización de VRK1 es importante para el desempeño de sus actividades mediadas por interacciones y fosforilaciones, así que muy probablemente su localización debe estar regulada por mecanismos concretos que aún no conocemos. En la figura 25, podemos observar en la inmunofluorescencia la localización subcelular de VRK1 en diferentes líneas celulares, la subpoblación de VRK1 en el citoplasma se detectó con el anticuerpo monoclonal 1F6, mientras la subpoblación nuclear se detectó con el anticuerpo monoclonal 1b5. Ambos anticuerpos reconocen la región carboxilo terminal de VRK1.

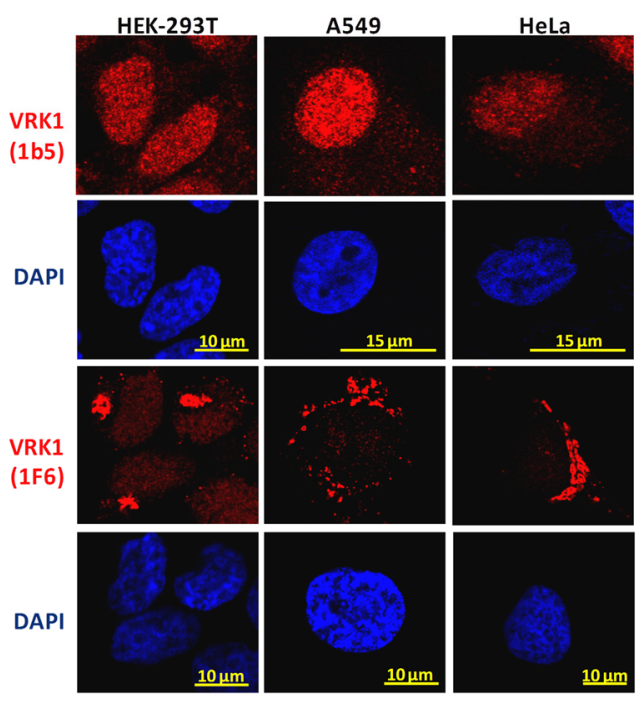

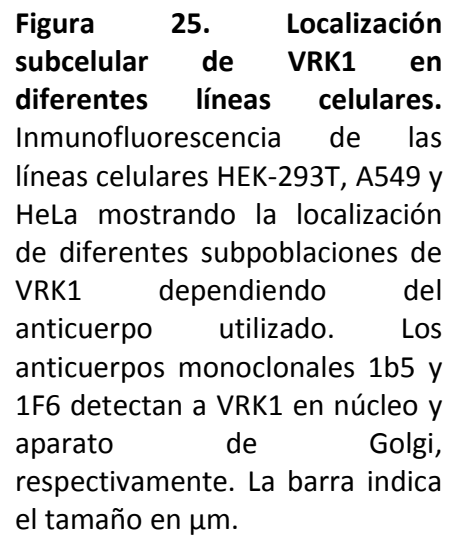




\subsubsection{El daño en el ADN incrementa la actividad de VRK1}

La respuesta al daño en el $A D N$ es un mecanismo esencial para mantener la integridad del $A D N$, asegurando la supervivencia celular y evitando la transmisión de mutaciones nocivas que conlleven al desarrollo de diferentes enfermedades como el cáncer. Mediante estudios llevados a cabo en el laboratorio, se conoce que la quinasa humana VRK1 aumenta su actividad tras estímulos que producen daño en el ADN, como la luz ultravioleta, la radiación ionizante o algunos fármacos como la doxorubicina o el etopósido (Valbuena et al, 2011). Para revisar el incremento de la actividad de VRK1 después del daño al ADN, se realizó un ensayo quinasa utilizando VRK1 endógena inmunoprecipitada de células de carcinoma de pulmón (A549) tratadas con radiación ionizante (rayos gamma de la fuente de Cesio ${ }^{137}$ ) que produce roturas de doble cadena en el ADN. Estas células crecieron en condiciones normales con medio de cultivo suplementado con $10 \%$ de FBS. Como se mencionaba anteriormente en la introducción, VRK1 es regulada transcripcionalmente por factores de crecimiento presentes en el suero. Así mismo se ha observado que la retirada prolongada del suero produce una disminución en la actividad de VRK1. Por este motivo, después de que las células A549 alcanzaran una confluencia de entre el $80 \%$ y $90 \%$, fueron crecidas con $0.2 \%$ de FBS con el fin de reducir la actividad de la quinasa VRK1 y evidenciar la activación producida por la irradiación. Transcurridas 15 horas, las células fueron tratadas con 3 Gy de radiación ionizante y se dejaron recuperar a diferentes tiempos. Para realizar el ensayo quinasa se inmunoprecipitó VRK1 con el anticuerpo monoclonal $1 \mathrm{~F} 6$ y se utilizó la histona H3 como sustrato conocido (Figura 26).

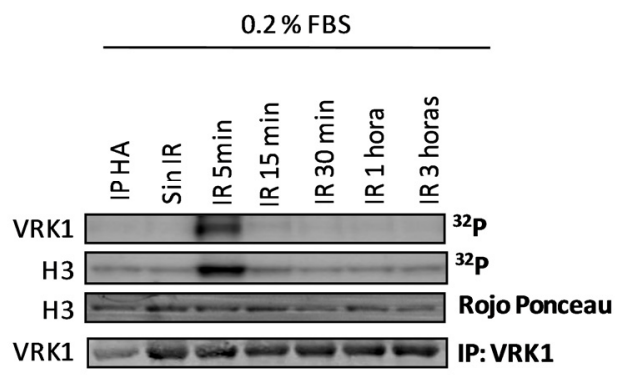

Figura 26. Rápida activación de VRK1 en respuesta a radiación ionizante. Se inmunoprecipitó VRK1 endógena de células A549 mantenidas con $0.2 \%$ FBS durante 48 horas con el anticuerpo monoclonal 1F6. Se realizó un ensayo quinasa con la VRK1 inmunoprecipitada, $\left(\gamma^{-}{ }^{32} \mathrm{P}\right)$ ATP y la histona H3 como sustrato. La incorporación de la actividad se muestra en los paneles indicados con ${ }^{32} \mathrm{P}$. Se detectaron los niveles de VRK1 precipitada con el anticuerpo policlonal anti-VRK1 (VC). La histona H3 se detectó mediante tinción con rojo Ponceau. 
Comprobamos que la actividad de VRK1, observada a través de su autofosforilación y fosforilación de su sustrato, incrementó drásticamente después de 5 minutos postirradiación en comparación con el punto control sin irradiación, disminuyendo la actividad después de 15 minutos. Estos resultados nos indican que VRK1 se activa y responde rápidamente a estímulos que producen daño en el ADN como la radiación ionizante.

Por otro lado, en ensayos de inmunofluorescencia, observamos un incremento en la intensidad de fluorescencia de VRK1 después de que las células fueran irradiadas, sin embargo, este incremento solo fue detectado mediante el uso del anticuerpo monoclonal 1b5. También se observó una redistribución de VRK1 hacia los nucléolos después de los 30 minutos post-irradiación. Transcurridas 6 horas después de la irradiación, la intensidad de fluorescencia de VRK1 disminuye hasta alcanzar los niveles basales en comparación a las células sin irradiar (Figura 27A, pie de figura en pág. 93). Para controlar la efectividad de la irradiación se marcó la proteína 53BP1 con un anticuerpo policlonal específico. El número máximo de focos de 53BP1 (promedio de 30 focos por célula) se formó entre los 15 y 30 minutos después de irradiar, disminuyendo progresivamente al transcurrir el tiempo. Las imágenes de inmunofluorescencia se tomaron en iguales condiciones de excitación del fluorocromo, de manera que los niveles de fluorescencia pudieran ser comparables entre las muestras analizadas (Figura 27B, pie de figura en pág. 93). Para comprobar si los cambios observados en los niveles de fluorescencia de VRK1 después de la irradiación correlacionaban con cambios a nivel proteico de VRK1, se realizó un Western blot en iguales condiciones a la inmunofluorescencia. Los niveles de expresión de VRK1 entre las células irradiadas y no irradiadas, utilizando el anticuerpo monoclonal 1b5, no variaron durante el tiempo tras irradiación (Figura 27C, pie de figura en pág. 93). 


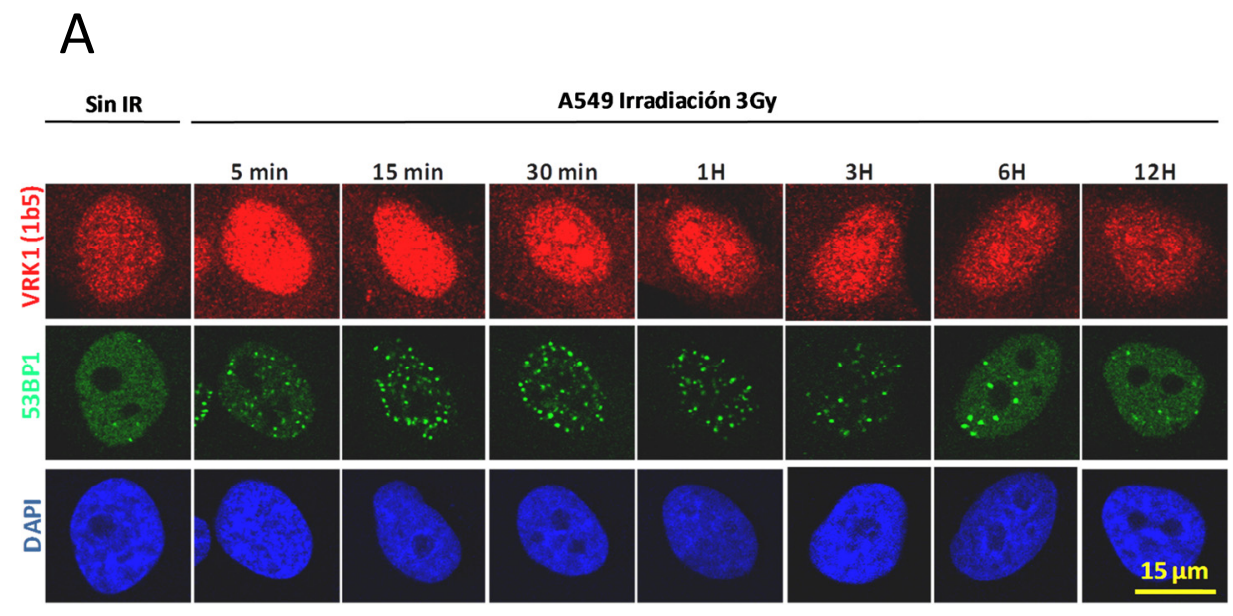

B
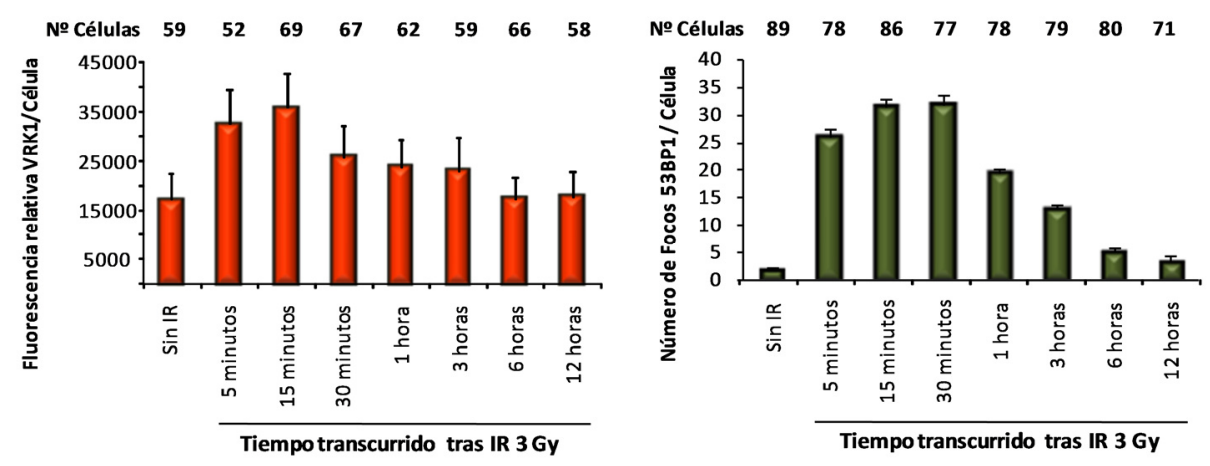

C

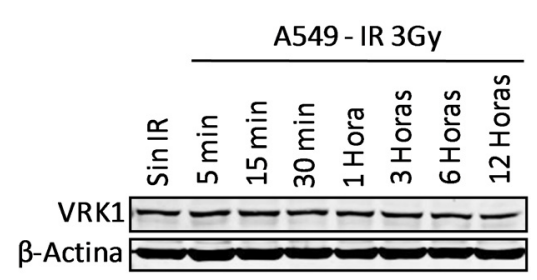


Figura 27. Respuesta de VRK1 y cinética de formación de focos de 53BP1 en respuesta a radiación ionizante. A. Células A549 fueron irradiadas con una dosis de 3 Gy o bien dejadas sin irradiar. Posteriormente, las células fueron fijadas tras diferentes tiempos de recuperación que oscilan entre 5 minutos y 12 horas. VRK1 se detectó con el anticuerpo monoclonal 1 b5 (rojo) y 53BP1 con un anticuerpo policlonal (verde). Los núcleos fueron teñidos con DAPI (azul). La barra indica $15 \mu \mathrm{m}$. B. Representación gráfica de la cuantificación de los niveles de fluorescencia y número de focos de 53BP1 por célula tras la IR. Se indica el número de células cuantificadas en la parte superior de las barras. C. Análisis por Western blot de los niveles totales de VRK1 en igualdad de condiciones al apartado A. Se detectaron los niveles de VRK1 con el anticuerpo monoclonal 1 b5 y se detectó la $\beta$-Actina como control de carga.

\subsection{Efecto de diferentes tipos de daño (radiación ionizante o fármacos quimioterapéuticos) sobre el ADN}

Como se mencionó en el apartado anterior, el daño en el ADN causado por radiación ionizante produce un incremento en los niveles de fluorescencia de VRK1 detectado específicamente por el anticuerpo monoclonal 1b5. Por tal motivo, estudiamos si en la línea celular A549 se presentaba un efecto similar al utilizar la doxorubicina, un fármaco citotóxico utilizado en quimioterapia, que se intercala en el ADN bloqueando la acción de la topoisomerasa II (la cual es necesaria para la relajación y separación del ADN para la transcripción) produciendo roturas de doble cadena en el lugar donde está actuando esta enzima (Kurz et al, 2004; Tewey et al, 1984). De igual forma, se comparó la detección de VRK1 con dos anticuerpos diferentes, el anticuerpo monoclonal 1 b5 y el anticuerpo policlonal anti-VRK1 de SIGMA-ALDRICH, los cuales reconocen la región carboxilo y amino terminal respectivamente. Se observó que los niveles de fluorescencia de VRK1 incrementaron en las células tratadas con radiación ionizante o doxorubicina. Este efecto solo se observó con el anticuerpo monoclonal 1 b5 y no con el anticuerpo policlonal anti-VRK1 de SIGMAALDRICH (Figura 28). Debido a que la radiación ionizante produce un daño más homogéneo sobre las células, el aumento de la fluorescencia de VRK1 fue más evidente que en las células tratadas con doxorubicina, ya que la acción de este fármaco depende de su capacidad de penetración y su interacción con la topoisomerasa II. 

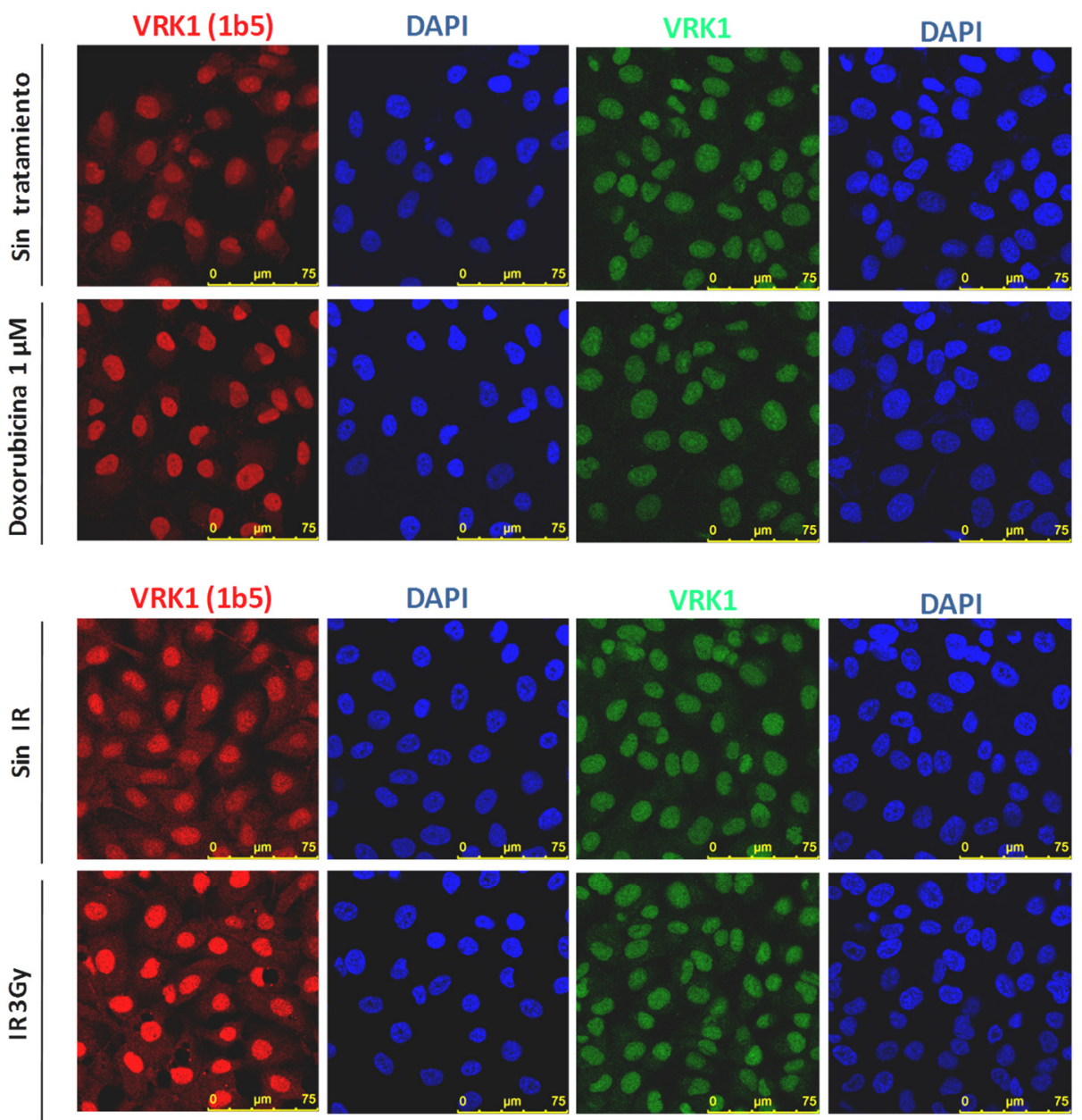

Figura 28. Comparación de la señal de fluorescencia de VRK1 en ausencia de daño y tras tratamiento con doxorubicina y radiación ionizante. Se utilizaron células A549 que fueron dejadas sin tratar, tratadas con doxorubicina $1 \mu \mathrm{m}$ o irradiadas con una dosis de $3 \mathrm{~Gy}$ de rayos gamma. Transcurrido el tiempo de recuperación ( 2 horas para el tratamiento con doxorubicina y 15 minutos tras IR) las células fueron fijadas y preparadas para inmunofluorescencia. VRK1 se detectó con los anticuerpos monoclonal 1 b5 (rojo) y policlonal anti-VRK1 de SIGMA (verde). Los núcleos se tiñeron con DAPI (azul). La barra indica $75 \mu \mathrm{m}$. 


\subsubsection{Efecto de radiación ionizante en diferentes líneas celulares (formación de focos de NBS1, MDC1 y 53BP1)}

La radiación ionizante produce roturas de doble cadena (DSBs) en el ADN. Estas DSBS son detectadas por el complejo MRN (Mre11-Rad50-NBS1). A continuación, se reclutan diferentes proteínas como ATM, MDC1, 53BP1 O BRCA, entre otras. La acumulación de estas proteínas en el lugar de la rotura forma los focos de reparación, que a través de señales coordinadas se encargan de mediar la reparación del ADN dañado. Estudiamos la formación de focos de la proteína NBS1 (miembro del complejo MRN) objeto de nuestro estudio, en diferentes líneas celulares, después de ser tratadas con radiación ionizante. Estudiamos también la formación de focos de las proteínas mediadoras MDC1 y 53BP1. Para ello se irradiaron células de osteosarcoma (U2OS), carcinoma de pulmón (A549), adenocarcinoma de cérvix (HeLa), cáncer de mama (MDA-MB-231), melanoma con deficiencia de ATM (HT144) y carcinoma colorectal (HCT116), con una dosis de 3 Gy. 30 minutos después de la recuperación, se fijaron y se realizó la inmunofluorescencia. Comprobamos que en todas las líneas celulares estudiadas, en ausencia de irradiación, las proteínas NBS1, MDC1 y 53BP1 se encontraban de forma difusa en el núcleo. Después de la estimulación con radiación ionizante, estas proteínas se relocalizaron en los sitios del ADN dañado. Sin embargo, en algunas líneas celulares como U2OS y MDA-MB-231, no se observó la formación de focos de NBS1, pero si un incremento en los niveles de fluorescencia (Figura 29A).

Por otro lado, revisamos si los niveles de expresión de NBS1 y VRK1 se afectaban tras la estimulación con radiación ionizante en diferentes líneas celulares. En la figura 27C (pág. 92) observamos que los niveles de VRK1 detectados en el Western blot con el anticuerpo monoclonal 1b5, no se afectaban al tratar las células A549 con irradiación. Sin embargo, quisimos ver si este comportamiento era similar en diferentes líneas celulares. Comprobamos en el Western blot que no había diferencias entre los niveles de NBS1, ni en los niveles de VRK1 en las líneas celulares estudiadas (Figura 29B). 


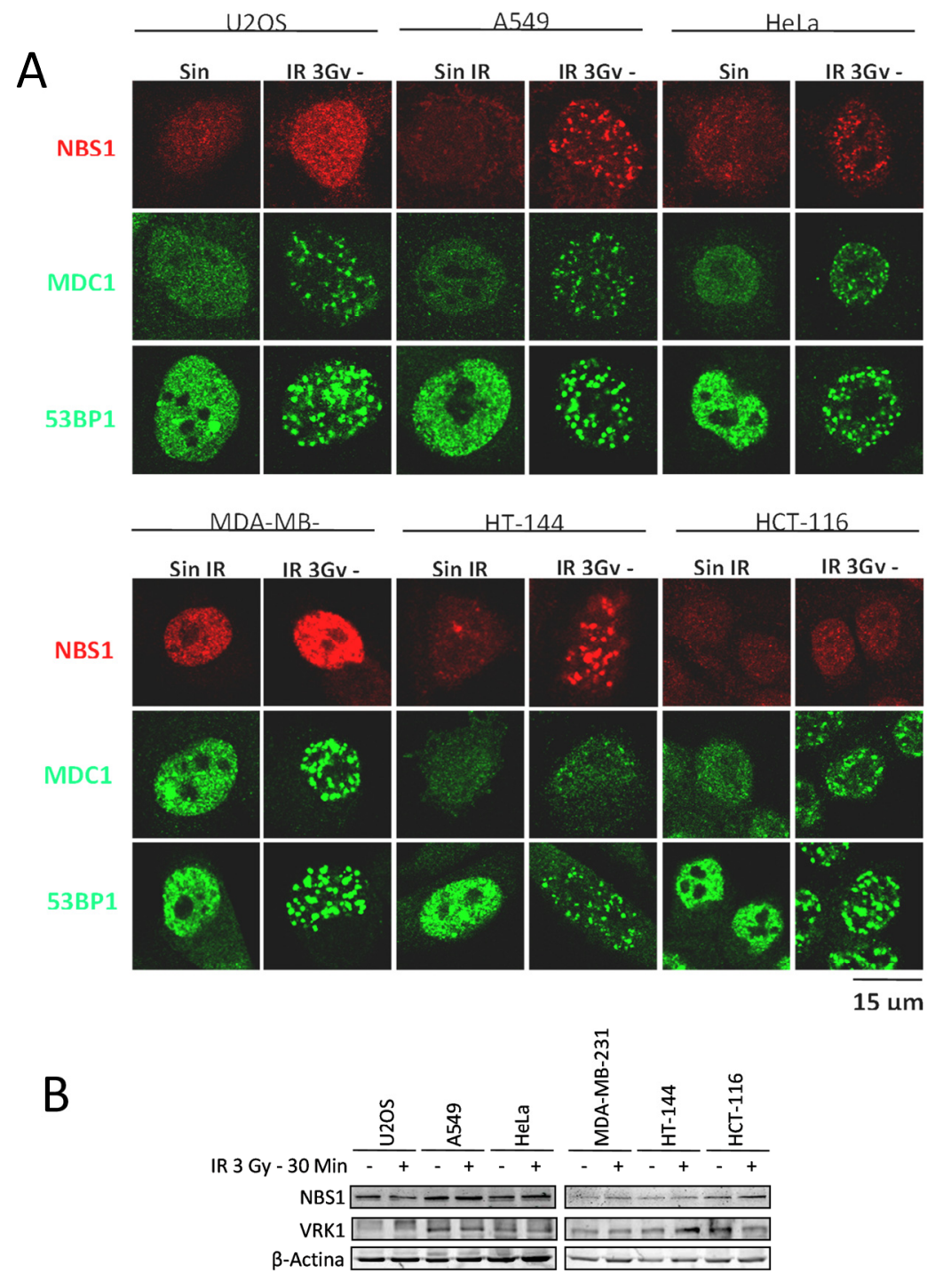

Figura 29. Efecto de la radiación ionizante sobre proteínas involucradas en la respuesta al daño del ADN. A. Células U2OS (osteosarcoma), A549 (carcinoma de pulmón), Hela (adenocarcinoma de cérvix), MDA-MB-231 (cáncer de mama), HT-144 (Melanoma ATM-/-) y HCT-116 (carcinoma colorectal) fueron irradiadas con una dosis de 3 Gy o dejadas sin irradiar. Después de 30 minutos de recuperación las células fueron fijadas y procesadas para inmunofluorescencia. Se utilizaron los anticuerpos anti-MDC1 policlonal, anti-NBS1 monoclonal y anti-53BP1 policlonal. La barra indica $15 \mu \mathrm{m}$. B. Análisis por Western blot de los niveles de expresión de VRK1 y NBS1 en las diferentes líneas celulares utilizadas en el apartado A, en ausencia o presencia de daño producido por IR. Se marcaron los niveles de $\beta$ Actina como control de carga. 
Para la continuación de este trabajo y los futuros resultados escogimos de entre todas las líneas celulares del panel anterior la línea de carcinoma de pulmón A549. Esta elección fue determinada por el hecho de que es una línea de fácil manejo en el laboratorio, además de expresar altos niveles de NBS1 y VRK1 endógenos en comparación con otras líneas celulares.

\subsubsection{Formación de focos de reparación a diferentes dosis de radiación ionizante}

Dado los resultados obtenidos del efecto de la radiación ionizante sobre los diferentes tipos celulares, quisimos probar el efecto de diferentes dosis de irradiación gamma sobre la formación de focos de NBS1, yH2AX y 53BP1 en la línea celular A549. Para llevar a cabo este ensayo, se irradiaron células A549 con 3, 6 y 10 Gy de radiación ionizante, y después de 30 minutos de recuperación, las células se fijaron para inmunofluorescencia. Como podemos observar en la figura 30A, el número de focos de NBS1, $\mathrm{YH} 2 \mathrm{AX}$ y 53BP1 incrementa linealmente de manera dosis dependiente. De este modo, comprobamos que a medida que la dosis de radiación ionizante incrementa, son más las DSBs que se forman y, por lo tanto, es directamente proporcional a la formación de los focos de reparación, tal y como se describe en la literatura. Adicionalmente, estudiamos los niveles de expresión de NBS1 y VRK1 en diferentes líneas celulares estimuladas con 3, 6 y 10 Gy de radiación ionizante con el fin de verificar si, al igual que el resultado de la figura 29B (pág. 96), no había efecto de la irradiación sobre los niveles totales de estas proteínas. Efectivamente, encontramos que la radiación ionizante no afectaba los niveles de expresión de NBS1 ni VRK1 en las líneas celulares estudiadas (Figura 30B). Dentro de nuestra proteína de interés, NBS1, existe un residuo de fosforilación (serina 343) dependiente de radiación ionizante. Aunque los niveles totales de NBS1 no se afectan tras el estímulo con diferentes dosis de irradiación, quisimos comprobar si dicho residuo aumentaba su fosforilación de manera dosis dependiente verificando la efectividad de la irradiación. Para ello llevamos a cabo un ensayo de Western blot con un anticuerpo fosfo específico p-Serina 343 de NBS1. Efectivamente confirmamos el incremento en los niveles de fosforilación en esta serina sin verse afectados los niveles totales de la proteína (Figura 30C). 


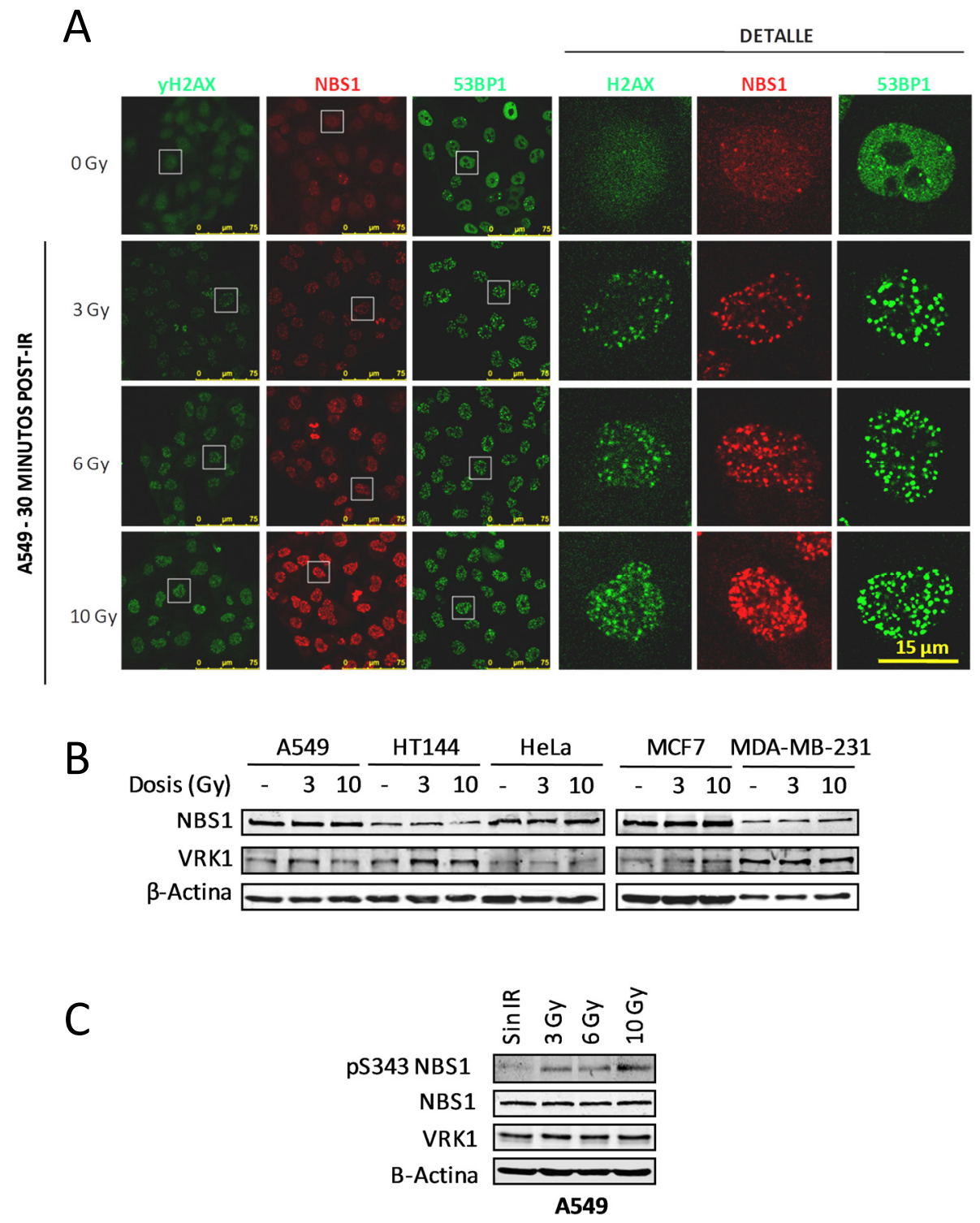

Figura 30. Efecto de diferentes dosis de radiación ionizante. A. Células A549 fueron tratadas con diferentes dosis de radiación gamma ( $3 \mathrm{~Gy}, 6$ Gy y $10 \mathrm{~Gy}$ ). Después de 30 minutos de recuperación, las células fueron fijadas y analizadas por inmunofluorescencia. Se utilizaron los anticuerpos anti-yH2AX monoclonal, anti-NBS1 monoclonal y anti-53BP1 policlonal. B. Western blot representativos mostrando los niveles totales de NBS1 y VRK1 en diferentes líneas celulares (A549, HT144 (ATM-/-), HeLa, MCF7 y MDA-MB-231) irradiadas con 3 Gy o $10 \mathrm{~Gy}$ o dejadas sin irradiar. Se prepararon los lisados 30 minutos después de la irradiación. Se utilizaron los anticuerpos anti-VRK1 1 b5 y anti-NBS1. C. Detección de la fosforilación de NBS1 en el residuo serina 343 tras radiación ionizante a diferentes dosis ( 3 Gy, 6 Gy y 10 Gy) en la línea celular A549. 


\subsubsection{Cinética de formación de focos de reparación en respuesta a radiación ionizante}

Varias proteínas de la respuesta al daño en el ADN se reclutan a los sitios de lesión rápidamente, formando los focos de reparación que pueden ser detectados por inmunofluorescencia. Monitorizamos en una curva de tiempo el reclutamiento $y$ posterior acumulación de proteínas como NBS1, MDC1 y 53BP1 a los sitios de DSBs, después de estimular a las células A549 con 3 Gy de radiación ionizante. De igual manera, observamos la cinética de la fosforilación del residuo serina 139 de la histona $\mathrm{H} 2 \mathrm{AX}$ ( $\mathrm{\gamma H} 2 \mathrm{AX}$ ), importante en la detección del daño, ya que sirve como señal epigenética para identificar el número y la localización de las DSBs (Nakamura et al, 2010). En la figura 31 (pág. siguiente, pie de figura en pág. 101) observamos que 5 minutos después de haber irradiado las células A549, se formaron focos de $\mathrm{pH} 2 \mathrm{AX}$, siendo lo esperado, ya que según la literatura estos focos se forman en pocos minutos después de la irradiación (Mariotti et al, 2013). Por otro lado, NBS1 también es reclutado a los sitios de lesión rápidamente (5 minutos post-irradiación), manteniéndose constante hasta 30 minutos después de irradiar, para luego disminuir el número de focos a partir de 1 hora. MDC1 y 53BP1 también se reclutan rápidamente, pero en este caso, se observó que el número máximo de formación de focos para ambas proteínas es de 15 y 30 minutos, respectivamente. El número de focos de todas las proteínas estudiadas tiene un comportamiento similar, ya que van disminuyendo al transcurrir el tiempo. Sin embargo, algunos focos persisten en el tiempo e incrementan su tamaño. Estos focos, también conocidos como focos residuales, son sitios de $A D N$ dañado que no se han podido reparar y por tal motivo tienen mayor acumulación de proteínas de reparación. 


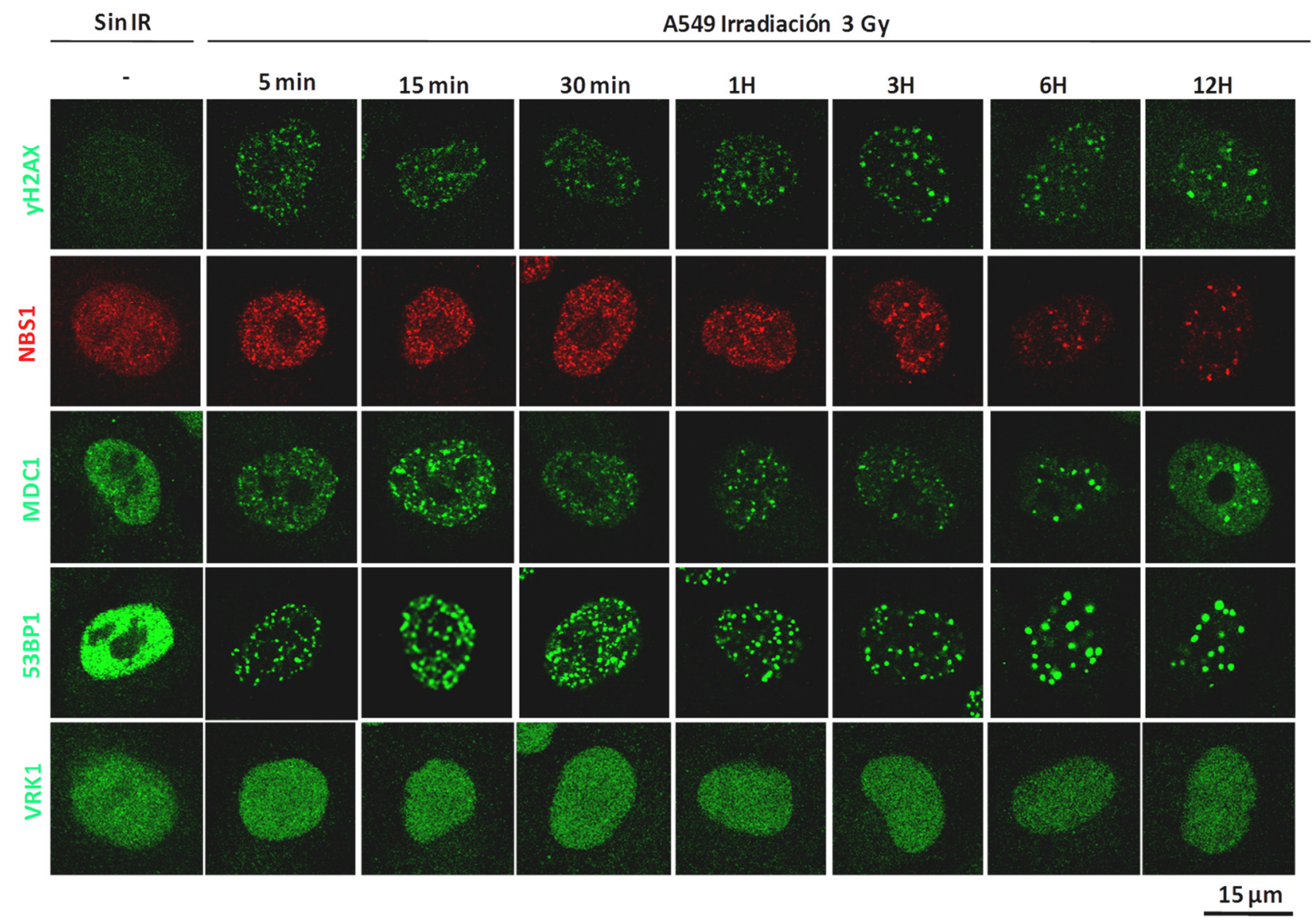


Figura 31. Cinética de la formación de focos de yH2AX, NBS1, MDC1 y 53BP1 en respuesta a radiación ionizante con 3 Gy. Células A549 fueron tratadas con 3 Gy de radiación gamma. Tras la recuperación a diferentes tiempos entre 5 minutos y 12 horas, las células fueron fijadas para inmunofluorescencia. Se utilizaron los anticuerpos anti-yH2AX monoclonal, anti-MDC1 policlonal, anti-NBS1 monoclonal y anti-53BP1 policlonal. La barra indica $15 \mu \mathrm{m}$.

\subsection{Papel de VRK1 sobre la proteína mediadora MDC1 en respuesta al daño en el ADN}

En estudios realizados en el laboratorio, se identificó la quinasa humana VRK1 como una proteína importante en la respuesta al daño en el ADN. Se encontró que VRK1 responde rápidamente a estímulos que producen daño génico. Además, fosforila e interacciona con la proteína mediadora 53BP1, ayudando a su correcto reclutamiento a los focos de respuesta al daño producidos por radiación ionizante, de manera independiente de p53 y ATM (Sanz-Garcia et al, 2012). En primer lugar, reproducimos estos resultados en células A549, suprimiendo la expresión de la quinasa VRK1 con un ARN de interferencia específico (Si-VRK1) y utilizando un ARN sin diana específica como control (Si-C). Después de 96 horas, tiempo en el cuál se obtiene una disminución drástica de los niveles proteicos de VRK1, las células fueron irradiadas con 3 Gy de radiación gamma y se observó la formación de focos de 53BP1 por inmunofluorescencia. Como se muestra en la figura 32A, confirmamos que ciertamente VRK1 es necesaria para el reclutamiento de 53BP1 a las DSBs, ya que en las células deficientes de VRK1, 53BP1 no se localizaba en los focos de reparación, en comparación con las células no transfectadas (MOCK) o transfectadas con Si-C, donde se observó la formación de focos discretos y definidos de 53BP1. Por otro lado, para detallar el efecto del silenciamento de VRK1, cuantificamos el número de focos de 53BP1 por célula tras irradiar. Las células fueron analizadas con el programa ImageJ (http://rsb.info.nih.gov/ii), en el cual se realizó el contaje de los focos. Las células sin transfectar y las células transfectadas con si-C presentaron una media similar de 28-30 focos de 53BP1 tras irradiación, sin embargo, las células transfectadas con siVRK1 presentaron una media de 18 focos de 53BP1 (Figura 32B). Por lo tanto, se reafirma la importancia de VRK1 en la formación de los focos de 53BP1.

Adicionalmente, quisimos comprobar si este efecto era similar con otros tipos de estímulo. Para esto, se trataron células A549 con doxorubicina o hidroxiurea, dos agentes utilizados en el tratamiento contra el cáncer. Observamos que después de dos horas de tratamiento con doxorubicina $1 \mu \mathrm{M}$ se formó el mayor número de focos discretos de 53BP1, de forma contraria, la hidroxiurea no tuvo un fuerte efecto 
A

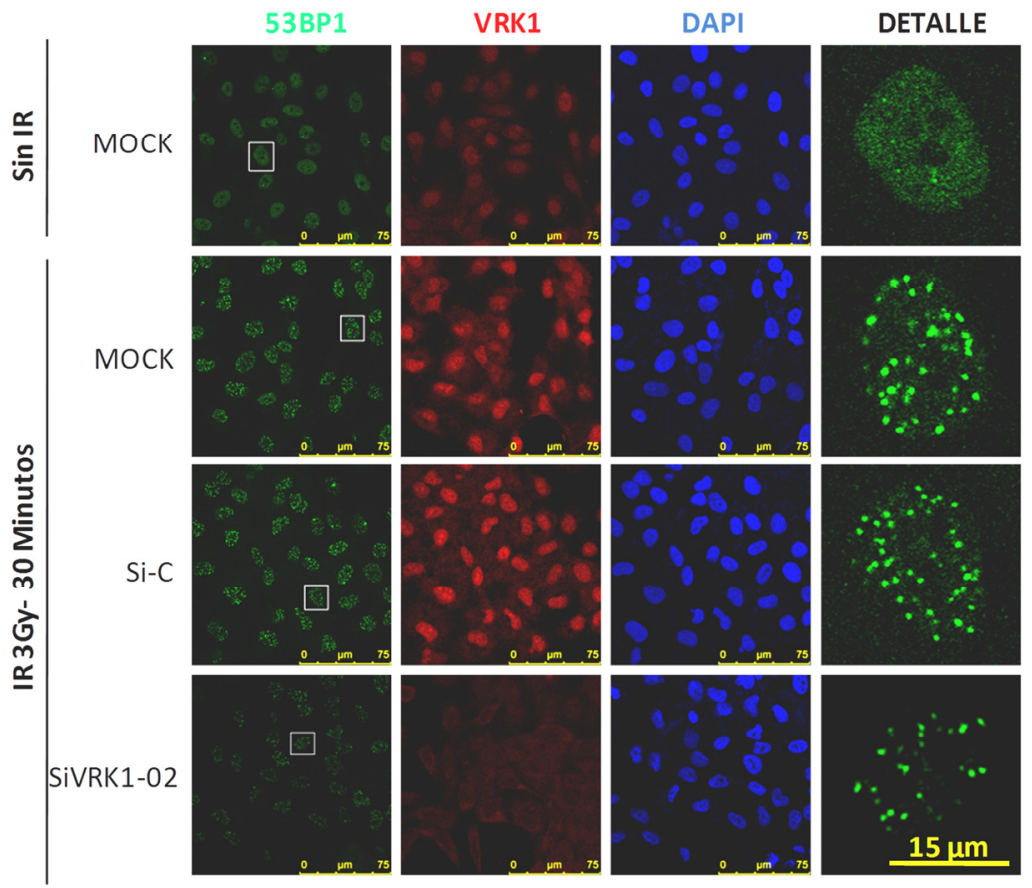

B

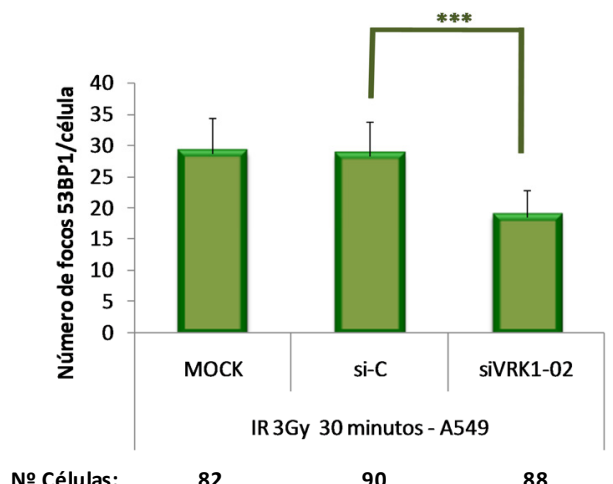

Figura 32. El silenciamiento de la quinasa humana VRK1 afecta la formación de focos de 53BP1 en respuesta a radiación ionizante. A. Células A549 fueron transfectadas con ARN control (Si-C) o ARN de interferencia específico para VRK1 (SiVRK1-02). Después de 96 horas de transfección, las células fueron irradiadas con una dosis de 3 Gy o dejadas sin irradiar. Tras 30 minutos de recuperación, las células fueron fijadas para realizar ensayos de inmunofluorescencia. 53BP1 se detectó en verde con un anticuerpo policlonal, y VRK1 en rojo con el anticuerpo monoclonal 1b5. Los núcleos se tiñeron con DAPI. La barra indica $20 \mu \mathrm{m}$. B. Representación gráfica de la cuantificación del número de focos de 53BP1, en torno a 90 células por cada punto del apartado $\mathrm{A}$. Se indican las medias y desviaciones estándar de las medidas. Los datos fueron analizados mediante $t$ student $* * * p<0,0005$. 
sobre la formación de focos de 53BP1, probablemente porque depende de la facilidad de penetración a la célula (Figura 33A y B). Por tal motivo, escogimos el tratamiento con doxorubicina para probar el silenciamiento de VRK1 sobre los focos de 53BP1. Obtuvimos resultados similares a los del tratamiento con radiación ionizante, al silenciar VRK1 se vió una fuerte disminución en el número de focos de 53BP1 tras el tratamiento con doxorubicina (Figura 33C). Concluimos, por lo tanto, que VRK1 es necesaria para el correcto ensamblaje de focos de 53BP1 en respuesta a radiación ionizante y fármacos como la doxorubicina.

A

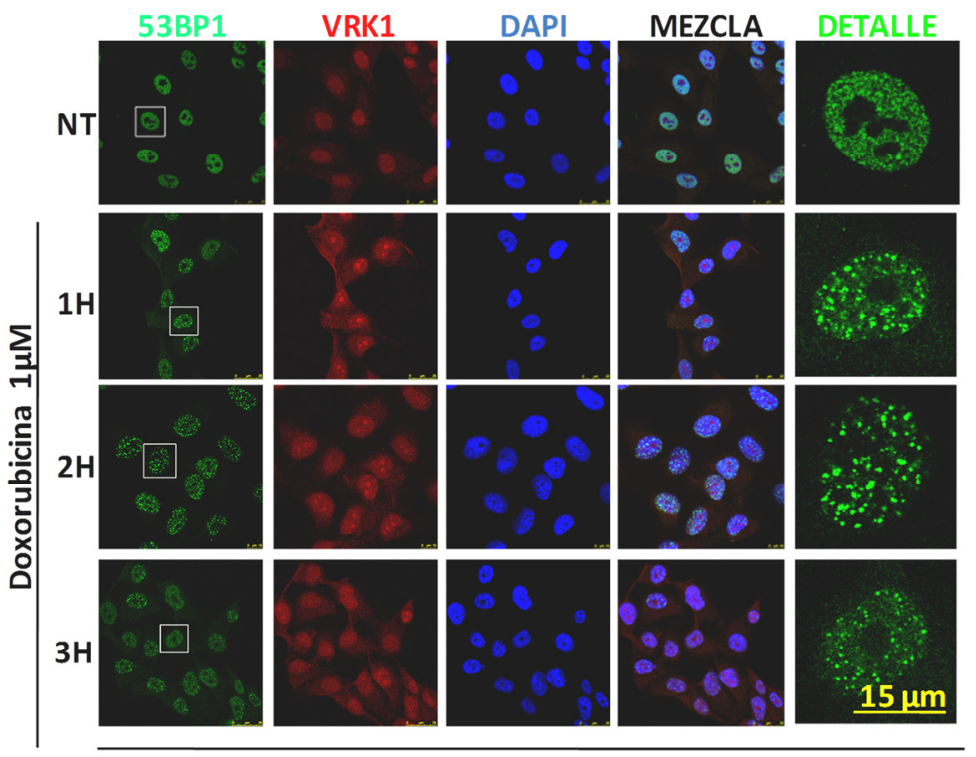

Línea celular A549

Figura 33. Localización de 53BP1 en focos inducidos por fármacos y efecto del silenciamiento de VRK1. A y B. Se trataron células A549 con doxorubina $1 \mu \mathrm{M}$ o hidroxiurea $1 \mu \mathrm{M}$ a diferentes tiempos. Posteriormente, las células fueron fijadas y preparadas para inmunofluorescencia. Se observó la cinética de la formación de focos de 53BP1 con un anticuerpo policlonal específico (verde) y se detectó VRK1 con el anticuerpo monoclonal 1b5 (rojo). Los núcleos se tiñeron con DAPI. La barra indica $15 \mu \mathrm{m}$. NT: células no tratadas. C. Células A549 fueron tratadas con doxorubina $1 \mu \mathrm{M}$ durante 1 y 3 horas después de 96 horas de transfección con Si-C o Si-VRK1. Se realizó inmunofluorescencia con anticuerpos específicos anti-53BP1 (verde) y anti-VRK1 1b5 (rojo). Los núcleos fueron teñidos con DAPI. NT: células no tratadas. 
B

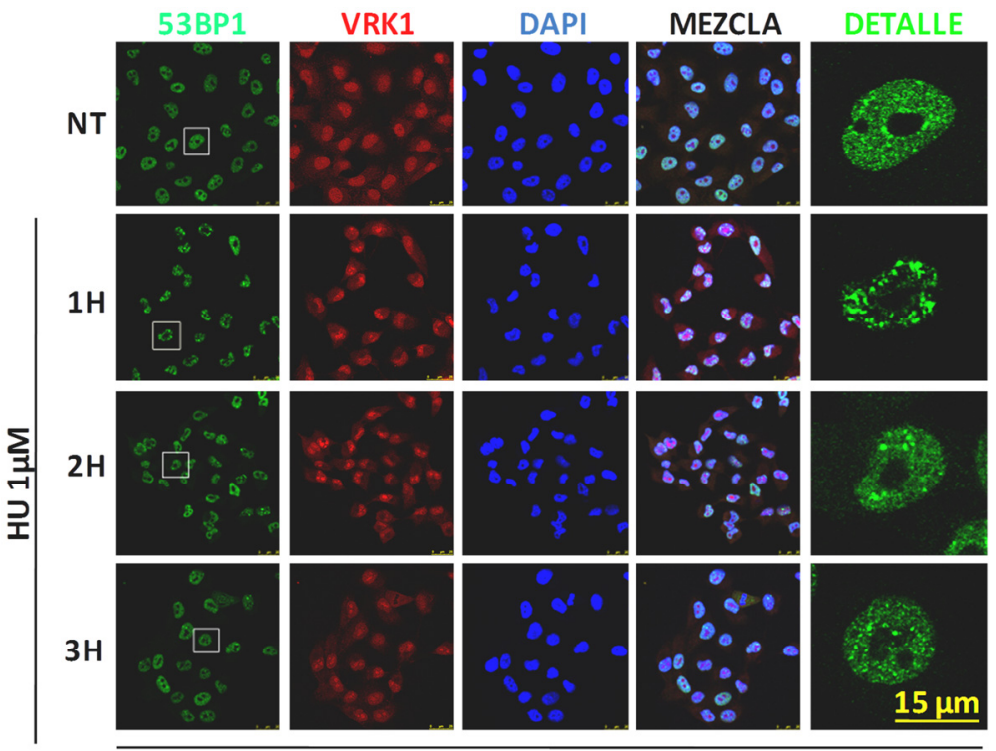

Línea celular A549

C

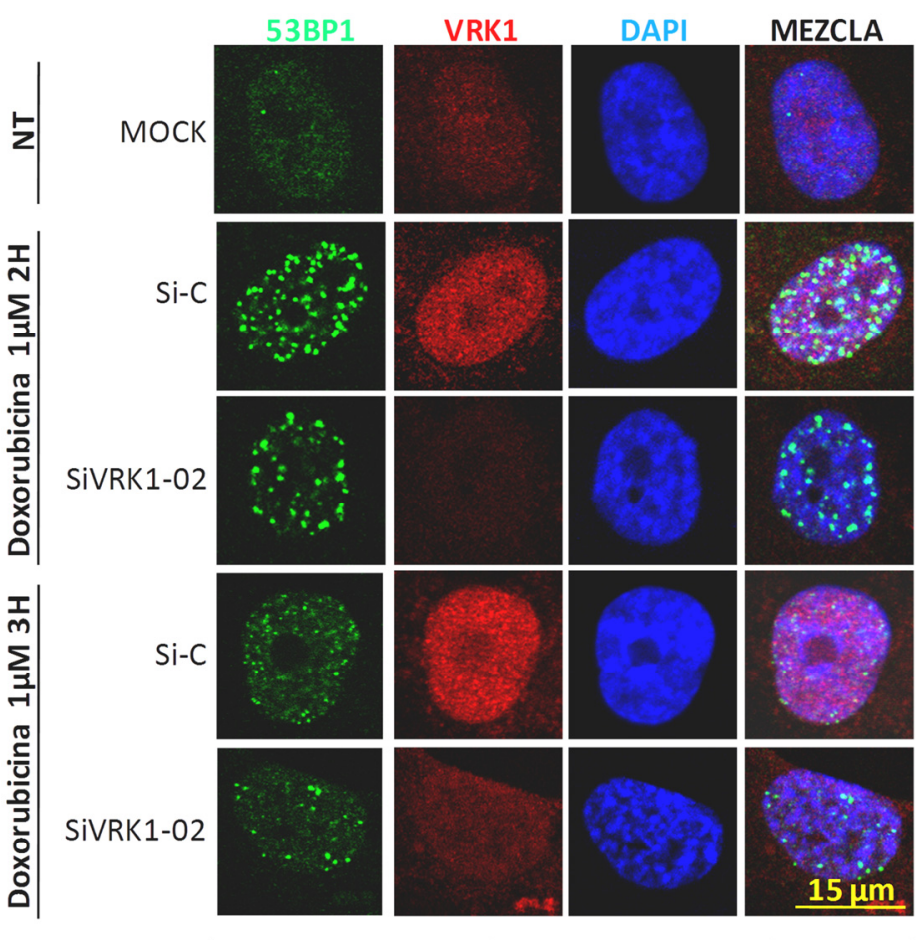

Línea celular A549 


\subsubsection{VRK1 interacciona con MDC1 pero no afecta su reclutamiento a los focos de reparación en respuesta al daño génico}

Puesto que ya conocemos la función de VRK1 en el reclutamiento de la proteína mediadora 53BP1 a los sitios de lesión, nos planteamos la posibilidad de que VRK1 pudiera afectar a otra proteína mediadora como MDC1 que se encuentra upstream de 53BP1. El reclutamiento y ensamblaje de focos de 53BP1 es controlado por la interacción directa entre ambas proteínas (Bekker-Jensen et al, 2005). En primer lugar, probamos si existía interacción entre VRK1 y MDC1. Para ello, se transfectaron células HEK-293T con los plásmidos pCDNA3-HA-MDC1, pCEFL-GST-VRK1 y pCEFLGST vacío, en las combinaciones que se observan en la figura 34 . Se inmunoprecipitó la proteína HA-MDC1 y se detectó por Western blot la presencia de GST-VRK1 en el precipitado. Los resultados muestran la interacción entre ambas proteínas de manera independiente al daño en el ADN producido por el tratamiento con doxorubicina.

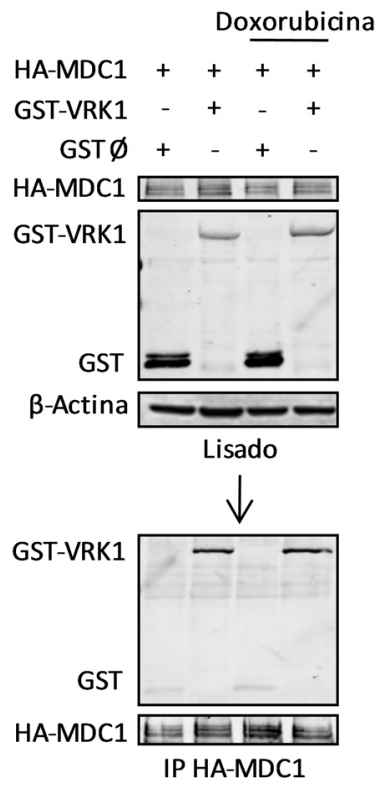

Figura 34. La proteína mediadora del daño en el ADN MDC1 interacciona con la quinasa humana VRK1. A. Células HEK-293T fueron transfectadas con los plásmidos pCEFL-GST o pCEFLGST-VRK1 en combinación con la construcción pCDNA3-HA-MDC1, durante 48 horas. Posteriormente se trataron las células con doxorubicina 1 $\mu \mathrm{M}$ durante 2 horas. Se prepararon los extractos celulares $y$ se inmunoprecipitó la proteína HA-MDC1 con el anticuerpo policlonal anti-HA. Se detectó por Western blot la presencia de GST-VRK1 en el precipitado con un anticuerpo monoclonal anti-GST.

Posteriormente, quisimos analizar el efecto del silenciamiento de VRK1 sobre los niveles totales de la proteína MDC1, para lo cual transfectamos células A549 con Si-C y SiVRK1-02. 72 horas después, las células fueron irradiadas con una dosis de 3 Gy. Transcurridos 30 minutos o 1 hora después de la irradiación, se lisaron las células y se detectaron los niveles proteicos de MDC1 y VRK1 en el Western blot. No observamos cambios en los niveles de expresión proteica de MDC1, por lo que 
concluimos que el silenciamiento de VRK1 no altera los niveles proteicos, aunque se produzcan DSBs por radiación ionizante (Figura 35A y B).

A

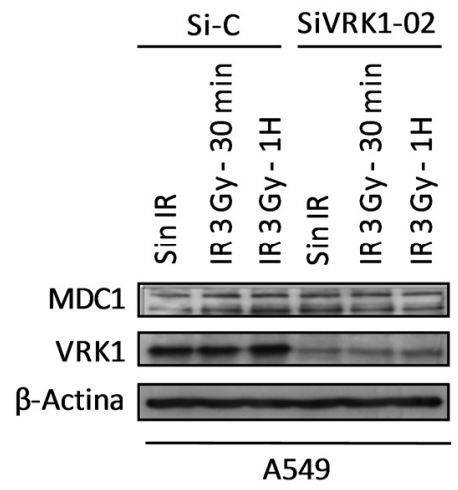

B

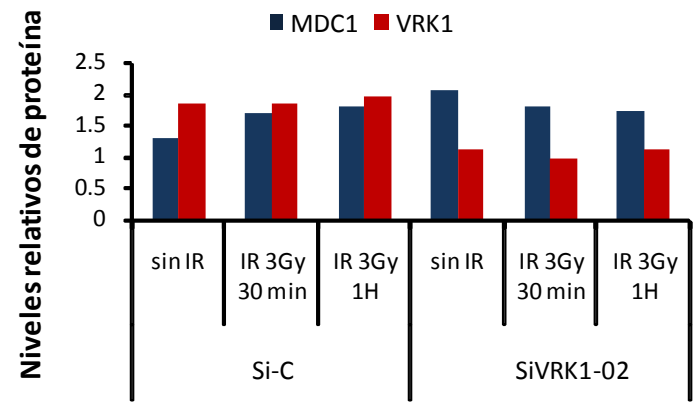

Figura 35. El silenciamiento de VRK1 en células A549 no afecta los niveles de expresión de la proteína MDC1. A. Células A549 fueron transfectadas con los correspondientes oligonucleótidos de ARN de interferencia. 72 horas después las células fueron irradiadas con una dosis de $3 \mathrm{~Gy}$ y se recogieron los extractos después de 30 minutos o una hora. Se analizaron por Western blot los niveles de MDC1 con un anticuerpo monoclonal y VRK1 con el anticuerpo policlonal VC. B. En la gráfica se muestra la cuantificación y normalización con respecto a la $\beta$-Actina de la expresión de MDC1 y VRK1, utilizando el programa Quantity One de BIORAD.

Este resultado, sin embargo, no nos revela si VRK1 puede ser importante para el reclutamiento de MDC1 en los focos de reparación. Para ello, procedimos a realizar una inmunofluorescencia en células A549 transfectadas con Si-C, SiVRK1-02 o dejadas sin transfectar (MOCK). Después de 96 horas, las células fueron tratadas con $1 \mu \mathrm{M}$ de doxorubicina durante 2 horas para producir DSBs. Se observó que, en ausencia de estímulo, MDC1 se localizaba de forma difusa en el núcleo y era después de la estimulación con doxorubicina que se detectaba su acumulación en los puntos de rotura, tal y como se describe en la bibliografía (Figura 36A). El uso del ARN de interferencia siVRK1-02 produjo una disminución significativa en los niveles de VRK1 (Figura 36A y B), pero no se observó efecto del silenciamiento de esta quinasa sobre el reclutamiento de MDC1 a los sitios de lesión (Figura 36 A). Adicionalmente, se cuantificó el número de focos de MDC1 en las diferentes condiciones con el programa ImageJ para confirmar el resultado obtenido (Figura $36 \mathrm{C}$ ). 


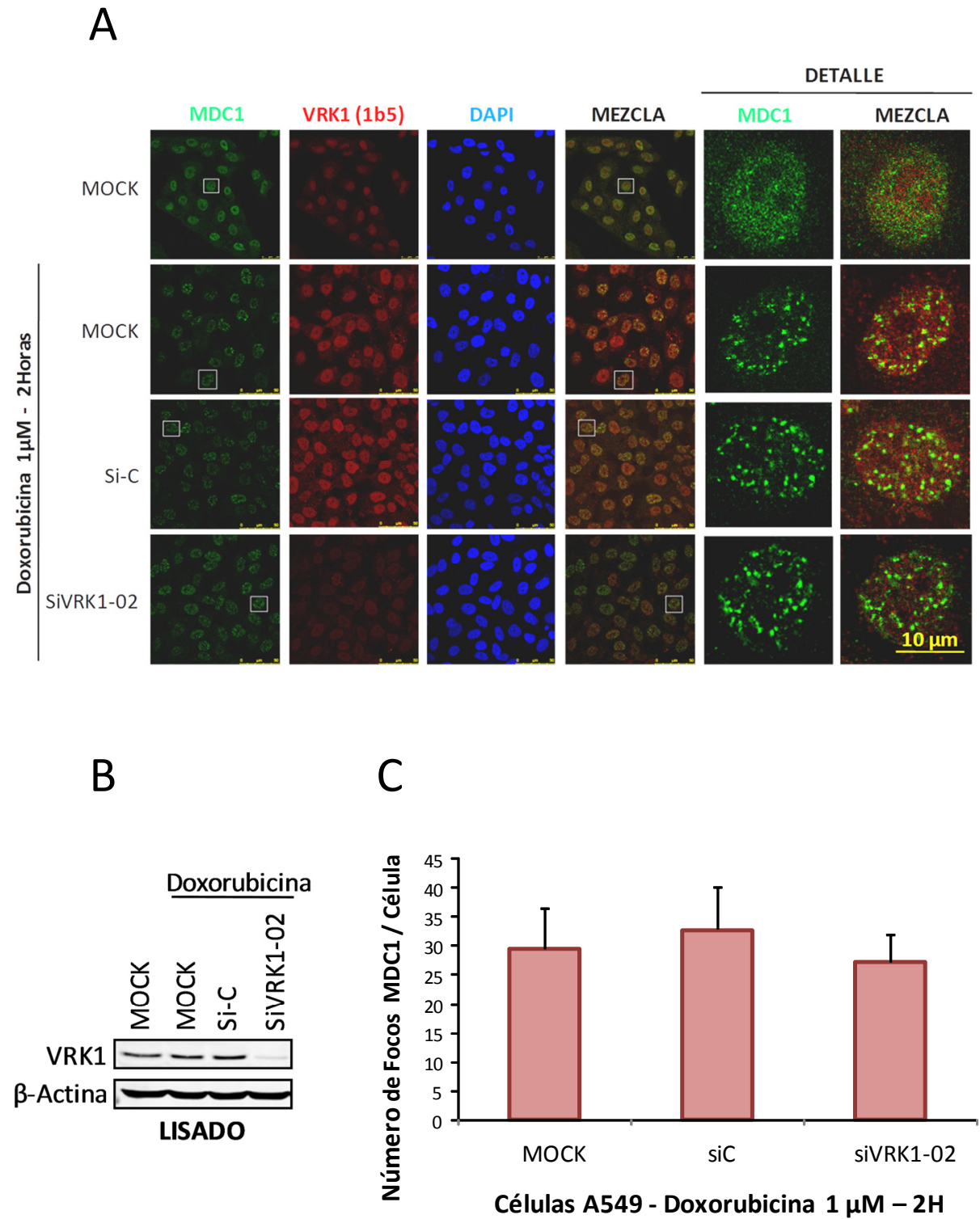

Figura 36. El silenciamiento de la quinasa humana VRK1 no afecta la formación de los focos de MDC1. A. Células A549 fueron transfectadas con ARN control o ARN de interferencia específico para VRK1 durante 96 horas. Posteriormente, las células fueron tratadas con doxorubina $1 \mu \mathrm{M}$ durante 2 horas o dejadas sin tratar. Se procesaron los cubreobjetos de vidrios con las células para inmunofluorescencia. Se detectó la proteína MDC1 con un anticuerpo policlonal (verde) y VRK1 con el anticuerpo monoclonal 1b5 (rojo). Los núcleos fueron teñidos con DAPI (azul). Se muestra en detalle los focos de MDC1 en una célula representativa de cada punto. La barra indica $10 \mu \mathrm{m}$. B. Detección por Western blot de los niveles de VRK1 correspondientes a las células fijadas en la gráfica A. C. Representación gráfica de la cuantificación del número de focos de MDC1 inducidos por doxorubicina tras el silenciamiento de VRK1. Se indican las medias v desviaciones estándar. 


\subsubsection{VRK1 es necesaria para el ensamblaje de focos de 53BP1 pero no de MDC1}

Las proteínas mediadoras funcionan como proteínas adaptadoras, ayudando al reclutamiento de diferentes miembros de la respuesta al daño en el ADN (DDR) facilitando la transducción de señales. Como se mencionó anteriormente, la interacción directa entre MDC1 (dominios BRCT) y 53BP1 (residuos 1288-1409) es necesaria para el reclutamiento de 53BP1 en las DSBs (Eliezer et al, 2009). Por tal motivo, estudiamos el papel de VRK1 en la formación de focos y colocalización de MDC1 y 53BP1 en células A549 en respuesta a doxorubicina. Después de obtener una disminución drástica en los niveles de VRK1 (Figura 37B) en células A549 transfectadas con Si-C, SiVRK1-02 o dejadas sin transfectar, las células fueron tratadas con $1 \mu \mathrm{M}$ de doxorubicina durante 2 horas. Al igual que en los resultados anteriores, no se observaron diferencias entre los focos de MDC1 de las células control o las células con bajos niveles de expresión de VRK1, en comparación con los focos de 53BP1, los cuales si fueron afectados por el silenciamiento de VRK1 (Figura $37 \mathrm{~A}$ y C). Además, se observó que ambas proteínas colocalizan en la mayoría de los focos de reparación, incluso en las células transfectadas con SiVRK1-02, 53BP1 que sigue formando focos colocaliza con MDC1 (Figura 37A).

Figura 37. El silenciamiento de VRK1 afecta la formación de focos de 53BP1 pero no de MDC1 en respuesta al tratamiento con doxorubicina. A. Detección de 53BP1 y MDC1 en células A549 tratadas o no con doxorubicina (1 $\mu \mathrm{M}$ durante 2 horas) después de la transfección con Si-C, SiVRK1-02 o dejadas sin transfectar (MOCK). En la inmunofluorescencia se utilizaron los anticuerpos anti-MDC1 monoclonal (rojo) y anti-53BP1 policlonal (verde), los núcleos se tiñeron con DAPI (Azul). Se muestra en detalle la formación de focos de MDC1 y 53BP1, así como el solapamiento de ambas proteínas. B. Western Blot de la expresión de VRK1 en las células A549 empleadas en el apartado A. C. Representación gráfica de la cuantificación del número de focos de MDC1 y 53BP1 por cada punto del apartado A. Se representan las medias y desviaciones estándar. En la parte superior se indica el número de células utilizadas en la cuantificación. 

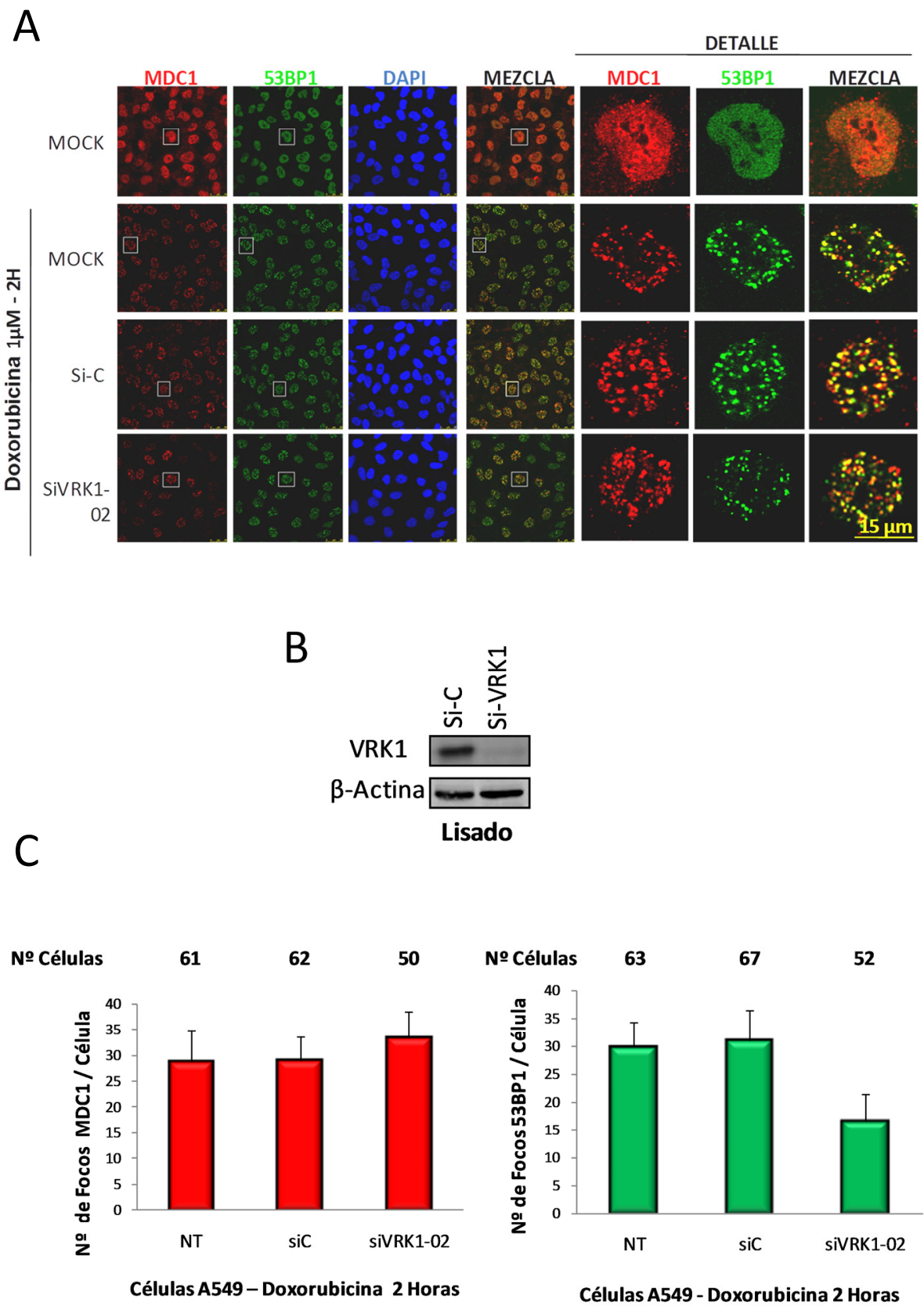

Adicionalmente, para confirmar el efecto de VRK1 sobre el reclutamiento de MDC1 a las DSBs, se realizó una inmunofluorescencia de células A549 transfectadas con Si-C, SiVRK1-02 o dejadas sin transfectar (MOCK). En esta ocasión, las células fueron estimuladas con 3 Gy de radiación ionizante y dejadas recuperar durante 30 minutos. Confirmamos el resultado obtenido anteriormente con el tratamiento de 
doxorubicina, ya que tal como esperábamos, no observamos cambios en la acumulación de MDC1 a los sitios de lesión en células deficientes de VRK1 (Figura 38A) (Sanz-Garcia et al, 2012).

A
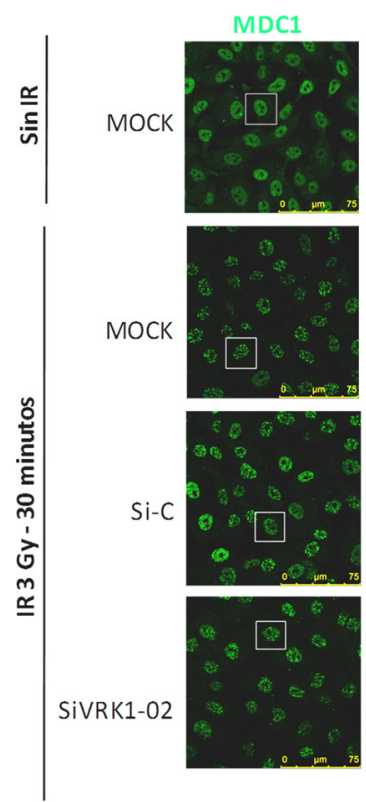

B

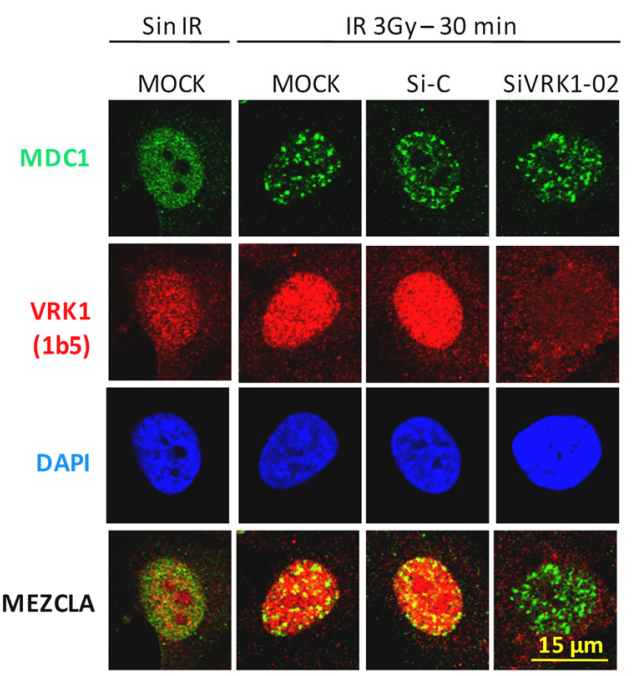

C
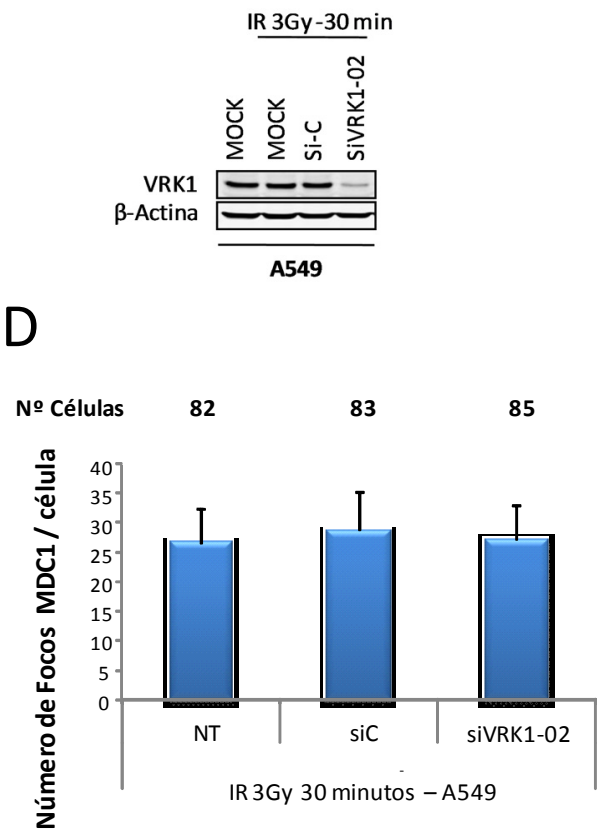
Figura 38. El silenciamiento de VRK1 no afecta la formación de focos de MDC1 en respuesta a radiación ionizante. A. Células A549 fueron transfectadas con ARN control o ARN de interferencia específico para VRK1. 96 horas después de la transfección, las células fueron irradiadas con 3 Gy de radiación gamma y se dejaron recuperar durante 30 minutos. Posteriormente, las células fueron fijadas para inmunofluorescencia. Se utilizaron los anticuerpos anti-MDC1 policlonal y 1 b5 monoclonal para detectar MDC1 (verde) y VRK1 (rojo), respectivamente. Se muestra en detalle los focos de MDC1 en una célula por cada punto del experimento. Los núcleos fueron teñidos con DAPI. La barra indica $15 \mu \mathrm{m}$. B. Igual que en (A), detalle de la formación de focos de MDC1 en una célula. C. Análisis por Western blot de los niveles de expresión de VRK1 de las células empleadas en el apartado A. D. Cuantificación del número de focos de MDC1 por cada punto del apartado A usando el programa ImageJ.

En la figura 38B podemos observar en más detalle que no existe colocalización entre VRK1 y MDC1. A modo de control, se detectó la eficiencia del silenciamiento de VRK1 por Western blot (Figura 38C) y se cuantificó el número de focos de MDC1. En torno a unas 80 células por punto fueron analizadas en el programa ImageJ. Se obtuvo una media de 28 focos de MDC1 en todas las condiciones estudiadas (Figura 38D).

\subsection{VRK1 y la proteína NBS1}

\subsubsection{VRK1 interacciona con NBS1 independiente del daño en el ADN}

La rápida activación de VRK1 en respuesta al daño en el ADN, así como su participación en el correcto ensamblaje de focos de proteínas mediadoras como 53BP1, hace pensar que VRK1 podría actuar en el inicio de la cascada de señalización, concretamente promoviendo la actividad de proteínas implicadas en la detección del daño (proteínas sensores) como el complejo MRN, específicamente la proteína NBS1. NBS1 se caracteriza por no tener actividad enzimática, pero si por regular las funciones del complejo MRN, ayudando a reclutar ordenadamente gran variedad de proteínas que median el proceso de reparación. Como primer acercamiento, estudiamos si NBS1 interaccionaba con VRK1 en respuesta a daño en el ADN o en ausencia de este. Para ello, probamos si la interacción se detectaba con las proteínas endógenas en las líneas celulares HEK-293T y A549. Extractos de células sin tratamiento y células tratadas con doxorubicina $1 \mu \mathrm{M}$ durante 2 horas, fueron incubados con el anticuerpo anti-NBS1. La presencia de VRK1 se detectó en el precipitado por Western blot. Observamos en ambas líneas celulares, la interacción entre VRK1 y NBS1 independientemente del daño producido (Figuras 39A y B). A continuación, nos planteamos si esta interacción era dependiente o no de ATM, ya que esta proteína juega un papel clave en la respuesta a las DSBs, mediante la fosforilación de diferentes sustratos downstream que modulan los mecanismos de reparación. Así, los extractos de las líneas celulares HT144 (melanoma ATM-/-) y GM9607 (fibroblastos ATM-/-) fueron utilizados para detectar la interacción entre 
estas proteínas. Los resultados en la figura 39C y D indican que NBS1 y VRK1 interaccionan independientemente de ATM.

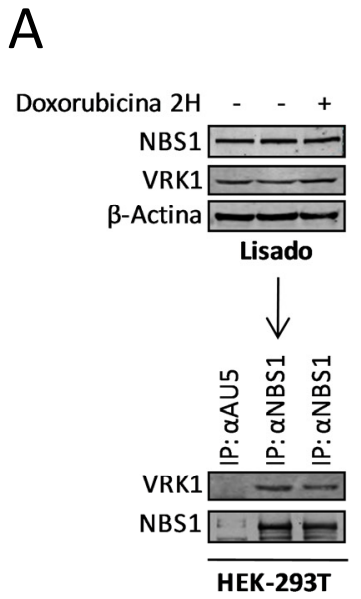

D

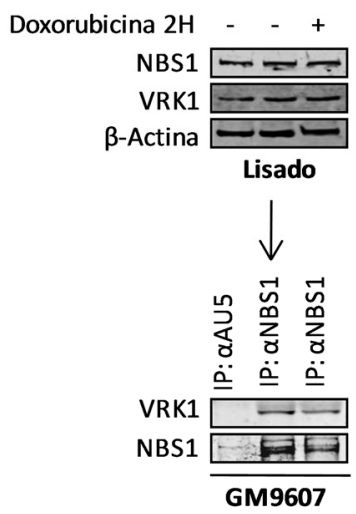

B

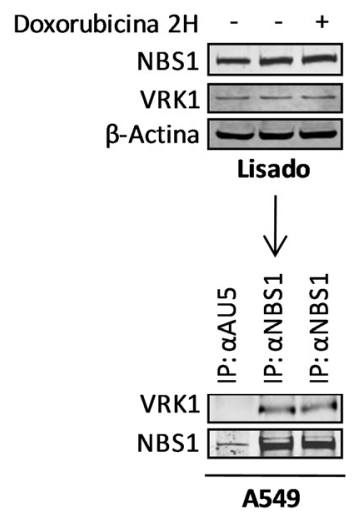

C

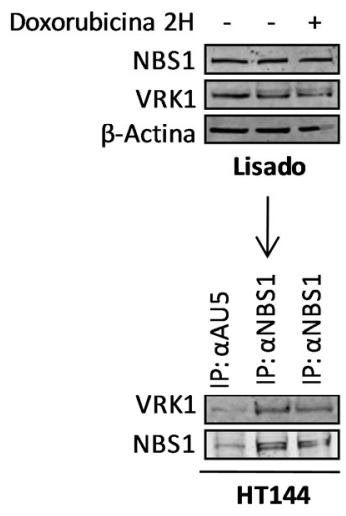

$E$

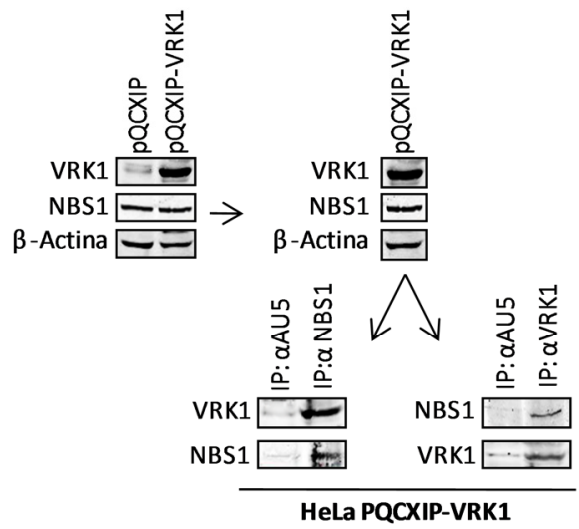

Figura 39. La proteína NBS1 del complejo MRN interacciona con la quinasa humana VRK1 independientemente del daño en el ADN. Detección de la interacción endógena entre las proteínas NBS1 y VRK1. 48 horas después del crecimiento de las células HEK-293T (A), A549 (B) y las células deficientes de ATM, HT144 (C) y GM9607 (D), fueron tratadas con doxorubicina $1 \mu$ M durante 2 horas o dejadas sin tratar. Las células fueron lisadas y el extracto fue utilizado para la inmunoprecipitación de NBS1 con el anticuerpo anti-NBS1 policlonal y su correspondiente inmunoprecipitación control con un anticuerpo policlonal anti-AU5. Se detectó por Western blot la presencia de VRK1 en el precipitado con el anticuerpo monoclonal $1 \mathrm{~b} 5$ y para el control de la inmunoprecipitación se usó el anticuerpo anti-NBS1 policlonal. En la gráfica E se realizó inmunoprecipitación recíproca de NBS1 y VRK1 en la línea celular estable HeLa pQCXIP-VRK1, que expresa elevados niveles de VRK1. Se inmunoprecipitó NBS1 con un anticuerpo policlonal específico para esta proteína y se usó como control el anticuerpo anti-AU5 policlonal (panel izquierda) o de manera contraria se inmunoprecipitó VRK1 con el anticuerpo monoclonal $1 \mathrm{~b} 5$ y como control de la inmunoprecipitación se utilizó el anticuerpo anti-AU5 monoclonal (panel derecha). Se detectaron VRK1 y NBS1 en el precipitado con anticuerpos específicos. 
Realizamos también ensayos de co-inmunoprecipitación de las proteínas endógenas, utilizando extracto de la línea celular estable HeLa, que expresa altos niveles de VRK1. Esta línea celular fue creada mediante la infección lentiviral del plásmido PQCXIP-VRK1 y posterior selección con el antibiótico de resistencia puromicina. Se inmunoprecipitó NBS1 (Figura 39E Izquierda) o VRK1 (Figura 39E derecha) con anticuerpos específicos para cada proteína. Como control de las inmunoprecipitaciones se utilizó un anticuerpo del mismo isotipo sin ninguna diana endógena. En los resultados se confirma la interacción entre ambas proteínas.

Con la intención de confirmar la interacción entre NBS1 y VRK1, decidimos estudiar si esta también se presentaba al transfectar una o ambas proteínas en diferentes condiciones experimentales. En primer lugar, probamos transfectando solo una proteína. Se transfectaron células HEK-293T con el plásmido pcDNA3.1-VRK1-Myc, el cual expresa la proteína VRK1 fusionada al epítopo Myc. En este caso se inmunoprecipitó NBS1 endógeno con un anticuerpo policlonal específico y se usó el anticuerpo monoclonal anti-Myc para detectar la presencia de VRK1-Myc en el Western blot. Este resultado nos muestra que NBS1 interacciona establemente con la proteína VRK1-Myc (Figura 40A). Posteriormente, se transfectaron células HEK293T y A549 con los plásmidos pIRES2-FLAG-NBS1 y pCEFL-HA-VRK1. Se comprobó la correcta expresión de las proteínas sobre-expresadas en el lisado (Figura $40 \mathrm{~B}$ y C). Los extractos celulares fueron incubados con el anticuerpo policlonal anti-FLAG para precipitar la proteína NBS1 y se detectó la presencia de VRK1 utilizando el anticuerpo monoclonal anti-HA. En ambas líneas celulares se observó como NBS1 y VRK1 interaccionan con o sin daño en el ADN producido por doxorubicina (Figura $40 B$ y $C)$.
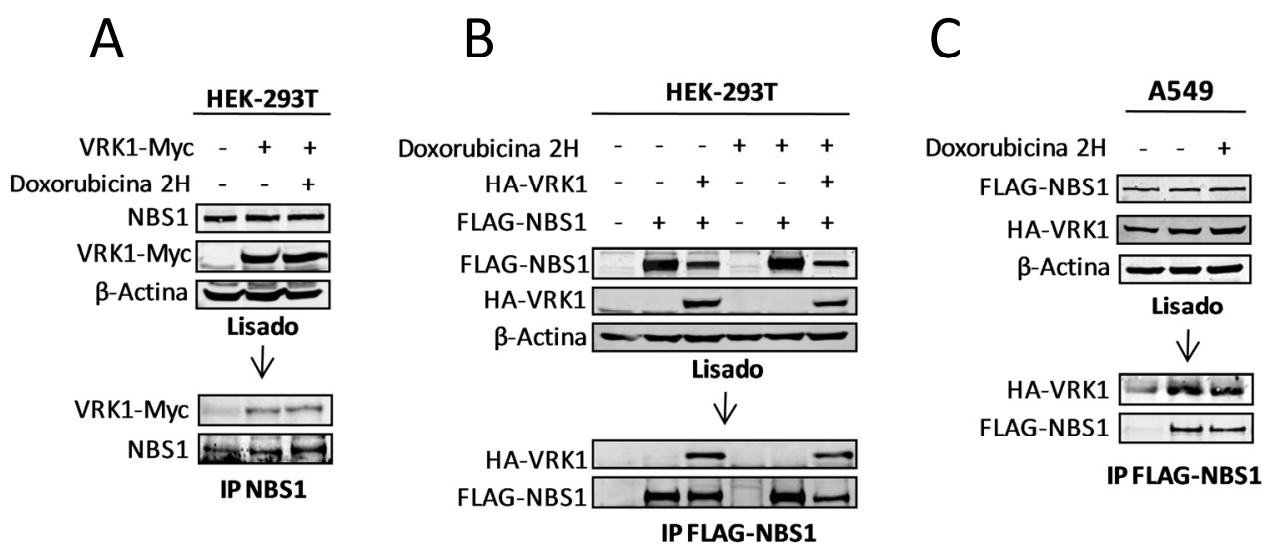
Figura 40. Validación de la interacción de NBS1 y VRK1. A. Se transfectaron células HEK-293T con los plásmidos pCEFL-HA y pcDNA3.1-VRK1-Myc. 48 horas después se realizó el tratamiento con doxorubicina $1 \mu \mathrm{M}$ durante 2 horas. Transcurrido el tiempo, las células fueron lisadas y el extracto se utilizó para realizar inmunoprecipitación de NBS1 endógeno con un anticuerpo policlonal específico. Se detectó la presencia de VRK1-Myc en el precipitado con el anticuerpo monoclonal anti-Myc. B. Células HEK-293T fueron transfectadas con pIRES2FLAG-NBS1 en combinación con pCEFL-GST-VRK1 durante 48 horas. Posteriormente las células fueron tratadas con doxorubicina $1 \mu \mathrm{M}$ durante 2 horas. Se inmunoprecipitó la proteína FLAGNBS1 y GST-VRK1 fue detectado en el precipitado. C. Células A549 fueron transfectadas con pIRES2-FLAG-NBS1 y pCEFL-HA-VRK1. 48 horas después, las células fueron tratadas con $1 \mu \mathrm{M}$ de doxorubicina durante 2 horas. El extracto celular se usó para inmunoprecipitar la proteína NBS1 con el anticuerpo policlonal anti-FLAG. Como control de la inmunoprecipitación se usó el anticuerpo policlonal anti-AU5. Se detectó por Western blot la presencia de HA-VRK1 en el precipitado con el anticuerpo monoclonal anti-HA.

Una vez hubimos confirmado la interacción entre NBS1 y VRK1, quisimos determinar si VRK1 era el único miembro de la familia VRK que podría interaccionar con NBS1. Llevamos a cabo experimentos de Pull-Down en la línea celular HEK-293T, transfectando el plásmido pCMV-Tag4b-FLAG-NBS1 en combinación con pCEFL-GST, pCEFL-GST-VRK1, pCEFL-GST-VRK2A y pCEFL-GST-VRK2B. Tal y como observamos en la Figura 41, se detectó la presencia de FLAG-NBS1 en el precipitado de los tres miembros de la familia VRK y no en el precipitado control (GST). Por lo tanto, estos resultados nos indican que los tres miembros estudiados (VRK1 y las dos isoformas de VRK2) son capaces de interaccionar con NBS1.

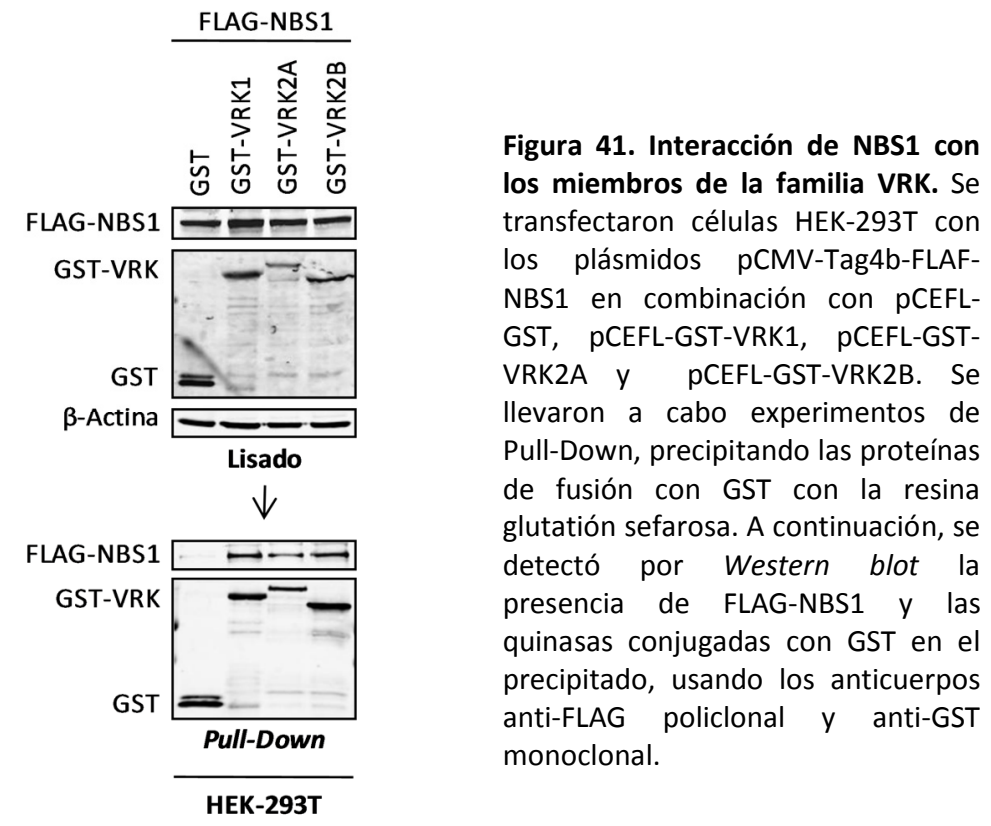


A continuación, quisimos identificar qué regiones de VRK1 podrían estar implicadas en la interacción con NBS1. Puesto que se ha detectado la interacción de NBS1 con VRK1, VRK2A y VRK2B, se esperaría que dicha interacción posiblemente se llevara a cabo en la región amino-terminal, dado a la alta homología de esta región en los tres miembros VRK. Para resolver esta duda, transfectamos células HEK-293T con plásmidos de VRK1 que codifican diferentes regiones de la proteína, pcDNA3.1VRK1-Myc (VRK1 silvestre aa 1-396), pcDNA3.1-VRK1-NL-Myc (VRK1 amino largo aa 1-332), pcDNA3.1-VRK1-NC-Myc (VRK1 amino corto aa 1-267) o pCEFL-GST-VRK1-C (VRK1 carboxilo aa 267-396) en combinación con el plásmido pIRES2-FLAG-NBS1. Se realizó la inmunoprecipitación de FLAG-NBS1 y se detectó la presencia de las construcciones de VRK1 con los anticuerpos anti-Myc o anti-GST según corresponda. Podemos observar como FLAG-NBS1 interacciona con las cuatro construcciones de VRK1 (Figura 42A y B). Por lo tanto, VRK1 interacciona con NBS1 a través de aminoácidos presentes tanto en la región amino como carboxilo terminal, quizás debido a la estructura terciaria de la proteína.

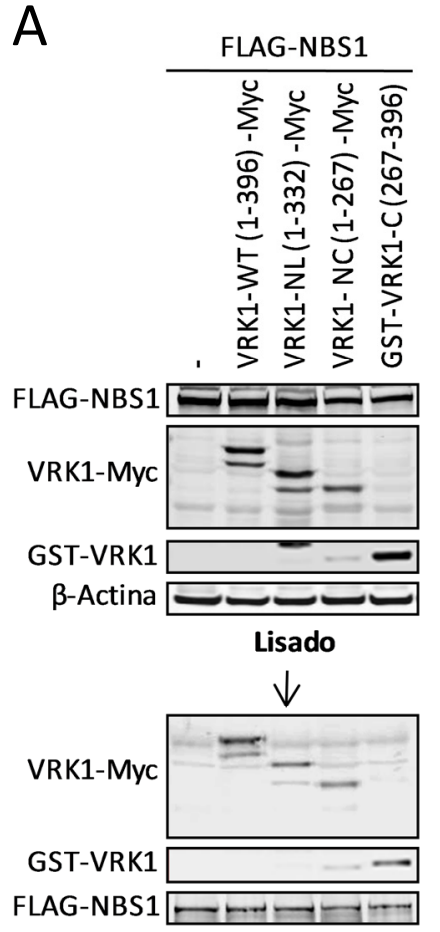

IP FLAG-NBS1

HEK-293T
B

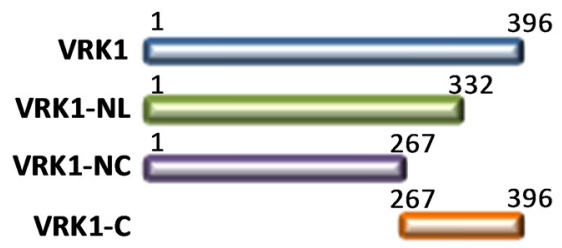

Figura 42. Identificación de la zona de VRK1 que interacciona con NBS1. A. Células HEK-293T fueron transfectadas con los plásmidos pIRES2FLAG-NBS1 en combinación con pCEFL-HA, pcDNA3.1-VRK1-Myc, pcDNA-VRK1-NL (1-332 aa)-Myc, pcDNA3.1-VRK1-NC (1-267 aa)-Myc, pCEFL-GST-VRK1-C (267-396 aa), y 48 horas después, las células fueron lisadas. Los extractos fueron empleados para inmunoprecipitar FLAGNBS1 con un anticuerpo policlonal anti-FLAG. Las diferentes construcciones de VRK1 se detectaron en el lisado y el precipitado con los anticuerpos monoclonales anti-Myc y anti-GST. B. Representación esquemática de las construcciones de VRK1 usadas en la figura A. 
Adicionalmente, se estudió la interacción de NBS1 con la quinasa inactiva VRK1, con el fin de determinar si la interacción de ambas proteínas era dependiente de la actividad quinasa de VRK1. De este modo, células HEK-293T fueron transfectadas con el plásmido pCEFL-GST o pCEFL-GST-VRK1 (K179E) y tratadas con doxorubicina $1 \mu \mathrm{M}$ durante 2 horas o dejadas sin tratar. Se llevó a cabo un ensayo Pull-Down donde se detectó la presencia de NBS1 endógeno. Como podemos observar en la figura 43 la quinasa inactiva VRK1 interacciona con NBS1 independientemente del daño en el ADN. Sin embargo, se observa una leve disminución en la interacción al tratar las células con doxorubicina. Sugiriendo, que la carencia de autofosforilación de VRK1 no es un factor importante para su interacción con NBS1.

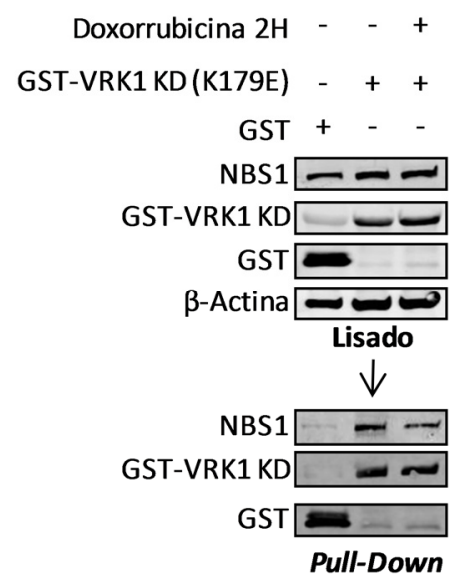

Figura 43. Interacción entre VRK1 K179E (quinasa inactiva) con NBS1. Células HEK-293T fueron transfectadas con la quinasa inactiva pCEFL-GST-VRK1 (K179E) durante 48 horas. Posteriormente, las células fueron tratadas con doxorubicina $1 \mu \mathrm{M}$ durante 2 horas. Se realizó Pull Down de GST-VRK1 (K179E) con la resina glutatión sefarosa. A continuación se detectó por Western blot la presencia de NBS1 endógeno en el precipitado.

\subsubsection{NBS1 es diana de fosforilación de VRK1}

NBS1 es fosforilado en varios residuos de serina y treonina. Entre los más estudiados se encuentran la serina 278 y serina 343, fosforiladas por ATM en respuesta al daño en el ADN (Zhao. 2000). Al conocer que NBS1 tenía varios residuos potenciales de fosforilación, nos planteamos la posibilidad de que esta proteína fuera sustrato de fosforilación de la quinasa VRK1. Por tal motivo, se llevaron a cabo ensayos quinasa in vitro en presencia de $\left(\mathrm{y}^{-32} \mathrm{P}\right)$ ATP, empleando las proteínas purificadas pGEX-GSTVRK1 y pGEX-GST-p53 (aa 1-85) y la proteína FLAG-NBS1 transfectada y precipitada de células eucariotas. En la autorradiografía se detectó la autofosforilación de VRK1, y la fosforilación del sustrato p53 por VRK1 como controles positivos. Además confirmamos como la quinasa humana VRK1 fosforila a NBS1, obteniendo así un nuevo sustrato de dicha quinasa (Figura 44). 


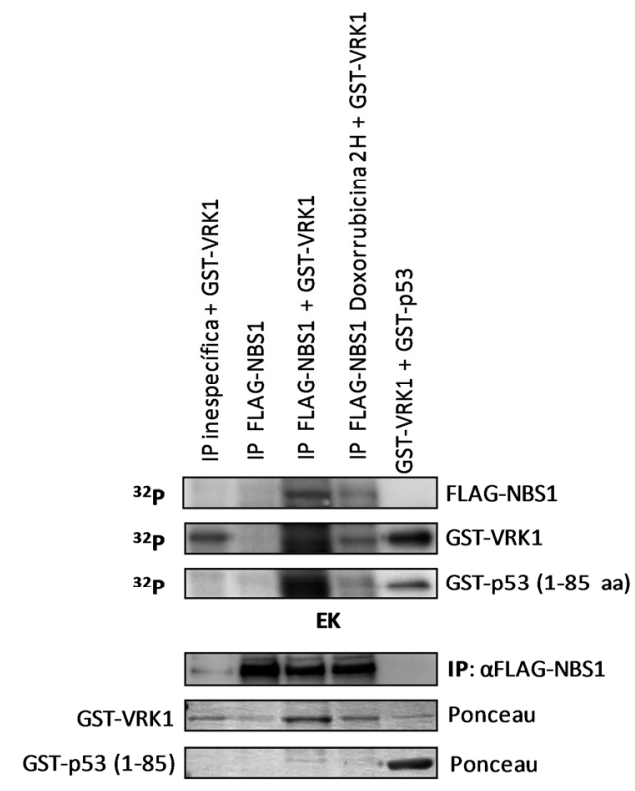

Figura 44. NBS1 es diana de fosforilación de VRK1. Células HEK293T fueron transfectadas con pIRES-FLAG-NBS1 durante 48 horas. Posteriormente, las células fueron tratadas con doxorubicina $1 \mu \mathrm{M}$ durante 2 horas. Se inmunoprecitó FLAG-NBS1 con un anticuerpo policlonal anti-FLAG. Se llevo a cabo ensayo quinasa in vitro en presencia de $\left(\mathrm{y}^{32} \mathrm{P}\right)$ ATP con la proteína purificada GST-VRK1 y FLAG-NBS1 inmunoprecipitada. Como control positivo se añadió un punto utilizando GST-p53 como sustrato conocido de VRK1. Se indica la incorporación de la radiactividad $\operatorname{con}^{32} \mathrm{P}$.

El residuo serina 343 de NBS1 es uno de los principales blancos de ATM, siendo fosforilado después de producirse el daño por radiación ionizante. Esta modificación postraduccional dependiente de ATM, es necesaria para la transducción de señales a proteínas efectoras que se encuentran más abajo en la cascada de señalización como Chk1 y Chk2, controlando la parada del ciclo celular en fase S (Lim et al, 2000). La fosforilación de NBS1 es crítica para la acumulación de proteínas de reparación a las DSBs (Assenmacher \& Hopfner, 2004). Puesto que este residuo es importante para la correcta propagación de la señal, decidimos estudiar si VRK1 como quinasa podría estar regulando los niveles de fosforilación en este residuo. Para ello, silenciamos la expresión de VRK1 con un ARN de interferencia específico (SiVRK1-02) en células A549 y utilizamos como control un ARN (Si-C) que no tiene diana en eucariotas. Transcurridas 96 horas, las células fueron tratadas con radiación ionizante (3 Gy), doxorubicina $(1 \mu \mathrm{M})$ o dejadas sin tratar. Se prepararon extractos celulares para detectar los niveles de fosforilación con anticuerpos fosfoespecíficos de diferentes proteínas mediante Western blot. En la figura 45 A y B se puede observar el incremento de los niveles de fosforilación del residuo serina 343 de NBS1, tras radiación ionizante o tratamiento con doxorubicina en comparación a las células no tratadas. Sin embargo, podemos apreciar que las células A549 con bajos niveles de expresión de VRK1 por efecto del SiVRK1-02, presentan una notable disminución en la fosforilación de la serina 343 de NBS1, mientras que los niveles de NBS1 total se mantienen sin cambios importantes. Adicionalmente, revisamos también la activación de Chk2 mediante la detección de su fosforilación en la treonina 68 con 
un anticuerpo fosfo-específico, como control del efecto de la radiación ionizante y la doxorubicina. La actividad de Chk2 aumenta tras radiación ionizante y doxorubicina, pero no se observa una disminución en su actividad tras silenciar VRK1 (Figura 45 A y B).

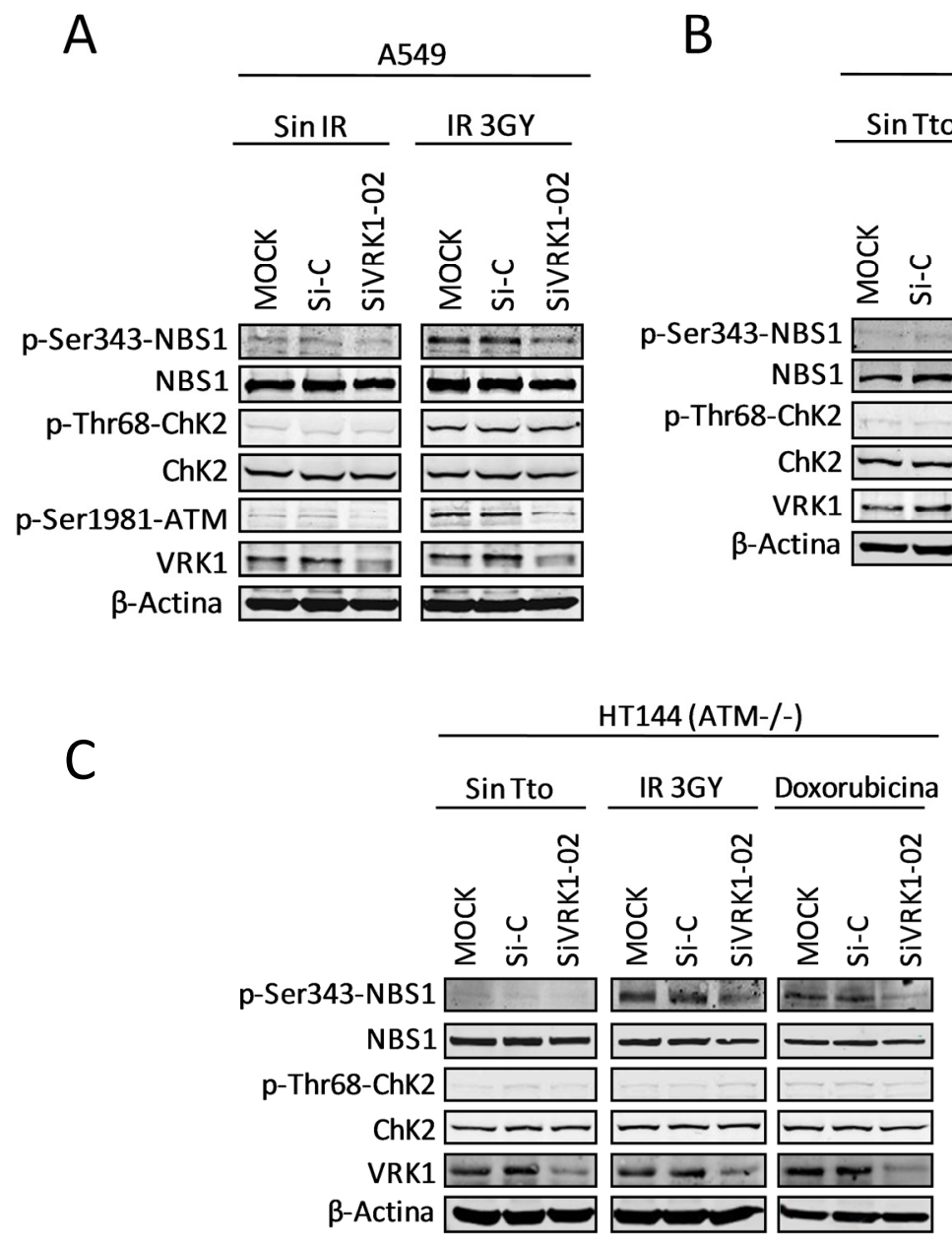

Figura 45. El silenciamiento de VRK1 disminuye los niveles de fosforilación de NBS1 en respuesta a radiación ionizante. Células A549 o HT144 (ATM-/-) fueron transfectadas con ARN control (Si-C), ARN de interferencia específico para VRK1 (SiVRK1-02), o dejadas sin transfectar (MOCK). 96 horas después, A. Las células A549 fueron tratadas con 3 Gy de radiación gamma o dejadas sin tratar ( $\sin$ IR). Las células se dejaron recuperar durante 30 minutos. B. Las células A549 fueron tratadas con doxorubicina $1 \mu \mathrm{M}$ durante 2 horas o dejadas sin tratar (Sin Tto). C. Las células HT144 (deficientes de ATM) fueron tratadas con radiación ionizante ( 3 Gy 30 minutos), doxorubicina (1uM durante 2 horas) o dejadas sin tratar (Sin Tto). Se analizaron por Western blot los niveles de las proteínas totales y fosforiladas en los residuos específicos que se indican en las figuras. Como control de carga se detectó la $\beta$ Actina. 
En el caso de las células A549 irradiadas, estudiamos el grado de activación de ATM mediante la detección de su autofosforilación en el residuo 1981 con un anticuerpo fosfo-específico. Observamos que tras radiación ionizante incrementan los niveles de fosforilación de ATM en este residuo, pero estos niveles disminuyen al silenciar VRK1 (Figura 45A). Por otra parte, teníamos la duda si este efecto de VRK1 sobre los niveles de fosforilación de la serina 343 de NBS1 era independiente de ATM, puesto que, como se ha mencionado anteriormente, ATM fosforila directamente este residuo y podría no ser la única quinasa a considerar. Para comparar el resultado anteriormente obtenido en las células A549 con células deficientes de ATM, se procedió a realizar el ensayo con iguales condiciones experimentales en las células HT144 (ATM-/-). Los niveles de activación de Chk2 no fueron detectados después del estímulo, debido seguramente a la ausencia de ATM. Sin embargo, sí observamos el incremento en la fosforilación de la serina 343 de NBS1 en respuesta al daño producido por la radiación ionizante o el tratamiento con doxorubicina. Esta fosforilación se vio nuevamente afectada en las células con bajos niveles de VRK1, indicándonos así que dicha fosforilación en respuesta al daño en el ADN también es dependiente de la quinasa humana VRK1 (Figura 45C). De este modo concluimos que VRK1 se activa en respuesta a daño mediando la fosforilación de NBS1, importante en el desarrollo de la reparación del ADN, de manera independiente de ATM.

Como hemos demostrado con anterioridad, VRK1 y NBS1 interaccionan de manera independiente del daño en el ADN. Además, conocemos que los niveles de fosforilación de NBS1 son regulados por VRK1. Decidimos así evaluar si la interacción entre NBS1 y VRK1 era anterior a la fosforilación de la serina 343 de NBS1 en respuesta a radiación ionizante. Para ello, inmunoprecipitamos la proteína NBS1 endógena con un anticuerpo policlonal específico, de extracto de células HeLa que expresan altos niveles de VRK1 (HeLa pQCXIP-VRK1) irradiadas con una dosis de 3 Gy o dejadas sin irradiar. En efecto, detectamos la interacción entre NBS1 y VRK1 antes de la fosforilación de NBS1 (Serina 343) producida por radiación ionizante (Figura 46), lo que confirma el resultado de que esta interacción es independiente del daño. 


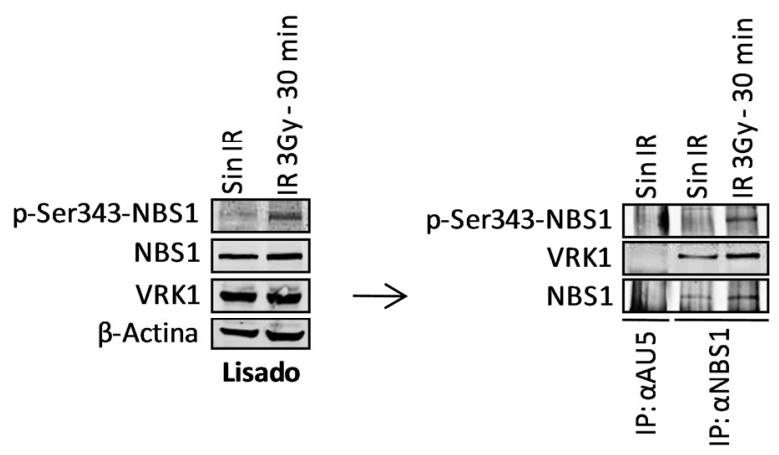

Figura 46. NBS1 y VRK1 están interaccionando antes de la actívacíón de NBS1 tras daño al ADN. NBS1 endógeno fue inmunoprecipitado de células HeLa pQCXIP-VRK1 (expresan altos niveles de VRK1) sin estimular o tras 30 minutos de la irradiación con $3 \mathrm{~Gy}$. Se prepararon los lisados para analizar por Western blot los niveles de fosforilación de la serina 343 de NBS1, NBS1 y VRK1 en los lisados y precipitados, mediante el uso de los anticuerpos anti-fosfo serina 343 de NBS1 policlonal, anti-NBS1 policlonal y anti-VRK1 1 b5 monoclonal.

Dado que ATM puede interaccionar y fosforilar a NBS1, quisimos evaluar si la interacción entre VRK1 y NBS1 desplazaba de alguna manera la interacción con ATM. Así, transfectamos células A549 con los plásmidos pBJ1-HA-ATM, pCMV-Tag4b-FLAGNBS1 y pCEFL-GST-VRK1. Transcurridas 48 horas, las células fueron tratadas con doxorubicina $1 \mu \mathrm{M}$ durante 2 horas o dejadas sin tratar. Se inmunoprecipitó HA-ATM y se detectó la presencia de FLAG-NBS1 y GST-VRK1 en el precipitado. En la figura 47, podemos apreciar como la sobre-expresión de VRK1 no altera la interacción entre ATM y NBS1, es más, parece formarse un complejo proteico entre las tres proteínas independiente del daño producido por la doxorubicina. Observamos también la interacción entre VRK1 y ATM en células que no fueron transfectadas con el plásmido pCMV-Tag4b-FLAG-NBS1.

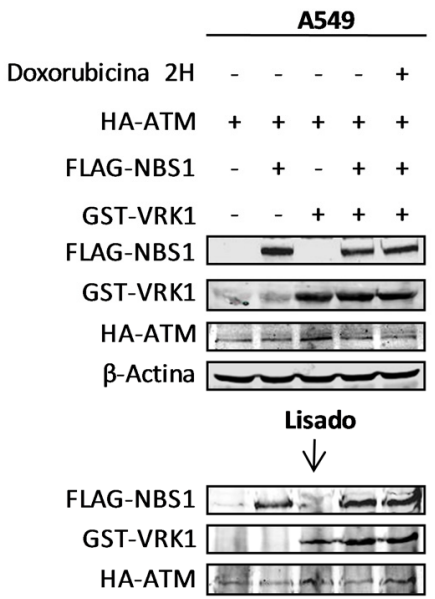

IP HA-ATM
Figura 47. ATM, NBS1 y VRK1 forman un complejo proteico. Células A549 fueron transfectadas con los plásmidos pBJ1-HA-ATM en combinación con pCMV-Tag4b-FLAG-NBS1 y pCEFL-GSTVRK1. Después de 48 las células fueron tratadas con doxorubicina durante 2 horas y posteriormente, fueron lisadas. El extracto celular se utilizó para inmunoprecipitar HA-ATM con un anticuerpo policlonal. En el precipitado se detectó FLAG-NBS1 y GST-VRK1. 
Por otro lado, tras observar que el residuo serina 343 de NBS1 es probablemente regulado por VRK1, decidimos mutar este residuo a alanina (mutante no fosforilable) con el fin de determinar si esta modificación afecta de algún modo la interacción entre ambas proteínas (Figura 48). Igualmente, mutamos el residuo serina 432 de NBS1 a alanina, la fosforilación de este residuo ocurre en las fases S, G2 y M del ciclo celular de manera dependiente de la actividad CDK (Falck et al, 2012).

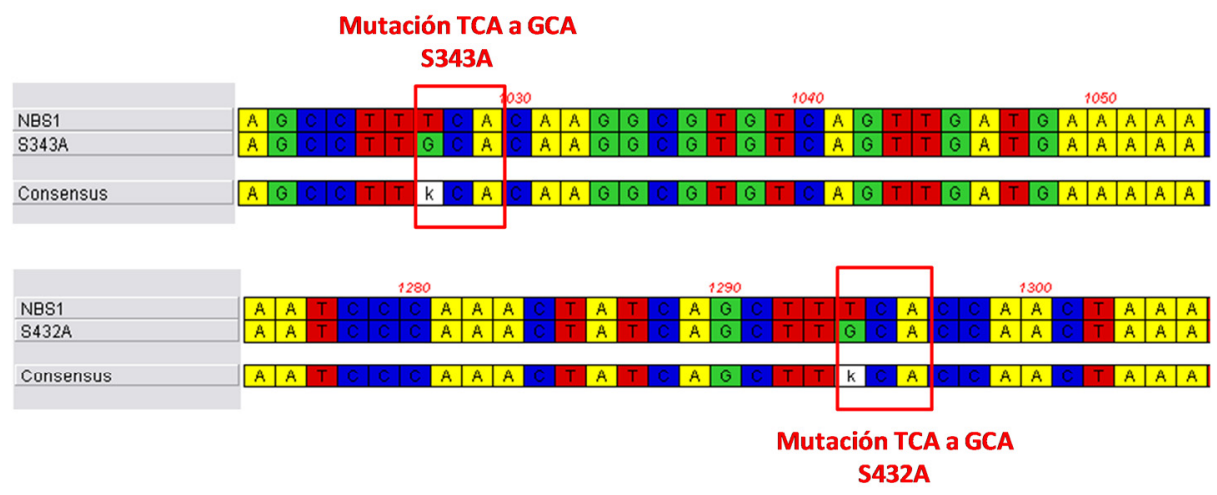

Figura 48. Alineamiento de las secuencias de NBS1 y los mutantes no fosforilables S343A y S432A. Se diseñaron oligonucleótidos específicos para el cambio de la secuencia TCA que codifica para el residuo de serina a GCA que codifica para el residuo de alanina. Se realizó mutagénesis dirigida utilizando el sistema QuickChange Site-Directed Mutagenesis (protocolo y secuencias de los oligonucleótidos en la sección de materiales y métodos)

Estos mutantes no fosforilables (pCMV-Tag4b-FLAG-NBS1 S343A y pCMV-Tag4bFLAG-NBS1 S432A) y la proteína silvestre (pCMV-Tag4b-FLAG-NBS1) de NBS1 junto con la proteína VRK1 silvestre (pCEFL-HA-VRK1) y la proteína truncada de VRK1 (pCEFL-HA-VRK1 R358X) (generada por un codón de terminación en el aminoácido 358 produciendo la carencia de los últimos 38 aminoácidos de la región carboxilo terminal de la quinasa) fueron transfectados en células HEK-293T. Se comprobó la correcta expresión de las proteínas sobre-expresadas en los extractos celulares (Figura 49 arriba). Posteriormente, se procedió a realizar co-inmunoprecipitaciones de las proteínas transfectadas utilizando los anticuerpos anti-HA o anti-FLAG policlonales. Se realizó como control una inmunoprecipitación con un anticuerpo del mismo isotipo pero sin ninguna diana endógena. En ambos casos, se observaron resultados parecidos. La interacción entre el mutante no fosforilable FLAG-NBS1 S432A y la proteína VRK1 o VRK1 R358X fue similar, en comparación a la interacción con la proteína NBS1 silvestre. Sin embargo, el mutante no fosforilable FLAG-NBS1 S343A presenta mayor interacción con las dos VRK utilizadas (Figura 49). Además, la carencia de los últimos 38 aminoácidos de VRK1 no es indispensable para que VRK1 y NBS1 interaccionen. 

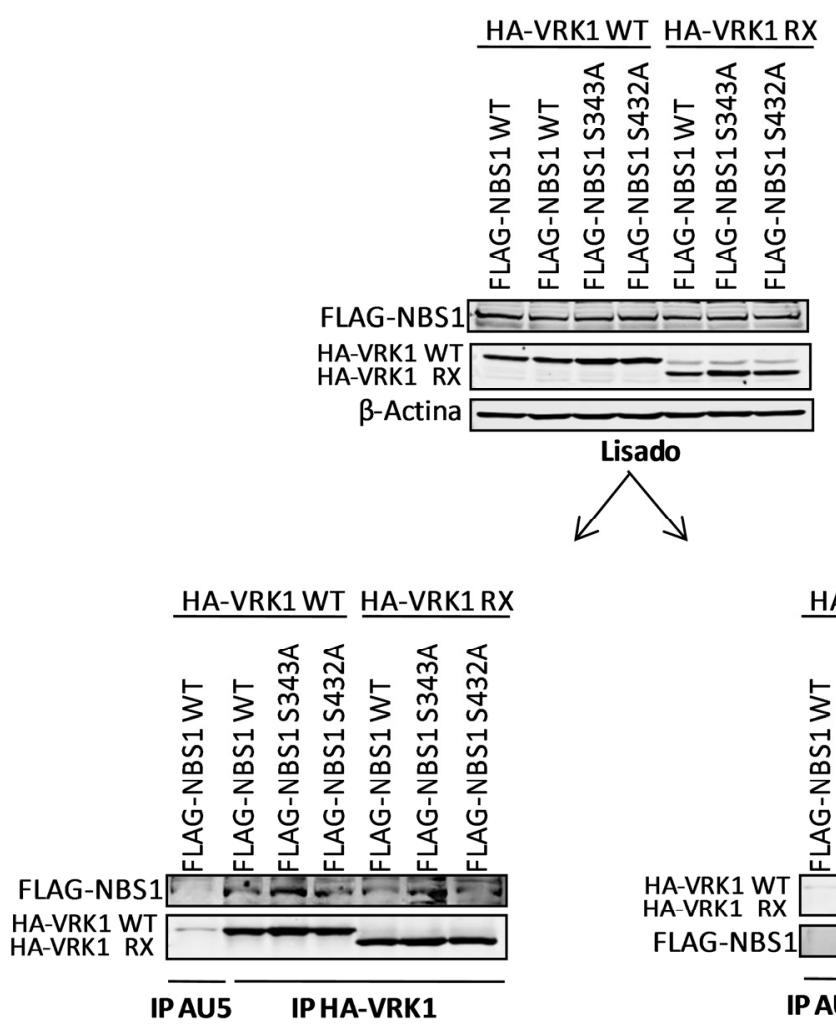

$\underline{\text { HA-VRK1 WT }} \underline{\text { HA-VRK1RX }}$

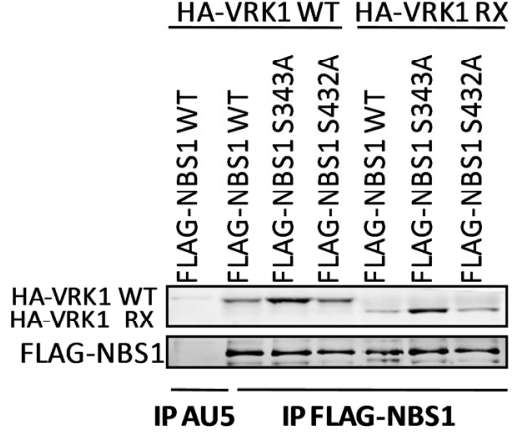

Figura 49. Los mutantes no fosforilables de NBS1 (S343A y S432A) interaccionan con la quinasa VRK1 silvestre y la quinasa VRK1 (R358X). Células HEK-293T fueron transfectadas con los vectores de pCMV-Tag4b-FLAG-NBS1 WT (wild type), pCMV-Tag4b-FLAG-NBS1 S343A (mutante no fosforilable), pCMV-Tag4b-FLAG-NBS1 S432A (mutante no fosforilable) en combinación con pCEFL-HA-VRK1 WT (wild type) y PCEFL-HA-VRK1 R358X. 48 horas después se realizaron inmunoprecipitaciones con el anticuerpo policlonal anti-HA (panel izquierda) o con el anticuerpo policlonal anti-FLAG (panel derecha) con sus respectivas inmunoprecipitaciones inespecíficas usando los anticuerpos anti-AU5 del mismo isotipo.

\subsubsection{VRK1 es necesaria para la correcta formación de los focos de NBS1 en respuesta a radiación ionizante}

Basándonos en los datos obtenidos de la interacción y fosforilación de NBS1 por VRK1, consideramos la posibilidad de que VRK1 tuviera un papel importante en la formación de focos de NBS1 en respuesta a daño. Por este motivo, decidimos analizar el silenciamiento de VRK1 y su efecto sobre el reclutamiento de NBS1 a las DSBs producidas por radiación ionizante. Para ello, células A549 fueron transfectadas con ARN de interferencia específico para VRK1 (SiVRK1-02) y ARN sin 
diana específica como control negativo (Si-C). Transcurridas 96 horas, las células fueron irradiadas con una dosis de $3 \mathrm{~Gy}$ y dejadas recuperar durante 30 minutos.

Puesto que la supresión de la expresión de VRK1 bloquea la progresión del ciclo celular en la fase G1, decidimos analizar la formación de focos de NBS1 tras irradiar células mantenidas en bajos niveles de suero (0.5\% de FBS) durante 48 horas, produciendo el mismo efecto que el silenciamiento de VRK1, con el fin de descartar que la alteración en la formación de los focos de NBS1 fuera un efecto directo de la supresión de VRK1 y no un efecto secundario producido por la parada del ciclo celular. Como se observa en la figura 50A (pág. siguiente, pie de figura en pág. 125), no hay cambios en la localización de NBS1 tras irradiar las células mantenidas en $0.5 \%$ de FBS en comparación a las células asincrónicas (MOCK). Por ende, concluimos que la parada del ciclo producida por la deficiencia de VRK1 no afecta la formación de focos de NBS1 en respuesta al daño en el ADN producido por radiación ionizante. Por otro lado, observamos la acumulación de NBS1 en los sitios donde se ha producido el daño en células no transfectadas (MOCK), así como en células transfectadas con $\mathrm{Si}-\mathrm{C}$ después de ser irradiadas, en comparación con las células sin irradiar. Sin embargo, en las células con baja expresión de VRK1 (controles en la figura 50B, pág. siguiente, pie de figura en pág. 125), se observó una clara deficiencia en la localización de NBS1 en los focos inducidos por radiación ionizante (Figura 50A). Posteriormente, procedimos a la cuantificación de los focos de NBS1, pero este procedimiento no se pudo realizar debido a que estos eran abundantes y no estaban bien definidos. Por lo tanto, decidimos cuantificar los niveles de fluorescencia en el programa ImageJ; mostrados en la figura 50C (pág. siguiente, pie de figura en pág. 125) en la cual se observa la reducción de los niveles de fluorescencia de NBS1 en las células silenciadas con SiVRK1-02. Dados estos resultados afirmamos que la quinasa VRK1 es esencial para el correcto reclutamiento de NBS1 a los sitios de lesión después del daño al ADN.

A continuación, con el fin de verificar el resultado anteriormente obtenido, decidimos utilizar otro ARN de interferencia para silenciar VRK1. Para ello, transfectamos células A549 con los ARN de interferencia SiVRK1-02, SiVRK1-03 y SiC. En las mismas condiciones que el experimento descrito anteriormente, se procedió a analizar la formación de focos de NBS1 tras irradiar las células con una dosis de 3 Gy. En la figura 50D (pág. 125) confirmamos que el silenciamiento de VRK1 (con cualquiera de los ARNs de interferencia utilizados) (Figura 50E, pág. 125) afecta al reclutamiento de NBS1 a los puntos de rotura del ADN. 


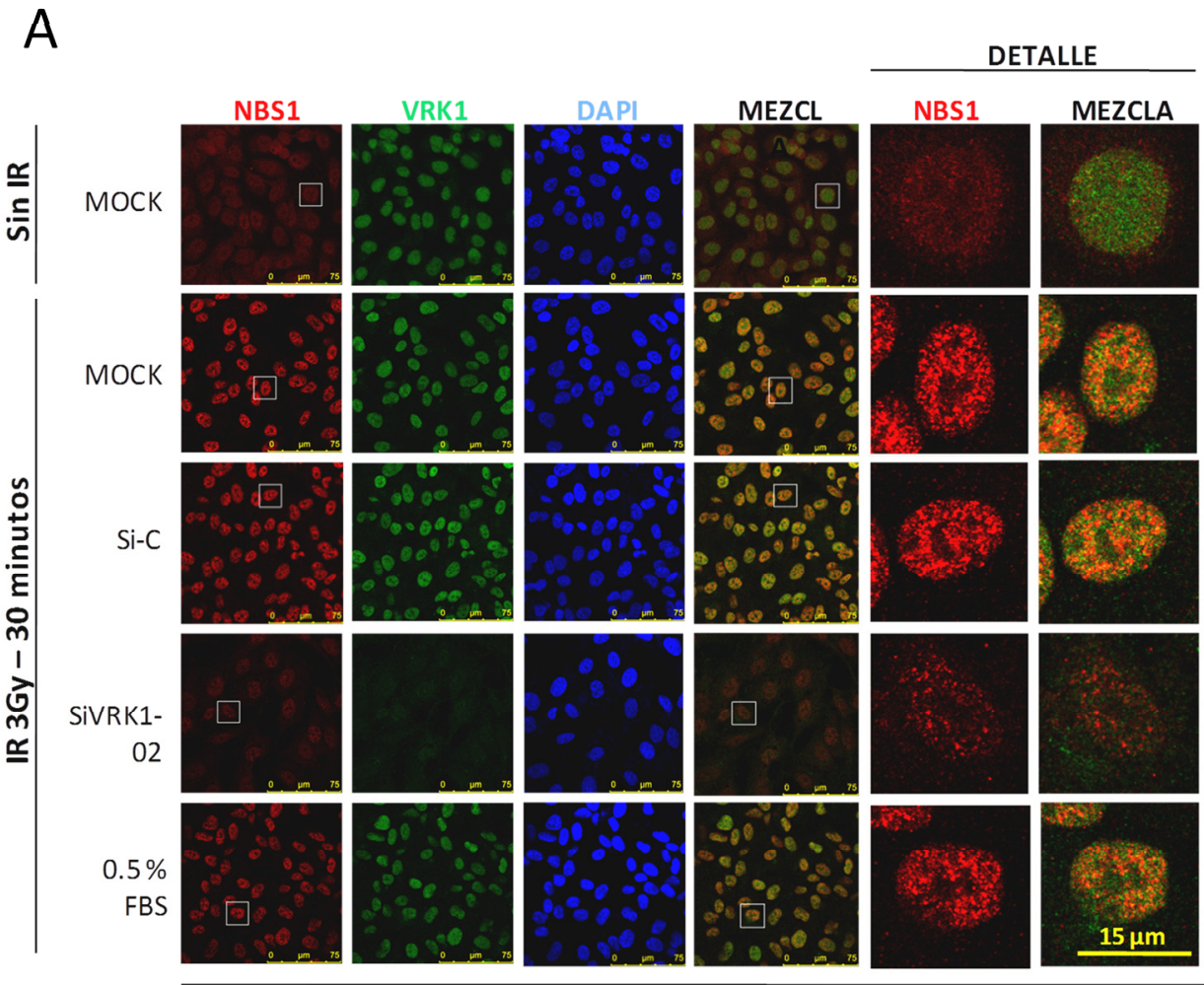

B

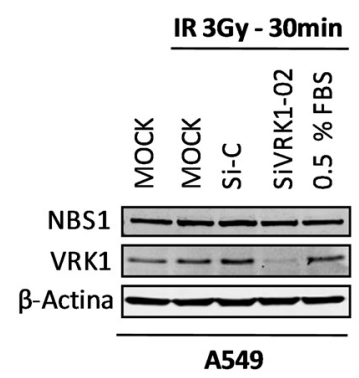

C

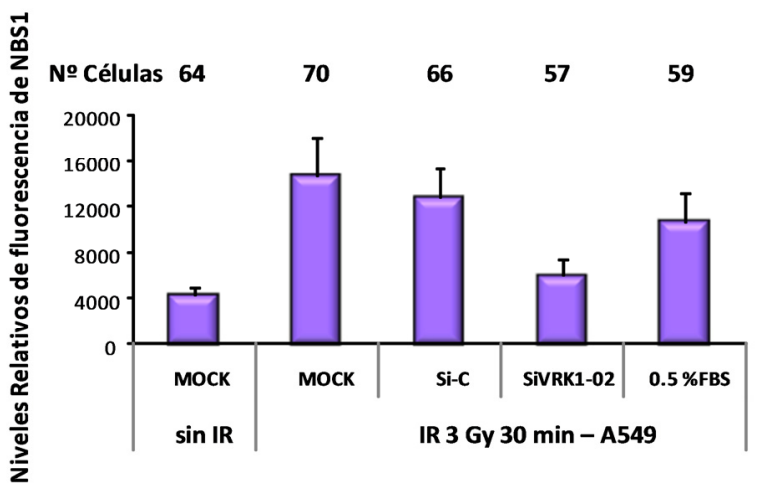




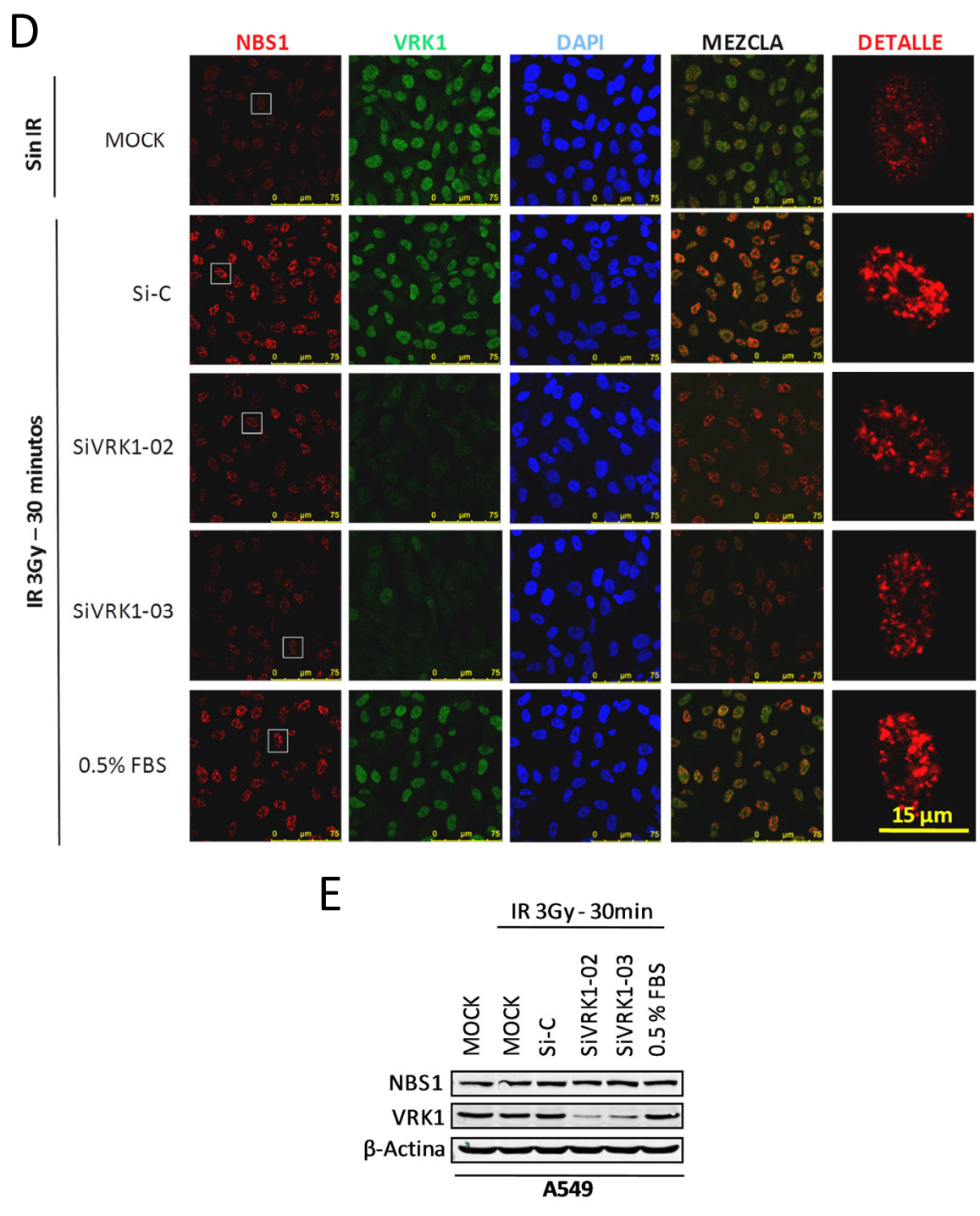

Figura 50. El silenciamiento de VRK1 afecta la formación de focos de NBS1 en respuesta a radiación ionizante. A. Detección de NBS1 en células A549 tratadas o no con radiación ionizante (3 Gy - recuperación 30 minutos) después de la transfección con los ARN de interferencia Si-C y SiVRK1-02 o dejadas sin transfectar (MOCK) o mantenidas 48 horas con $0.5 \%$ FBS. En la inmunofluorescencia se utilizaron los anticuerpos anti-NBS1 monoclonal (rojo) y anti-VRK1 policlonal (verde), los núcleos se tiñeron con DAPI (Azul). A la derecha de la figura se muestra en detalle la localización de NBS1 y VRK1 en una célula, así como el solapamiento de ambas proteínas. La barra indica $15 \mu \mathrm{m}$. B. Análisis por Western Blot de la expresión de VRK1 en las células A549 empleadas en la figura A. C. Representación gráfica de los niveles relativos de fluorescencia de NBS1 por cada punto de la figura A. Se indica en la parte superior el número de células usadas para realizar la cuantificación en el programa ImageJ, con el cual se obtuvo el promedio de emisión de fluorescencia. Se representan las medias y desviaciones estándar. D. Confirmación del efecto del silenciamiento de VRK1 sobre los focos de NBS1, se usaron iguales condiciones que en la figura A. Sin embargo, las células A549 fueron transfectadas con un ARN de interferencia para VRK1 adicional (SiVRK1-03). E. La expresión de proteínas de la figura D se analizó por Western blot. 


\subsubsection{El efecto de VRK1 sobre los focos de NBS1 es independiente de ATM}

La reparación de las DSBs es llevada a cabo principalmente por la activación de la ruta de señalización de ATM, sin embargo, no se descarta la posibilidad de que otras quinasas participen activamente en este proceso. Por esta razón, nos preguntábamos si VRK1 tendría un efecto similar en la formación de focos de NBS1 pero en células deficientes en ATM. Para resolver esta duda, silenciamos VRK1 con un ARN de interferencia específico en la línea celular HT144 (ATM-/-) y analizamos su efecto en la formación de focos de NBS1 tras irradiar con 3 Gy. Se observó la formación de focos de NBS1 tras irradiar independientemente de la presencia de ATM. Sin embargo, si se comparan estos focos de NBS1 con los formados en células con presencia de ATM como las A549, vemos que la morfología de estos focos es más difusa y el número de focos es menor. En las células HT144 que presentaban bajos niveles de VRK1 por el efecto del ARN de interferencia, se observó una drástica reducción en el reclutamiento de NBS1 en los puntos de lesión del ADN en comparación a las células con ARN control o células sin transfectar (MOCK) (Figura 51A). Cuantificamos además los niveles de fluorescencia de NBS1 para apoyar el resultado anterior (Figura 51B). Este resultado nos confirma que la función de VRK1 en el correcto ensamblaje de focos de NBS1 es independiente de ATM, además de situar a VRK1 en la cúspide de la respuesta al daño en el ADN, junto a ATM.

Figura 51. El silenciamiento de VRK1 afecta la formación de focos de NBS1 en células deficientes de ATM. A. Células HT144 (ATM-/-) fueron transfectadas con ARN control y ARN de interferencia específico para VRK1 (SiVRK1-02), dejadas sin transfectar (MOCK) 0 mantenidas durante 48 horas con 0\% FBS. 96 horas después las células fueron irradiadas con 3 Gy o dejadas sin irradiadar. Transcurrido el tiempo de recuperación tras la IR (30 min) las células fueron fijadas y procesadas para inmunofluorescencia. Se detectó NBS1 en rojo con un anticuerpo monoclonal y VRK1 en verde con un anticuerpo policlonal, los núcleos fueron teñidos con DAPI (azul). La barra indica $10 \mu \mathrm{m}$. En la parte derecha se muestra una ampliación de las células señaladas en el recuadro. B. Cuantificación de los niveles de fluorescencia de NBS1 de las células de la figura A con el programa ImageJ. En la parte superior se indica la cantidad de células usadas para la cuantificación. 


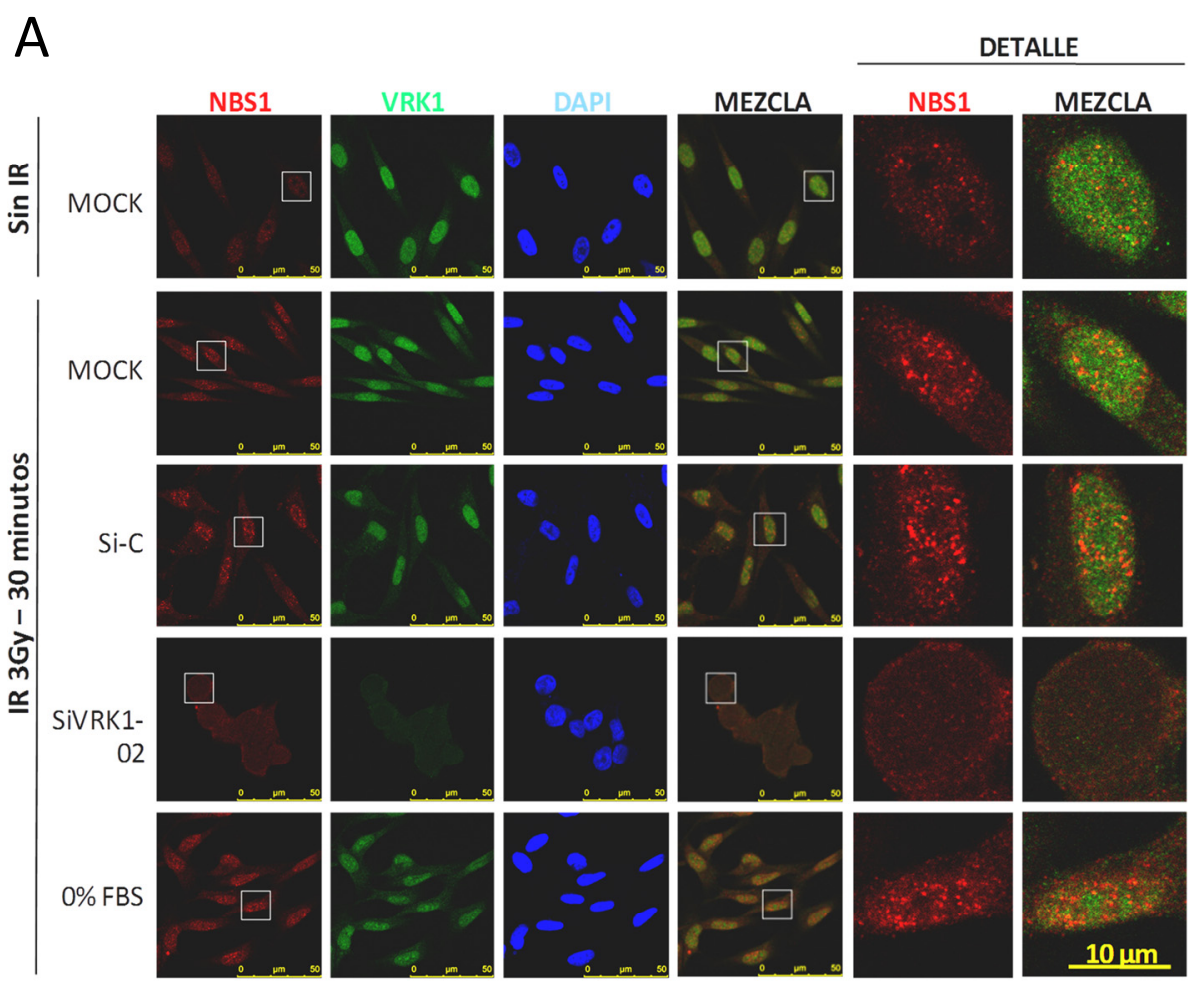

Línea celular HT144 (ATM-/-)

B

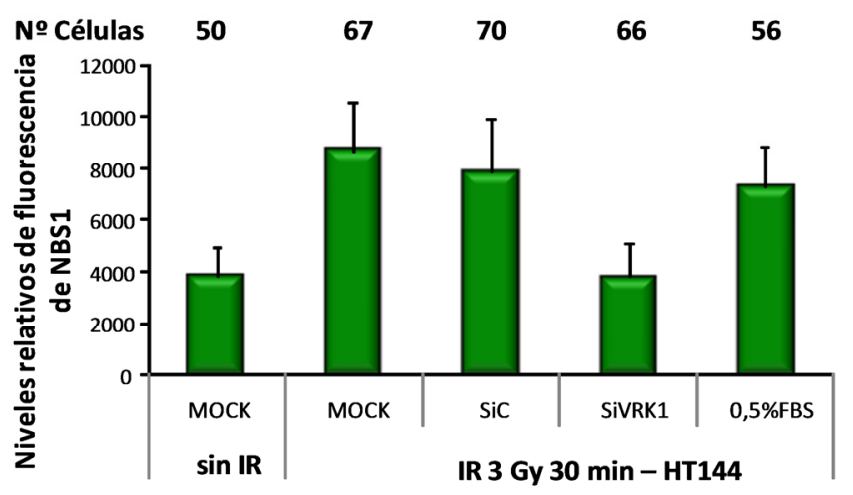

\subsubsection{VRK1 y ATM son necesarias para mantener los niveles proteicos de NBS1}

Hemos demostrado con anterioridad que VRK1 es necesaria para el correcto ensamblaje de focos de NBS1 de manera independiente de ATM. Casualmente al realizar los controles en Western blot de los niveles totales de la proteína NBS1 en 
células deficientes de ATM, vimos una disminución en dichos niveles en las células con baja expresión de VRK1. Quisimos corroborar si en realidad VRK1 afectaba los niveles proteicos de NBS1 en células deficientes de ATM o sólo era un error experimental.

A

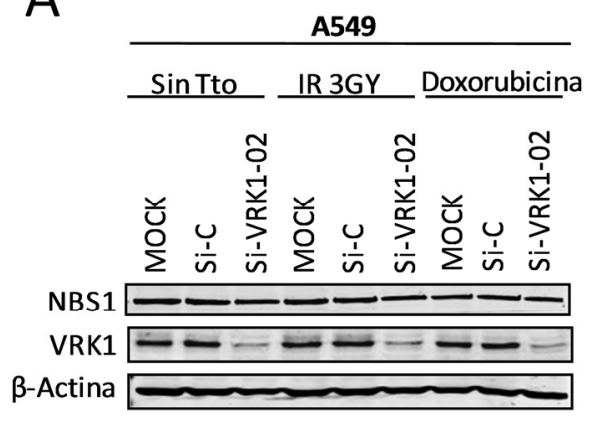

B
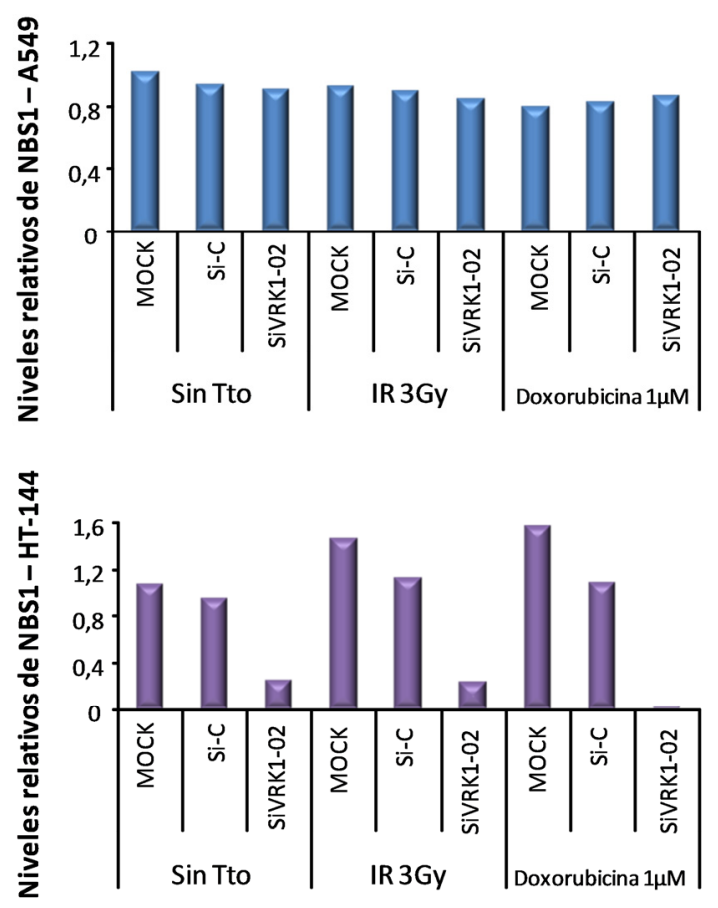

HT144 (ATM-/-)

SinTto IR $3 G Y$ Doxorubicina

NBS1

VRK1

B-Actina

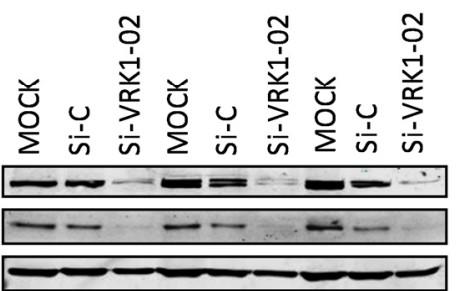

C

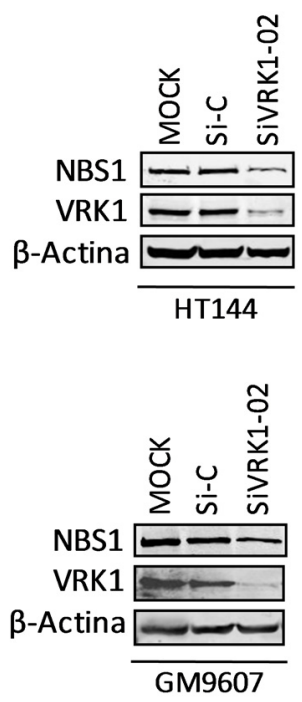


Figura 52. El silenciamiento de VRK1 en células deficientes de ATM afecta la expresión de NBS1. A. Células A549 o HT144 (ATM-/-) fueron transfectadas con ARN control o RNA de interferencia específico para VRK1 (SiVRK1-02) o dejadas sin transfectar (MOCK). 72 horas después las células fueron tratadas con doxorubicina ( $1 \mu \mathrm{M}$ durante 2 horas), irradiadas a $3 \mathrm{~Gy}$ (30 minutos de recuperación) o dejadas sin tratar (Sin Tto). Se analizaron por Western blot los niveles de expresión de NBS1 y VRK1 endógenos con anticuerpos específicos. Como control de carga se detectó a la $\beta$-Actina. B. Cuantificación de los niveles de expresión de NBS1 correspondientes a la gráfica A utilizando el programa Quantity One de BIORAD. C. Silenciamiento de VRK1 en las líneas celulares deficientes de ATM HT144 y GM9607. 96 horas después de la transfección con Si-C o SiVRK1-02, se recogieron los extractos y a continuación se analizaron los niveles de NBS1 y VRK1 por Western blot.

Para ello, silenciamos la expresión de VRK1 en células A549 (utilizadas como control) y células HT144 (ATM-/-). Además, tal y como se indica en la figura 52, después de 72 horas de transfección con los ARNs de interferencia, las células fueron tratadas con IR, doxorubicina o dejadas sin tratar. Posteriormente, detectamos los niveles de NBS1 y VRK1 por Western blot. En las células A549 no observamos cambios en los niveles proteicos de NBS1 en ninguna de las condiciones anteriormente descritas (Figura 52A izquierda y B superior). Sin embargo, si observamos una drástica disminución de los niveles de expresión de NBS1 al silenciar VRK1 en las células deficientes de ATM (Figura 52A derecha y B inferior) siendo esta disminución independiente del daño producido (Figura 52C).

A la vista de estos resultados, quisimos determinar si la alteración en los niveles de NBS1 era efecto directo de la falta de actividad de ATM sumado a la deficiencia de VRK1. Para ello, transfectamos células A549 con los ARN de interferencia control y uno específico para VRK1 o dejadas sin transfectar. Después de 72 horas, las células fueron tratadas con $10 \mu \mathrm{M}$ de KU55933 (inhibidor potente y selectivo de ATM) y 10 mM de cafeína (inhibidor no selectivo de ATM) durante 1 hora. Posteriormente, se provocó daño en el ADN mediante tratamiento con doxorubicina $3 \mu \mathrm{M}$ durante $1 \mathrm{H}$, con el fin de activar las proteínas que participan en la reparación del ADN. En la figura 53 observamos que no hay cambios en los niveles de expresión de NBS1 tras el silenciamiento de la expresión de VRK1 y el tratamiento con los inhibidores de ATM. Sin embargo, utilizamos como control los niveles de fosforilación del residuo treonina 68 de Chk2 (sustrato directo de ATM), el cual incrementa tras el estímulo con doxorubicina y disminuye en los puntos con el tratamiento de los inhibidores de ATM. Por lo tanto, concluimos que es necesaria la presencia de las quinasas ATM y VRK1 para mantener los niveles de expresión de NBS1. 


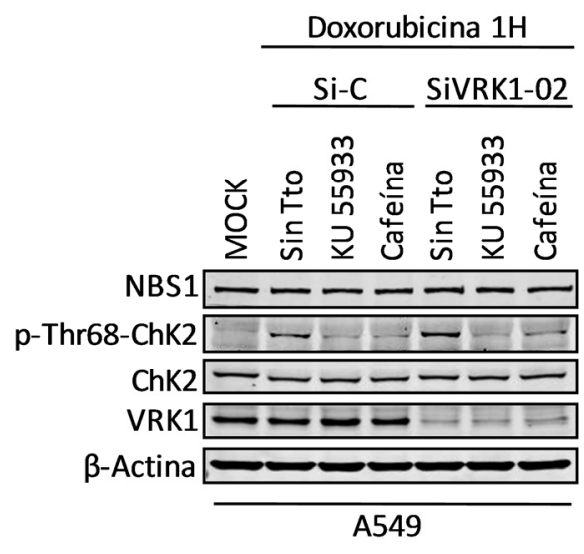

Figura 53. La inhibición de la actividad de ATM y el silenciamiento de VRK1 no altera los niveles de expresión de NBS1 en células A549. Transcurridas 96 horas de transfección con los ARN de interferencia Si-C y SiVRK1-02, las células A549 fueron tratadas con los inhibidores de ATM cafeína (inhibidor no selectivo) y KU55933 (inhibidor potente y selectivo) a $10 \mathrm{mM}$ y 10 $\mu \mathrm{M}$, respectivamente, durante 1 hora. A continuación las células fueron tratadas con doxorubicina $3 \mu \mathrm{M}$ durante 1 hora. En los extractos celulares se analizaron los niveles de NBS1 y VRK1 con los anticuerpos policlonales anti-NBS1 y anti-VRK1 VC por Western blot. Se detectaron los niveles de fosforilación en el residuo treonina 68 de Chk2 como control de la efectividad de los inhibidores de ATM, así como la cantidad de proteína total de Chk2 con anticuerpos específicos.

En base a estos resultados, quisimos analizar la estabilidad proteica de NBS1 y VRK1 en las células deficientes de ATM. Para ello, células A549 y HT144 fueron tratadas con $50 \mu \mathrm{g} / \mathrm{mL}$ de cicloheximida (inhibidor de la síntesis proteíca en eucariotas) a diferentes tiempos. Como se observa en la figura 54A, NBS1 y VRK1 son proteínas estables independientemente de la línea celular estudiada, manteniéndose los niveles de ambas proteínas después de 10 horas de inhibición de la síntesis proteica. Adicionalmente, estudiamos la estabilidad de NBS1 en células deficientes de ATM silenciando la quinasa VRK1, por lo que transfectamos las líneas celulares A549 y HT144 con ARN de interferencia control y ARN de interferencia específico para VRK1. Transcurridas 72 horas, las células fueron tratadas con cicloheximida a diferentes tiempos. En las células A549 no se observaron cambios en los niveles de expresión de NBS1 entre las células silenciadas con siVRK1-02 o células con ARN control, tratadas con cicloheximida (Figura 54B, superior). Por el contario, las células HT144 deficientes de ATM y con bajos niveles de expresión de VRK1, presentaron una leve disminución de los niveles de NBS1 después de las 8 horas de tratamiento con cicloheximida (Figura 54B, inferior), confirmando la menor estabilidad de la proteína NBS1 en ausencia de ATM y VRK1. 

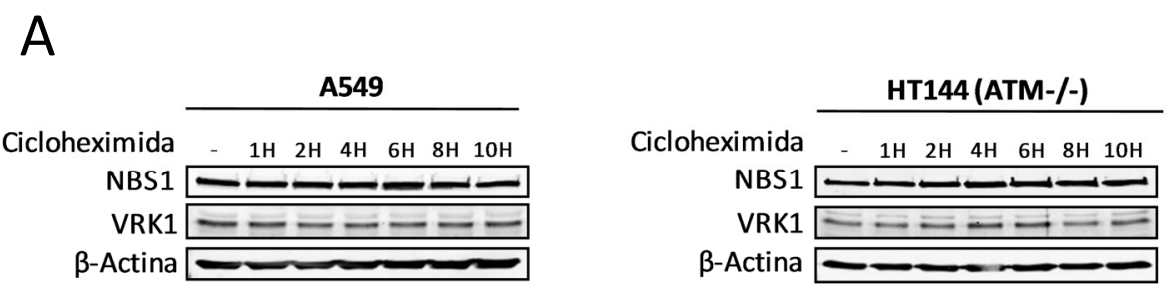

B
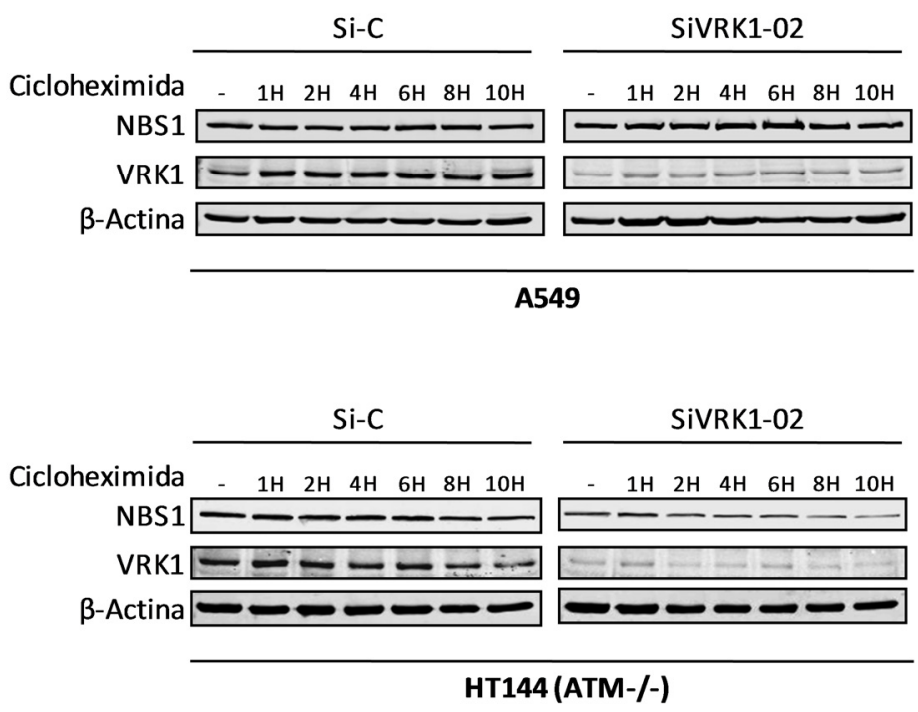

Figura 54. Estabilidad proteica de NBS1 y VRK1 en células A549 y HT144. A. Células A549 y HT144 (ATM-/-) fueron tratadas con $50 \mu \mathrm{g} / \mathrm{ml}$ de cicloheximida (inhibidor de la síntesis proteica) durante diferentes tiempos. Se detectaron los niveles de proteína de NBS1 y VRK1 con los anticuerpos policlonales anti-NBS1 y anti-VRK1 VC, respectivamente, por Western blot. B. 72 horas después de la transfección de las células A549 y HT144 con los ARN de interferencia Si-C y SiVRK1-02, las células fueron tratadas con cicloheximida $50 \mu \mathrm{g} / \mathrm{ml} \mathrm{a}$ diferentes tiempos. Se analizaron por Western blot los niveles de NBS1 con el anticuerpo policlonal anti-NBS1 y VRK1 con el anticuerpo policlonal VC. Se detectaron los niveles de $\beta$ Actina como control de carga.

\subsubsection{VRK1 no interviene en la expresión génica de NBS1}

A la vista de los resultados anteriores, nos planteamos si la disminución de los niveles proteicos de NBS1 era consecuencia de dos posibles alternativas; la regulación de VRK1 sobre la expresión génica de NBS1 o un efecto sobre su degradación proteica. En primer lugar, realizamos ensayos de RT-PCR cuantitativa 
para determinar los niveles de ARNm de NBS1 en células con bajos niveles de expresión de VRK1. Para ello, células A549 y HT144 fueron transfectadas con oligonucleótidos de interferencia específicos para VRK1 (siVRK1-02 y siVRK1-03) o ARN control (Si-C). Después de 96 horas, se realizó la extracción del ARN total. En la figura 55 se representan gráficamente los niveles de ARNm de NBS1 y VRK1. En las dos líneas celulares estudiadas, los oligonucleótidos siVRK1 disminuyeron los niveles de ARNm de VRK1 de manera eficiente. Por otro lado, no se observaron cambios representativos en los niveles de ARNm de NBS1 en células A549 ni HT144 (ATM-/-) tras el silenciamiento de la expresión de VRK1. Por lo tanto, concluimos que NBS1 no es regulado transcripcionalmente por VRK1.

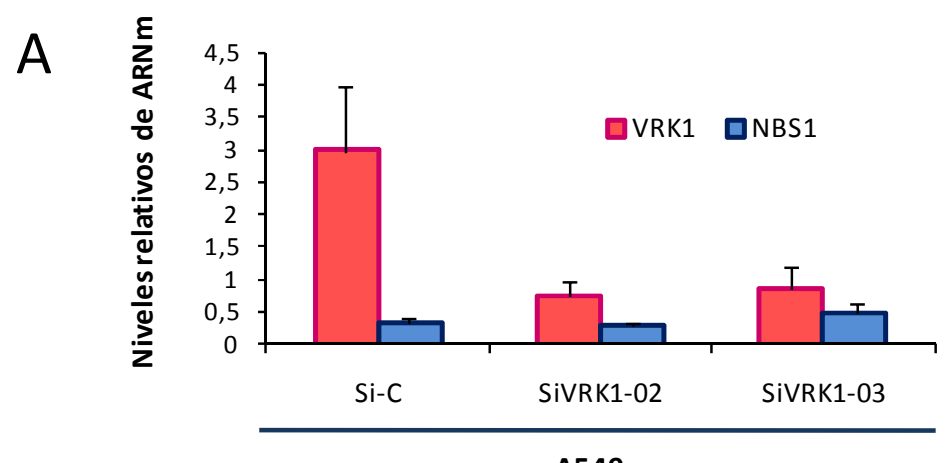

A549

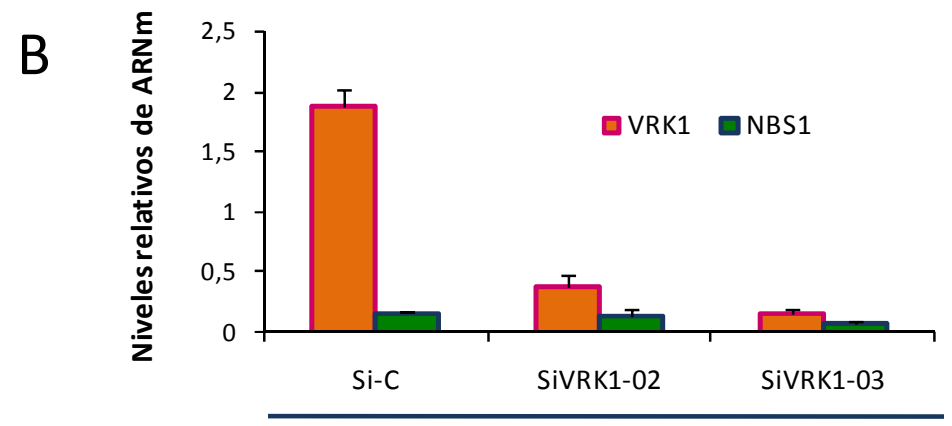

HT144 (ATM-/-)

Figura 55. El silenciamiento de VRK1 no afecta la expresión génica de NBS1. Representación gráfica de los niveles de ARN mensajero de NBS1 y VRK1 en células A549 (A) o HT144 (B) transfectadas durante 96 horas con los ARN de interferencia control (Si-C) o ARN de interferencia específico para VRK1 (siVRK1-02 o siVRK1-03). Se extrajo el ARN total con el kit "RNeasy extraction kit" de Qiagen. Los niveles de ARN mensajero se detectaron mediante RTPCR cuantitativa con oligonucleótidos específicos para NBS1 y VRK1 y se normalizaron con respecto a los obtenidos para la proteína GADPH. 


\subsubsection{VRK1 protege a NBS1 de la degradación por el proteasoma}

Después de descartar la posibilidad que VRK1 regulara la expresión génica de NBS1, decidimos considerar la segunda alternativa sobre la posible degradación proteica de NBS1 como efecto del silenciamiento de VRK1 en células deficientes de ATM. Basados en que proteínas que participan en la reparación de las DSBs pueden ser degradadas en el proteasoma (Ramadan \& Meerang, 2011), quisimos probar si los niveles de NBS1 en células ATM -/- silenciadas con el ARN de interferencia Si-VRK1 eran recuperados al tratar las células con el inhibidor del proteasoma MG132. Para ello, llevamos a cabo experimentos silenciando la expresión de VRK1 con un ARN de interferencia específico (SiVRK1-02) en la línea celular HT144. Utilizamos como controles células transfectadas con Si-Control o células sin transfectar. Después de 48 horas, las células fueron tratadas con $20 \mu \mathrm{M}$ de MG132 a diferentes tiempos. Se detectaron los niveles proteicos de NBS1 y VRK1 por Western blot. En la figura 56 podemos observar que los niveles proteicos de NBS1 disminuyen en células silenciadas con el Si-VRK1. Sin embargo, vemos que estos niveles proteicos se recuperan en las células que han sido tratadas con el inhibidor del proteasoma. Este resultado nos indica que VRK1 protege a NBS1 de la degradación por el proteasoma.

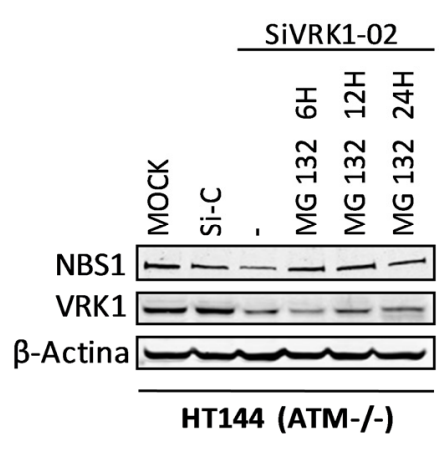

Figura 56. Efecto del inhibidor del proteasoma MG132 sobre los niveles de NBS1 en células HT144 (ATM-/-) silenciadas para VRK1. A. Células HT144 (ATM-/-) fueron transfectadas con los ARN de interferencia Si-C y SiVRK1-02. 96 horas después las células fueron tratadas con el inhibidor del proteasoma MG132 (20 $\mathrm{MM})$ durante 6, $12 \mathrm{y}$ 24 horas. Se detectaron los niveles de NBS1 y VRK1 por Western blot mediante el uso de los anticuerpos policlonales anti-NBS1 y anti-VRK1 VC. Se detectó la $\beta$-Actina como control de carga.

Para verificar el anterior resultado, llevamos a cabo ensayos de inmunofluorescencia empleando las dos líneas celulares deficientes de ATM (HT144 y GM9607), nos planteamos si podríamos revertir el efecto del silenciamiento de VRK1 sobre la formación de focos de NBS1 al inhibir la actividad del proteasoma. Para ello, transfectamos células HT144 y GM9607 con los ARN de interferencia control (Si-C) y específico para VRK1 (Si-VRK1) o dejadas sin transfectar (MOCK). 96 horas después, las células fueron tratadas con $50 \mu \mathrm{M}$ del inhibidor del proteasoma MG132 durante 
6 horas. Posteriormente las células fueron estimuladas con 3 Gy de radiación ionizante y fijadas a los 30 minutos. En ambas líneas celulares, se observó la formación de focos de NBS1 en células no transfectadas o transfectadas con Si-C tras la IR. Sin embargo,las células deficientes de VRK1 presentaron una fuerte disminución en la formación de focos de NBS1. Pero, este efecto fue revertido en las células tratadas con MG132 (Figura 57 B y C, pág. 135 y 136, respectivamente). Por lo que podemos concluir que al parecer VRK1 evita la degradación de NBS1, ayudando a la formación de focos tras radiación ionizante para una correcta reparación del ADN.

Figura 57 A y B. El efecto del silenciamiento de VRK1 sobre los focos de NBS1 se revierte con el inhibidor del proteasoma MG132. Células HT144 (A) o GM9607 (B) fueron transfectadas con los ARN de interferencia Si-C o SiVRK1-02. 96 horas después, las células fueron tratadas con el inhibidor del proteasoma MG132 $(50 \mu \mathrm{M})$ durante 6 horas. A continuación las células fueron irradiadas con 3 Gy de radiación gamma (recuperación 30 minutos) o dejadas sin irradiar. Posteriormente, se detectó por inmunofluorescencia NBS1 con el anticuerpo monoclonal anti-NBS1 (rojo) y VRK1 con el anticuerpo policlonal anti-VRK1 amino de SIGMA (verde). Los núcleos fueron teñidos con DAPI. A la derecha se muestra una ampliación de las células señaladas en el recuadro blanco. La barra indica $10 \mu \mathrm{m}$. En la parte inferior de cada figura de inmunofluorescencia se representa gráficamentee la cuantificación de los niveles de fluorescencia de las células HT144 (A) o GM9607 (B) utilizando el programa ImageJ. En la parte inferior se indica el número de células usadas en la cuantificación. 


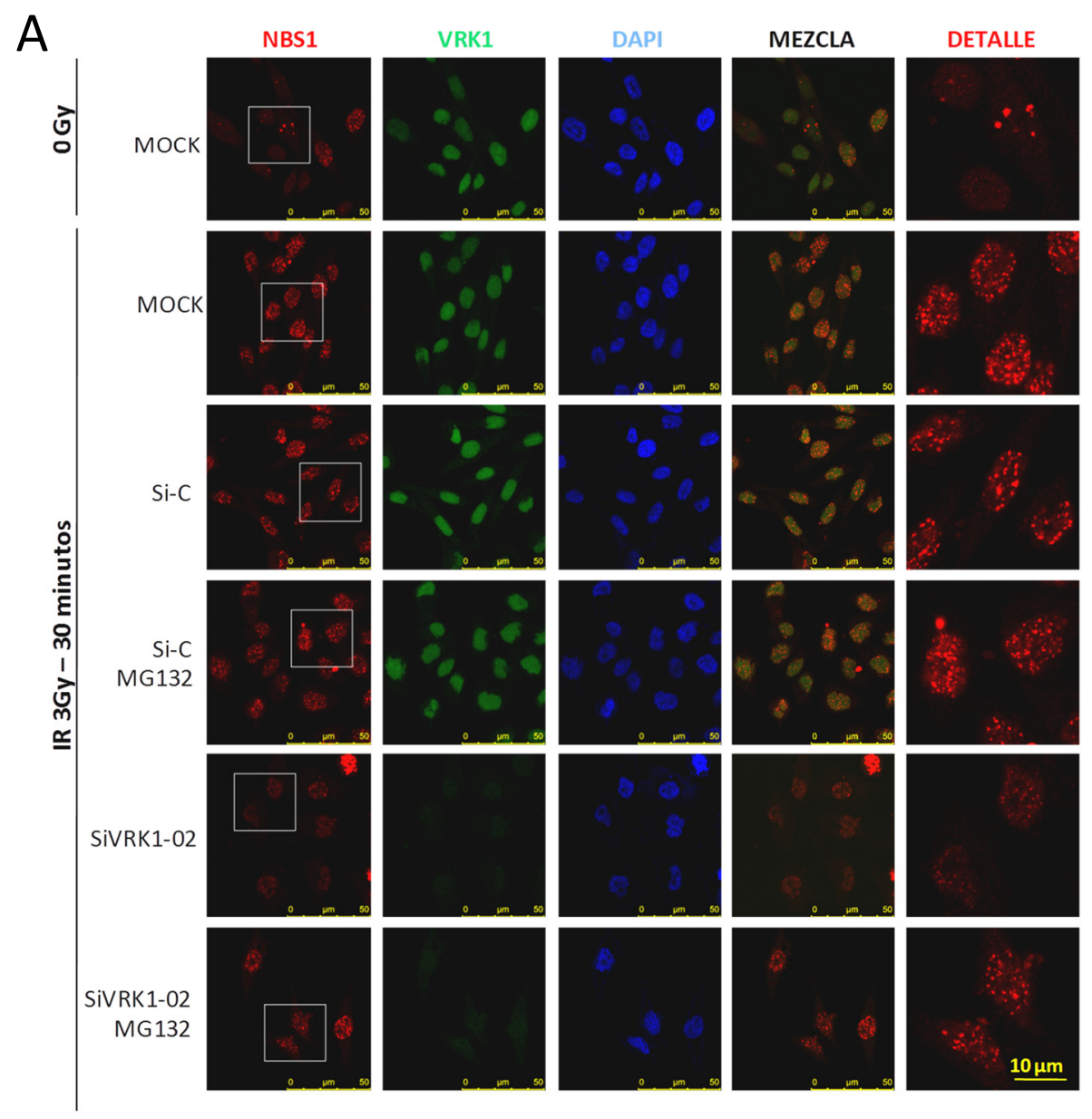

Línea celular HT144 (ATM-/-)

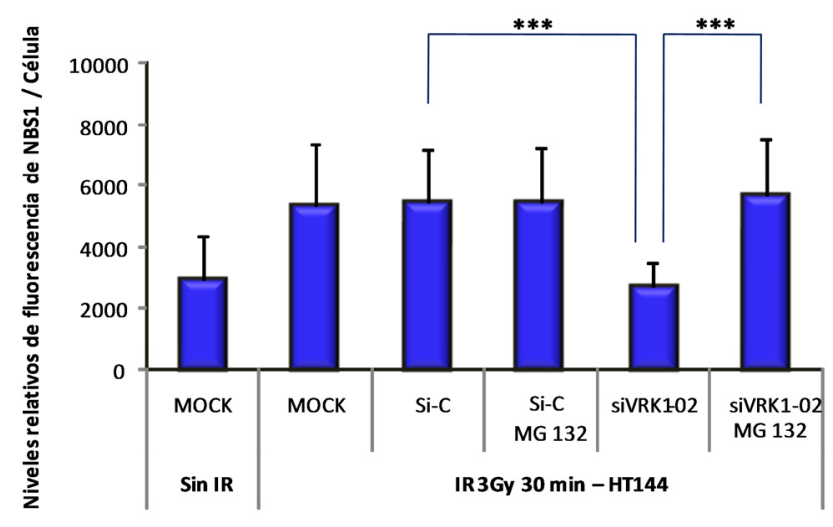

$\begin{array}{lllllll}\text { No Células } & 63 & 73 & 52 & 63 & 48 & 58\end{array}$ 
B

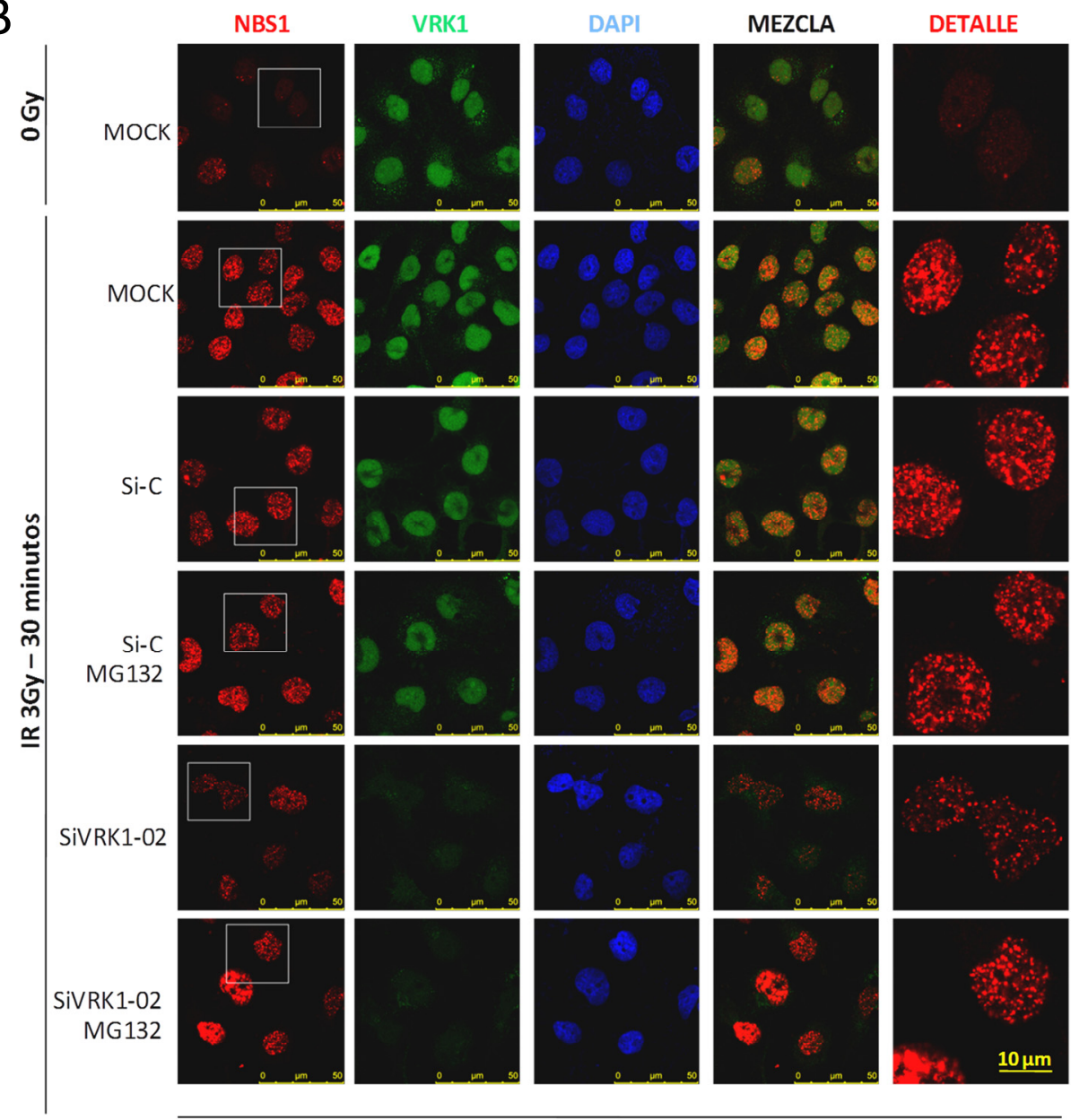

Línea celular GM9607(ATM-/-)

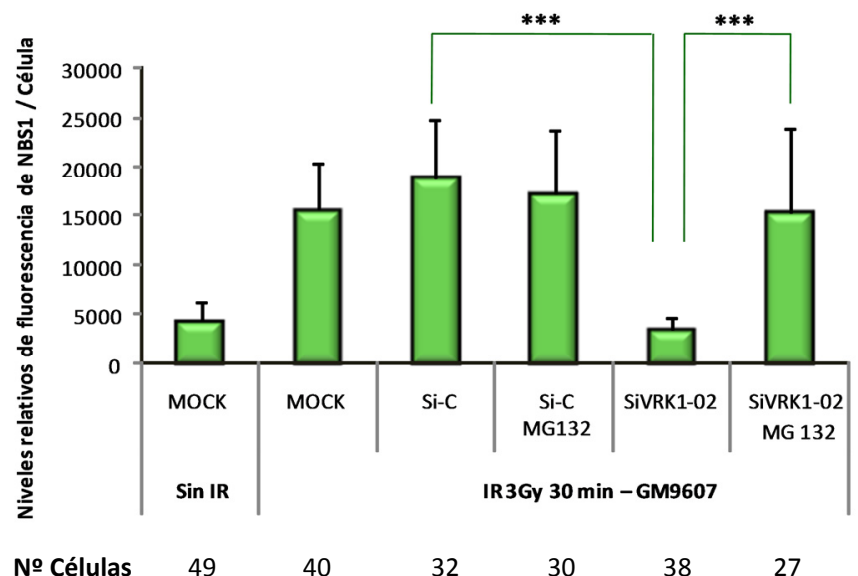




\subsubsection{RNF8 media la degradación de NBS1 en células deficientes de ATM}

Hasta el momento, hemos demostrado que VRK1 es importante para el correcto ensamblaje de focos de NBS1, además, evita la degradación de NBS1 en células deficientes de ATM. Con el fin de investigar el posible mecanismo dependiente de VRK1 por el cual NBS1 está siendo degradado, decidimos llevar a cabo experimentos destinados a estudiar la ubiquitinación de NBS1 y la participación de posibles ubiquitina ligasas que pudieran estar relacionadas con este efecto. El papel de la ubiquitinación en el daño en el ADN puede resultar en el reclutamiento o degradación de proteínas dependiendo del tipo de señal, es decir la formación de cadenas poliubiquitinadas en la $\mathrm{K} 63$ son señal para el reclutamiento, mientras la poliubiquitinación en la lisina K48 es señal para que la proteína sea degradada (Messick \& Greenberg, 2009). En primer lugar, analizamos el papel de la ubiquitina y las ubiquitina ligasas Mdm2 y RNF8 sobre los niveles proteicos de NBS1. Para ello, transfectamos células A549 y HT144 (ATM-/-) con los plásmidos pSSK-HA-Ubiquitina, pCoC-mdm2 y pcDNA3.1-HA-RNF8. Después de 48 horas, los extractos celulares fueron procesados para analizar los niveles de expresión de NBS1. Podemos observar como la sobre-expresión de la ubiquitina y las dos ubiquitina ligasas en las células deficientes de ATM, afectan los niveles totales de NBS1. Sin embargo, estos niveles proteicos de NBS1 son mayormente afectados por la ubiquitina ligasa RNF8 (Figura 58A). De manera contraria, no observamos un efecto similar de la ubiquitina - las ubiquitina ligasas sobre NBS1 en la línea celular A549 (Figura 58B), lo que verifica que el efecto de la degradación de NBS1 sólo se observa en células deficientes de ATM. Dado que la ubiquitina ligasa RNF8 tiene mayor efecto sobre los niveles de NBS1 y que esta es importante en la respuesta al daño en el ADN, decidimos continuar nuestros estudios con esta proteína. Para verificar el resultado anterior, comparamos los niveles de expresión de NBS1 y VRK1 en células A549 o HT144 transfectadas con pcDNA3.1-HA-RNF8 o dejadas sin transfectar. Confirmamos que la sobre-expresión de HA-RNF8 disminuye los niveles de NBS1. Además, los niveles de expresión de VRK1 también fueron afectados en las células deficientes de ATM (Figura 58C). Con el fin de corroborar este efecto sobre la expresión de VRK1 y NBS1, decidimos llevar a cabo una curva de dosis de HA-RNF8 en las células HT144 (ATM-/-) y A549 para ver si el efecto de esta ubiquitina ligasa era dosis dependiente. Detectamos la disminución progresiva de los niveles proteicos de NBS1 y VRK1 de manera dosis dependiente de RNF8 en células deficientes de ATM, efecto no observado en células A549 (Figura 58D). 
A

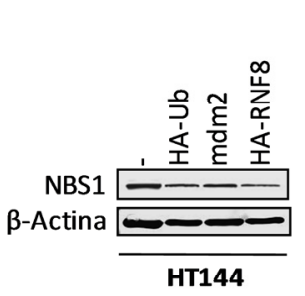

B

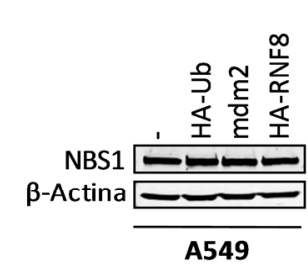

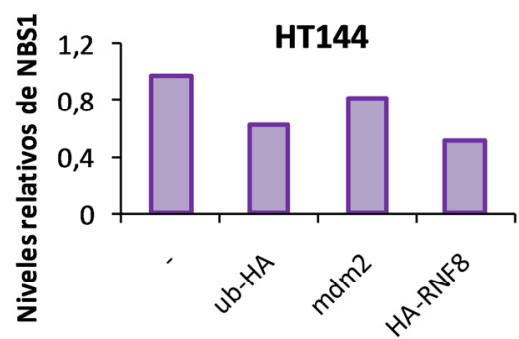

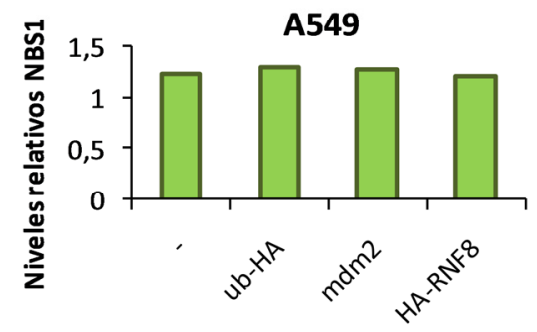

C
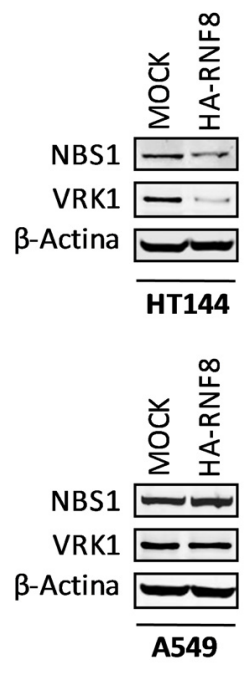

D

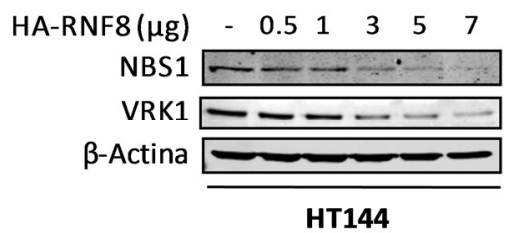

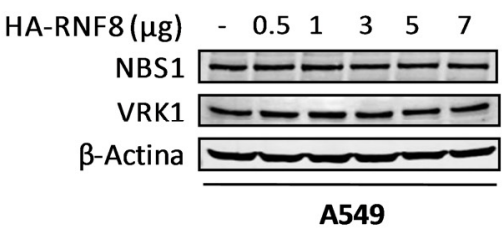

Figura 58. La ubiquitina-ligasa E3 RNF8 media la degradación de NBS1 en células deficientes de ATM. Células HT144 (A) o A549 (B) fueron transfectadas con pSSK-HA-Ubiquitina (1 $\mu \mathrm{g})$ y las ubiquitinas ligasas pCoC-Mdm2 (4 $\mu \mathrm{g})$ o pcDNA3.1-HA-RNF8 $(4 \mu \mathrm{g})$ durante 48 horas. Se detectaron los niveles endógenos de NBS1 con un anticuerpo policlonal especifico en el Western blot. En la parte derecha se muestra la cuantificación de los niveles relativos de NBS1 en las células HT144 y A549 usadas en las figuras A y B, respectivamente. C. Transfección de las células HT144 y A549 con el plásmido pcDNA3.1-HA-RNF8 durante 48 horas. Los extractos fueron usados para detectar los niveles de expresión de NBS1 y VRK1 por Western blot. D. Curva de dosis de pcDNA3.1-HA-RNF8 en células HT144 y A549, mostrando su efecto sobre NBS1 y VRK1. Los niveles de NBS1 y VRK1 se detectaros por Western blot mediante el uso de los anticuerpos policlonales anti-NBS1 y VC, respectivamente. Se detectó los niveles de $\beta$ Actina como control de carga. 
Para constatar que NBS1 es una proteína que puede ser ubiquitinada, llevamos a cabo un ensayo de inmunoprecipitación en la línea celular HEK-293T. Transfectamos los plásmidos pSSK-HA-Ubiquitina y pcDNA3.1-HA-RNF8. Transcurridas 48 horas, inmunoprecipitamos la ubiquitina ligada al epítopo HA con un anticuerpo específico y detectamos la presencia de NBS1 endógeno en el precipitado. Tal y como observamos en la figura 59, se detectó la presencia de NBS1 en el precipitado de HAubiquitina, confirmándonos la ubiquitinación de esta proteína. Sin embargo, no se observaron diferencias en las células transfectadas con pcDNA3.1-HA-RNF8.

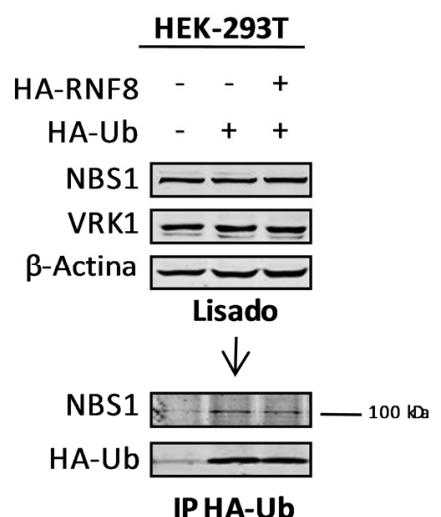

IP HA-Ub
Figura 59. Ubiquitinación de NBS1. Células HEK-293T fueron transfectadas con los plásmidos pSSK-HA-Ubiquitina y pcDNA3.1-HA-RNF8. 48 horas después las células fueron lisadas. El extracto se usó para inmunoprecipitar la ubiquitina con el anticuerpo anti-HA monoclonal y se detectó por Western blot la presencia de NBS1 en el precipitado usando un anticuerpo policlonal específico.

La proteína RNF8 ubiquitina e interacciona con NBS1 antes y después del daño al ADN ayudando al mantenimiento de NBS1 a las DSBs (Lu et al, 2012). Teniendo en cuenta que también hemos demostrado la interacción entre NBS1 y VRK1, quisimos analizar si VRK1 afectaba de alguna manera la interacción entre NBS1 y RNF8. Por lo tanto, células HEK-293T fueron transfectadas con los plásmidos pCMV-FLAG-NBS1, pCDNA3.1-VRK1-Myc y pcDNA3.1-HA-RNF8. Precipitamos la proteína HA-RNF8 con un anticuerpo específico y como control se inmunoprecipitó en paralelo con el anticuerpo AU5 del mismo isotipo. FLAG-NBS1 y VRK1-Myc fueron detectados mediante Western blot. En la figura 60A observamos la interacción entre NBS1 y RNF8, esta interacción no se afecta en presencia de VRK1, al contrario VRK1 cae en el precipitado de RNF8 junto con NBS1, tal vez por la formación de un complejo proteico entre las tres proteínas. En base al resultado anterior, quisimos estudiar si las proteínas RNF8 y VRK1 podrían estar interaccionando directamente. Para ello, llevamos a cabo un ensayo de inmunoprecipitación empleando la proteína HA-RNF8 y detectando la presencia de GST-VRK1 en el precipitado de las células HEK-293T tratadas con doxorubicina o dejadas sin tratar. Detectamos la presencia de VRK1 en el precipitado de RNF8 independiente del tratamiento de doxorubicina (Figura 60B), lo cual podríamos pensar que pueden interaccionar, sin embargo, NBS1 podría estar haciendo de puente y lo que vemos solo sea parte de un complejo. 
A
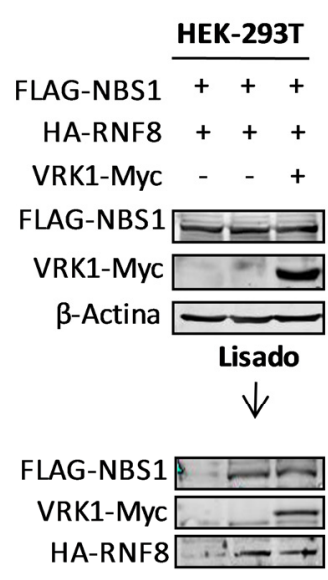

号告
B

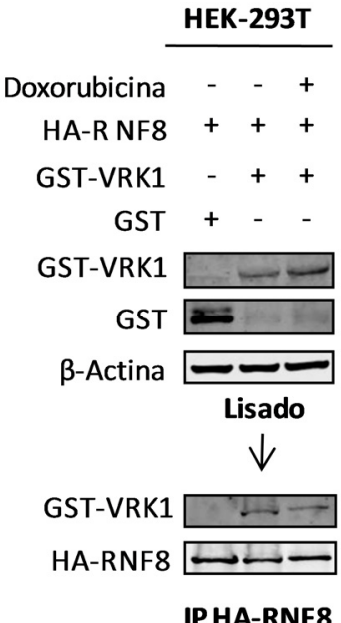

IP HA-RNF8

Figura 60. Interacción entre NBS1, RNF8 y VRK1. A. Células HEK-293T fueron transfectas durante 48 horas con los plásmidos pCMV-FLAG-NBS1, pcDNA3.1-HA-RNF8 y pCDNA3.1-VRK1Myc. Se inmunoprecipitó la proteína HA-RNF8 con un anticuerpo policlonal anti-HA y se detectó la presencia de FLAG-NBS1 y VRK1-Myc en el precipitado con los anticuerpos monoclonales anti-FLAG y anti-Myc, respectivamente. B. 96 horas después de la transfección de las células HEK-293T con los plásmidos pcDNA3.1-HA-RNF8 y pCEFL-GST-VRK1, se realizó inmunoprecipitación de HA-RNF8 con un anticuerpo policlonal específico. Se analizó por Western blot la presencia de GST-VRK1 en el precipitado. 


\section{IMPLICACIÓN DE LA QUINASA HUMANA VRK2 EN APOPTOSIS}

\subsection{Localización subcelular y expresión de VRK2}

Las quinasas VRK1, VRK2A y VRK2B presentan una alta homología en el dominio catalítico por lo que tienden a compartir sustratos in vitro. Sin embargo, las diferencias en sus extremos C-terminal hacen que estas quinasas tengan diferente localización subcelular, por lo que muy probablemente no compartan los mismos sustratos y funciones biológicas in vivo. La quinasa humana VRK2 se encuentra localizada en el citosol o en el núcleo dependiendo de su isoforma. VRK2A tiene un dominio transmembrana en su región carboxi-terminal que le permite estar anclada a membranas del retículo endoplasmático, envoltura nuclear y mitocondrias. Por contra, VRK2B se encuentra en el citosol y predominantemente en el núcleo, debido a que no comparte similitud con la región carboxi-terminal de VRK2A (Blanco et al, 2006). Basándonos en esta referencia, evaluamos la localización subcelular de VRK2 en diferentes tipos de líneas celulares. Para ello, llevamos a cabo ensayos de inmunofluorescencia en las líneas celulares: 293T (células embrionarias de riñón), MCF7 (adenocarcinoma de mama), HeLa (adenocarcinoma de cérvix), A549 (carcinoma de pulmón) y H1299 (cáncer de pulmón de célula no pequeña), donde se detectó la localización de VRK2 con un anticuerpo policlonal específico (anti-VRK2). En la figura $61 \mathrm{~A}$ se puede apreciar como en todas las líneas celulares estudiadas, la localización subcelular de VRK2 es mayoritariamente citosólica y en menor proporción en núcleo, ya que el anticuerpo utilizado detecta ambas isoformas (VRK2A y VRK2B) sin distinción. No se observaron diferencias significativas al comparar la localización de VRK2 en función de la línea celular. Además, decidimos analizar los niveles de expresión de VRK2 en las líneas anteriormente estudiadas mediante Western blot. VRK2A se expresa en todas las líneas celulares, mientras que la expresión de VRK2B es bastante variable dependiendo de la línea celular, observándose mayores niveles de expresión en las líneas celulares de adenocarcinoma de mama (MCF7) y adenocarcinoma de cérvix (HeLa) (Figura 61B). 


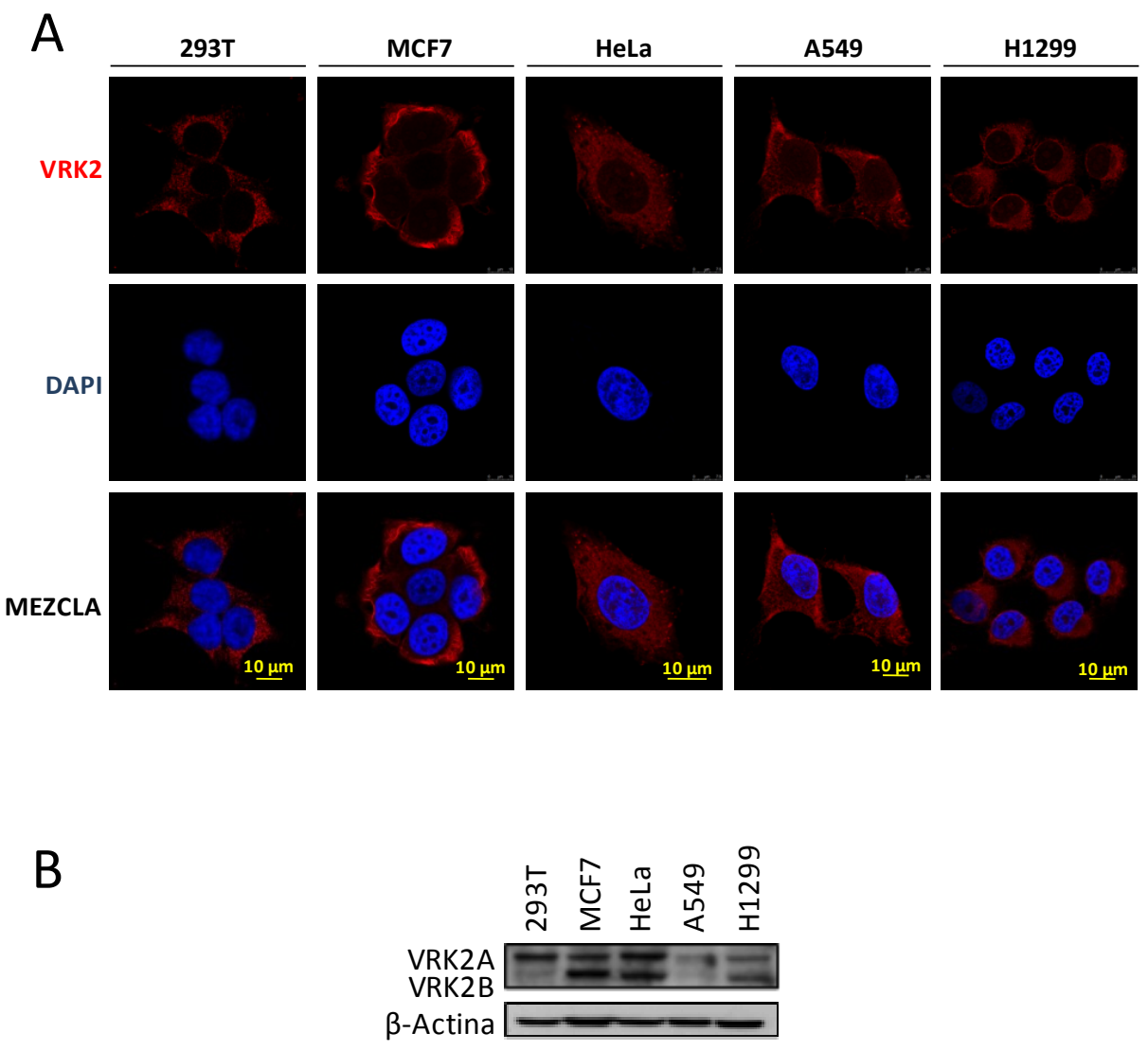

Figura 61. Localización subcelular y expresión de VRK2 en un panel de líneas celulares. A. Transcurridas 48 horas de crecimiento de las líneas celulares HEK-293T (células embrionarias de riñón), MCF7 (adenocarcinoma de mama), HeLa (adenocarcinoma de cérvix), A549 (carcinoma de pulmón) y H1299 (carcinoma de pulmón de célula no pequeña), las células fueron fijadas para inmunofluorescencia. Se detectó VRK2 con un anticuerpo policlonal específico (rojo). Los núcleos se tiñeron con DAPI. La barra indica $10 \mu \mathrm{m}$. B. Se analizaron por Western blot los niveles de VRK2 endógeno en las líneas celulares indicadas en el apartado A. El anticuerpo policlonal anti-VRK2 detecta dos bandas. La banda superior corresponde a la isoforma VRK2A y la banda inferior a la isoforma VRK2B de menor peso molecular.

\subsection{Interacción de VRK2 con proteínas relacionadas con la apoptosis}

\subsubsection{VRK2 colocaliza con $\mathrm{Bcl}-\mathrm{xL}$ y Bax, pero únicamente interacciona con} Bcl-xL

La vía intrínseca de la apoptosis está controlada por una serie de proteínas que participan en la estimulación o inhibición de la permeabilización de la membrana 
externa mitocondrial (MOMP). Estas proteínas pertenecientes a la familia Bcl-2, se dividen en proteínas anti-apoptóticas como $\mathrm{Bcl}-2$ y $\mathrm{Bcl}-\mathrm{xL}$, pro-apoptóticas como Bax y pro-apoptóticas sólo-BH3 subdivididas en activadoras de las proteínas proapotóticas como Bid e inhibidoras de las proteínas anti-apoptóticas como PUMA $\alpha$, Bad o Bnip3L (Youle \& Strasser, 2008). El trabajo realizado por Li y colaboradores en el año 2006 demostró la interacción entre VRK2A y la proteína BHRF1 del virus de Epstein-Barr (proteína homologa a Bcl-2 en mamíferos), teniendo un efecto de protección contra la apoptosis ( $\mathrm{Li}$ et al, 2006). En base a esta información, nos planteamos la posibilidad de que VRK2A pudiera interaccionar o tener algún efecto sobre alguna de las proteínas de la familia $\mathrm{Bcl}-2$, por lo que a manera de primer acercamiento, realizamos inmunofluorescencias para evaluar si VRK2 colocalizaba con la proteína anti-apoptótica Bcl-xL y pro-apoptótica Bax en células A549. Observamos solapamiento de las señales de fluorescencia emitida por VRK2 con Bcl$x L$ y Bax (Figura 62), sugiriendo que se encuentran próximas en el mismo compartimento subcelular, aunque no significando que estén interaccionando directamente.
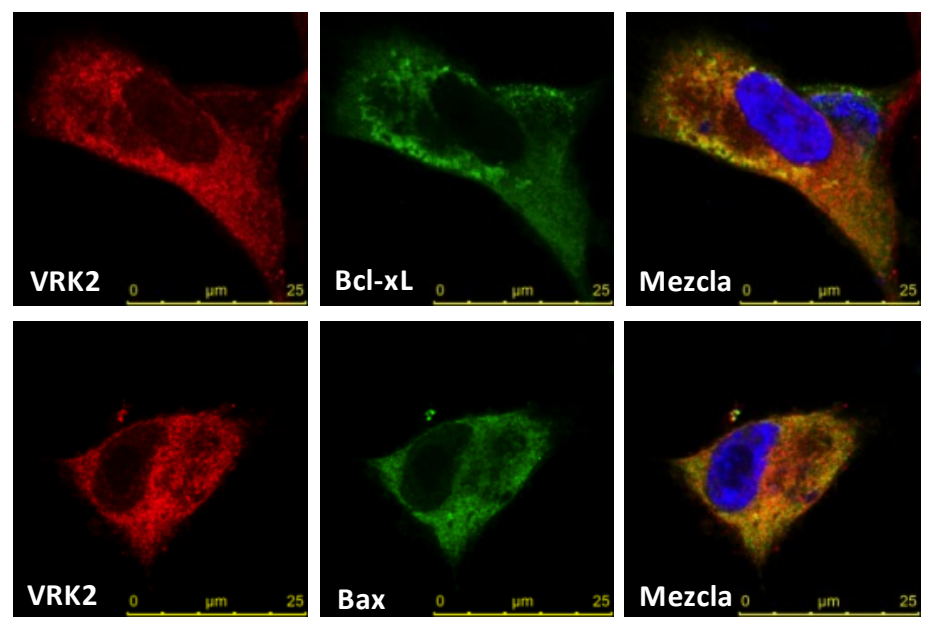

Línea celular A549

Figura 62. Colocalización de la quinasa VRK2 con la proteína anti-apoptótica Bcl-xL y proapoptótica Bax. Células A549 fueron transfectadas con los plásmidos pcDNA3.1-HA-Bcl-xL y p8-AU1-Bax durante 48 horas. Posteriormente las células fueron fijadas para inmunofluorescencia. VRK2 fue detectada con un anticuerpo policlonal específico, mientras que $\mathrm{Bcl}-\mathrm{xL}$ y Bax fueron detectados con los anticuerpos monoclonales anti-HA y anti-AU1, respectivamente. 
Para comprobar si VRK2A interaccionaba directamente con proteínas de la familia $\mathrm{Bcl}-2$ se realizaron ensayos de Pull-down transfectando células HeLa con los plásmidos pCEFL-GST-VRK2A, o bien el plásmido vacío pCEFL-GST. Precipitamos las proteínas sobre-expresadas, empleando la resina glutatión sefarosa. Posteriormente, se detectó la presencia de las proteínas endógenas $\mathrm{Bcl}-\mathrm{xL}, \mathrm{Bcl}-2, \mathrm{y}$ Bax en el precipitado mediante Western blot. Únicamente se evidenció la interacción de VRK2A con la proteína anti-apoptótica $\mathrm{Bcl}-\mathrm{xL}$ pero no con las demás proteínas estudiadas (Figura 63).

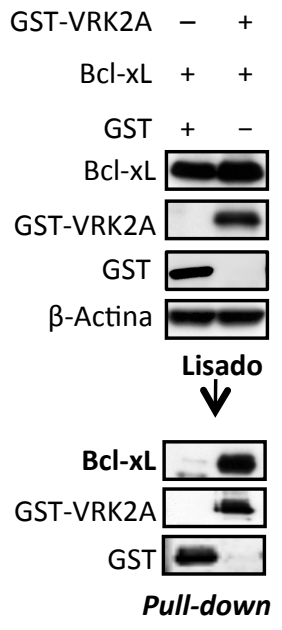

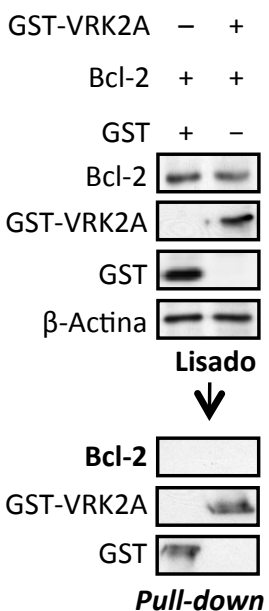

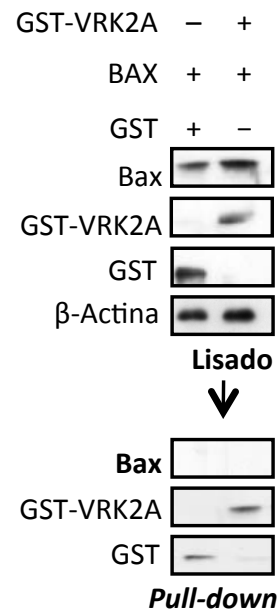

Figura 63. Interacción entre la quinasa VRK2A y las proteínas Bcl-xL, Bcl2 o Bax. Se transfectaron células HeLa con los plásmidos PCEFL-GST-VRK2A y pCEFL-GST. Tras 48 horas, se prepararon los extractos celulares para realizar los ensayos de Pull-down. Para la detección de GST y GST-VRK2 se utilizó el anticuerpo monoclonal anti-GST y para detectar las proteínas endógenas Bcl-xL, Bcl-2 y Bax se emplearon anticuerpos específicos.

Por otro lado, con el fin de descartar una posible interacción entre VRK2A y proteínas pro-apoptóticas soló-BH3, llevamos a cabo ensayos Pull-down en células HEK-293T, transfectando los plásmidos pCEFL-GST-VRK2A y pCEFL-GST en combinación con los plásmidos pCMV-FLAG-PUMA $\alpha$, pcDNA3.1-AU1-Bad o pCR3.1HA-Bnip3L. No detectamos la presencia de las proteínas FLAG-PUMAa, AU1-Bad y HA-Binp3L en el precipitado de GST-VRK2A (Figura 64). De acuerdo a los resultados obtenidos anteriormente, podemos concluir que VRK2A colocaliza con Bcl-xL y Bax pero únicamente interacciona con Bcl-xL. Además de que VRK2A no interacciona con las proteínas pro-apoptóticas soló-BH3. 


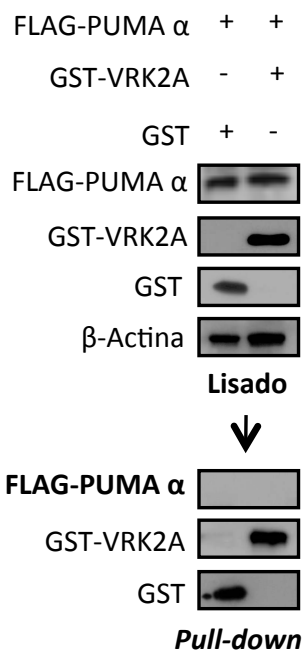

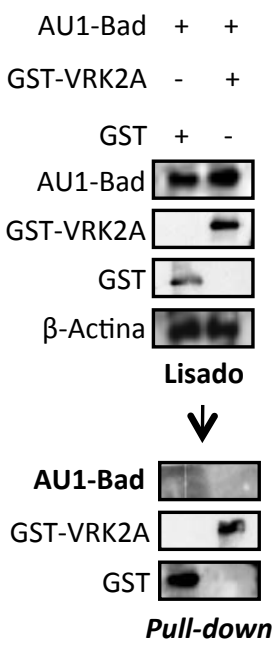

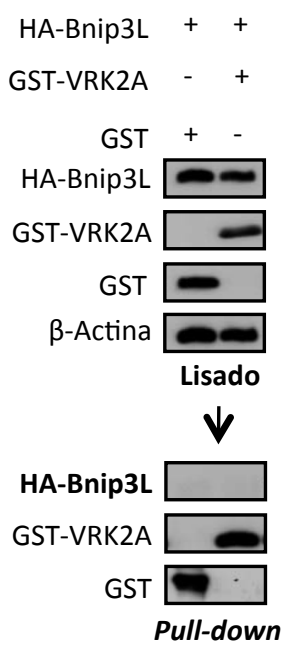

Figura 64. Interacción entre la quinasa VRK2A y las proteínas PUMAa, Bad y Bnip3L. Células HEK-293T fueron transfectadas con los plásmidos pCEFL-GST o pCEFL-GST-VRK2A, en combinación con los plásmidos pCMV-FLAG-PUMAa, pcDNA3.1-AU1-Bad o pCR3.1-HA-Bnip3L. Tras 48 horas, se precipitaron las proteínas fusionadas a GST mediante Pull-down, se utilizó el precipitado del GST vacío como control. Se detectó la presencia de las proteínas en el lisado y el Pull-down mediante el empleo de anticuerpos específicos contra el epítopo.

\subsection{VRK2 regula la expresión de la proteína pro-apoptótica Bax}

Datos obtenidos en nuestro laboratorio muestran la formación de un complejo entre Bax, Bcl-xL y VRK2A. Aunque ya hemos demostrado que VRK2A no interacciona con Bax, conocemos que $\mathrm{Bcl}-\mathrm{xL}$ está actuando como un puente entre estas dos proteínas (Monsalve et al, 2013). Teniendo en cuenta estos datos, nos planteamos si VRK2A podría estar regulando el mecanismo de apoptosis de manera directa o indirecta a través de Bax. En primer lugar, silenciamos la expresión de VRK2 en la línea celular de carcinoma de pulmón (A549) mediante el uso de un ARN de interferencia específico (SiVRK2-06). Tras 96 horas, procesamos los extractos celulares para analizar los niveles proteicos de $\mathrm{Bax}, \mathrm{Bcl}-2$ y $\mathrm{Bcl}-\mathrm{xL}$ por Western blot. La supresión transitoria de la expresión de VRK2 produce un incremento significativo de los niveles proteicos de Bax, tanto de la proteína total reconocida por el anticuerpo antiBax 2D2, como la forma activa de Bax reconocida por el anticuerpo anti-Bax 6A7. Los niveles proteicos de las proteínas anti-apoptóticas $\mathrm{Bcl}-2$ y $\mathrm{Bcl}-\mathrm{xL}$ se vieron reducidos al silenciar la expresión de VRK2 (siVRK2-06) en comparación con el control (si-C) (Figura 65A). Para verificar este resultado, realizamos el mismo experimento, en iguales condiciones, en la línea celular de adenocarcinoma de cérvix 
(HeLa). Se puede apreciar el mismo efecto anteriormente descrito en las células A549. Se observa un incremento de los niveles proteicos de Bax y una reducción de $\mathrm{Bcl}-2$ y Bcl-xL tras el silenciamiento de VRK2 (Figura 65B). Los resultados anteriores sugieren que VRK2 tiene un efecto negativo sobre la expresión de Bax, ayudando a la protección de las células contra la apoptosis.

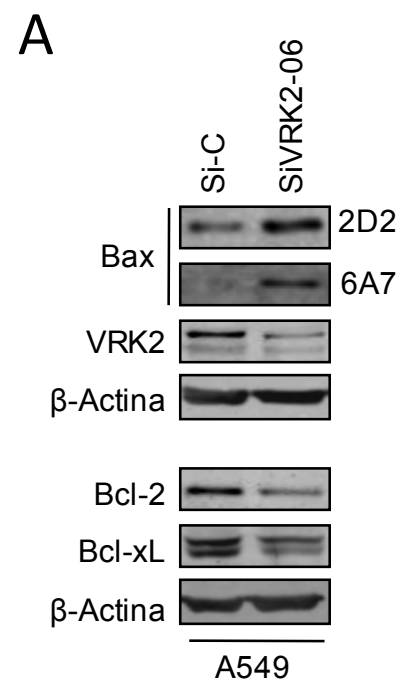

B
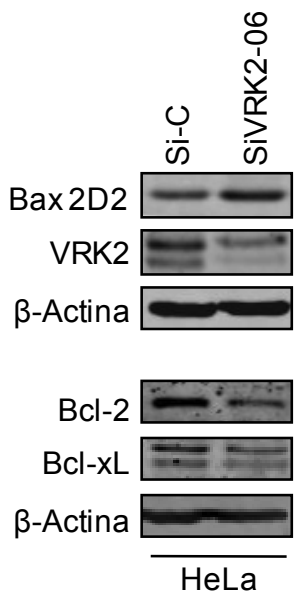

Figura 65. Efecto del silenciamiento de VRK2 sobre proteínas asociadas a la apoptosis. Células A549 (A) o HeLa (B) fueron transfectadas con ARN de interferencia específico para VRK2 (SiVRK2-06) o ARN de interferencia control (Si-C) durante 96 horas. Posteriormente, se detectaron en el Western blot los niveles de proteínas pro-apoptóticas como BAX con los anticuerpos 2D2 (proteína total) y 6A7 (Bax activado) y proteínas anti-apoptóticas como BCL-2 y BCL-XL.

\subsubsection{VRK2 regula la expresión génica de Bax}

Con el fin de determinar si el efecto sobre los niveles proteicos de Bax era consecuencia de la regulación de la expresión génica de esta proteína por VRK2, decidimos estudiar los niveles de ARN mensajero mediante PCR cuantitativa a tiempo real (qRT-PCR). Para ello, transfectamos la línea celular A549 con los oligonucleótidos de ARN de interferencia SiVRK2-06, SiVRK2-08 y Si-Control. 96 horas después, realizamos la extracción del ARN total, el cual fue usado en la qRTPCR para determinar los niveles de ARNm de Bax y VRK2. En la figura 66A, representamos gráficamente los niveles de ARNm de Bax y VRK2, normalizados con el control GAPDH. Los niveles de ARNm de VRK2 disminuyen eficientemente tras la transfección con los dos ARN de interferencia, resultando en un incremento 
significativo (entre 3 y 4 veces) de los niveles de ARNm de Bax. Este resultado nos indica que VRK2 inhibe la expresión génica de Bax. Adicionalmente, se determinaron los niveles de ARNm de las proteínas pro-apoptóticas $\mathrm{Bcl}-2$ y $\mathrm{Bcl}-\mathrm{xL}$, pero no se observaron diferencias significativas tras el silenciamiento de VRK2 (Figura 66B).

A

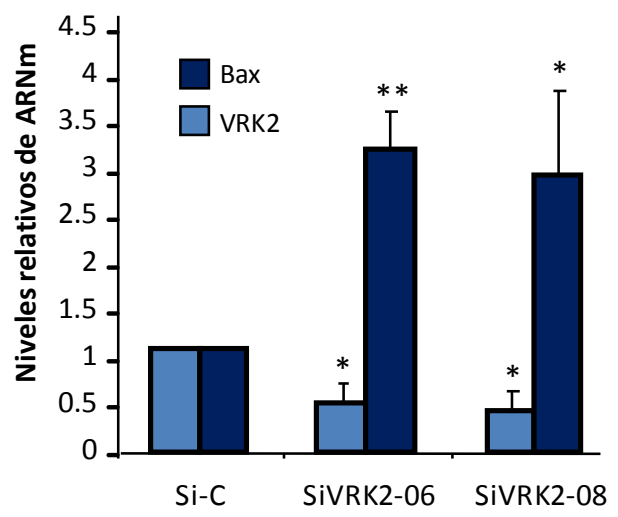

B

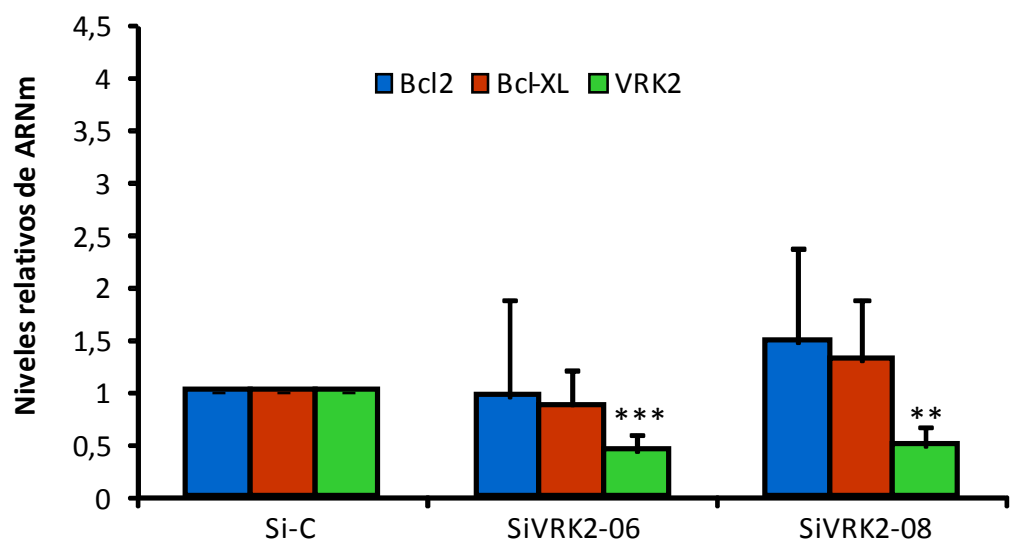

Figura 66. El silenciamiento de la expresión de VRK2 incrementa los niveles de ARNm de Bax pero no afecta los niveles de Bcl-2 y Bcl-xL. A. Células A549 fueron transfectadas con el ARN de interferencia indicado durante 96 horas. Posteriormente, se detectaron los niveles de ARNm mediante qRT-PCR empleando oligonucleótidos específicos para Bax, VRK2 y GAPDH.B. Se realizó el mismo experimento, en iguales condiciones del apartado A. Se utilizó en la qRTPCR los oligonucleótidos para Bcl-2, Bcl-xL, VRK2 y GAPDH. Los niveles de ARNm se normalizaron con respecto al control GAPDH. Se representa la media de 4 experimentos independientes analizados mediante la $t$ Student con respecto al Si-C. ${ }^{* * *}(\mathrm{P}<0,0005),{ }^{* *}(\mathrm{P}$ $<0,005), *(P<0,05)$. 
A continuación, estudiamos si el efecto de VRK2 era mediado por la regulación del promotor del gen de Bax. Para ello, empleamos un gen reportero de luciferasa bajo el control del promotor de Bax (Bax-Luc). Llevamos a cabo ensayos de luciferasa transfectando células A549 con dos ARN de interferencia específicos para silenciar VRK2 (SiVRK2-06 y SiVRK2-08) y el control (Si-C). Tras 48 horas, re-transfectamos la construcción pGL3-Bax-Luc (-687 a -318), para intentar determinar si la activación transcripcional de Bax se veía afectada en ausencia de VRK2. La supresión de la expresión de VRK2 con los dos ARN de interferencia conduce a un incremento de entre 6 a 8 veces de la actividad transcripcional de Bax controlado por su promotor (Figura 67). Tras observar estos resultados, confirmamos que VRK2 regula negativamente la expresión génica de Bax.

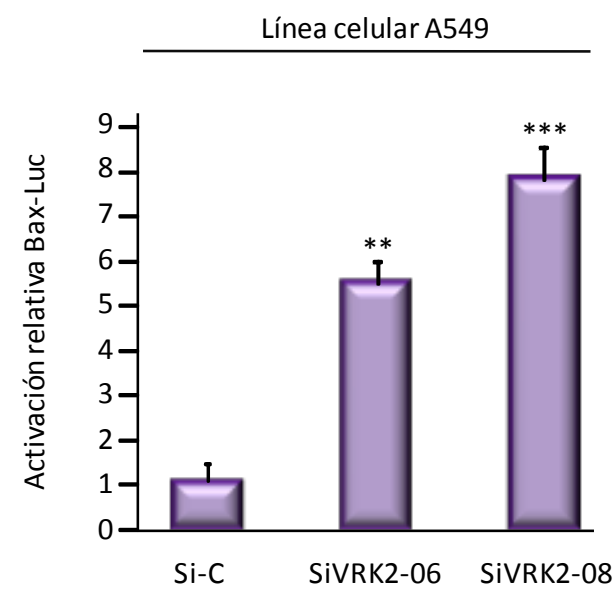

Figura 67. El silenciamiento de la expresión de VRK2 incrementa la activación transcripcional del promotor de Bax-Luc. Células A549 fueron transfectadas con ARN de interferencia específico para VRK2 $(06$ o 08) durante 48 horas, posteriormente se realizó una retransfección del vector PGL3-Bax-Luc $1 \mu \mathrm{g}$. Tras 48 horas las células fueron lisadas y los extractos fueron procesados para medir su actividad luciferasa. Se representa la media de tres experimentos independientes, realizados por triplicado, analizados mediante la t de student con respecto a la actividad del reportero bajo el control del promotor de Bax activado por el Si-C. ${ }^{* * *}(\mathrm{P}<0,0005),{ }^{* *}(\mathrm{P}<0,005),{ }^{*}(\mathrm{P}<0,05)$.

Por último, para confirmar la regulación negativa de VRK2 sobre Bax, quisimos ver si la sobre-expresión de VRK2A podía inhibir la activación de la transcripción de Bax en respuesta a la estimulación con camptotecina. La camptotecina es un fármaco citotóxico que inhibe la enzima topoisomerasa I, produciendo roturas de doble cadena lo que provoca la muerte de la célula (Liu et al, 2000). Llevamos a cabo ensayos de luciferasa, en la línea celular A549, transfectando 1 mg del plásmido 
reportero pGL3-Bax-Luc en combinación con el plásmidos pCEFL-HA-VRK2A o el vector vacío como control. 48 horas después, se trataron las células durante 6 horas con $5 \mu \mathrm{M}$ de camptotecina. Transcurrido este tiempo, se prepararon los extractos celulares y se determinó la actividad luciferasa (Figura 68). Comprobamos que el promotor de Bax fue activado tras el tratamiento con la camptotecina, pero esta activación fue inhibida significativamente por la sobre-expresión de VRK2A. De esta manera, corroboramos que efectivamente VRK2A inhibe la transcripción dirigida por el promotor de Bax.

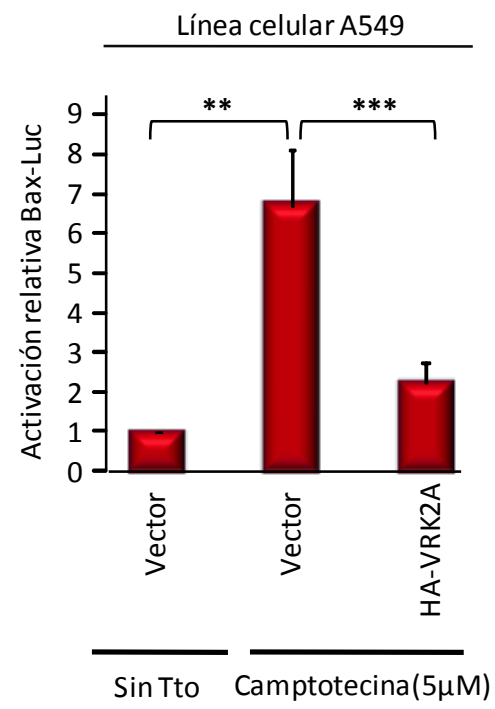

Figura 68. VRK2A inhibe la activación del promotor de Bax por Camptotecina. Células A549 Se transfectaron con $1 \mu \mathrm{g}$ del reportero pGL3-Bax-Luc, en combinación con PCEFL-HA-VRK2A o el correspondiente vector vacío PCEFL-HA. Posteriormente, las células fueron tratadas durante 6 horas con una dosis $5 \mu \mathrm{M}$ de Camptotecina. La sobre-expresión de VRK2A inhibe la activación del promotor de Bax por estímulos que inducen muerte celular. Se representa la media y la desviación estándar de tres experimentos independientes realizados por triplicado $*(p<0,05), * *(p<0,005), * * *(p<0,0005)$.

\subsection{El silenciamiento de la expresión de VRK2 induce la liberación del citocromo c y el procesamiento de PARP}

Una de las subpoblaciones de la proteína VRK2A se localiza en la mitocondria (Blanco et al, 2006), este orgánulo es esencial en el desarrollo de la apoptosis a través de la vía intrínseca, mediando la liberación de proteínas como el citocromo c que inicia la activación de caspasas en el citosol (Martinou \& Youle, 2011). En primer lugar, para 
establecer si verdaderamente el silenciamiento de VRK2 tenía algún efecto sobre la ruta intrínseca de la apoptosis, decidimos estudiar la liberación del citocromo c de la mitocondria y su redistribución en el citosol. Para ello, silenciamos la expresión de VRK2 mediante el empleo de un ARN de interferencia específico (SiVRK2-06) en la línea celular de adenocarcinoma de cérvix (HeLa). Tras 96 horas, los extractos celulares fueron procesados por fraccionamiento con el fin de obtener las fracciones mitocondrial y citosólica separadas. Se detectó la presencia de citocromo c en ambas fracciones mediante el uso de un anticuerpo monoclonal específico en el Western blot. El silenciamiento de la expresión de VRK2 produce un incremento significativo de los niveles de citocromo c en la fracción citosólica, acompañado por una disminución en la fracción mitocondrial (Figura 69A). La liberación del citocromo c al citosol resulta en la activación de caspasas, que a su vez tienen la capacidad de procesar la proteína PARP. El procesamiento de PARP por las caspasas es considerado un marcador distintivo de la apoptosis (Chaitanya et al, 2010). Por este motivo, estudiamos el procesamiento proteolítico de PARP como una consecuencia de la liberación del citocromo c. Así, células HeLa fueron transfectadas con los oligonucleótidos de interferencia SiVRK2-06 y Si-control durante 96 horas. Transcurrido este tiempo, se procesaron los extractos celulares para llevar a cabo Western blot. Pudimos comprobar que al silenciar VRK2 se incrementaban los niveles del PARP procesado (85 kDa) (Figura 69B). Estos resultados nos indican que la supresión de la expresión de VRK2 facilita la inducción de la apoptosis por vía intrínseca. 

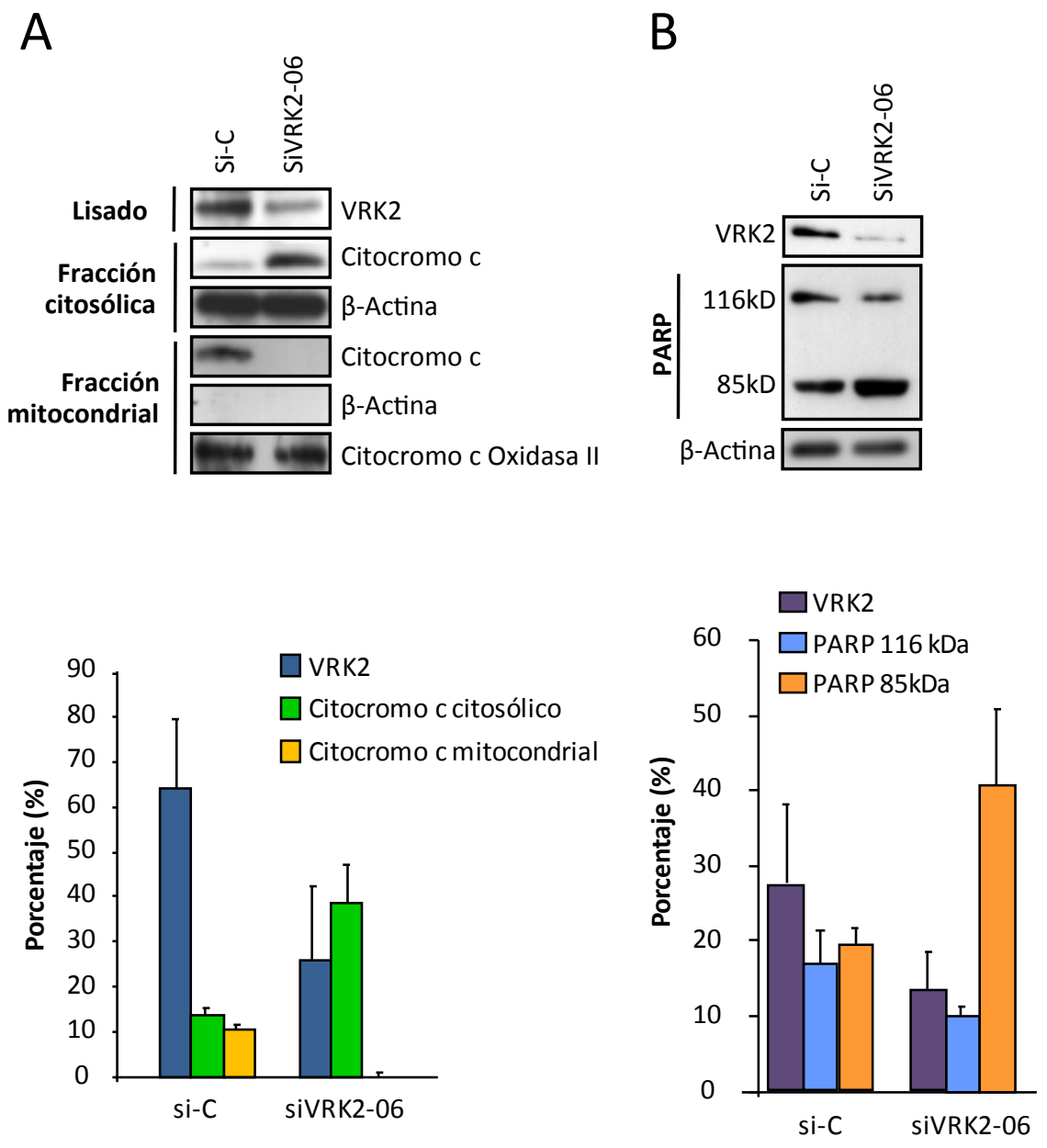

Figura 69. El silenciamiento de la expresión de VRK2 facilita la liberación del citocromo c y el procesamiento de PARP. A. La liberación de citocromo c fue determinada mediante su detección en las fracciones citosólica y mitocondrial de extractos celulares de HeLatransfectadas con siVRK2-06 y Si-C durante 96 horas. Se emplearon los anticuerpos policlonal anti-VRK2 y monoclonales anti-citocromo $\mathrm{c}$ y anti- $\beta$ actina para la detección de sus correspondientes proteínas en el Western blot. En la gráfica inferior se muestra la cuantificación de la intensidad de las bandas de VRK2 y citocromo c, representado en porcentaje con respecto a su correspondiente marcador. La $\beta$-Actina y el citocromo $c$ oxidasa II fueron usados como marcadores de las fracciones citosólica y mitocondrial, respectivamente. B. Células HeLa fueron transfectadas con los ARN de interferencia SiVRK2-06 y Si-C durante 96 horas. Posteriormente se determinó el procesamiento proteolítico de PARP mediante la detección de dos bandas ( 115 y $85 \mathrm{kDa}$ ) empleando el anticuerpo monoclonal anti-PARP en el Western blot. Se representan los niveles proteicos como porcentaje de la intensidad de las bandas. La representación de la cuantificación de los Western blot muestran la media y la desviación estándar de tres experimentos independientes. 


\subsection{El silenciamiento de la expresión de VRK2 sensibiliza las células al tratamiento con camptotecina}

El incremento de la apoptosis como consecuencia de los bajos niveles de la quinasa VRK2, sugiere que las células podrían ser más sensibles a la quimioterapia. Por este motivo, nos planteamos evaluar si la deficiencia de VRK2 producía un incremento en la apoptosis inducida por camptotecina. Este fármaco es utilizado en quimioterapia y su mecanismo de acción se basa en la inducción de daño en el ADN. Para el desarrollo de la apoptosis se requiere la translocación de Bax a la membrana mitocondrial y posterior liberación del citocromo c. Por lo tanto, evaluamos por técnica de fraccionamiento la distribución de Bax y citocromo c en las fracciones citosólica y de membranas de extracto de células HeLa transfectadas con Si-control y SiVRK2-06 durante 96 horas y posteriormente tratadas con $5 \mu \mathrm{M}$ de camptotecina durante diferentes tiempos. Las células HeLa que fueron silenciadas con el ARN de interferencia específico para VRK2 presentaron un incremento de los niveles de citocromo c en el citosol después de 3 horas del tratamiento con camptotecina. Sin embargo, en las células HeLa transfectadas con Si-Control también se observó un incremento de citocromo $\mathrm{c}$ en el citosol pero después de 6 horas de tratamiento. Además, se observó la aparición de Bax más tempranamente (3 horas posttratamiento) en las fracciones de membrana correspondiente a las células transfectadas con SiVRK2-06 en comparación a las células transfectadas con Sicontrol donde la aparición de Bax se observó después de 6 horas de tratamiento con camptotecina (Figura 70). Estos resultados nos indican y confirman que el silenciamiento de la expresión de VRK2 facilita la translocación de Bax a la membrana mitocondrial y como consecuencia la liberación del citocromo c al citosol, acelerando el mecanismo de apoptosis inducido por camptotecina. 

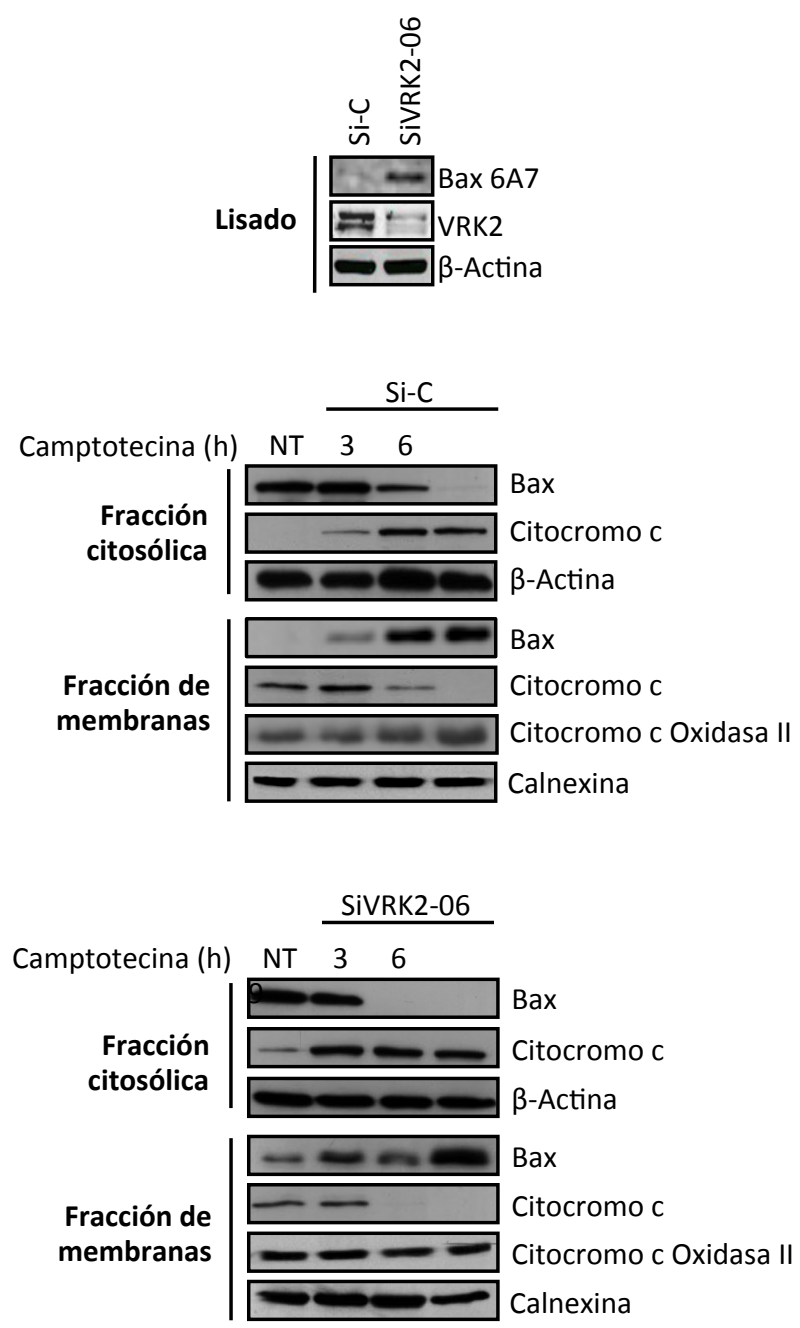

Figura 70.El silenciamiento de la expresión de VRK2 sensibiliza las células a la camptotecina. Células HeLa fueron transfectadas con los ARN de interferencia Si-Control y SiVRK2-06 durante 96 horas. Posteriormente, las células fueron tratadas con $5 \mu \mathrm{M}$ de camptotecina a diferentes tiempos. Se realizó fraccionamiento y se aisló el citosol de las membranas, de esta manera se determinó la distribución de Bax y citocromo c en ambas fracciones empleando los anticuerpos correspondientes para cada proteína en el Western blot.

A la vista de los resultados anteriores, quisimos determinar el efecto del silenciamiento de VRK2 en células tratadas con camptotecina sobre el efecto de la activación de caspasas en el procesamiento proteolítico de PARP. Para ello, transfectamos células HeLa con los oligonucleótidos de interferencia Si-control y SiVRK2-06 durante 96 horas. Transcurrido este tiempo las células fueron tratadas con camptotecinaa diferentes tiempos. El silenciamiento de la expresión de VRK2 
provocó que las células fueran más sensibles a la camptotecina al observarse la pérdida de PARP (116 kDa), el cual es completamente procesado después de 6 horas de tratamiento, incrementándose los niveles de PARP procesado (85 kDa) (Figura 71A). Además, para verificar este resultado, realizamos el mismo experimento empleando un ARN de interferencia diferente (SiVRK2-M) específico para VRK2. Tal y como esperábamos obtuvimos un resultado similar, se observó el procesamiento proteolítico de PARP (116 kDa), al aparecer una banda de $85 \mathrm{kDa}$ correspondiente al PARP procesado después de 6 horas de tratamiento con camptotecina (Figura 71B). Por lo tanto, concluimos que el silenciamiento de VRK2 ayuda a promover la apoptosis inducida por camptotecina.

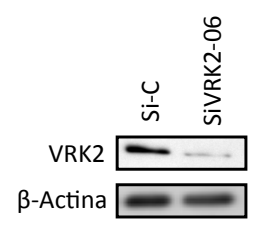

Camptotecina $(5 \mu \mathrm{M})$

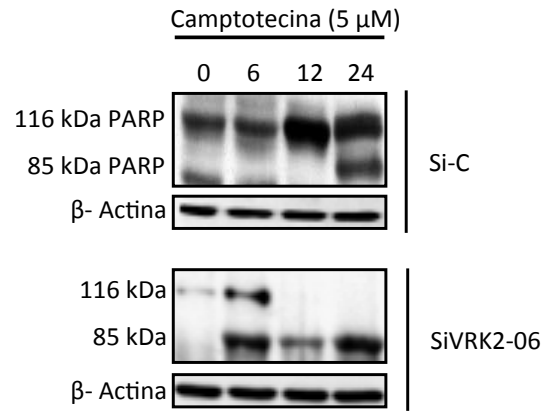

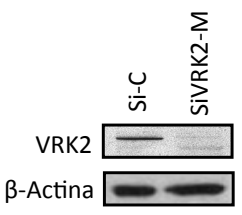

Camptotecina $(5 \mu \mathrm{M})$

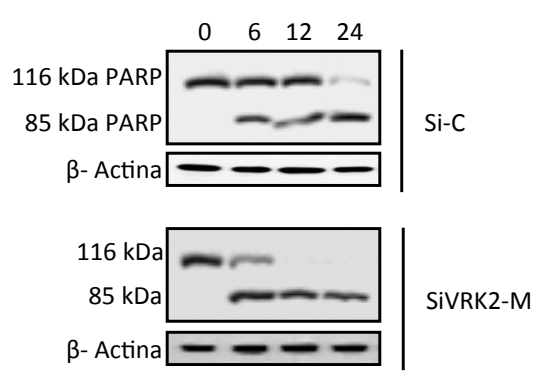

Figura 71. Silenciamiento de la expresión de VRK2 facilita la activación de caspasas y por ende al procesamiento proteolítico de PARP en respuesta a camptotecina. Células HeLa fueron transfectadas con siVRK2-06 (A), SiVRK2-M (B) o con Si-Control. 96 horas después las células fueron tratadas con $5 \mu \mathrm{M}$ de camptotecina a diferentes tiempos. Los niveles de PARP total (116 kDa) y PARP procesado $(85 \mathrm{kDa})$ se detectaron con un anticuerpo monoclonal específico en el Western blot.

Por último, decidimos evaluar el efecto de la camptotecina y el procesamiento de PARP sobre el daño en el ADN. La camptotecina inhibe la topoisomerasa tipo I lo cual puede provocar roturas en el ADN. Por otro lado, el procesamiento de PARP inducido por la activación de apoptosis, hace que esta proteína importante en la reparación del $A D N$, sea inactivada resultando en un incremento en el daño génico (Oliver et al, 1999). Por tal motivo, el efecto del silenciamiento de VRK2 sobre la 
respuesta a camptotecina fue analizado por ensayo TUNEL. Este ensayo se basa en la detección de la fragmentación del ADN en respuesta a estímulos apoptóticos. Así, células A549 fueron transfectadas con el ARN específico para VRK2 (SiVRK2-06) y un ARN de interferencia control (Si-C) durante 96 horas. Posteriormente, las células fueron tratadas con $5 \mu \mathrm{M}$ de camptotecina durante 6, 12 o 24 horas, o dejadas sin tratar. Se puede apreciar en la figura 72 que las células con bajos niveles de expresión de VRK2 presentaron mucho antes (12 horas post-tratamiento) un incremento en el número de células con daño en el ADN en comparación a las células transfectadas con Si-Control. Todos estos resultados, nos permiten concluir que las células son más sensibles a la muerte celular por apoptosis si los niveles de expresión de VRK2 son bajos.
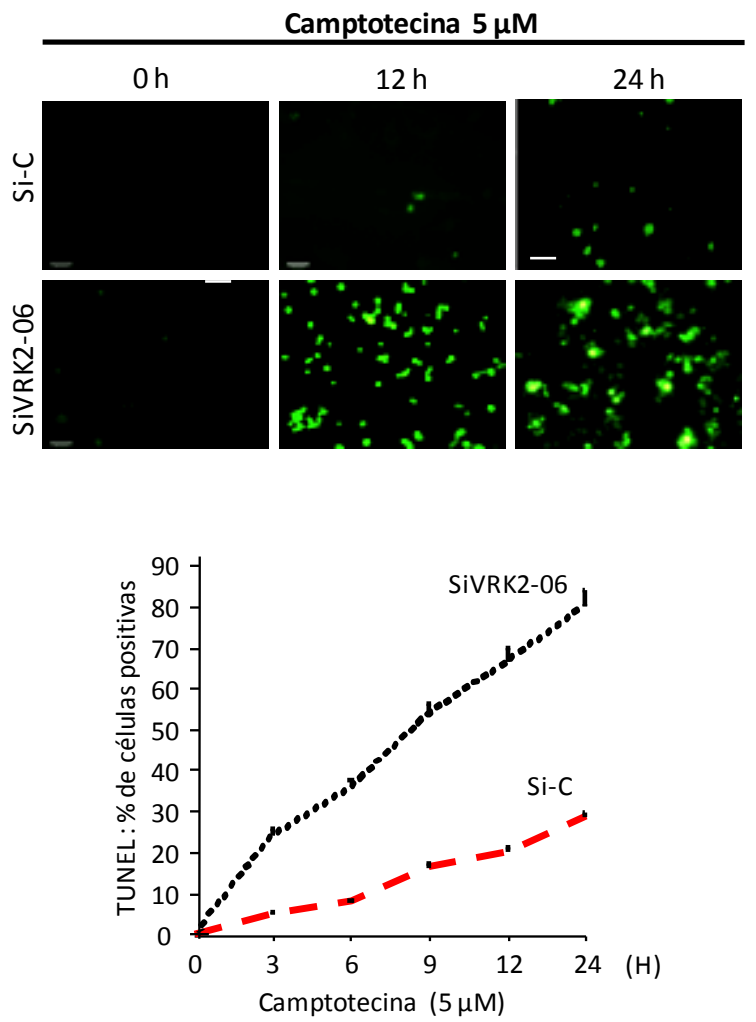

Figura 72. El silenciamiento de la expresión de VRK2 ayuda a la inducción de daño en el ADN por camptotecina. Se transfectaron células A549 durante 96 horas con los ARN de interferencia indicados. Posteriormente, las células fueron tratadas con $5 \mu \mathrm{M}$ de camptotecina a diferentes tiempos. Se realizó ensayo TUNEL para detectar la presencia de los extremos libres del ADN asociados a daño génico. Las células fueron teñidas con florescina12dTUP (rTdT) y analizadas en miscroscopio de fluorescenica. La gráfica representa el porcentaje de células positivas en el ensayo TUNEL. 


\section{DISCUSIÓN}





\section{IMPLICACIÓN DE LA QUINASA HUMANA VRK1 EN LA RESPUESTA AL DAÑO EN EL ADN}

\subsection{Actividad y localización de VRK1 en respuesta a estímulos genotóxicos}

La quinasa VRK1 está implicada en la acumulación y activación del factor de transcripción p53 (Lopez-Sanchez et al, 2014; Vega et al, 2004). p53 se activa en respuesta a diferentes tipos de daño en el ADN a través de diversas quinasas (ATM, ATR, CK2, Chk1 o Chk2) (Lakin \& Jackson, 1999; Meek, 2004), participando en el control y mantenimiento de la integridad del genoma y mediando procesos como la parada del ciclo celular, la apoptosis o la reparación del ADN (Lakin \& Jackson, 1999). Basándonos en esta información y en el conocimiento previo de que VRK1 puede ser activada en respuesta a diferentes estímulos que producen daño genotóxico como radiación ionizante (IR), luz UV, doxorubicina o etopósido, además de participar en el ensamblaje de los focos de 53BP1 (Sanz-Garcia et al, 2012), consideramos la necesidad de estudiar la función de VRK1 en la modulación de la respuesta al daño en el ADN. En este trabajo hemos intentado profundizar en el estudio de la rápida respuesta de VRK1 y su función sobre proteínas como NBS1 y MDC1, importantes en la reparación del ADN lesionado.

Para estudiar la localización, actividad y funciones de VRK1 en la respuesta al daño en el $A D N$, se utilizaron principalmente dos estímulos (IR y doxorubicina) que inducen roturas de doble cadena (DSBs), independientemente de su eficacia, con el fin de verificar si la actividad de VRK1 respondía a las DSBs de manera independiente de la causa. En la actualidad las radiaciones ionizantes se utilizan en procesos de investigación, diagnóstico y tratamiento. A nivel clínico se utilizan fuentes radiactivas encapsuladas como Iridio ${ }^{192}$, Cesio $^{137}$ o Cobalto $^{60}$ para radioterapia, donde su uso adecuado y por tiempo determinado ayudan a la destrucción de las células cancerosas (Baskar et al, 2012). Por otro lado, la doxorubicina, es utilizada en quimioterapia para el tratamiento de diferentes tipos de cáncer (ovario, tiroides, pulmón, estómago, sarcoma, leucemias, entre otros). Este agente se intercala en el ADN e inhibe la progresión de la enzima topoisomerasa II, produciendo la formación de DSBs (Nitiss, 2009). En nuestros experimentos, observamos resultados similares al utilizar ambos tipos de estímulos (IR o doxorrubina) puesto que ambos producen DSBs (Lee et al, 2005), de tal forma que sus diferencias se observan principalmente en la intensidad y el tiempo necesario para producir el daño. 
En primer lugar, se confirmó la activación de VRK1 en respuesta a IR, evidenciando el incremento de su actividad quinasa (niveles de autofosforilación) 5 minutos después del estímulo. Además, en ensayos de inmunofluorescencia observamos un incremento en la emisión de fluorescencia al utilizar el anticuerpo anti-VRK1 1b5, cuyo epítopo está ubicado en la región carboxi-terminal de la proteína. Este aumento de fluorescencia probablemente sea debido a cambios post-traduccionales que sufre la proteína tras la formación de DSBs producidas por la IR, de forma que el anticuerpo 1 b5 puede reconocer más fácilmente y mejor a su epítopo. Sin embargo, este efecto no se observó en la detección de VRK1 con el anticuerpo 1 b5 en Western blot, debido seguramente a la desnaturalización de la proteína para la realización de la electroforesis. Este incremento en la fluorescencia de VRK1 también fue observado en células tratadas con doxorubicina, pero cabe anotar que este incremento fue mucho menos marcado en comparación a la IR. Este menor aumento se debe probablemente a que la IR (rayos gamma) produce un daño homogéneo en todas las células, mientras que agentes como la doxorubicina tienen una acción dependiente de su capacidad de penetrar la membrana plasmática celular (Gewirtz, 1999). Cabe destacar además que, la luz UV, la cual produce dimerización de pirimidinas y roturas de cadena sencilla del ADN, también induce la activación de VRK1, lo que nos haría pensar que VRK1 se activa independientemente del tipo de daño, siendo desconocida aún su relación directa con la ruta dependiente de ATR la cual es directamente activada en respuesta a luz UV (Cimprich \& Cortez, 2008; UnsalKacmaz et al, 2002). Se evidencia así como la quinasa humana VRK1 juega una importante función en las respuestas celulares activadas a consecuencia de la alteración en la continuidad de las cadenas del ADN; sin embargo, en este trabajo, solo nos centraremos en la activación de la ruta de señalización concerniente a las roturas de doble cadena.

Hasta el momento no existe suficiente información que explique cuáles son los mecanismos que regulan la expresión del gen de VRK1 ni la actividad de esta proteína en respuesta a la entrada o salida del ciclo celular. Cuando hay parada del ciclo celular, se reducen los niveles de expresión de ARN mensajero de VRK1 (Valbuena et al, 2008), además de observarse una marcada reducción en su actividad quinasa (Sanz-Garcia et al, 2012). No obstante, los niveles proteicos de VRK1 se mantienen relativamente altos debido a la larga vida media de la proteína (Valbuena et al, 2008). La actividad de VRK1 en condiciones normales de crecimiento es regulada por fosforilaciones en la misma quinasa, puesto que se ha demostrado que el tratamiento con fosfatasa alcalina reduce los niveles de actividad de VRK1. Estas fosforilaciones pueden ser llevadas a cabo por otras quinasas o por autofosforilación de la propia VRK1. VRK1 presenta fuerte autofosforilación in vitro en múltiples residuos, de los cuales se destaca la treonina 355 (Barcia et al, 2002). La deficiencia de factores de crecimiento en células sin suero conduce a la parada del ciclo celular $y$, por ende, a una disminución en la actividad de VRK1, la cual se recupera tras la re- 
adición de suero (Sanz-Garcia et al, 2012). Por lo tanto, se podría pensar que la activación de diferentes rutas de señalización por factores de crecimiento mediaría la respuesta de VRK1. Una de las principales rutas activadas por estímulos con factores de crecimiento es la relacionada con las MAP quinasas, que regula la proliferación, diferenciación, movilidad y supervivencia celular (Cargnello \& Roux, 2011). Se conoce que las MAP quinasas p38 y ERK pueden activar quinasas nucleares como MSK1 y MSK2 (del inglés: mitogen and stress activated kinase) en respuesta a estímulos mitógenicos (Arthur, 2008; Deak et al, 1998; Roux \& Blenis, 2004). La exposición a radiación ionizante produce daño en el ADN por generación de especies reactivas de oxígeno (ROS) con la posterior activación de ATM y p53, además de poder activar receptores de factores de crecimiento que a su vez cambian la actividad de la familia de proteínas transductoras RAS, produciendo la activación de múltiples vías de señalización, tales como la vía de MAP quinasas y PI3 quinasa, relacionadas con el crecimiento y supervivencia celular (Valerie et al, 2007). Para explicar cómo se activa VRK1 en respuesta a radiación ionizante podríamos pensar que esta quinasa puede ser activada indirectamente a través de la vía de MAP quinasas después de producirse el daño. Sin embargo, Deng y colaboradores demostraron que la activación de ERK (vía MAP quinasa) se presentaba entre 30 minutos y una hora después del estímulo con IR (Deng et al, 2012), mientras que la activación de VRK1 es rápida (alrededor de 5 minutos después de IR), por lo tanto aunque no sea directa la activación por MAPK si podría contribuir. Además, para dar validez a esta hipótesis, sería necesario realizar estudios de la regulación de VRK1 a través de esta vía. Por otro lado, no debemos descartar que la rápida activación de VRK1 sea por otro mecanismo más directo, por ejemplo por autofosforilación de la propia proteína sin necesidad de la fosforilación de otras quinasas en respuesta a IR, como ocurre en el caso de la quinasa ATM, la cual es activada rápidamente tras IR a través de su autofosforilación en el residuo serina 1981 y otros cambios posttraduccionales que hacen que esta quinasa se ubique en la etapa más temprana de la ruta de señalización en respuesta a las DSBs (Bakkenist \& Kastan, 2003).

Tras la formación de las DSBs por IR o doxorubicina, se forman los focos de reparación que están constituidos por el reclutamiento y acumulación de gran cantidad de copias de proteínas que participan en la respuesta al daño en el ADN (DDR) (Bekker-Jensen \& Mailand, 2010). Aunque muchas de las proteínas implicadas en la reparación de lesiones al ADN formen focos discretos debido a su reclutamiento, VRK1 no muestra este comportamiento $y$, tras la estimulación, se mantiene de manera difusa en el compartimento nuclear. Este hecho no significa que VRK1 no participe en la DDR o no forme parte de los focos de reparación. Podemos comparar este comportamiento de VRK1 con la quinasa que presenta un papel similar en la respuesta al daño en el ADN: la quinasa ATM. Tras producirse daño en el ADN, ATM se activa por autofosforilación y este ATM activado se encuentra formando parte de los focos de $\mathrm{HH} 2 \mathrm{AX}$, NBS1, MDC1 o 53BP1 al 
interaccionar y fosforilar a estas proteínas (Kastan \& Lim, 2000; Khanna et al, 2001). Aun así, ATM también se encuentra difusa por el núcleo, esto se debe a que ATM tiene otras funciones fuera de los focos de reparación, como por ejemplo la fosforilación de la proteína p53 en el nucleoplasma (Banin et al, 1998; BekkerJensen et al, 2006; Saito et al, 2002). Por otro lado, Chk2 no forma focos discretos, ya que interacciona transitoriamente en los focos de reparación, debido a que su función principal es la transmisión de señales a través de la fosforilación de sus sustratos como cdc25, p53 y E2F1, entre otros (Bekker-Jensen et al, 2006; Li \& Stern, 2005). De tal manera, VRK1 posee un comportamiento similar a ATM o Chk2 en cuanto a su localización tras el daño en el ADN. Por otro lado, hemos observado en algunos ensayos, tras 30 minutos post-irradiación, que una subpoblación de VRK1 se localizaba en el nucléolo. Andersen y colaboradores, aislaron nucléolos de células HeLa y detectaron la presencia de gran diversidad de proteínas, entre ellas las proteínas quinasa VRK1 y ATM, mostrando que estas son secuestradas en este compartimento celular (Andersen et al, 2005). Por el momento, no hemos profundizado en la razón por la cual VRK1 se localiza en el nucléolo tras IR, pero cabe destacar su probable relevancia debido a que este compartimento celular participa también en procesos de respuesta a daño al ADN o estrés celular (Antoniali et al, 2014; Boulon et al, 2010); lo que nos confirmaría aún más la importancia de la quinasa VRK1 en este tipo de respuesta celular inmediata.

\subsection{Papel de VRK1 sobre proteínas clave en la reparación del ADN}

Basándonos en los resultados obtenidos en nuestro laboratorio sobre el efecto de VRK1 en la fosforilación y el correcto reclutamiento de 53BP1 a los focos de reparación en respuesta a radiación ionizante (Sanz-Garcia et al, 2012), concluimos que VRK1 juega un papel importante en el desarrollo de la respuesta al daño en el ADN. Por tal motivo, decidimos estudiar el efecto de VRK1 sobre la proteína mediadora MDC1, proteína necesaria para el ensamblaje y mantenimiento de 53BP1 en los focos de reparación (Bekker-Jensen et al, 2005; Eliezer et al, 2009). Observamos en nuestros resultados que al suprimir la expresión de VRK1 con un ARN de interferencia específico no se afectaba la formación de focos de MDC1 en respuesta a radiación ionizante o doxorubicina. Sin embargo, al realizar experimentos de interacción entre proteínas, sí evidenciamos la interacción entre VRK1 y MDC1, probablemente debido a que 53BP1 se esté comportando como un puente entre ambas proteínas. Para poder descartar esta posibilidad, se tendrían que realizar estudios de interacción silenciando la expresión de 53BP1 y verificando si continúa habiendo interacción entre MDC1 y VRK1, de no ser así, el resultado nos indicaría que es una interacción indirecta por la formación de un complejo proteico entre las tres proteínas. Así, el hecho de que los focos de MDC1 no se vean afectados tras el silenciamiento de VRK1, resultado contrario a lo que esperábamos 
previamente, nos sugiere la existencia de una ruta alternativa en la formación de dichos focos, independientemente de las quinasas VRK1 y ATM. Diversos estudios han demostrado que la cinética de formación de focos de MDC1 fue normal en células deficentes de ATM, DNA-PKcs y en células con bajos niveles de ATR, gracias al uso de un ARN de interferencia específico (Goldberg et al, 2003). Estos datos nos indican que la formación de focos de MDC1 puede ser mediada por la participación de otras quinasas. Un claro ejemplo de ello es la quinasa serina-treonina CK2 (del inglés: casein kinase 2), esta quinasa modula la función de varias proteínas que participan en la reparación del daño en el ADN, tales como XRCC1/4, rad 9 y DNAPKcs (Kroonen et al, 2012). La CK2 también participa en las DSBs, a través de la fosforilación de los motivos SDT de MDC1, ayudando a la interacción directa entre MDC1 y NBS1, de tal forma que esta quinasa podría contribuir a la formación del foco de reparación (Jungmichel \& Stucki, 2010) (Lukas et al, 2011).

En base a nuestros resultados, hemos posicionado a VRK1 en el ápice de la respuesta a las DSBs, facilitando la eficiente reparación de estas lesiones. Por este motivo consideramos que VRK1 puede tener un papel similar a la quinasa ATM en la respuesta al daño, quinasa que también se activa rápidamente en respuesta a DSBs, fosforilando una gran variedad de sustratos entre los que se encuentra la proteína NBS1 (Gatei et al, 2000; Wu et al, 2000). NBS1 hace parte del complejo Mre11-Rad50 que se encarga de detectar las DSBs y de reclutar y activar completamente a ATM (Lee \& Paull, 2004; Uziel et al, 2003; You et al, 2005). Además, NBS1 es una proteína adaptadora encargada de reclutar proteínas que sirven como sustratos para ATM, facilitando la transmisión de la señal y contribuyendo a la especificidad de la respuesta (Williams et al, 2010; Yuichiru Saito, 2013). Por todas estas características y su función como proteína sensora, decidimos estudiar si existía alguna relación o efecto de VRK1 sobre la proteína NBS1. En primer lugar, detectamos la interacción entre VRK1 y NBS1. Esta interacción, a diferencia de lo que ocurre con 53BP1, se da en ausencia de daño, además de no necesitar la presencia de ATM. NBS1 puede interaccionar con varias proteínas en ausencia de daño. Se ha descrito que la ubiquitina-ligasa Mdm2 se une al complejo MRN a través de la interacción directa con NBS1 en ausencia de daño, no observándose cambios en la cantidad de Mdm2 asociada a NBS1 tras producirse daño (Alt et al, 2005). Por otro lado, Jang y colaboradores demostraron que la proteína acetiltransferasa p300 puede interaccionar con NBS1 independientemente del daño. La fosforilación de p300 por ATM ayuda a la estabilidad y reclutamiento de NBS1 en los sitios de ADN lesionado (Jang et al, 2011). A continuación, quisimos evaluar la interacción de NBS1 con los diferentes miembros de la familia VRK. Observamos la interacción de VRK1, VRK2A y VRK2B con NBS1. Dado que VRK1 y VRK2 son los miembros que comparten mayor homología entre sí (44\%) (Nichols \& Traktman, 2004), era de esperar que NBS1 pudiera interaccionar con todas ellas. Sin embargo, como pudimos demostrar, tan solo VRK1 participa en la respuesta al daño en el ADN, probablemente por su 
localización subcelular mayoritariamente nuclear (nucleoplasma y asociada a la cromatina) (Kang et al, 2007). Además, gracias a ensayos de interacción utilizando distintas construcciones de VRK1, pudimos demostrar como VRK1 interacciona con NBS1 a través de regiones compuestas por aminoácidos presentes tanto en la región $\mathrm{N}$-terminal como C-terminal, tal vez debido a su estructura terciaria.

Los cambios post-traduccionales, como la fosforilación de proteínas, tienen un papel muy importante en la coordinación y transmisión de la respuesta a lo largo de una vía de señalización, ayudando al control espacio-temporal de la localización de las proteínas, sus interacciones y su activación (Huen \& Chen, 2008). En la respuesta al daño en el ADN, este tipo de modificaciones son relevantes ya que gran cantidad de proteínas son reguladas a través de ellas (Oberle \& Blattner, 2010). ATM es una quinasa central en la respuesta a las DSBs, participando en una gran variedad de procesos a través de la fosforilación de sus sustratos en residuos serina o treonina seguidos de glutamina (Kurz \& Lees-Miller, 2004). Sin embargo, la participación de otras quinasas también es primordial para el correcto desarrollo de la ruta de señalización, como por ejemplo la fosforilación sobre MDC1 por CK2 en sitios serinaaspártico-treonina regulando su interacción con NBS1 (Chapman \& Jackson, 2008). Puesto que las modificaciones post-traduccionales, concretamente las fosforilaciones, son primordiales; es factible pensar que NBS1 pudiera ser fosforilada por otras quinasas, además de ATM, con el fin de mediar la reparación del ADN tras el daño. Por tal motivo, VRK1 parece ser una candidata idónea debido a su rápida activación tras el daño y a su interacción con NBS1. Además, a través del marcaje de focos de NBS1 en un panel de líneas celulares, pudimos ver como en células deficientes de ATM también se formaban focos de NBS1, lo que nos indicaba que seguramente existía una vía alternativa en respuesta a daño en la que ATM no tendría un papel único en el reclutamiento de dicha proteína.

La mayoría de quinasas fosforilan en secuencias diana que se mantienen conservadas en la gran mayoría de sus sustratos. En el caso de la quinasa VRK1, su secuencia diana suele ser una región básica rica en lisinas (Sanz-Garcia et al, 2011), mientras que la quinasa ATM, como se ha mencionado anteriormente, fosforila en residuos serina o treonina seguidos por una glutamina. En este trabajo, hemos demostrado que la proteína NBS1 es sustrato de la quinasa humana VRK1. Este resultado nos muestra como quinasas con secuencias consenso dispares pueden, sin embargo, en ocasiones, fosforilar a residuos en regiones que difieren de la secuencia consenso. Este es el caso de la serina 343 de NBS1, la cual hemos demostrado que es fosforilada por VRK1, además de por ATM. Sin embargo, no es un caso excepcional, ya que este suceso se ha podido evidenciar anteriormente con la proteína 53BP1, la cual es fosforilada tanto por ATM (Ward et al, 2003) como por VRK1 (Sanz-Garcia et al, 2012) en el residuo serina 25/29. El residuo serina 343 de NBS1 es importante para el control de la fase $S$ del ciclo celular así como también para la regulación 
downstream de la ruta de señalización (Lim et al, 2000; Zhao et al, 2000), además de ayudar a modular y amplificar la actividad de ATM (Horejsi et al, 2004). Suponemos que este residuo en NBS1 es diana directa de VRK1 ya que en ensayos en líneas celulares con o sin deficiencia de ATM en las cuales también hemos silenciado a VRK1, los niveles de fosforilación detectados con un anticuerpo fosfo-específico disminuyen significativamente respecto al control después de la estimulación (IR o doxorubicina). Para confirmar este resultado, se debería realizar un ensayo quinasa utilizando un mutante no fosforilable en este residuo (S343A), de tal forma que, ante una bajada en la señal de fosforilación de NBS1, podríamos concluir que es un residuo diana directa de VRK1 pero que existen otros posibles residuos candidatos a ser fosforilados. En caso de que se perdiera la fosforilación, podríamos afirmar que la serina 343 sería el único residuo diana de VRK1. Otra técnica con la que poder comprobar si esta serina 343 es directamente fosforilada por VRK1, es la realización de un ensayo in vitro con la proteína NBS1 purificada y utilizando un anticuerpo fosfo-específico contra dicho residuo, de tal forma que evitaríamos la presencia de otras quinasas que nos pudieran enmascarar el resultado. Además, sabiendo que VRK1 media directa o indirectamente la fosforilación de este residuo de NBS1 tras el daño al ADN y que estas proteínas interaccionan independiente del daño, quisimos evaluar si la sustitución del residuo por el aminoácido alanina que no puede ser fosforilado, afectaría la interacción entre VRK1 y NBS1. Observamos que el mutante no fosforilable de NBS1 tenía mayor interacción con VRK1 en comparación con la proteína silvestre, dato que nos podría reafirmar que NBS1 es sustrato de VRK1, dado que una mayor unión al mutante no fosforilable puede ser debido, a la incapacidad de la quinasa de fosforilar a su sustrato y no poder disociarse.

Como se ha mencionado anteriormente no debemos descartar la posibilidad que VRK1 fosforile otros residuos de NBS1 diferente a la serina 343. Mediante el uso del programa GPS 3.0 (del inglés: group-based prediction system) (http://gps.biocuckoo.org) para la predicción de posibles sitios diana de fosforilación, utilizamos la secuencia de NBS1 como diana y VRK1 como la quinasa de búsqueda, obteniendo varios residuos posibles de fosforilación. Sin embargo, destacamos 2 residuos, las serinas 410 y 442, las cuales obtuvieron el mayor puntaje, por lo que podríamos pensar que son buenas candidatas de estudio. Un claro ejemplo de la importancia de la fosforilación de otros residuos de NBS1, además de que estos puedan ser fosforilados por otras quinasas diferentes a ATM, ha sido demostrado recientemente por Falck y colaboradores. Este estudio describe al residuo serina 432 de NBS1 como blanco de la quinasa CDK, fosforilación que ocurre en la fase S, G2 y M del ciclo celular. La actividad de CDK sobre NBS1 promueve la resección de las DSBs y por consiguiente la activación de la recombinación homóloga, efecto dependiente del complejo MRN (Falck et al, 2012). 
Una vez se confirmó la interacción entre VRK1 y NBS1, interacción que sucede independientemente de ATM, y que la quinasa VRK1 fosforila a NBS1 al menos en el residuo serina 343, quisimos estudiar el reclutamiento y posterior formación de focos de NBS1 tras la estimulación con IR o doxorubicina. Está descrito que NBS1 es rápidamente reclutada a las DSBs en respuesta al daño inducido por radiación ionizante (Assenmacher \& Hopfner, 2004; Kobayashi et al, 2004). Sin embargo, evidenciamos que al silenciar la expresión de VRK1 se afectaba el correcto ensamblaje de los focos de NBS1, observándose una reducción de más del 70\% de la presencia de NBS1 en los focos de reparación. Este resultado se reproduce también en células deficientes de ATM, lo que hace resaltar la importancia de la quinasa humana VRK1 en el inicio de la ruta en respuesta al daño en el ADN. Existen varias proteínas que ayudan al reclutamiento y mantenimiento de NBS1 en los focos de reparación, entre ellas MDC1. Se ha demostrado que el silenciamiento de MDC1 con un ARN de interferencia específico provocando una reducción en el número de focos de NBS1, 53BP1 y BRCA1, tras la irradiación (Stewart et al, 2003). Este resultado era de esperar ya que el reclutamiento de MDC1 a los focos de reparación conlleva a la acumulación del complejo MRN por retroalimentación positiva (Coster \& Goldberg, 2010). Por otro lado, ya conocemos que VRK1 es una quinasa implicada en el ciclo celular, provocándose una parada del ciclo en G0 cuando ésta es silenciada (Valbuena et al, 2008). Por tal motivo, en los ensayos de fluorescencia, los focos de NBS1 fueron también detectados en células crecidas con baja concentración de suero con el fin de asegurar que el efecto observado era debido al silenciamiento de VRK1 y no a un efecto secundario por parada del ciclo celular. Por esta misma razón, también al realizar los ensayos quinasa in vitro disminuimos la actividad de VRK1 retirando el suero, de tal forma que al estimular las células con IR nos aseguramos que el incremento de la actividad de VRK1 es dependiente de este estímulo. Finalmente, teniendo en cuenta que VRK1 fosforila a la serina 343 de NBS1 y que, además, es una quinasa esencial para la formación de los focos de dicha proteína, sería de gran interés hacer ensayos de inmunofluorescencia para observar la formación de focos de NBS1 en células con o sin deficiencia de ATM a las que se ha silenciado VRK1 pero detectándolos con el anticuerpo fosfo-específico para esta serina. Así, podríamos confirmar si este residuo es imprescindible para la formación de focos tras el daño con IR o doxorubicina o si hay más residuos candidatos a formar parte del proceso de reclutamiento de esta proteína.

A continuación, en la figura 73 resumimos el efecto de VRK1 sobre el reclutamiento de proteínas importantes en la reparación del ADN. Como hemos demostrado en el transcurso de este trabajo, VRK1 es necesaria para la correcta formación de focos de NBS1 y 53BP1 pero no de MDC1. 


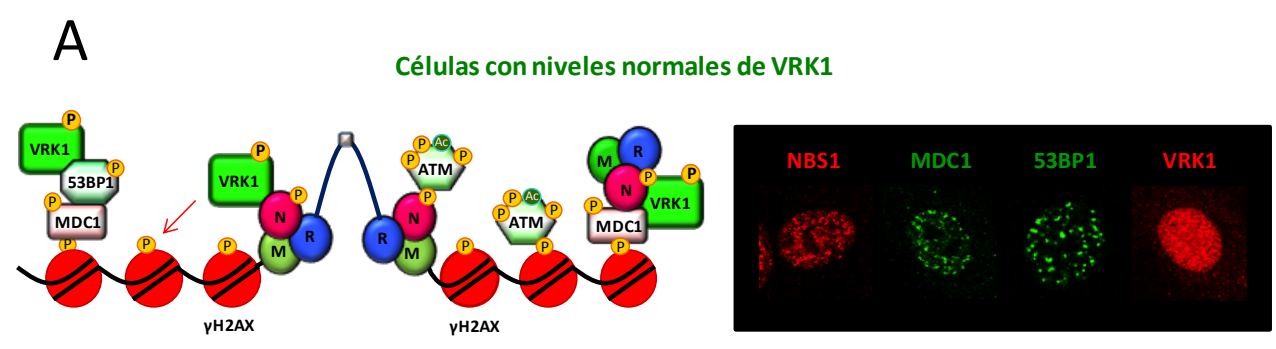

B

Células con bajos niveles s de VRK1
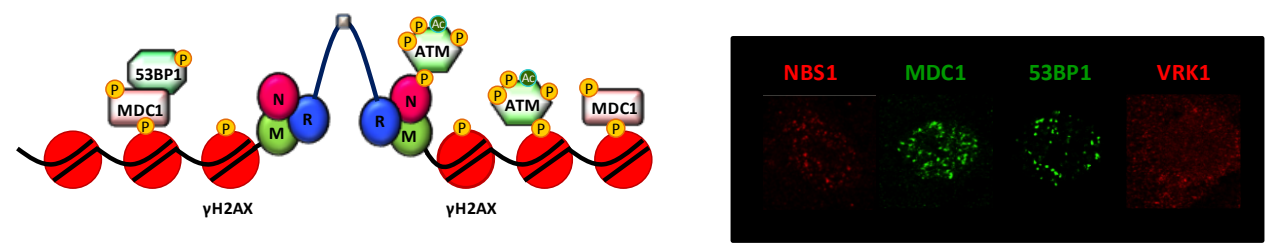

Figura 73. Esquema de la participación de VRK1 en la formación de focos de reparación. A. En células con niveles normales de VRK1 se reclutan las proteínas NBS1, MDC1 y 53BP1 de manera eficiente. Sin embargo, en células que presentan bajos niveles de VRK1 (B) causado por la supresión de la expresión por un ARN de interferencia, se observa una alteración en la formación de focos de NBS1 y 53BP1. P: residuos fosforilados. Ac: residuos acetilados.

Tras la producción de las roturas de doble cadena, el complejo MRN es reclutado a los sitios de lesión, donde posteriormente es reclutada la quinasa ATM la cual fosforila a la histona H2AX y a NBS1 (Kang et al, 2005; Lee \& Paull, 2004). La fosforilación de esta histona hace que la proteína NBS1 pueda interaccionar directamente con ella reteniéndola en el sitio de la lesión (Kobayashi et al, 2009; Kobayashi et al, 2002). En nuestro laboratorio, se ha demostrado que el silenciamiento de VRK1 afecta a la fosforilación del residuo serina 139 de la histona $\mathrm{H} 2 \mathrm{AX}(\mathrm{\gamma} 2 \mathrm{AX}$ ) afectando así a la formación de focos de esta proteína (Sanz-Garcia et al, 2012). Por lo tanto, posiblemente el efecto de VRK1 sobre el ensamblaje de los focos de NBS1 no solo sea de forma directa, sino también de manera indirecta a través de su efecto sobre $\mathrm{pH} 2 \mathrm{AX}$. Por otro lado, Yuan y colaboradores muestran en su estudio que las funciones del complejo MRN pueden ser llevadas a cabo de forma independiente de la fosforilación de esta histona (Yuan \& Chen, 2010). Así, nos inclinaríamos más a pensar sobre la función directa de VRK1 en el reclutamiento de NBS1 a los focos de reparación.

Todos estos resultados sugieren que, VRK1, media una ruta de señalización alterna y paralela a ATM, posicionándose en el ápice de la ruta de señalización. Hemos observado que los niveles de fosforilación del residuo serina 1981 de ATM se afectan tras el silenciamiento de VRK1. Aunque sabemos que VRK1 y ATM no se fosforilan 
entre sí, pensamos que el silenciamiento de VRK1, el cual impide el correcto reclutamiento de NBS1 a los focos de lesión, afectaría de manera indirecta al reclutamiento y activación de ATM. Esta hipótesis está basada en varios trabajos donde se ha demostrado que NBS1 es clave para que ATM se localice y active completamente en los sitios de ADN lesionado (Uziel et al, 2003; You et al, 2005). Concluimos así que VRK1 es una quinasa que coopera con ATM por una vía alterna en la regulación de la vía de señalización en respuesta a daño en el ADN.

VRK1 interacciona con NBS1, y se ha descrito que existe interacción entre las proteínas ATM y NBS1 tras producirse daño (Falck et al, 2005), por lo que nos planteábamos una posible competencia entre VRK1 y ATM. Después de realizar ensayos de inmunoprecipitación, corroboramos la existencia de un complejo proteico entre VRK1, NBS1 y ATM. Se deberían realizar ensayos de silenciamiento de NBS1 para confirmar una interacción directa entre VRK1 y ATM, ya que solo con nuestros resultados podríamos estar viendo una interacción entre ambas proteínas debido a la existencia de un puente entre ellas formado por NBS1.

Como hemos demostrado a lo largo de esta tesis, muchos de los resultados obtenidos relacionados con la función y actividad de VRK1 sobre proteínas del daño al ADN, como NBS1, son similares y, en ocasiones, redundantes, en comparación con las funciones de ATM. Sin embargo, este no es el único caso. Se ha observado también redundancia funcional entre ATM y la quinasa ATR (Cimprich \& Cortez, 2008), donde esta última tiene entre sus funciones cooperar con el mantenimiento de la fosforilación de sustratos que comparte junto a ATM (Stokes et al, 2007). Si seguimos comparándolas, vemos como ATM es activada por IR y fármacos que producen DSBs, mientras que ATR responde a SSBs producidas por estrés replicativo o luz UV. Además, ATM es reclutada a los sitios de lesión por el complejo MRN, mientras que ATR es reclutada por la proteína ATRIP, y, una vez reclutadas, fosforilan una gran variedad de sustratos con el fin de inducir la parada celular y facilitar la reparación del ADN (Falck et al, 2005). De este modo, estas dos quinasas pueden tener funciones parecidas o cruzadas que, aunque pueden ser redundantes, son necesarias para la coordinación de la reparación del daño. Sin embargo, como se ha mencionado anteriormente, en nuestro laboratorio, se ha demostrado que VRK1 es capaz de activarse en respuesta a DSBs inducidas por IR en presencia o ausencia de ATM (Sanz-Garcia et al, 2012). Esto sugiere que VRK1 ayudaría a la coordinación de los eventos necesarios para la correcta reparación de las DSBs en una vía alternativa a ATM, aunque ambas quinasas podrían estar cooperando mutuamente en la regulación de la respuesta al daño en el ADN, sin descartar la posibilidad de que las dos rutas alternas puedan unirse o no en una regulación espacio-temporal. La participación de VRK1 en la reparación de las DSBs se refleja en el modelo propuesto en la figura 74. 


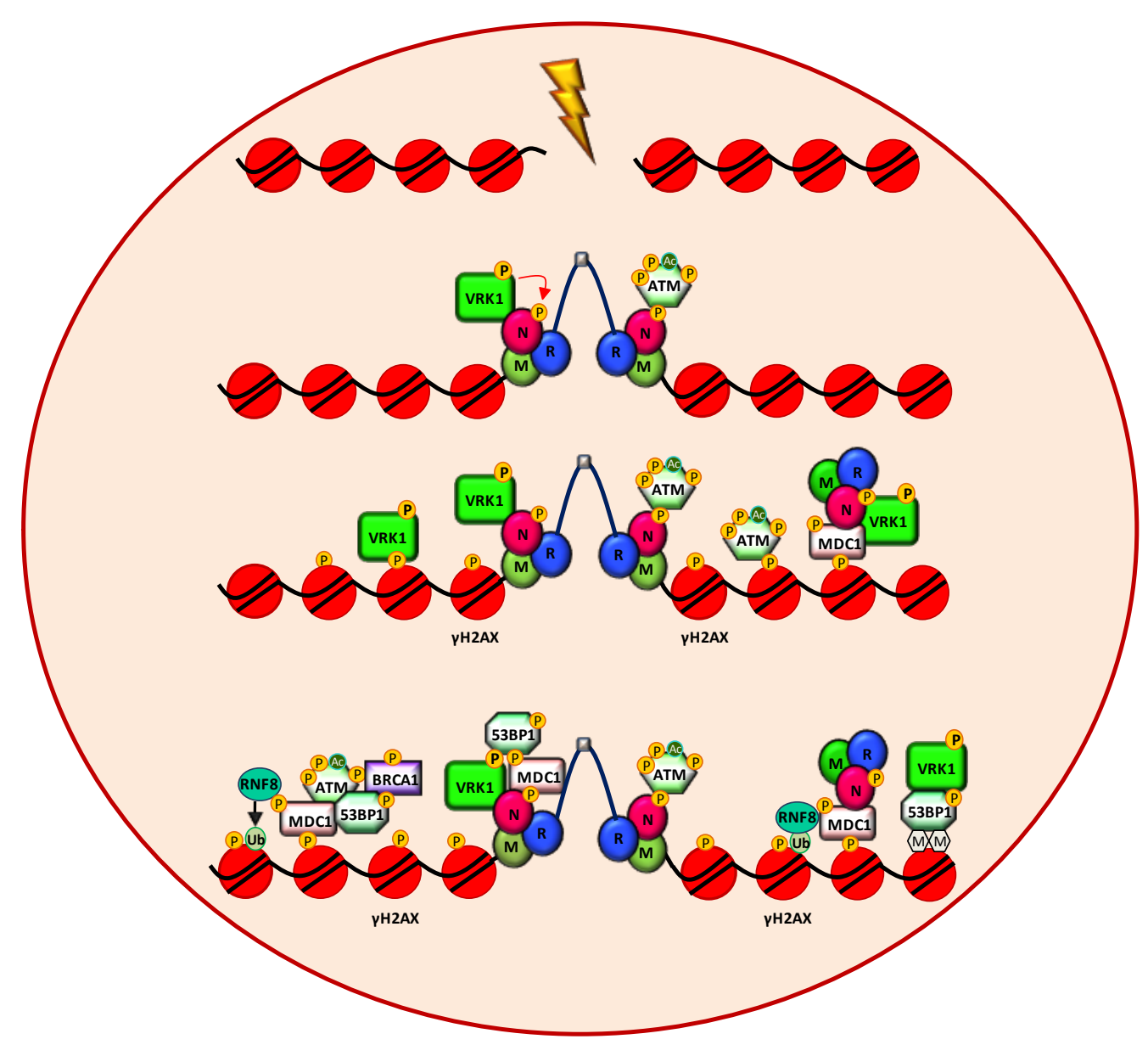

Figura 74. Mecanismo propuesto para explicar la participación y modulación de VRK1 en la reparación de las roturas de doble cadena del ADN. VRK1 se activa rápidamente tras la formación de DSBs producidas por radiación ionizante o fármacos quimioterapéuticos como la doxorubicina. VRK1 tiene efecto a varios niveles de la ruta de señalización. En primer lugar, VRK1 interacciona y fosforila a NBS1, ayudando a la formación de focos de esta proteína. También interviene en la fosforilación de H2AX y 53BP1 para mediar la correcta transmisión de la señal y de esta forma la reparación del ADN lesionado. $\mathrm{p}$ : residuos fosforilados, $\mathrm{M}$ : residuos metilados y Ub: residuos ubiquitinados. 


\subsection{Papel de VRK1 en la degradación de NBS1}

Tras observar que el silenciamiento de VRK1 en células con o sin presencia de ATM afectaba la formación de focos de NBS1, evidenciamos que, en células deficientes de ATM y tratadas con ARN de interferencia específico para VRK1, disminuían los niveles proteicos de NBS1 por Western blot, efecto que no observábamos en células con presencia de ATM. Este resultado nos podría explicar el posible mecanismo por el cual NBS1 no es reclutado correctamente a los focos de reparación. Así, podríamos pensar en que ATM y VRK1 son necesarias para mantener la estabilidad proteica de NBS1 y que, la deficiencia de una de ellas, seria suplida por la otra quinasa, de tal forma que, en ausencia de ambas, los niveles de NBS1 disminuirían drásticamente. Además, realizando ensayos con inhibidores de ATM, como el compuesto KU55933 o la cafeína, confirmamos que este efecto en la estabilidad es a consecuencia de la ausencia o presencia de ATM y no de su actividad quinasa, ya que en células en presencia de ATM y tratadas con los inhibidores no se veían afectados los niveles proteicos de NBS1. Recientemente, se ha demostrado la participación de ATM en la regulación de niveles proteicos, en este caso el silenciamiento de ATM conlleva a un incremento de los niveles de $\mathrm{p} 14^{\mathrm{ARF}}$ (Velimezi et al, 2013). Por lo tanto es factible pensar que ATM si podría estar afectando a los niveles proteicos de una proteína en particular, pero en esta ocasión el efecto sobre NBS1 es estrictamente relacionado con VRK1. En base a nuestros resultados, la pregunta era clara: ¿Cuál sería el mecanismo por el que se estarían regulando los niveles proteicos de NBS1? Pensamos en las dos formas principales en las que se podría estar mediando este efecto; tal vez mediante la regulación de la expresión del gen de NBS1 o quizás mediante la degradación de esta proteína. Así, lo primero que hicimos fue analizar mediante qRT-PCR los niveles de expresión de NBS1 en células deficientes de ATM a las que previamente se había tratado con un ARN de interferencia específico para VRK1. Los resultados no mostraban diferencias significativas en los niveles de ARN mensajero de NBS1 comparando con las células control, de tal forma que la primera hipótesis quedaba descartada. Por este motivo, pasamos a estudiar la posible degradación a nivel proteico de NBS1 en ausencia de las quinasas ATM y VRK1.

La mayoría de las proteínas citosólicas y nucleares son degradadas en el proteasoma (Bonifacino \& Weissman, 1998). Este sistema de degradación (ubiquitinaproteasoma) mantiene el balance de los niveles proteicos con el fin de regular la homeostasis celular y ayudar al control de procesos como el ciclo celular, la diferenciación, la apoptosis, la expresión génica o la reparación del ADN (Finley, 2009; Xie, 2010). La respuesta al daño en el ADN coordina el reclutamiento de proteínas, la parada del ciclo celular y la apoptosis en caso de que el daño sea severo y no pueda ser reparado. La mayoría de estos procesos son controlados por modificaciones post-traduccionales como fosforilaciones, ubiquitinaciones, acetilaciones, entre otras (Ciccia \& Elledge, 2010; Panier \& Durocher, 2013). Una vez 
las proteínas reclutadas a las DSBs han realizado su función y reparado el daño en el $A D N$, estas deben ser retiradas para desensamblar los focos. Por lo tanto, debe existir un mecanismo de post-reparación encargado de desensamblar, retirar y/o degradar las proteínas que participan en la reparación del ADN (Ramadan \& Meerang, 2011). El proceso de ubiquitinación en la respuesta al daño en el ADN es uno de los tópicos con muchas dudas por resolver (Lukas, 2010 ). Existen 7 residuos de lisina en la ubiquitina (K6, K11, K27, K29, K33, K48 y K63) y dependiendo del residuo que sea ubiquitinado se regulan procesos como la degradación, la interacción y la actividad enzimática de las proteínas. Por ejemplo, la formación de cadenas de poliubiquitinas en la lisina 48 unidas a una determinada proteína generalmente es señal para la degradación por el proteasoma, mientras que la monoubiquitinación o poliubiquitinación en la lisina 63 es importante para la localización celular de proteínas o para el reclutamiento en la reparación del ADN (Pickart \& Eddins, 2004). Se ha investigado mayormente la degradación por el proteasoma de proteínas que participan en las vías de reparación NER y BER (Bergink \& Jentsch, 2009), así como también la localización y reclutamiento de proteínas tras la poliubiquitinación en la lisina 63 en las DSBs (Panier \& Durocher, 2009). Sin embargo, poco se conoce sobre la degradación de proteínas que participan en la reparación de las DSBs. En la respuesta al daño en el ADN por DSBs, las proteínas 53BP1, MDC1, NBS1, TopBP1, ATRIP y claspina, son poliubiquitinadas formándose cadenas de ubiquitina K48 para su posterior degradación (Ramadan \& Meerang, 2011). Basados en la información anterior, quisimos observar si la disminución de los niveles de NBS1 como efecto del silenciamiento de VRK1 y la falta de ATM era consecuencia de la degradación de esta proteína. Detectamos mediante el uso del inhibidor del proteasoma MG132, el cual bloquea la actividad proteolítica del proteasoma 26S (Shirley et al, 2005) que el efecto sobre los niveles de NBS1 en la línea celular deficiente de ATM con bajos niveles de expresión de VRK1 se revertía. Este resultado fue confirmado al observar la acumulación de NBS1 en los focos de reparación tras el tratamiento con dicho inhibidor, revirtiendo el efecto producido por el silenciamiento de VRK1 y la deficiencia de ATM. Por lo tanto, en este trabajo, demostramos que VRK1 es necesaria para reclutar a NBS1 a los focos de reparación y que, además, ejerce un efecto protector al evitar la degradación de NBS1, posiblemente por un mecanismo dependiente de su actividad quinasa, evitando la ubiquitinación y posterior degradación a través de su fosforilación, el mecanismo anteriormente descrito se resume en la figura 75. Para confirmar que efectivamente el efecto en NBS1 es dependiente de la actividad quinasa de VRK1, se debería realizar un ensayo de rescate de fenotipo en el cual viéramos si la sobre-expresión de una quinasa VRK1 tanto silvestre como inactiva, resistente al ARN de interferencia, en células silenciadas para VRK1, rescatara la formación de los focos de NBS1. 

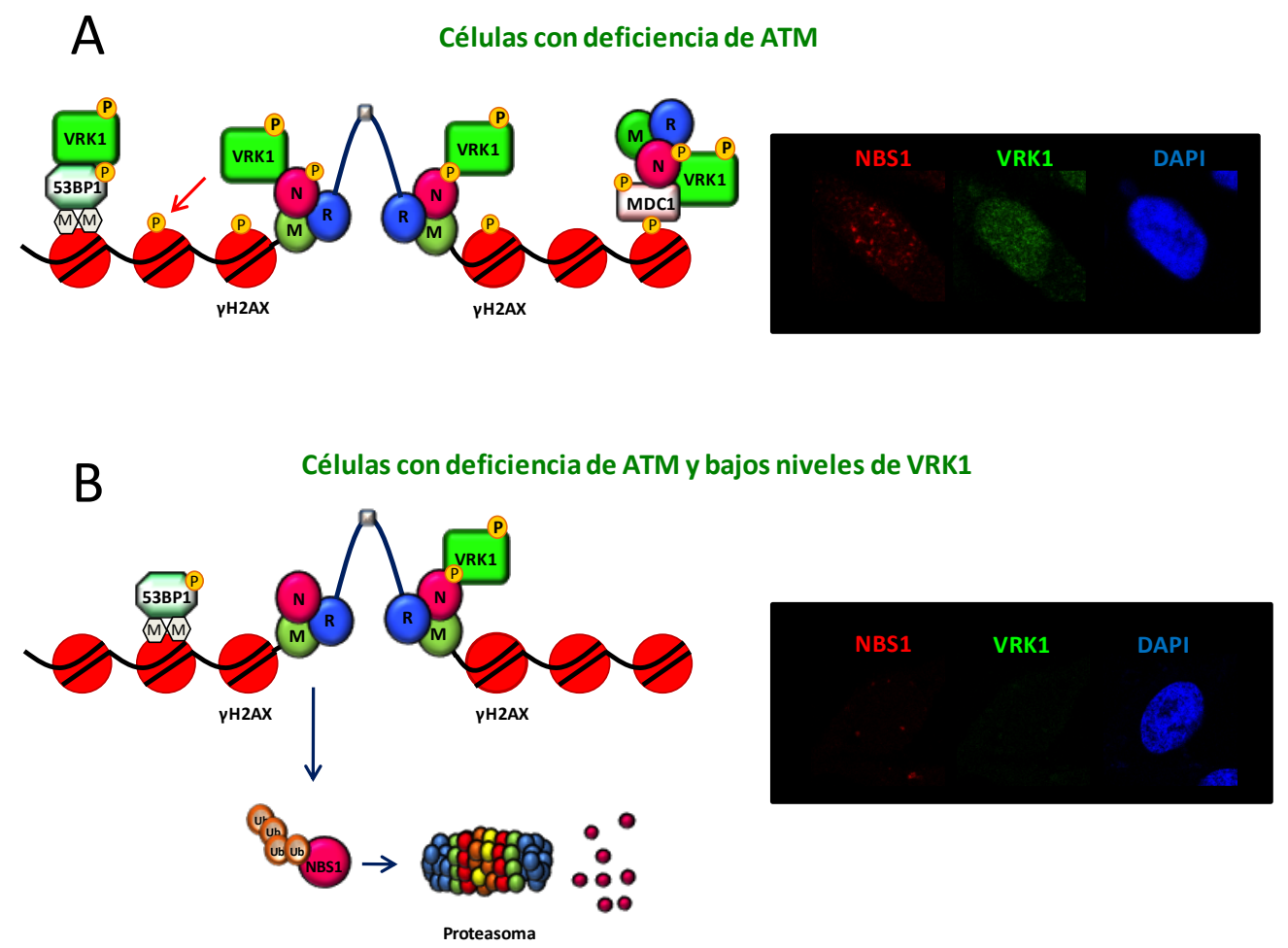

Figura 75. Esquema de la participación de VRK1 en la formación de focos de reparación en ausencia de ATM. A. VRK1 en ausencia de ATM media la fosforilación y formación de focos de NBS1. Sin embargo en la usencia de ambas quinasas (B), hipotetizamos que NBS1 puede ser ubiquitinada para su posterior degradación en el proteasoma, de forma tal que no se pueda reclutar a los puntos de ADN lesionado y por lo tanto no se repare el ADN correctamente. P: residuos fosforilados, $\mathrm{M}$ : residuos metilados, $\mathrm{Ub}$ : residuos ubiquitinados.

Para esclarecer cuál puede ser el mecanismo utilizado por VRK1 para evitar la degradación de NBS1, nos planteamos estudiar el efecto de la ubiquitina y dos E3 ubiquitina-ligasas: RNF8 y Mdm2. Alt y colaboradores han demostrado que Mdm2 puede obstaculizar la reparación de las DSBs a través de su interacción directa con NBS1 (Alt et al, 2005). Además es bien conocido que Mdm2 interacciona e inhibe la actividad transcripcional de p53, además de mediar su degradación (Chen et al, 1995; Moll \& Petrenko, 2003). Por otro lado, en la respuesta al daño en el ADN, las tres principales E3-ligasas son RNF8, RNF168 y BRCA1, las cuales cooperan en la formación de diferentes tipos de cadenas ubiquitinadas. RNF8, a través de su domino FHA, interacciona con MDC1 después de que esta es fosforilada por ATM. Por otra parte, su dominio RING, recluta la enzima de conjugación (E2) de la ubiquitina UBC13 para facilitar la poliuniquitinación de K63 sobre la histona H2AX, procesos que ayudan al reclutamiento de 53BP1 y BRCA1 a los sitios de lesión del 
ADN (Kolas et al, 2007). RNF8, además, puede mediar la poliubiquitinación de K48 sobre proteínas diana con ayuda de la proteína E2 UBCH8 como señal para la degradación en el proteasoma (Lok et al, 2012). En un estudio realizado por ChiSheng Lu y colaboradores en el año 2012, se muestra como NBS1 es ubiquitinada por acción de RNF8 en presencia de UBCH5C o UBC13, promoviendo su unión a las roturas de doble cadena, observándose además que ambas proteínas pueden interaccionar (Lu et al, 2012). En nuestro trabajo obtuvimos un efecto completamente diferente en células deficientes de ATM, puesto que observamos una disminución en los niveles de NBS1 al transfectar las células con RNF8, efecto no tan pronunciado con la ubiquitina-ligasa Mdm2. De este modo, podríamos pensar que, de alguna forma, RNF8 está mediando la ubiquitinación de NBS1 para su posterior degradación, siendo un efecto dependiente de la ausencia de VRK1 y ATM. No conocemos, sin embargo, el mecanismo o las condiciones por las que RNF8 ubiquitina a NBS1 y pueda formar cadenas de ubiquitina K48 (sin descartar otras lisinas que medien el mismo efecto, como K11) que dirijan la degradación de esta proteína. Ling Feng y Junjie Cheng describieron en su estudio que RNF8 ayudaba a retirar de los sitios de lesión y controlar los niveles de las proteínas de reparación de las DSBs Ku80 y Chk2 a través de su degradación dependiente de la vía proteosomal (Feng \& Chen, 2012). Basándonos en este estudio, podríamos dilucidar que NBS1 tiene distintos destinos de ubiquitinación, según las condiciones, siendo K63ubiquitinada para el incremento de su reclutamiento a los focos de reparación, pero también siendo enviada a degradación en el proteasoma por poliubiqutinación en K48 debido a la ausencia de VRK1 y ATM. Es necesario profundizar en el estudio de la ubiquitinación de NBS1 para entender qué tipos de cadenas de ubiquitinas son formadas por RNF8 en células deficientes de ATM y con bajos niveles de expresión de VRK1. Para ello, se podrían realizar ensayos de ubiquitinación con las ubiquitinas mutadas en los residuos $\mathrm{K} 48$ o $\mathrm{K63}$, lo cual nos daría una pista del proceso, al observar la pérdida de ubiquitinación por parte de alguno de los mutantes.

Todos estos datos sugieren que VRK1 participa directamente en el reclutamiento de NBS1 a través de la interacción directa y fosforilación de NBS1 y, de manera indirecta, evitando la degradación de NBS1 en células carentes de ATM. Puede ser que la fosforilación de NBS1 por ATM y/o VRK1 medie el reclutamiento de NBS1 con ayuda de RNF8 que, al ubiquitinar a MDC1, ayuda a la retroalimentación positiva para reclutar más cantidad de NBS1; además de que ubiquitina a NBS1 promoviendo su mantenimiento en el sitio de lesión (Lu et al, 2012). Sin embargo, al no estar presentes estrictamente las dos quinasas, ATM y VRK1, que fosforilan o interaccionan con NBS1, quizás se exponga un residuo de lisina con alta probabilidad de ser ubiquitinado por RNF8 pero que, en este caso, medie la degradación de la proteína; degradación que podría ser llevada a cabo por la vía UBCH8, la cuál es una de las más estudiadas en reparación al ADN ya que media la formación de cadenas poliubiquitinadas en K48 para la degradación de proteínas (Lok et al, 2012)(Figura 
76). Al plantearnos esta hipótesis, revisamos con un programa de predicción de sitios de ubiquitinación sobre una proteína particular (www.ubpred.com), la posibilidad y sitios de que NBS1 pudiera ser ubiquitinado, obteniendo 28 residuos con una mediana o alta fiabilidad. Además, fue de gran interés observar como las lisinas K334 y K351 de NBS1 tienen alta probabilidad de ser ubiquitinadas, dado que entre ellas se encuentra la serina 343, diana de VRK1. Así, podríamos especular que la fosforilación en este residuo y la región de interacción con VRK1 pudieran estar ocultando lisinas que, al no estar presente la quinasa, sean blancos de ubiquitinación para degradación. Además, en el caso de que la interacción entre NBS1 y VRK1 evite la ubiquitinación con fines de degradación, aún no conocemos el sitio exacto de interacción de NBS1 con VRK1 por lo que sería necesario realizar un mapeo de interacción con las regiones de NBS1 y revisar si hay lisinas en esta región.
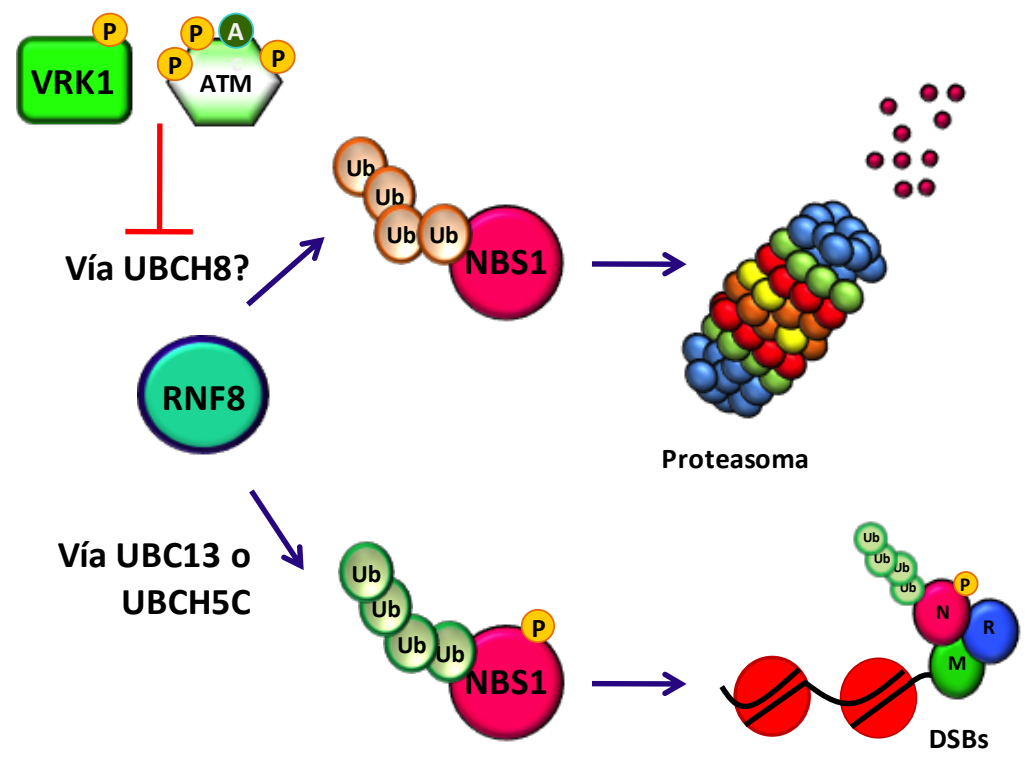

Ub) Cadenas ubiquitina K48

Ub) Cadenas ubiquitina $\mathrm{K} 63$

Figura 76. Modelo del posible mecanismo por el cual NBS1 está siendo degradado. NBS1 es ubiquitinada por RNF8 para la estabilización y mantenimiento de esta proteína en las DSBs. EI residuo K435 de NBS1 es clave para esta ubiquitinación mediada por UBC13 o UBCH5C (Lu et al, 2012). ATM y VRK1 protegen a NBS1 de la degradación, al no estar presentes ambas proteínas NBS1 es degradada por el proteasoma posiblemente por formación de cadenas de poliubiquitina a través de la lisina 48 , sin descartar otros posibles residuos de lisina que promuevan la misma función.

Por otro lado, inesperadamente, nos dimos cuenta de que los niveles de expresión de VRK1 disminuyeron de manera dosis dependiente al transfectar RNF8 en las 
células carentes de ATM. Esto nos hace pensar en la posibilidad de que VRK1 tenga una vía alternativa de degradación diferente a la lisosomal (Valbuena et al, 2011) en células deficientes de ATM. Sin embargo, en este trabajo, no hemos profundizado más en este efecto. Puesto que al parecer existe cierto efecto de RNF8 sobre VRK1, decidimos revisar si de alguna forma la ubiquitina-ligasa RNF8 podría afectar la interacción entre VRK1 y NBS1. Observamos la presencia de un complejo formado por las tres proteínas. Además, confirmamos la interacción entre VRK1 y RNF8, pero sin embargo, no podemos decir si esta interacción es directa o NBS1 está actuando como puente. Para ello sería necesario realizar estos experimentos silenciando NBS1 con un ARN de interferencia específico.

En la actualidad, la mayoría de los tratamientos utilizados para combatir el cáncer producen daño en el ADN. La acumulación de daño génico produce parada de ciclo y muerte celular (Helleday et al, 2008; Sanchez-Perez, 2006). Aunque en una primera etapa estos tratamientos son eficaces al controlar el crecimiento tumoral, se puede desarrollar resistencia con la posterior progresión de la enfermedad (Davidson et al, 2013). Esta resistencia es causada por el proceso de reparación del ADN que protege a las células del daño producido por radiación ionizante o fármacos quimioterapéuticos. Por lo tanto, el desarrollo de inhibidores de diferentes componentes de la respuesta al daño en el ADN pueda tener un gran potencial para la sensibilización de las células a los tratamientos, en particular aquellos tipos de cáncer más radio o quimioresistentes (Curtin, 2012; Martin, 2001). Se ha demostrado que células de cáncer de mama positivas para el receptor de estrógenos muestran altos niveles proteicos de VRK1, lo que puede contribuir a la resistencia de este tipo de tumores (Salzano et al, 2014). De tal manera, proponemos a VRK1 como una diana de inhibición ya que hemos demostrado que esta quinasa tiene un papel importante en la modulación de la respuesta al daño en el ADN a diferentes niveles en la vía de señalización, de tal forma que un tratamiento combinado puede ser una alternativa a producir lesiones sin que estas puedan ser reparadas, por ejemplo la inhibición de ATM con inhibidores específicos como KU55933 o CGK733, junto con el tratamiento con doxorubicina, incrementaron los niveles de apoptosis en células cancerosas (Khalil HS, 2012). 


\section{IMPLICACIÓN DE LA QUINASA HUMANA VRK2 EN LA RUTA DE LA APOPTOSIS}

\subsection{Expresión y localización subcelular de VRK2}

La apoptosis es un proceso complejo que a través de cambios morfológicos y reacciones bioquímicas produce la muerte celular de forma controlada. Este proceso juega un papel importante en el desarrollo, la homeostasis tisular y la eliminación de células dañadas. La no regulación de la apoptosis puede contribuir a patologías tales como enfermedades neurodegenerativas, desórdenes autoinmunes y cáncer (Elmore, 2007). Aunque hoy en día la apoptosis es uno de los procesos más estudiados, muchos componentes que modulan esta forma de muerte celular todavía son desconocidos.

La apoptosis es llevada a cabo por dos rutas principales: la ruta extrínseca y la ruta intrínseca, las cuales tienen como último fin la activación de proteínas que promoverán la muerte celular (Galluzzi et al, 2012). Existen múltiples mecanismos que regulan el proceso de la apoptosis, sin embargo se destacan dos por su relevancia, el primero, proteínas que pueden interaccionar con proteínas proapoptóticas o anti-apoptóticas, modulando su función, y el segundo, la regulación de la expresión de genes que codifican para proteínas pro-apoptóticas o antiapoptóticas, modificando sus niveles totales en la célula. En la activación de la ruta intrínseca de la apoptosis, se produce un cambio en la permeabilización de la membrana externa mitocondrial que conlleva a la liberación de proteínas proapoptóticas desde el espacio intermembranal hacia el citosol, induciendo la activación de caspasas efectoras y, de este modo, la apoptosis (Garcia-Saez, 2012; Tait \& Green, 2010). Es posible que existan otras proteínas que participen en la formación de complejos en la membrana mitocondrial, ayudando a modular la magnitud de la respuesta apoptótica, por tal motivo, en nuestro trabajo proponemos a VRK2 como una nueva proteína que puede intervenir en este proceso.

La quinasa humana VRK2 fue inicialmente descrita como una proteína de expresión ubicua (Nezu et al, 1997). Posteriormente, se distinguieron dos isoformas de esta quinasa, la isoforma VRK2A que presentaba expresión ubicua y la isoforma VRK2B la cual se expresaba en determinados tipos celulares (Blanco et al, 2006). En primer lugar, realizamos un panel de expresión de las isoformas de VRK2 en diferentes líneas celulares. Encontramos que la isoforma VRK2A se expresa en todas las líneas celulares estudiadas. No obstante, apreciamos grandes diferencias en los niveles de 
expresión de la isoforma VRK2B, donde las líneas celulares HeLa y MCF7 presentaron los mayores niveles de expresión, confirmando los resultados de Blanco y colaboradores (Blanco et al, 2006); sin embargo, aún no conocemos el significado de la relación entre los altos niveles de expresión de VRK2B con la línea celular, ni tampoco el mecanismo por el cual este efecto es regulado.

Las quinasas VRK1, VRK2A y VRK2B presentan diferente localización subcelular, característica importante en la regulación e interacción con diferentes proteínas, lo cual conlleva a que desempeñen diferentes funciones. Por tal motivo, estudiamos la localización de VRK2 mediante el uso de un anticuerpo específico de producción propia, anticuerpo que detecta indistintamente ambas isoformas de VRK2. Confirmamos que esta quinasa tiene distribución mayoritariamente citosólica, además de presentar una tinción tipo granular indicativa de su localización anclada a membranas, tal y como se ha descrito para la isoforma VRK2A, debido a la presencia de la región transmembrana hidrófobica en su región carboxi-terminal (Blanco et al, 2006; Nichols \& Traktman, 2004).

\subsection{VRK2A y su relación con la apoptosis}

Existen diferentes datos que nos sugieren que la quinasa VRK2A podría participar en la regulación de funciones celulares relacionadas con la mitocondria, específicamente la apoptosis. En el año 2006, Li y colaboradores demostraron la interacción entre VRK2A y la proteína del virus de Epstein-barr BHRF1 (homóloga de $\mathrm{Bcl}-2$ en mamíferos), teniendo un efecto de protección celular contra la apoptosis (Li et al, 2006). Por otro lado, ya conocemos que la mitocondria es el orgánulo principal para el desarrollo de la apoptosis por vía intrínseca (Ravagnan et al, 2002), y sabemos que existe una subpoblación de VRK2 en este lugar (Blanco et al, 2006). Finalmente, al realizar experimentos de silenciamiento de la expresión de VRK2 con un ARN de interferencia específico, veíamos frecuentemente el incremento de muerte celular. Basándonos en toda esta información, nos pareció de gran interés estudiar la implicación y posible modulación de la apoptosis por parte de la quinasa humana VRK2A.

Como primera aproximación al estudio del posible papel de VRK2 en la muerte celular programada, quisimos observar la localización de proteínas importantes en la modulación de la apoptosis, como son Bcl-xL y Bax, en comparación con VRK2. Para ello, realizamos inmunofluorescencias comprobando la co-localización entre VRK2 y dichas proteínas en células A549, concluyendo que se encuentran en el mismo compartimento celular. Posteriormente, estudiamos la posibilidad de que VRK2A pudiera interaccionar con diferentes miembros de la familia $\mathrm{Bcl}-2$, demostrando que VRK2A solo interacciona con Bcl-xL pero no con Bcl-2 o Bax. Por lo tanto, el efecto protector de VRK2A en la apoptosis posiblemente sea consecuencia de la interacción 
entre esta quinasa y la proteína anti-apoptótica $\mathrm{Bcl}-\mathrm{xL}$, efecto funcionalmente similar al ocurrido entre la interacción de VRK2A y la proteína del virus de Epstein-Barr, BHRF1 ( $L i$ et al, 2006). Se ha descrito que uno de los mecanismos propuestos de cómo $\mathrm{Bcl}-\mathrm{xL}$ y $\mathrm{Bcl}-2$ mantienen el balance apoptótico en la célula, es a través de la heterodimerización con miembros pro-apoptóticos como Bax y Bak (Billen et al, 2008; Minn et al, 1999). Estructuralmente, Bcl-xL tiene dos alfa hélices hidrófobicas en su región central rodeadas por cinco hélices anfipáticas (Muchmore et al, 1996). Se ha descrito que esta estructura favorece la inserción de esta proteína en la membrana mitocondrial, inhibiendo la respuesta apoptótica (Minn et al, 1999).Esta información nos hace pensar que posiblemente la inserción de $\mathrm{Bcl}-\mathrm{xL}$, favorecida tal vez por el anclaje de VRK2A en la membrana mitocondrial, produciría la heterodimerización de Bax con $\mathrm{Bcl}-\mathrm{XL}$, inhibiendo la formación del poro mitocondrial debido a la no oligomerización de Bax (Figura 77A, pág. 180). Esto se confirma con el hecho de que el silenciamiento de VRK2, modula la liberación del citocromo c al citosol, demostrando que la ausencia de esta quinasa permite la formación del poro mitocondrial activando la respuesta apoptótica.

No obstante, no descartamos algún posible efecto mediado por la actividad quinasa de VRK2A, ya que las fosforilaciones son cambios postraduccionales importantes en la apoptosis, puesto que ayudan a la activación o inhibición de proteínas que hacen parte de esta compleja red proteica (Niemi \& MacKeigan, 2013), en la cual se incluye a Bax entre sus componentes (Kim et al, 2006; Linseman et al, 2004). Por ejemplo, se conocen varias fosforilaciones importantes que modulan la respuesta a la apoptosis, entre las cuales destacamos la fosforilación de AKT sobre el residuo serina 184 de Bax, la cual inhibe el efecto de Bax sobre la mitocondria, al mantenerlo en el citoplasma interaccionando con miembros de la familia anti-apoptótica Bcl-2, previeniendo el desarrollo de la apoptosis (Gardai et al, 2004). En nuestro laboratorio se ha descrito que el silenciamiento o sobre-expresión de VRK2 no afecta a la activación de AKT (evidenciada por la fosforilación en su residuo serina 473) (Fernandez et al, 2010). Además, Bax también puede ser fosforilado por otras quinasas como JNK y/o p38 en la serina 167, fosforilación necesaria para la activación de Bax y su translocación a la membrana mitocondrial (Kim et al, 2006). Mediante la realización de ensayos quinasa in vitro hemos encontrado que VRK2A no fosforila a Bax, sin embargo es posible que VRK2A pueda fosforilar alguna proteína aún no conocida que interfiera con la translocación de Bax a la membrana mitocondrial (Figura 77B, pág. 180). Por ejemplo, la proteína HSP27 inhibe la activación, oligomerización y translocación de Bax a la mitocondria, reduciendo la liberación del citocromo c y, por ende, incrementando la supervivencia celular (Havasi et al, 2008). Se ha visto que esta proteína puede ser fosforilada mediando el efecto de protección sobre las células (Stetler et al, 2012). Por lo tanto, HSP27 tiene las características apropiadas para ser una buena candidata de estudio, proponiéndola como posible diana de regulación de VRK2. 
El equilibrio entre las proteínas pro-apoptóticas y anti-apoptóticas determinan el destino final de la célula (Deveraux et al, 2001). El silenciamiento de la expresión de VRK2 se traduce en un incremento de los niveles proteicos de Bax y en una disminución de los niveles proteicos de $\mathrm{Bcl}-2$ y $\mathrm{Bcl}-\mathrm{xL}$, alterando así el equilibrio entre estas proteínas, que conlleva a la activación de la apoptosis. Por lo tanto, concluimos que las variaciones de los niveles proteicos de VRK2, también afectan a los niveles de Bax. El tratamiento con los ARN de interferencia para VRK2 causa la disminución en sus niveles de ARN mensajero entre un $60-80 \%$ en todas las líneas celulares estudiadas. Sin embargo, la disminución de los niveles proteicos de VRK2 requiere tiempos más largos de tratamiento con los ARN de interferencia. Aunque cese la transcripción de las isoformas de esta quinasa, son proteínas muy estables y tardan varios días en degradarse debido a su larga vida media. Este es el principal motivo por el cual utilizamos las líneas celulares A549 y HeLa en nuestro trabajo, ya que en líneas celulares como MCF7 y 293T no se observó la disminución de los niveles proteicos incluso tras 96 horas post-transfección, sí viendo una reducción de los niveles de ARN mensajero. Por tal motivo pensamos que la estabilidad de VRK2A y VRK2B varía enormemente en función de la línea celular, tal vez por la regulación de algún tipo de mecanismo sobre su estabilidad.

Bax es esencial para completar el proceso de apoptosis (Lalier et al, 2007; Pawlowski \& Kraft, 2000); una vez es activado, se inserta en la membrana externa mitocondrial mediando la formación de poros, con la posterior liberación de citocromo c y otras proteínas pro-apoptóticas (Annis et al, 2005; Lalier et al, 2007). La primera vez que el promotor del gen de Bax fue clonado, se demostró que este respondía al factor de transcripción p53 (Miyashita \& Reed, 1995). Posteriormente, también se describió que el gen de Bax era activado por c-myc induciendo la apoptosis (Mitchell et al, 2000). En primer lugar, para revisar si la disminución de los niveles de expresión de VRK2 afectaba la expresión génica de $\mathrm{Bax}, \mathrm{Bcl}-\mathrm{xL}$ y $\mathrm{Bcl}-2$, realizamos ensayos de qRTPCR que nos permitieron verificar el incremento de los niveles de ARN mensajero de Bax en células con bajos niveles de VRK2, mientras que, los niveles de ARN mensajero de $\mathrm{Bcl}-\mathrm{xL}$ y $\mathrm{Bcl}-2$ no sufrieron cambios significativos. Además, en este trabajo demostramos que la supresión de la expresión de VRK2 estimulaba la activación transcripcional del promotor de Bax. Así, concluimos que VRK2 se comporta como un regulador negativo de Bax. En concordancia con los resultados anteriores, pudimos verificar que, efectivamente, VRK2A tenía un efecto de inhibición sobre Bax, ya que la activación del promotor de Bax con camptotecina fue inhibida con la sobre-expresión de VRK2A. Es muy probable que VRK2A esté controlando la activación génica de Bax a través de un mecanismo de supresión transcripcional mediado por alguna proteína aún no conocida, sin embargo, esta hipótesis debe ser estudiada más a fondo (Figura 77C). 


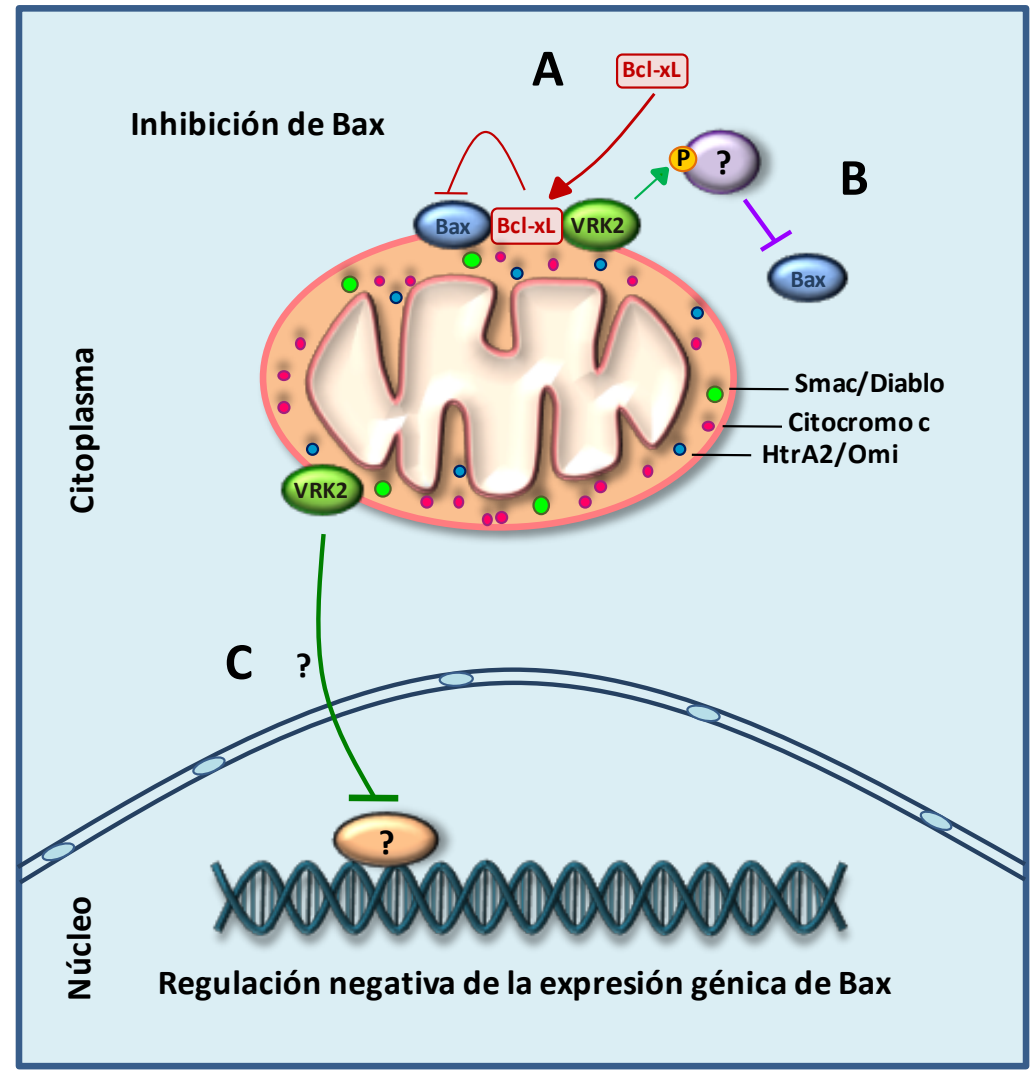

Figura 77. Mecanismos propuestos para la regulación negativa de Bax por VRK2A. A. VRK2A ayuda a la inserción de $\mathrm{Bcl}-\mathrm{xL}$ a la membrana mitocondrial, favoreciendo la heterodimerización de esta proteína con Bax, evitando así la formación del poro mitocondrial. B. VRK2A podría fosforilar una proteína en particular que evite la translocación de Bax a la membrana mitocondrial. C. VRK2A inhibe la expresión génica de Bax, efecto modulado por una proteína aún desconocida.

En nuestro trabajo hemos demostrado que VRK2A actúa de dos formas en la modulación de la respuesta celular de la apoptosis: a través de la interacción con proteínas como $\mathrm{Bcl}-\mathrm{xL}$ y en la regulación transcripcional de Bax. Este efecto de protección de VRK2A contra la apoptosis también podría ser influenciado por la participación de esta quinasa en otras vías de señalización. Por ejemplo, VRK2A interacciona con proteínas adaptadoras inhibiendo la transmisión de señales. Así, VRK2A interacciona con JIP (proteína adaptadora de JNK), inhibiendo la incorporación de JNK al complejo y provocando de este modo una disminución de su actividad que resulta en el bloqueo de la fosforilación de c-Jun (Blanco et al, 2007; Blanco et al, 2008). De esta forma, sería un mecanismo indirecto de protección, 
puesto que c-Jun activa el desarrollo de la apoptosis (Bossy-Wetzel et al, 1997; Dhanasekaran \& Reddy, 2008). Por otro lado, VRK2A también interacciona con la proteína adaptadora KSR1 boqueando la fosforilación de ERK, pero sin afectar a la activación de AKT; de esta manera aunque altere una de las vías relacionadas con proliferación, facilita la supervivencia celular (Fernandez et al, 2010).

A continuación, se evaluó la liberación del citocromo c y el procesamiento de PARP como consecuencia de la activación final de la apoptosis, mediado por el incremento de la expresión de Bax tras el silenciamiento de VRK2. La permeabilización de la membrana externa mitocondrial gracias a la formación del poro mitocondrial mediado por Bax y Bak (Dewson \& Kluck, 2009), permite el ingreso de agua y solutos del citosol hacia el espacio intermembranal, provocando la liberación de varias proteínas como el citocromo c, el cual interactúa con el monómero APAF-1, facilitando un cambio conformacional en esta proteína que ayuda a su oligomerización y posterior reclutamiento de la pro-caspasa 9 para formar el apoptosoma (Green, 2005; Jiang \& Wang, 2004). Por otro lado, la presencia del procesamiento de PARP-1 es considerado como un marcador de apoptosis. PARP-1 es procesado por las caspasas efectoras produciéndose el fragmento C-terminal de 89 kDa y el fragmento $\mathrm{N}$-terminal de $24 \mathrm{Kda}$ (Chaitanya et al, 2010). La activación de PARP-1 conlleva a la depleción de NAD+ y ayuda a la liberación de AIF del espacio intermembranal de las mitocondrias al citosol (Soldani \& Scovassi, 2002). Comprobamos que la carencia de la quinasa VRK2 provoca la liberación del citocromo $c$ al citosol y el procesamiento de PARP, lo cual nos permite confirmar, una vez más, que VRK2, específicamente la isoforma VRK2A, está implicada en el proceso de apoptosis.

\subsection{VRK2 protege a las células de la apoptosis}

VRK2A regula negativamente a Bax, protegiendo a las células de la apoptosis. En base a esta afirmación, nos resultaba muy interesante ver el efecto de un fármaco citotóxico utilizado para el tratamiento de diferentes tipos de cáncer como la camptotecina, que induce la apoptosis a través del daño en el ADN (Morris \& Geller, 1996; Traganos et al, 1996; Zhang et al, 2000). El efecto del silenciamiento de VRK2 probablemente sensibiliza a las células a cualquier tipo de estrés (entre ellos el tratamiento con camptotecina) al reducir la eficacia de Bcl-xL en la protección contra la apoptosis e incrementando los niveles de Bax. En el cáncer de mama, existe una correlación inversa entre los niveles de expresión proteica del receptor de membrana tirosina quinasa ErbB2 (marcador de mal pronóstico) y VRK2, es decir, los tumores ErbB2 positivos tienen bajos niveles de expresión de VRK2, presentando estos tumores una mayor sensibilidad a la quimioterapia. Por el contrario, los tumores de mama negativos para ErbB2 y positivos para el receptor de estrógenos 
(marcador de buen pronóstico), presentan altos niveles de VRK2 (Fernandez et al, 2010), siendo estos tumores más quimioresistentes (Rouzier et al, 2005).

En tumores, los altos niveles de VRK2 pueden tener un doble papel. Por un lado, pueden inhibir la señal mitogénica reduciendo el crecimiento del tumor, ya que se ha demostrado que VRK2A actúa como modulador negativo de la ruta de señalización ERK1/2 (Fernandez et al, 2010). Por otro lado, estos niveles de VRK2 pueden producir resistencia a las células haciéndolas insensibles a la apoptosis, contribuyendo de esta forma a la supervivencia de las células tumorales. Por lo tanto, el efecto final sería una consecuencia del balance entre las vías de señalización alternas y la fuerza de sus respectivas señales. De este modo, cabe la posibilidad de que los altos niveles de VRK2 puedan intervenir en la resistencia de los tumores a la quimioterapia.

La mayoría de funciones conocidas de VRK2 son mediadas por interacciones entre proteínas, independientemente de su actividad quinasa. Sin embargo, recientemente se ha demostrado la primera función de VRK2 como quinasa activa mediante la fosforilación de su sustrato NFAT (Vazquez-Cedeira \& Lazo, 2012). El desarrollo de inhibidores específicos de interacciones proteicas sería una buena alternativa para contrarrestar efectos como en el caso de la interacción entre VRK2A y $\mathrm{Bcl}-\mathrm{xL}$ que conlleva a un incremento del efecto protector de esta proteína antiapoptótica. Así, esta inhibición ayudaría a aumentar la sensibilidad de las células tumorales a la muerte inducida por fármacos quimioterapéuticos. Sin embargo, hay que tener en cuenta que este tipo de inhibición solo afectaría selectivamente a algunos efectos mediados directamente por interacciones, pero no a otros mediados por la propia proteína, como en el caso del incremento de la expresión de Bax tras la disminución de los niveles de VRK2. Por otro lado, el desarrollo de inhibidores de la actividad quinasa es un nuevo campo de estudio de gran interés, ya que las quinasas participan en la mayoría de procesos celulares, además, el desarrollo de un inhibidor específico de una determinada quinasa permitiría conocer en mayor profundidad las funciones biológicas desempeñadas por dicha quinasa (Anastassiadis et al, 2011). Las quinasas VRK1 y VRK2 tienen en su estructura un dominio catalítico característico que difiere de la mayoría de quinasas en varios residuos críticos, siendo, sin embargo, catalíticamente activas (Blanco et al, 2006; Manning et al, 2002; Nichols \& Traktman, 2004). Estas diferencias en las VRK con respecto a otras quinasas son importantes para el desarrollo de inhibidores específicos. Además, estudios en nuestro laboratorio han demostrado que las quinasas VRK1 y VRK2 presentan un bajo grado de unión a inhibidores de ATP desarrollados para otras quinasas, característica similar a otras quinasas que tienen estructuras con residuos de unión a ATP atípicos (Fedorov et al, 2007; Vazquez-Cedeira et al, 2011). Esto conlleva a una ventaja con respecto a otras quinasas, donde uno de los problemas más comunes es la inhibición cruzada (Knight et al, 2010; Zhang et al, 2009). El desarrollo de 
inhibidores específicos contra la quinasa VRK2 puede ser una óptima alternativa de ayuda en el tratamiento de diferentes tipos de cáncer, ya que incrementaría la sensibilidad de las células tumorales a la apoptosis inducida por fármacos citotóxicos. 


\section{CONCLUSIONES}

1. La quinasa humana VRK1 es rápidamente activada en respuesta a estímulos que producen daño genotóxico independientemente de su naturaleza.

2. VRK1 se sitúa en el ápice de la ruta de señalización encargada de reparar las roturas de doble cadena del ADN. Sin embargo, también participa a diferentes niveles de esta ruta modulando la correcta reparación del ADN lesionado.

3. VRK1 no interviene en la respuesta ni función de la proteína mediadora MDC1.

4. NBS1 interacciona con la quinasa VRK1 en ausencia o presencia de daño. Además, NBS1 se presenta como una nueva diana de fosforilación de VRK1.

5. VRK1 es necesaria para el correcto reclutamiento de NBS1 a los focos de reparación. Además, tiene un efecto de protección sobre NBS1 evitando su degradación en células deficientes de ATM.

6. La presencia de VRK1 y ATM es estrictamente necesaria para la estabilidad proteica de NBS1, evitando su posible degradación mediada por la ubiquitina-ligasa E3 RNF8.

7. La modulación de la respuesta de VRK1 a las roturas de doble cadena en el ADN es independiente de ATM.

8. VRK2A modula el proceso de la apoptosis por vía intrínseca a través de su interacción con la proteína anti-apoptótica Bcl-xL.

9. VRK2A regula negativamente la expresión de Bax, protegiendo a las células de la apoptosis.

10. Los bajos niveles de VRK2 incrementan la sensibilidad de las células a fármacos quimioterapéuticos como la camptotecina. 
BIBLIOGRAFÍA 

Abraham RT (2004) PI 3-kinase related kinases: 'big' players in stress-induced signaling pathways. DNA Repair 3: 883-887

Acharya U, Mallabiabarrena A, Acharya JK, Malhotra V (1998) Signaling via mitogenactivated protein kinase kinase (MEK1) is required for Golgi fragmentation during mitosis. Cell 92: 183-192

Aihara H, Nakagawa T, Yasui K, Ohta T, Hirose S, Dhomae N, Takio K, Kaneko M, Takeshima Y, Muramatsu M, Ito $T$ (2004) Nucleosomal histone kinase-1 phosphorylates H2A Thr 119 during mitosis in the early Drosophila embryo. Genes Dev 18: 877-888

Alt JR, Bouska A, Fernandez MR, Cerny RL, Xiao H, Eischen CM (2005) Mdm2 binds to $\mathrm{Nbs} 1$ at sites of DNA damage and regulates double strand break repair. J Biol Chem 280: $18771-18781$

Ametller E, Garcia-Recio S, Costamagna D, Mayordomo C, Fernandez-Nogueira P, Carbo N, Pastor-Arroyo EM, Gascon P, Almendro V (2010) Tumor promoting effects of CD95 signaling in chemoresistant cells. Mol Cancer 9: 1476-4598

Anastassiadis T, Deacon SW, Devarajan K, Ma H, Peterson JR (2011) Comprehensive assay of kinase catalytic activity reveals features of kinase inhibitor selectivity. Nat Biotechnol 29: 1039-1045

Andersen JS, Lam YW, Leung AK, Ong SE, Lyon CE, Lamond Al, Mann M (2005) Nucleolar proteome dynamics. Nature 433: 77-83

Anderson L, Henderson C, Adachi Y (2001) Phosphorylation and rapid relocalization of 53BP1 to nuclear foci upon DNA damage. Mol Cell Biol 21: 1719-1729

Annis MG, Soucie EL, Dlugosz PJ, Cruz-Aguado JA, Penn LZ, Leber B, Andrews DW (2005) Bax forms multispanning monomers that oligomerize to permeabilize membranes during apoptosis. EMBO J 24: 2096-2103

Antoni L, Sodha N, Collins I, Garrett MD (2007) CHK2 kinase: cancer susceptibility and cancer therapy - two sides of the same coin? Nat Rev Cancer 7: 925-936

Antoniali G, Lirussi L, Poletto M, Tell G (2014) Emerging Roles of the Nucleolus in Regulating the DNA Damage Response: The Noncanonical DNA Repair Enzyme APE1/Ref-1 as a Paradigmatical Example. Antioxid Redox Signal 20: 621-639

Arthur JS (2008) MSK activation and physiological roles. Front Biosci 13: 5866-5879

Ashkenazi A, Dixit VM (1998) Death receptors: signaling and modulation. Science 281: $1305-1308$ 
Ashman K, Villar EL (2009) Phosphoproteomics and cancer research. Clin Transl Oncol 11: 356-362

Assenmacher N, Hopfner KP (2004) MRE11/RAD50/NBS1: complex activities. Chromosoma 113: 157-166

Baek SH (2011) When signaling kinases meet histones and histone modifiers in the nucleus. Mol Cell 42: 274-284

Bakkenist CJ, Kastan MB (2003) DNA damage activates ATM through intermolecular autophosphorylation and dimer dissociation. Nature 421: 499-506

Banin S, Moyal L, Shieh S, Taya Y, Anderson CW, Chessa L, Smorodinsky NI, Prives C, Reiss Y, Shiloh Y, Ziv Y (1998) Enhanced phosphorylation of p53 by ATM in response to DNA damage. Science 281: 1674-1677

Barakat K, Gajewski M, Tuszynski JA (2012) DNA repair inhibitors: the next major step to improve cancer therapy. Curr Top Med Chem 12: 1376-1390

Barcia-Sanjurjo I, Vazquez-Cedeira M, Barcia R, Lazo PA (2013) Sensitivity of the kinase activity of human vaccinia-related kinase proteins to toxic metals. J Biol Inorg Chem 18: 473-482

Barcia R, Lopez-Borges S, Vega FM, Lazo PA (2002) Kinetic properties of p53 phosphorylation by the human vaccinia-related kinase 1. Arch Biochem Biophys 399: 1-5

Bartocci C, Denchi EL (2013) Put a RING on it: regulation and inhibition of RNF8 and RNF168 RING finger E3 ligases at DNA damage sites. Front Genet 4: 00128

Basanez G, Sharpe JC, Galanis J, Brandt TB, Hardwick JM, Zimmerberg J (2002) Baxtype apoptotic proteins porate pure lipid bilayers through a mechanism sensitive to intrinsic monolayer curvature. J Biol Chem 277: 49360-49365

Baskar R, Lee KA, Yeo R, Yeoh KW (2012) Cancer and radiation therapy: current advances and future directions. Int J Med Sci 9: 193-199

Bekker-Jensen S, Lukas C, Kitagawa R, Melander F, Kastan MB, Bartek J, Lukas J (2006) Spatial organization of the mammalian genome surveillance machinery in response to DNA strand breaks. J Cell Biol 173: 195-206

Bekker-Jensen S, Lukas C, Melander F, Bartek J, Lukas J (2005) Dynamic assembly and sustained retention of 53BP1 at the sites of DNA damage are controlled by Mdc1/NFBD1. J Cell Biol 170: 201-211

Bekker-Jensen S, Mailand N (2010) Assembly and function of DNA double-strand break repair foci in mammalian cells. DNA Repair (Amst) 9: 1219-1228 
Bekker-Jensen S, Mailand N (2011) The ubiquitin- and SUMO-dependent signaling response to DNA double-strand breaks. FEBS Lett 585: 2914-2919

Berger SL (2007) The complex language of chromatin regulation during transcription. Nature 447: 407-412

Bergink S, Jentsch S (2009) Principles of ubiquitin and SUMO modifications in DNA repair. Nature 458: 461-467

Bhoumik A, Ronai Z (2008) ATF2: a transcription factor that elicits oncogenic or tumor suppressor activities. Cell Cycle 7: 2341-2345

Billen LP, Kokoski CL, Lovell JF, Leber B, Andrews DW (2008) Bcl-XL inhibits membrane permeabilization by competing with Bax. PLoS Biol 6: 0060147

Birnboim HC, Doly J (1979) A rapid alkaline extraction procedure for screening recombinant plasmid DNA. Nucleic Acids Res 7: 1513-1523

Blanco S, Klimcakova L, Vega FM, Lazo PA (2006) The subcellular localization of vaccinia-related kinase-2 (VRK2) isoforms determines their different effect on p53 stability in tumour cell lines. FEBS J 273: 2487-2504

Blanco S, Santos C, Lazo PA (2007) Vaccinia-related kinase 2 modulates the stress response to hypoxia mediated by TAK1. Mol Cell Biol 27: 7273-7283

Blanco S, Sanz-Garcia M, Santos CR, Lazo PA (2008) Modulation of interleukin-1 transcriptional response by the interaction between VRK2 and the JIP1 scaffold protein. PLoS One 3: 0001660

Bleicken S, Classen M, Padmavathi PV, Ishikawa T, Zeth K, Steinhoff HJ, Bordignon E (2010) Molecular details of Bax activation, oligomerization, and membrane insertion. J Biol Chem 285: 6636-6647

Bonifacino JS, Weissman AM (1998) Ubiquitin and the control of protein fate in the secretory and endocytic pathways. Annu Rev Cell Dev Biol 14: 19-57

Bossy-Wetzel E, Bakiri L, Yaniv M (1997) Induction of apoptosis by the transcription factor c-Jun. EMBO J 16: 1695-1709

Botuyan MV, Lee J, Ward IM, Kim JE, Thompson JR, Chen J, Mer G (2006) Structural basis for the methylation state-specific recognition of histone H4-K20 by 53BP1 and Crb2 in DNA repair. Cell 127: 1361-1373

Boudeau J, Miranda-Saavedra D, Barton GJ, Alessi DR (2006) Emerging roles of pseudokinases. Trends Cell Biol 16: 443-452

Boulon S, Westman BJ, Hutten S, Boisvert FM, Lamond AI (2010) The nucleolus under stress. Mol Cell 40: 216-227 
Boyle KA, Traktman P (2004) Members of a novel family of mammalian protein kinases complement the DNA-negative phenotype of a vaccinia virus ts mutant defective in the B1 kinase. J Virol 78: 1992-2005

Bratton SB, Salvesen GS (2010) Regulation of the Apaf-1-caspase-9 apoptosome. J Cell Sci 123: 3209-3214

Burma S, Chen BP, Murphy M, Kurimasa A, Chen DJ (2001) ATM phosphorylates histone $\mathrm{H} 2 \mathrm{AX}$ in response to DNA double-strand breaks. $J$ Biol Chem 276: 4246242467

Caestecker KW, Van de Walle GR (2013) The role of BRCA1 in DNA double-strand repair: past and present. Exp Cell Res 319: 575-587

Cai Z, Chehab NH, Pavletich NP (2009) Structure and activation mechanism of the CHK2 DNA damage checkpoint kinase. Mol Cell 35: 818-829

Cargnello M, Roux PP (2011) Activation and function of the MAPKs and their substrates, the MAPK-activated protein kinases. Microbiol Mol Biol Rev 75: 50-83

Cerosaletti KM, Concannon P (2003) Nibrin forkhead-associated domain and breast cancer C-terminal domain are both required for nuclear focus formation and phosphorylation. J Biol Chem 278: 21944-21951

Ciccia A, Elledge SJ (2010) The DNA damage response: making it safe to play with knives. Mol Cell 40: 179-204

Cimprich KA, Cortez D (2008) ATR: an essential regulator of genome integrity. Nat Rev Mol Cell Biol 9: 616-627

Cole F, Keeney S, Jasin M (2010) Evolutionary conservation of meiotic DSB proteins: more than just Spo11. Genes Dev 24: 1201-1207

Cook PJ, Ju BG, Telese F, Wang X, Glass CK, Rosenfeld MG (2009) Tyrosine dephosphorylation of $\mathrm{H} 2 \mathrm{AX}$ modulates apoptosis and survival decisions. Nature 458: 591-596

Cooke MS, Evans MD, Dizdaroglu M, Lunec J (2003) Oxidative DNA damage: mechanisms, mutation, and disease. FASEB J 17: 1195-1214

Cory S, Adams JM (2002) The Bcl2 family: regulators of the cellular life-or-death switch. Nat Rev Cancer 2: 647-656

Costelloe T, Fitzgerald J, Murphy NJ, Flaus A, Lowndes NF (2006) Chromatin modulation and the DNA damage response. Exp Cell Res 312: 2677-2686 
Coster G, Goldberg M (2010) The cellular response to DNA damage: a focus on MDC1 and its interacting proteins. Nucleus 1: 166-178

Cromie GA, Connelly JC, Leach DR (2001) Recombination at double-strand breaks and DNA ends: conserved mechanisms from phage to humans. Mol Cell 8: 1163-1174

Curtin NJ (2012) DNA repair dysregulation from cancer driver to therapeutic target. Nat Rev Cancer 12: 801-817

Czornak K, Chughtai S, Chrzanowska KH (2008) Mystery of DNA repair: the role of the MRN complex and ATM kinase in DNA damage repair. J Appl Genet 49: 383-396

Chai J, Du C, Wu JW, Kyin S, Wang X, Shi Y (2000) Structural and biochemical basis of apoptotic activation by Smac/DIABLO. Nature 406: 855-862

Chaitanya GV, Steven AJ, Babu PP (2010) PARP-1 cleavage fragments: signatures of cell-death proteases in neurodegeneration. Cell Commun Signal 8: 8-31

Chandler KE, Del Rio A, Rakshi K, Springell K, Williams DK, Stoodley N, Woods CG, Pilz DT (2006) Leucodysplasia, microcephaly, cerebral malformation (LMC): a novel recessive disorder linked to 2p16. Brain 129: 272-277

Chang L, Karin M (2001) Mammalian MAP kinase signalling cascades. Nature 410: 3740

Chapman JR, Jackson SP (2008) Phospho-dependent interactions between NBS1 and MDC1 mediate chromatin retention of the MRN complex at sites of DNA damage. EMBO Rep 9: 795-801

Chaudhuri J, Basu U, Zarrin A, Yan C, Franco S, Perlot T, Vuong B, Wang J, Phan RT, Datta A, Manis J, Alt FW (2007) Evolution of the immunoglobulin heavy chain class switch recombination mechanism. Adv Immunol 94: 157-214

Chen J, Lin J, Levine AJ (1995) Regulation of transcription functions of the p53 tumor suppressor by the mdm-2 oncogene. Mol Med 1: 142-152

Chen L, Nievera CJ, Lee AY, Wu X (2008) Cell cycle-dependent complex formation of BRCA1.CtIP.MRN is important for DNA double-strand break repair. J Biol Chem 283: $7713-7720$

Choi YH, Park CH, Kim W, Ling H, Kang A, Chang MW, Im SK, Jeong HW, Kong YY, Kim KT (2010) Vaccinia-related kinase 1 is required for the maintenance of undifferentiated spermatogonia in mouse male germ cells. PLoS One 5: 0015254

Chowdhury D, Keogh MC, Ishii H, Peterson CL, Buratowski S, Lieberman J (2005) gamma-H2AX dephosphorylation by protein phosphatase $2 \mathrm{~A}$ facilitates DNA doublestrand break repair. Mol Cell 20: 801-809 
d'Adda di Fagagna $\mathrm{F}$ (2008) Living on a break: cellular senescence as a DNA-damage response. Nat Rev Cancer 8: 512-522

Dai J, Sultan S, Taylor SS, Higgins JM (2005) The kinase haspin is required for mitotic histone $\mathrm{H} 3 \mathrm{Thr} 3$ phosphorylation and normal metaphase chromosome alignment. Genes Dev 19: 472-488

Darding M, Meier P (2012) IAPs: guardians of RIPK1. Cell Death Differ 19: 58-66

Davidson D, Amrein L, Panasci L, Aloyz R (2013) Small Molecules, Inhibitors of DNAPK, Targeting DNA Repair, and Beyond. Front Pharmacol 4

de Jager M, van Noort J, van Gent DC, Dekker C, Kanaar R, Wyman C (2001) Human Rad50/Mre11 is a flexible complex that can tether DNA ends. Mol Cell 8: 1129-1135

Deak M, Clifton AD, Lucocq LM, Alessi DR (1998) Mitogen- and stress-activated protein kinase-1 (MSK1) is directly activated by MAPK and SAPK2/p38, and may mediate activation of CREB. EMBO J 17: 4426-4441

Deng CX (2006) BRCA1: cell cycle checkpoint, genetic instability, DNA damage response and cancer evolution. Nucleic Acids Res 34: 1416-1426

Deng CX, Wang RH (2003) Roles of BRCA1 in DNA damage repair: a link between development and cancer. Hum Mol Genet: R113-123

Deng Z, Sui G, Rosa PM, Zhao W (2012) Radiation-induced c-Jun activation depends on MEK1-ERK1/2 signaling pathway in microglial cells. PLoS One 7: 14

Derheimer FA, Kastan MB (2010) Multiple roles of ATM in monitoring and maintaining DNA integrity. FEBS Lett 584: 3675-3681

Desai-Mehta A, Cerosaletti KM, Concannon P (2001) Distinct functional domains of nibrin mediate Mre11 binding, focus formation, and nuclear localization. Mol Cell Biol 21: 2184-2191

Devarajan E, Sahin AA, Chen JS, Krishnamurthy RR, Aggarwal N, Brun AM, Sapino A, Zhang F, Sharma D, Yang XH, Tora AD, Mehta K (2002) Down-regulation of caspase 3 in breast cancer: a possible mechanism for chemoresistance. Oncogene 21: 88438851

Deveraux QL, Schendel SL, Reed JC (2001) Antiapoptotic proteins. The bcl-2 and inhibitor of apoptosis protein families. Cardiol Clin 19: 57-74

Dewson G, Kluck RM (2009) Mechanisms by which Bak and Bax permeabilise mitochondria during apoptosis. J Cell Sci 122: 2801-2808

Dhanasekaran DN, Reddy EP (2008) JNK signaling in apoptosis. Oncogene 27: 62456251 
Dhillon N, Hoekstra MF (1994) Characterization of two protein kinases from Schizosaccharomyces pombe involved in the regulation of DNA repair. $E M B O J \mathbf{1 3}$ : 2777-2788

Difilippantonio S, Celeste A, Kruhlak MJ, Lee Y, Difilippantonio MJ, Feigenbaum L, Jackson SP, McKinnon PJ, Nussenzweig A (2007) Distinct domains in Nbs1 regulate irradiation-induced checkpoints and apoptosis. J Exp Med 204: 1003-1011

Difilippantonio S, Nussenzweig A (2007) The NBS1-ATM connection revisited. Cell Cycle 6: 2366-2370

Durocher D, Taylor IA, Sarbassova D, Haire LF, Westcott SL, Jackson SP, Smerdon SJ, Yaffe MB (2000) The molecular basis of FHA domain:phosphopeptide binding specificity and implications for phospho-dependent signaling mechanisms. Mol Cell 6: $1169-1182$

Efeyan A, Serrano M (2007) p53: guardian of the genome and policeman of the oncogenes. Cell Cycle 6: 1006-1010

Eliezer Y, Argaman L, Rhie A, Doherty AJ, Goldberg M (2009) The direct interaction between 53BP1 and MDC1 is required for the recruitment of 53BP1 to sites of damage. J Biol Chem 284: 426-435

Elmore S (2007) Apoptosis: a review of programmed cell death. Toxicol Pathol 35: 495-516

Fackenthal JD, Olopade OI (2007) Breast cancer risk associated with BRCA1 and BRCA2 in diverse populations. Nat Rev Cancer 7: 937-948

Falck J, Coates J, Jackson SP (2005) Conserved modes of recruitment of ATM, ATR and DNA-PKcs to sites of DNA damage. Nature 434: 605-611

Falck J, Forment JV, Coates J, Mistrik M, Lukas J, Bartek J, Jackson SP (2012) CDK targeting of NBS1 promotes DNA-end resection, replication restart and homologous recombination. $E M B O$ Rep 13: 561-568

Falck J, Mailand N, Syljuasen RG, Bartek J, Lukas J (2001) The ATM-Chk2-Cdc25A checkpoint pathway guards against radioresistant DNA synthesis. Nature 410: 842847

Fedorov O, Marsden B, Pogacic V, Rellos P, Muller S, Bullock AN, Schwaller J, Sundstrom M, Knapp S (2007) A systematic interaction map of validated kinase inhibitors with Ser/Thr kinases. Proc Natl Acad Sci U S A 104: 20523-20528

Feng L, Chen J (2012) The E3 ligase RNF8 regulates KU80 removal and NHEJ repair. Nat Struct Mol Biol 19: 201-206 
Ferguson DO, Alt FW (2001) DNA double strand break repair and chromosomal translocation: lessons from animal models. Oncogene 20: 5572-5579

Fernandez IF, Blanco S, Lozano J, Lazo PA (2010) VRK2 inhibits mitogen-activated protein kinase signaling and inversely correlates with ErbB2 in human breast cancer. Mol Cell Biol 30: 4687-4697

Fernandez IF, Perez-Rivas LG, Blanco S, Castillo-Dominguez AA, Lozano J, Lazo PA (2012) VRK2 anchors KSR1-MEK1 to endoplasmic reticulum forming a macromolecular complex that compartmentalizes MAPK signaling. Cell Mol Life Sci 69: 3881-3893

Ferreon JC, Lee CW, Arai M, Martinez-Yamout MA, Dyson HJ, Wright PE (2009) Cooperative regulation of $\mathrm{p} 53$ by modulation of ternary complex formation with CBP/p300 and HDM2. Proc Natl Acad Sci U S A 106: 6591-6596

Finetti P, Cervera N, Charafe-Jauffret E, Chabannon C, Charpin C, Chaffanet $M$, Jacquemier J, Viens P, Birnbaum D, Bertucci F (2008) Sixteen-kinase gene expression identifies luminal breast cancers with poor prognosis. Cancer Res 68: 767-776

Finley D (2009) Recognition and processing of ubiquitin-protein conjugates by the proteasome. Annu Rev Biochem 78: 477-513

Fong PY, Xue WC, Ngan HY, Chiu PM, Chan KY, Tsao SW, Cheung AN (2006) Caspase activity is downregulated in choriocarcinoma: a cDNA array differential expression study. J Clin Pathol 59: 179-183

Fournier MV, Martin KJ, Kenny PA, Xhaja K, Bosch I, Yaswen P, Bissell MJ (2006) Gene expression signature in organized and growth-arrested mammary acini predicts good outcome in breast cancer. Cancer Res 66: 7095-7102

Fuentes-Prior P, Salvesen GS (2004) The protein structures that shape caspase activity, specificity, activation and inhibition. Biochem J 384: 201-232

Galluzzi L, Vitale I, Abrams JM, Alnemri ES, Baehrecke EH, Blagosklonny MV, Dawson TM, Dawson VL, El-Deiry WS, Fulda S, Gottlieb E, Green DR, Hengartner MO, Kepp O, Knight RA, Kumar S, Lipton SA, Lu X, Madeo F, Malorni W, Mehlen P, Nunez G, Peter ME, Piacentini M, Rubinsztein DC, Shi Y, Simon HU, Vandenabeele $P$, White E, Yuan J, Zhivotovsky B, Melino G, Kroemer G (2012) Molecular definitions of cell death subroutines: recommendations of the Nomenclature Committee on Cell Death 2012. Cell Death Differ 19: 107-120

Garcia-Saez AJ (2012) The secrets of the Bcl-2 family. Cell Death Differ 19: 1733-1740

Gardai SJ, Hildeman DA, Frankel SK, Whitlock BB, Frasch SC, Borregaard N, Marrack P, Bratton DL, Henson PM (2004) Phosphorylation of Bax Ser184 by Akt regulates its activity and apoptosis in neutrophils. J Biol Chem 279: 21085-21095 
Gatei M, Young D, Cerosaletti KM, Desai-Mehta A, Spring K, Kozlov S, Lavin MF, Gatti RA, Concannon P, Khanna K (2000) ATM-dependent phosphorylation of nibrin in response to radiation exposure. Nat Genet 25: 115-119

Gavathiotis E, Suzuki M, Davis ML, Pitter K, Bird GH, Katz SG, Tu HC, Kim H, Cheng EH, Tjandra N, Walensky LD (2008) BAX activation is initiated at a novel interaction site. Nature 455: 1076-1081

Gewirtz DA (1999) A critical evaluation of the mechanisms of action proposed for the antitumor effects of the anthracycline antibiotics adriamycin and daunorubicin. Biochem Pharmacol 57: 727-741

Goldberg M, Stucki M, Falck J, D'Amours D, Rahman D, Pappin D, Bartek J, Jackson SP (2003) MDC1 is required for the intra-S-phase DNA damage checkpoint. Nature 421: 952-956

Goodarzi AA, Yu Y, Riballo E, Douglas P, Walker SA, Ye R, Harer C, Marchetti C, Morrice N, Jeggo PA, Lees-Miller SP (2006) DNA-PK autophosphorylation facilitates Artemis endonuclease activity. EMBO J 25: 3880-3889

Gorgoulis VG, Vassiliou LV, Karakaidos $P$, Zacharatos $P$, Kotsinas A, Liloglou T, Venere M, Ditullio RA, Jr., Kastrinakis NG, Levy B, Kletsas D, Yoneta A, Herlyn M, Kittas C, Halazonetis TD (2005) Activation of the DNA damage checkpoint and genomic instability in human precancerous lesions. Nature 434: 907-913

Gorjanacz M, Klerkx EP, Galy V, Santarella R, Lopez-Iglesias C, Askjaer P, Mattaj IW (2007) Caenorhabditis elegans BAF-1 and its kinase VRK-1 participate directly in postmitotic nuclear envelope assembly. EMBO J 26: 132-143

Green DR (2005) Apoptotic pathways: ten minutes to dead. Cell 121: 671-674

Green DR, Evan GI (2002) A matter of life and death. Cancer Cell 1: 19-30

Guermah M, Palhan VB, Tackett AJ, Chait BT, Roeder RG (2006) Synergistic functions of $\mathrm{SII}$ and $\mathrm{p} 300$ in productive activator-dependent transcription of chromatin templates. Cell 125: 275-286

Hacker G (2000) The morphology of apoptosis. Cell Tissue Res 301: 5-17

Hanks SK, Hunter T (1995) Protein kinases 6. The eukaryotic protein kinase superfamily: kinase (catalytic) domain structure and classification. FASEB J 9: 576596

Happo L, Strasser A, Cory S (2012) BH3-only proteins in apoptosis at a glance. J Cell Sci 125: 1081-1087 
Haraguchi T, Koujin T, Segura-Totten M, Lee KK, Matsuoka $Y$, Yoneda $Y$, Wilson KL, Hiraoka $Y$ (2001) BAF is required for emerin assembly into the reforming nuclear envelope. J Cell Sci 114: 4575-4585

Harper JW, Elledge SJ (2007) The DNA damage response: ten years after. Mol Cell 28: 739-745

Havasi A, Li Z, Wang Z, Martin JL, Botla V, Ruchalski K, Schwartz JH, Borkan SC (2008) Hsp27 inhibits Bax activation and apoptosis via a phosphatidylinositol 3-kinasedependent mechanism. J Biol Chem 283: 12305-12313

Heikkinen K, Karppinen SM, Soini Y, Makinen M, Winqvist R (2003) Mutation screening of Mre11 complex genes: indication of RAD50 involvement in breast and ovarian cancer susceptibility. J Med Genet 40: e131

Helleday T, Lo J, van Gent DC, Engelward BP (2007) DNA double-strand break repair: from mechanistic understanding to cancer treatment. DNA Repair 6: 923-935

Helleday T, Petermann E, Lundin C, Hodgson B, Sharma RA (2008) DNA repair pathways as targets for cancer therapy. Nat Rev Cancer 8: 193-204

Hengartner MO (2000) The biochemistry of apoptosis. Nature 407: 770-776

Heyer WD, Ehmsen KT, Liu J (2010) Regulation of homologous recombination in eukaryotes. Annu Rev Genet 44: 113-139

Hickson I, Zhao Y, Richardson CJ, Green SJ, Martin NM, Orr Al, Reaper PM, Jackson SP, Curtin NJ, Smith GC (2004) Identification and characterization of a novel and specific inhibitor of the ataxia-telangiectasia mutated kinase ATM. Cancer Res 64: 9152-9159

Hill MM, Adrain C, Duriez PJ, Creagh EM, Martin SJ (2004) Analysis of the composition, assembly kinetics and activity of native Apaf-1 apoptosomes. EMBO J 23: $2134-2145$

Hirao A, Kong YY, Matsuoka S, Wakeham A, Ruland J, Yoshida H, Liu D, Elledge SJ, Mak TW (2000) DNA damage-induced activation of p53 by the checkpoint kinase Chk2. Science 287: 1824-1827

Ho Y, Mason S, Kobayashi R, Hoekstra M, Andrews B (1997) Role of the casein kinase $\mathrm{I}$ isoform, Hrr25, and the cell cycle-regulatory transcription factor, SBF, in the transcriptional response to DNA damage in Saccharomyces cerevisiae. Proc Natl Acad Sci U S A 94: 581-586

Hoeijmakers JH (2001) Genome maintenance mechanisms for preventing cancer. Nature 411: 366-374

Hoeijmakers JH (2009) DNA damage, aging, and cancer. N Engl J Med 361: 1475-1485 
Hopfner KP, Craig L, Moncalian G, Zinkel RA, Usui T, Owen BA, Karcher A, Henderson B, Bodmer JL, McMurray CT, Carney JP, Petrini JH, Tainer JA (2002) The Rad50 zinchook is a structure joining Mre11 complexes in DNA recombination and repair. Nature 418: 562-566

Horejsi Z, Falck J, Bakkenist CJ, Kastan MB, Lukas J, Bartek J (2004) Distinct functional domains of $\mathrm{Nbs} 1$ modulate the timing and magnitude of ATM activation after low doses of ionizing radiation. Oncogene 23: 3122-3127

Huang X, Traganos F, Darzynkiewicz Z (2003) DNA damage induced by DNA topoisomerase I- and topoisomerase II-inhibitors detected by histone H2AX phosphorylation in relation to the cell cycle phase and apoptosis. Cell Cycle 2: 614619

Huen MS, Chen J (2008) The DNA damage response pathways: at the crossroad of protein modifications. Cell Res 18: 8-16

Huyen Y, Zgheib O, Ditullio RA, Jr., Gorgoulis VG, Zacharatos P, Petty TJ, Sheston EA, Mellert HS, Stavridi ES, Halazonetis TD (2004) Methylated lysine 79 of histone H3 targets 53BP1 to DNA double-strand breaks. Nature 432: 406-411

Igney FH, Krammer PH (2002) Death and anti-death: tumour resistance to apoptosis. Nat Rev Cancer 2: 277-288

lijima K, Ohara M, Seki R, Tauchi H (2008) Dancing on damaged chromatin: functions of ATM and the RAD50/MRE11/NBS1 complex in cellular responses to DNA damage. J Radiat Res 49: 451-464

Iwabuchi K, Bartel PL, Li B, Marraccino R, Fields S (1994) Two cellular proteins that bind to wild-type but not mutant p53. Proc Natl Acad Sci U S A 91: 6098-6102

Jackson SP (2002) Sensing and repairing DNA double-strand breaks. Carcinogenesis 23: $687-696$

Jackson SP, Bartek J (2009) The DNA-damage response in human biology and disease. Nature 461: 1071-1078

Jang ER, Choi JD, Lee JS (2011) Acetyltransferase p300 regulates NBS1-mediated DNA damage response. FEBS Lett 585: 47-52

Jiang X, Wang X (2004) Cytochrome C-mediated apoptosis. Annu Rev Biochem 73: 87106

Jiricny J (2006) The multifaceted mismatch-repair system. Nat Rev Mol Cell Biol 7: 335-346 
Joza N, Susin SA, Daugas E, Stanford WL, Cho SK, Li CY, Sasaki T, Elia AJ, Cheng HY, Ravagnan L, Ferri KF, Zamzami N, Wakeham A, Hakem R, Yoshida H, Kong YY, Mak TW, Zuniga-Pflucker JC, Kroemer G, Penninger JM (2001) Essential role of the mitochondrial apoptosis-inducing factor in programmed cell death. Nature 410: 549554

Jungmichel S, Stucki M (2010) MDC1: The art of keeping things in focus. Chromosoma 119: 337-349

Kamath RS, Fraser AG, Dong Y, Poulin G, Durbin R, Gotta M, Kanapin A, Le Bot N, Moreno S, Sohrmann M, Welchman DP, Zipperlen P, Ahringer J (2003) Systematic functional analysis of the Caenorhabditis elegans genome using RNAi. Nature 421: 231-237

Kang J, Ferguson D, Song H, Bassing C, Eckersdorff M, Alt FW, Xu Y (2005) Functional interaction of $\mathrm{H} 2 \mathrm{AX}, \mathrm{NBS1}$, and p53 in ATM-dependent DNA damage responses and tumor suppression. Mol Cell Biol 25: 661-670

Kang TH, Kim KT (2006) Negative regulation of ERK activity by VRK3-mediated activation of VHR phosphatase. Nat Cell Biol 8: 863-869

Kang TH, Kim KT (2008) VRK3-mediated inactivation of ERK signaling in adult and embryonic rodent tissues. Biochim Biophys Acta 1: 49-58

Kang TH, Park DY, Choi YH, Kim KJ, Yoon HS, Kim KT (2007) Mitotic histone H3 phosphorylation by vaccinia-related kinase 1 in mammalian cells. Mol Cell Biol 27: 8533-8546

Kang TH, Park DY, Kim W, Kim KT (2008) VRK1 phosphorylates CREB and mediates CCND1 expression. J Cell Sci 121: 3035-3041

Kastan MB, Lim DS (2000) The many substrates and functions of ATM. Nat Rev Mol Cell Biol 1: 179-186

Kawanishi S, Hiraku Y, Pinlaor S, Ma N (2006) Oxidative and nitrative DNA damage in animals and patients with inflammatory diseases in relation to inflammation-related carcinogenesis. Biol Chem 387: 365-372

Kelley MR, Fishel ML (2008) DNA repair proteins as molecular targets for cancer therapeutics. Anticancer Agents Med Chem 8: 417-425

Kerr JF, Wyllie AH, Currie AR (1972) Apoptosis: a basic biological phenomenon with wide-ranging implications in tissue kinetics. Br J Cancer 26: 239-257

Khalil HS TH, Chakarov S, Zhelev N, Lane DP. (2012) Targeting ATM pathway for therapeutic intervention in cancer. Biodiscovery 1: 3; DOI: 10.7750/BioDiscovery.2012.1.3 
Khanna KK, Lavin MF, Jackson SP, Mulhern TD (2001) ATM, a central controller of cellular responses to DNA damage. Cell Death Differ 8: 1052-1065

Kim BJ, Ryu SW, Song BJ (2006) JNK- and p38 kinase-mediated phosphorylation of Bax leads to its activation and mitochondrial translocation and to apoptosis of human hepatoma HepG2 cells. J Biol Chem 281: 21256-21265

Kim H, Tu HC, Ren D, Takeuchi O, Jeffers JR, Zambetti GP, Hsieh JJ, Cheng EH (2009) Stepwise activation of BAX and BAK by $\mathrm{BIID}, \mathrm{BIM}$, and PUMA initiates mitochondrial apoptosis. Mol Cell 36: 487-499

Kim J, Choi YH, Chang S, Kim KT, Je JH (2012a) Defective folliculogenesis in female mice lacking Vaccinia-related kinase 1. Sci Rep 2: 25

Kim W, Chakraborty G, Kim S, Shin J, Park CH, Jeong MW, Bharatham N, Yoon HS, Kim KT (2012b) Macro histone H2A1.2 (macroH2A1) protein suppresses mitotic kinase VRK1 during interphase. J Biol Chem 287: 5278-5289

Kinoshita E, van der Linden E, Sanchez H, Wyman C (2009) RAD50, an SMC family member with multiple roles in DNA break repair: how does ATP affect function? Chromosome Res 17: 277-288

Klerkx EP, Lazo PA, Askjaer P (2009) Emerging biological functions of the vacciniarelated kinase (VRK) family. Histol Histopathol 24: 749-759

Knight ZA, Lin H, Shokat KM (2010) Targeting the cancer kinome through polypharmacology. Nat Rev Cancer 10: 130-137

Kobayashi J, Antoccia A, Tauchi H, Matsuura S, Komatsu K (2004) NBS1 and its functional role in the DNA damage response. DNA Repair (Amst) 3: 855-861

Kobayashi J, Tauchi H, Chen B, Burma S, Tashiro S, Matsuura S, Tanimoto K, Chen DJ, Komatsu K (2009) Histone H2AX participates the DNA damage-induced ATM activation through interaction with NBS1. Biochem Biophys Res Commun 380: 752757

Kobayashi J, Tauchi H, Sakamoto S, Nakamura A, Morishima K, Matsuura S, Kobayashi T, Tamai K, Tanimoto K, Komatsu K (2002) NBS1 localizes to gamma-H2AX foci through interaction with the FHA/BRCT domain. Curr Biol 12: 1846-1851

Kolas NK, Chapman JR, Nakada S, Ylanko J, Chahwan R, Sweeney FD, Panier S, Mendez M, Wildenhain J, Thomson TM, Pelletier L, Jackson SP, Durocher D (2007) Orchestration of the DNA-damage response by the RNF8 ubiquitin ligase. Science 318: $1637-1640$

Kozlov SV, Graham ME, Jakob B, Tobias F, Kijas AW, Tanuji M, Chen P, Robinson PJ, Taucher-Scholz G, Suzuki K, So S, Chen D, Lavin MF (2011) Autophosphorylation and ATM activation: additional sites add to the complexity. J Biol Chem 286: 9107-9119 
Kroonen J, Artesi M, Capraro V, Nguyen-Khac MT, Willems M, Chakravarti A, Bours V, Robe PA (2012) Casein kinase 2 inhibition modulates the DNA damage response but fails to radiosensitize malignant glioma cells. Int J Oncol 41: 776-782

Kruhlak MJ, Celeste A, Dellaire G, Fernandez-Capetillo O, Muller WG, McNally JG, Bazett-Jones DP, Nussenzweig A (2006) Changes in chromatin structure and mobility in living cells at sites of DNA double-strand breaks. J Cell Biol 172: 823-834

Kumar R, Horikoshi N, Singh M, Gupta A, Misra HS, Albuquerque K, Hunt CR, Pandita TK (2012) Chromatin modifications and the DNA damage response to ionizing radiation. Front Oncol 2: 214

Kurz EU, Douglas P, Lees-Miller SP (2004) Doxorubicin activates ATM-dependent phosphorylation of multiple downstream targets in part through the generation of reactive oxygen species. J Biol Chem 279: 53272-53281

Kurz EU, Lees-Miller SP (2004) DNA damage-induced activation of ATM and ATMdependent signaling pathways. DNA Repair 3: 889-900

Kuwana T, Mackey MR, Perkins G, Ellisman MH, Latterich M, Schneiter R, Green DR, Newmeyer DD (2002) Bid, Bax, and lipids cooperate to form supramolecular openings in the outer mitochondrial membrane. Cell 111: 331-342

Lakin ND, Jackson SP (1999) Regulation of p53 in response to DNA damage. Oncogene 18: 7644-7655

Lalier L, Cartron PF, Juin P, Nedelkina S, Manon S, Bechinger B, Vallette FM (2007) Bax activation and mitochondrial insertion during apoptosis. Apoptosis 12: 887-896

Lamarche BJ, Orazio NI, Weitzman MD (2010) The MRN complex in double-strand break repair and telomere maintenance. FEBS Lett 584: 3682-3695

Lancaster OM, Cullen CF, Ohkura H (2007) NHK-1 phosphorylates BAF to allow karyosome formation in the Drosophila oocyte nucleus. J Cell Biol 179: 817-824

Lavin MF (2007) ATM and the Mre11 complex combine to recognize and signal DNA double-strand breaks. Oncogene 26: 7749-7758

Lavin MF (2008) Ataxia-telangiectasia: from a rare disorder to a paradigm for cell signalling and cancer. Nat Rev Mol Cell Biol 9: 759-769

Leadon SA (1996) Repair of DNA Damage Produced by lonizing Radiation: A Minireview. Semin Radiat Oncol 6: 295-305

LeBron C, Chen L, Gilkes DM, Chen J (2006) Regulation of MDMX nuclear import and degradation by Chk2 and 14-3-3. EMBO J 25: 1196-1206 
Lee H, Kwak HJ, Cho IT, Park SH, Lee CH (2009) S1219 residue of 53BP1 is phosphorylated by ATM kinase upon DNA damage and required for proper execution of DNA damage response. Biochem Biophys Res Commun 378: 32-36

Lee JH, Paull TT (2004) Direct activation of the ATM protein kinase by the Mre11/Rad50/Nbs1 complex. Science 304: 93-96

Lee JH, Paull TT (2005) ATM activation by DNA double-strand breaks through the Mre11-Rad50-Nbs1 complex. Science 308: 551-554

Lee JH, Paull TT (2007) Activation and regulation of ATM kinase activity in response to DNA double-strand breaks. Oncogene 26: 7741-7748

Lee SM, Youn B, Kim CS, Kang C, Kim J (2005) Gamma-irradiation and doxorubicin treatment of normal human cells cause cell cycle arrest via different pathways. Mol Cells 20: 331-338

Li J, Stern DF (2005) DNA damage regulates Chk2 association with chromatin. J Biol Chem 280: 37948-37956

Li LY, Liu MY, Shih HM, Tsai CH, Chen JY (2006) Human cellular protein VRK2 interacts specifically with Epstein-Barr virus BHRF1, a homologue of $\mathrm{Bcl}-2$, and enhances cell survival. J Gen Virol 87: 2869-2878

Li LY, Luo X, Wang X (2001) Endonuclease G is an apoptotic DNase when released from mitochondria. Nature 412: 95-99

Li X, Heyer WD (2008) Homologous recombination in DNA repair and DNA damage tolerance. Cell Res 18: 99-113

Lieber MR (2010) The mechanism of double-strand DNA break repair by the nonhomologous DNA end-joining pathway. Annu Rev Biochem 79: 181-211

Lieber MR, Ma Y, Pannicke U, Schwarz K (2003) Mechanism and regulation of human non-homologous DNA end-joining. Nat Rev Mol Cell Biol 4: 712-720

Lim DS, Kim ST, Xu B, Maser RS, Lin J, Petrini JH, Kastan MB (2000) ATM phosphorylates p95/nbs1 in an S-phase checkpoint pathway. Nature 404: 613-617

Linseman DA, Butts BD, Precht TA, Phelps RA, Le SS, Laessig TA, Bouchard RJ, FlorezMcClure ML, Heidenreich KA (2004) Glycogen synthase kinase-3beta phosphorylates Bax and promotes its mitochondrial localization during neuronal apoptosis. J Neurosci 24: 9993-10002

Liu LF, Desai SD, Li TK, Mao Y, Sun M, Sim SP (2000) Mechanism of action of camptothecin. Ann N Y Acad Sci 922: 1-10 
Lok GT, Sy SM, Dong SS, Ching YP, Tsao SW, Thomson TM, Huen MS (2012) Differential regulation of RNF8-mediated Lys48- and Lys63-based polyubiquitylation. Nucleic Acids Res 40: 196-205

Lopes RB, Gangeswaran R, McNeish IA, Wang Y, Lemoine NR (2007) Expression of the IAP protein family is dysregulated in pancreatic cancer cells and is important for resistance to chemotherapy. Int J Cancer 120: 2344-2352

Lopez-Borges S, Lazo PA (2000) The human vaccinia-related kinase 1 (VRK1) phosphorylates threonine-18 within the $\mathrm{mdm}-2$ binding site of the p53 tumour suppressor protein. Oncogene 19: 3656-3664

Lopez-Sanchez I, Sanz-Garcia M, Lazo PA (2009) PIk3 interacts with and specifically phosphorylates VRK1 in Ser342, a downstream target in a pathway that induces Golgi fragmentation. Mol Cell Biol 29: 1189-1201

Lopez-Sanchez I, Valbuena A, Vazquez-Cedeira M, Khadake J, Sanz-Garcia M, Carrillo A, Lazo PA (2014) VRK1 interacts with p53 forming a basal complex that is activated by UV-induced DNA damage. FEBS Lett 31: 00069-00066

Lord CJ, Ashworth A (2012) The DNA damage response and cancer therapy. Nature 481: $287-294$

Lu B, Bishop CE (2003) Late onset of spermatogenesis and gain of fertility in POGdeficient mice indicate that POG is not necessary for the proliferation of spermatogonia. Biol Reprod 69: 161-168

Lu CS, Truong LN, Aslanian A, Shi LZ, Li Y, Hwang PY, Koh KH, Hunter T, Yates JR, 3rd, Berns MW, Wu X (2012) The RING finger protein RNF8 ubiquitinates Nbs1 to promote DNA double-strand break repair by homologous recombination. J Biol Chem 287: 43984-43994

Lukas C, Falck J, Bartkova J, Bartek J, Lukas J (2003) Distinct spatiotemporal dynamics of mammalian checkpoint regulators induced by DNA damage. Nat Cell Biol 5: 255260

Lukas J. (2010) The interface between the ubiquitin family and the DNA damage response. EMBO Rep. , Vol. 11, pp. 907-909.

Lukas J, Lukas C, Bartek J (2011) More than just a focus: The chromatin response to DNA damage and its role in genome integrity maintenance. Nat Cell Biol 13: 11611169

Lloyd J, Chapman JR, Clapperton JA, Haire LF, Hartsuiker E, Li J, Carr AM, Jackson SP, Smerdon SJ (2009) A supramodular FHA/BRCT-repeat architecture mediates Nbs1 adaptor function in response to DNA damage. Cell 139: 100-111 
Mahaney BL, Meek K, Lees-Miller SP (2009) Repair of ionizing radiation-induced DNA double-strand breaks by non-homologous end-joining. Biochem J 417: 639-650

Mailand N, Bekker-Jensen S, Faustrup H, Melander F, Bartek J, Lukas C, Lukas J (2007) RNF8 ubiquitylates histones at DNA double-strand breaks and promotes assembly of repair proteins. Cell 131: $887-900$

Manning G, Plowman GD, Hunter T, Sudarsanam S (2002a) Evolution of protein kinase signaling from yeast to man. Trends Biochem Sci 27: 514-520

Manning G, Whyte DB, Martinez R, Hunter T, Sudarsanam S (2002b) The protein kinase complement of the human genome. Science 298: 1912-1934

Mariotti LG, Pirovano G, Savage KI, Ghita M, Ottolenghi A, Prise KM, Schettino G (2013) Use of the gamma-H2AX Assay to Investigate DNA Repair Dynamics Following Multiple Radiation Exposures. PLoS One 8

Martin NM (2001) DNA repair inhibition and cancer therapy. J Photochem Photobiol B 63: 162-170

Martinou JC, Youle RJ (2011) Mitochondria in apoptosis: Bcl-2 family members and mitochondrial dynamics. Dev Cell 21: 92-101

Matsuoka S, Ballif BA, Smogorzewska A, McDonald ER, 3rd, Hurov KE, Luo J, Bakalarski CE, Zhao Z, Solimini N, Lerenthal Y, Shiloh Y, Gygi SP, Elledge SJ (2007) ATM and ATR substrate analysis reveals extensive protein networks responsive to DNA damage. Science 316: 1160-1166

Matsuoka S, Rotman G, Ogawa A, Shiloh Y, Tamai K, Elledge SJ (2000) Ataxia telangiectasia-mutated phosphorylates Chk2 in vivo and in vitro. Proc Natl Acad Sci U S A 97: 10389-10394

McDonnell TJ, Deane N, Platt FM, Nunez G, Jaeger U, McKearn JP, Korsmeyer SJ (1989) bcl-2-immunoglobulin transgenic mice demonstrate extended $B$ cell survival and follicular lymphoproliferation. Cell 57: 79-88

Meek DW (2004) The p53 response to DNA damage. DNA Repair 3: 1049-1056

Messick TE, Greenberg RA (2009) The ubiquitin landscape at DNA double-strand breaks. J Cell Biol 187: 319-326

Minn AJ, Kettlun CS, Liang H, Kelekar A, Vander Heiden MG, Chang BS, Fesik SW, Fill $\mathrm{M}$, Thompson CB (1999) Bcl-xL regulates apoptosis by heterodimerization-dependent and -independent mechanisms. EMBO J 18: 632-643

Minn AJ, Rudin CM, Boise LH, Thompson CB (1995) Expression of bcl-xL can confer a multidrug resistance phenotype. Blood 86: 1903-1910 
Miquel C, Borrini F, Grandjouan S, Auperin A, Viguier J, Velasco V, Duvillard P, Praz F, Sabourin JC (2005) Role of bax mutations in apoptosis in colorectal cancers with microsatellite instability. Am J Clin Pathol 123: 562-570

Mirzoeva OK, Petrini JH (2003) DNA replication-dependent nuclear dynamics of the Mre11 complex. Mol Cancer Res 1: 207-218

Mitchell KO, Ricci MS, Miyashita T, Dicker DT, Jin Z, Reed JC, El-Deiry WS (2000) Bax is a transcriptional target and mediator of c-myc-induced apoptosis. Cancer Res 60: $6318-6325$

Miyashita T, Reed JC (1995) Tumor suppressor p53 is a direct transcriptional activator of the human bax gene. Cell 80: 293-299

Mochan TA, Venere M, DiTullio RA, Jr., Halazonetis TD (2004) 53BP1, an activator of ATM in response to DNA damage. DNA Repair 3: 945-952

Molitor TP, Traktman P (2014) Depletion of the protein kinase VRK1 disrupts nuclear envelope morphology and leads to BAF retention on mitotic chromosomes. Mol Biol Cell 15: 15

Moll UM, Petrenko O (2003) The MDM2-p53 interaction. Mol Cancer Res 1: 10011008

Monsalve DM, Merced T, Fernandez IF, Blanco S, Vazquez-Cedeira M, Lazo PA (2013) Human VRK2 modulates apoptosis by interaction with $\mathrm{Bcl}-\mathrm{xL}$ and regulation of $\mathrm{BAX}$ gene expression. Cell Death Dis 28: 40

Moon SH, Lin L, Zhang X, Nguyen TA, Darlington Y, Waldman AS, Lu X, Donehower LA (2010) Wild-type p53-induced phosphatase 1 dephosphorylates histone variant gamma-H2AX and suppresses DNA double strand break repair. J Biol Chem 285: 12935-12947

Morris EJ, Geller HM (1996) Induction of neuronal apoptosis by camptothecin, an inhibitor of DNA topoisomerase-I: evidence for cell cycle-independent toxicity. J Cell Biol 134: 757-770

Muchmore SW, Sattler M, Liang H, Meadows RP, Harlan JE, Yoon HS, Nettesheim D, Chang BS, Thompson CB, Wong SL, Ng SL, Fesik SW (1996) X-ray and NMR structure of human Bcl-xL, an inhibitor of programmed cell death. Nature 381: 335-341

Munoz IM, Jowsey PA, Toth R, Rouse J (2007) Phospho-epitope binding by the BRCT domains of hPTIP controls multiple aspects of the cellular response to DNA damage. Nucleic Acids Res 35: 5312-5322

Nakada S, Chen GI, Gingras AC, Durocher D (2008) PP4 is a gamma H2AX phosphatase required for recovery from the DNA damage checkpoint. EMBO Rep 9: 1019-1026 
Nakamura AJ, Rao VA, Pommier Y, Bonner WM (2010) The complexity of phosphorylated $\mathrm{H} 2 \mathrm{AX}$ foci formation and DNA repair assembly at DNA double-strand breaks. Cell Cycle 9: 389-397

Neale MJ, Pan J, Keeney S (2005) Endonucleolytic processing of covalent proteinlinked DNA double-strand breaks. Nature 436: 1053-1057

Network TCGAR (2011) Integrated genomic analyses of ovarian carcinoma. Nature 474: 609-615

Nezu J, Oku A, Jones MH, Shimane M (1997) Identification of two novel human putative serine/threonine kinases, VRK1 and VRK2, with structural similarity to vaccinia virus B1R kinase. Genomics 45: 327-331

Nicassio F, Corrado N, Vissers JH, Areces LB, Bergink S, Marteijn JA, Geverts B, Houtsmuller AB, Vermeulen W, Di Fiore PP, Citterio E (2007) Human USP3 is a chromatin modifier required for $\mathrm{S}$ phase progression and genome stability. Curr Biol 17: $1972-1977$

Nichols RJ, Traktman P (2004) Characterization of three paralogous members of the Mammalian vaccinia related kinase family. J Biol Chem 279: 7934-7946

Nichols RJ, Wiebe MS, Traktman P (2006) The vaccinia-related kinases phosphorylate the $\mathrm{N}^{\prime}$ terminus of $\mathrm{BAF}$, regulating its interaction with DNA and its retention in the nucleus. Mol Biol Cell 17: 2451-2464

Niemi NM, MacKeigan JP (2013) Mitochondrial phosphorylation in apoptosis: flipping the death switch. Antioxid Redox Signal 19: 572-582

Nishijo K, Chen QR, Zhang L, McCleish AT, Rodriguez A, Cho MJ, Prajapati SI, Gelfond JA, Chisholm GB, Michalek JE, Aronow BJ, Barr FG, Randall RL, Ladanyi M, Qualman SJ, Rubin BP, LeGallo RD, Wang C, Khan J, Keller C (2009) Credentialing a preclinical mouse model of alveolar rhabdomyosarcoma. Cancer Res 69: 2902-2911

Nitiss JL (2009) Targeting DNA topoisomerase II in cancer chemotherapy. Nat Rev Cancer 9: 338-350

Nouspikel T (2009) DNA repair in mammalian cells : Nucleotide excision repair: variations on versatility. Cell Mol Life Sci 66: 994-1009

Oberle C, Blattner C (2010) Regulation of the DNA Damage Response to DSBs by Post-Translational Modifications. Curr Genomics 11: 184-198

Oliver FJ, Menissier-de Murcia J, de Murcia G (1999) Poly(ADP-ribose) polymerase in the cellular response to DNA damage, apoptosis, and disease. Am J Hum Genet 64: $1282-1288$ 
Panier S, Durocher D (2009) Regulatory ubiquitylation in response to DNA doublestrand breaks. DNA Repair 8: 436-443

Panier S, Durocher D (2013) Push back to respond better: regulatory inhibition of the DNA double-strand break response. Nat Rev Mol Cell Biol

Park CH, Choi BH, Jeong MW, Kim S, Kim W, Song YS, Kim KT (2011) Protein kinase Cdelta regulates vaccinia-related kinase 1 in DNA damage-induced apoptosis. Mol Biol Cell 22: 1398-1408

Pawlowski J, Kraft AS (2000) Bax-induced apoptotic cell death. Proc Natl Acad Sci U S A 97: 529-531

Pellegrini L, Yu DS, Lo T, Anand S, Lee M, Blundell TL, Venkitaraman AR (2002) Insights into DNA recombination from the structure of a RAD51-BRCA2 complex. Nature 420: 287-293

Pickart CM, Eddins MJ (2004) Ubiquitin: structures, functions, mechanisms. Biochim Biophys Acta 29: 1-3

Polo SE, Jackson SP (2011) Dynamics of DNA damage response proteins at DNA breaks: a focus on protein modifications. Genes Dev 25: 409-433

Powers JT, Hong S, Mayhew CN, Rogers PM, Knudsen ES, Johnson DG (2004) E2F1 uses the ATM signaling pathway to induce p53 and Chk2 phosphorylation and apoptosis. Mol Cancer Res 2: 203-214

Prigent C, Dimitrov S (2003) Phosphorylation of serine 10 in histone H3, what for? J Cell Sci 116: 3677-3685

Ramadan K, Meerang M (2011) Degradation-linked ubiquitin signal and proteasome are integral components of DNA double strand break repair: New perspectives for anti-cancer therapy. FEBS Lett 585: 2868-2875

Ravagnan L, Roumier T, Kroemer G (2002) Mitochondria, the killer organelles and their weapons. J Cell Physiol 192: 131-137

Renbaum P, Kellerman E, Jaron R, Geiger D, Segel R, Lee M, King MC, Levy-Lahad E (2009) Spinal muscular atrophy with pontocerebellar hypoplasia is caused by a mutation in the VRK1 gene. Am J Hum Genet 85: 281-289

Riedl SJ, Salvesen GS (2007) The apoptosome: signalling platform of cell death. Nat Rev Mol Cell Biol 8: 405-413

Riha K, Heacock ML, Shippen DE (2006) The role of the nonhomologous end-joining DNA double-strand break repair pathway in telomere biology. Annu Rev Genet 40: 237-277 
Roux PP, Blenis J (2004) ERK and p38 MAPK-activated protein kinases: a family of protein kinases with diverse biological functions. Microbiol Mol Biol Rev 68: 320-344

Rouzier R, Perou CM, Symmans WF, Ibrahim N, Cristofanilli M, Anderson K, Hess KR, Stec J, Ayers M, Wagner P, Morandi P, Fan C, Rabiul I, Ross JS, Hortobagyi GN, Pusztai L (2005) Breast cancer molecular subtypes respond differently to preoperative chemotherapy. Clin Cancer Res 11: 5678-5685

Ruan Q, Wang Q, Xie S, Fang Y, Darzynkiewicz Z, Guan K, Jhanwar-Uniyal M, Dai W (2004) Polo-like kinase 3 is Golgi localized and involved in regulating Golgi fragmentation during the cell cycle. Exp Cell Res 294: 51-59

Rupinder SK, Gurpreet AK, Manjeet S (2007) Cell suicide and caspases. Vascul Pharmacol 46: 383-393

Rupnik A, Lowndes NF, Grenon M (2010) MRN and the race to the break. Chromosoma 119: 115-135

Saito S, Goodarzi AA, Higashimoto Y, Noda Y, Lees-Miller SP, Appella E, Anderson CW (2002) ATM mediates phosphorylation at multiple p53 sites, including Ser(46), in response to ionizing radiation. J Biol Chem 277: 12491-12494

Salzano M, Vázquez-Cedeira M, Sanz-García M, Valbuena A, Blanco S, Fernandez I, Lazo PA (2014) Vaccinia-related kinase 1 (VRK1) confers resistance to DNAdamaging agents in human breast cancer by affecting DNA

damage response. Oncotarget

Sanchez-Perez I (2006) DNA repair inhibitors in cancer treatment. Clin Transl Oncol 8: 642-646

Santos CR, Rodriguez-Pinilla M, Vega FM, Rodriguez-Peralto JL, Blanco S, Sevilla A, Valbuena A, Hernandez T, van Wijnen AJ, Li F, de Alava E, Sanchez-Cespedes M, Lazo PA (2006) VRK1 signaling pathway in the context of the proliferation phenotype in head and neck squamous cell carcinoma. Mol Cancer Res 4: 177-185

Sanz-Garcia M, Lopez-Sanchez I, Lazo PA (2008) Proteomics identification of nuclear Ran GTPase as an inhibitor of human VRK1 and VRK2 (vaccinia-related kinase) activities. Mol Cell Proteomics 7: 2199-2214

Sanz-Garcia M, Monsalve DM, Sevilla A, Lazo PA (2012) Vaccinia-related kinase 1 (VRK1) is an upstream nucleosomal kinase required for the assembly of 53BP1 foci in response to ionizing radiation-induced DNA damage. J Biol Chem 287: 23757-23768

Sanz-Garcia M, Vazquez-Cedeira M, Kellerman E, Renbaum P, Levy-Lahad E, Lazo PA (2011) Substrate profiling of human vaccinia-related kinases identifies coilin, a Cajal body nuclear protein, as a phosphorylation target with neurological implications. $J$ Proteomics 75: 548-560 
Scott FL, Stec B, Pop C, Dobaczewska MK, Lee JJ, Monosov E, Robinson H, Salvesen GS, Schwarzenbacher R, Riedl SJ (2009) The Fas-FADD death domain complex structure unravels signalling by receptor clustering. Nature 457: 1019-1022

Scheeff ED, Eswaran J, Bunkoczi G, Knapp S, Manning G (2009) Structure of the pseudokinase VRK3 reveals a degraded catalytic site, a highly conserved kinase fold, and a putative regulatory binding site. Structure 17: 128-138

Schiller CB, Lammens K, Guerini I, Coordes B, Feldmann H, Schlauderer F, Mockel C, Schele A, Strasser K, Jackson SP, Hopfner KP (2012) Structure of Mre11-Nbs1 complex yields insights into ataxia-telangiectasia-like disease mutations and DNA damage signaling. Nat Struct Mol Biol 19: 693-700

Schimmer AD (2004) Inhibitor of apoptosis proteins: translating basic knowledge into clinical practice. Cancer Res 64: 7183-7190

Schmitz I, Kirchhoff S, Krammer PH (2000) Regulation of death receptor-mediated apoptosis pathways. Int J Biochem Cell Biol 32: 1123-1136

Schober CS, Aydiner F, Booth CJ, Seli E, Reinke V (2011) The kinase VRK1 is required for normal meiotic progression in mammalian oogenesis. Mech Dev 128: 178-190

Sevilla A, Santos CR, Barcia R, Vega FM, Lazo PA (2004a) c-Jun phosphorylation by the human vaccinia-related kinase 1 (VRK1) and its cooperation with the $\mathrm{N}$-terminal kinase of c-Jun (JNK). Oncogene 23: 8950-8958

Sevilla A, Santos CR, Vega FM, Lazo PA (2004b) Human vaccinia-related kinase 1 (VRK1) activates the ATF2 transcriptional activity by novel phosphorylation on Thr-73 and Ser-62 and cooperates with JNK. J Biol Chem 279: 27458-27465

Shamas-Din A, Brahmbhatt H, Leber B, Andrews DW (2011) BH3-only proteins: Orchestrators of apoptosis. Biochim Biophys Acta 4: 508-520

Shchemelinin I, Sefc L, Necas E (2006) Protein kinases, their function and implication in cancer and other diseases. Folia Biol 52: 81-100

Shiloh Y, Ziv Y (2013) The ATM protein kinase: regulating the cellular response to genotoxic stress, and more. Nat Rev Mol Cell Biol 14: 197-210

Shirley RB, Kaddour-Djebbar I, Patel DM, Lakshmikanthan V, Lewis RW, Kumar MV (2005) Combination of proteasomal inhibitors lactacystin and MG132 induced synergistic apoptosis in prostate cancer cells. Neoplasia 7: 1104-1111

Shrivastav M, De Haro LP, Nickoloff JA (2008) Regulation of DNA double-strand break repair pathway choice. Cell Res 18: 134-147

Siegel RM (2006) Caspases at the crossroads of immune-cell life and death. Nat Rev Immunol 6: 308-317 
Smith J, Tho LM, Xu N, Gillespie DA (2010) The ATM-Chk2 and ATR-Chk1 pathways in DNA damage signaling and cancer. Adv Cancer Res 108: 73-112

Soldani C, Scovassi Al (2002) Poly(ADP-ribose) polymerase-1 cleavage during apoptosis: an update. Apoptosis 7: 321-328

Steinberg $S$, de Jong $S$, Andreassen OA, Werge $T$, Borglum AD, Mors O, Mortensen PB, Gustafsson O, Costas J, Pietilainen OP, Demontis D, Papiol S, Huttenlocher J, Mattheisen M, Breuer R, Vassos E, Giegling I, Fraser G, Walker N, Tuulio-Henriksson A, Suvisaari J, Lonnqvist J, Paunio T, Agartz I, Melle I, Djurovic S, Strengman E, Jurgens $G$, Glenthoj B, Terenius $L$, Hougaard DM, Orntoft T, Wiuf $C$, Didriksen $M$, Hollegaard MV, Nordentoft M, van Winkel R, Kenis G, Abramova L, Kaleda V, Arrojo M, Sanjuan J, Arango C, Sperling S, Rossner M, Ribolsi M, Magni V, Siracusano A, Christiansen C, Kiemeney LA, Veldink J, van den Berg L, Ingason A, Muglia P, Murray $R$, Nothen MM, Sigurdsson E, Petursson $H$, Thorsteinsdottir $U$, Kong A, Rubino IA, De Hert M, Rethelyi JM, Bitter I, Jonsson EG, Golimbet V, Carracedo A, Ehrenreich $H$, Craddock N, Owen MJ, O'Donovan MC, Ruggeri M, Tosato S, Peltonen L, Ophoff RA, Collier DA, St Clair D, Rietschel M, Cichon S, Stefansson H, Rujescu D, Stefansson K (2011) Common variants at VRK2 and TCF4 conferring risk of schizophrenia. Hum Mol Genet 20: 4076-4081

Stetler RA, Gao Y, Zhang L, Weng Z, Zhang F, Hu X, Wang S, Vosler P, Cao G, Sun D, Graham SH, Chen J (2012) Phosphorylation of HSP27 by protein kinase D is essential for mediating neuroprotection against ischemic neuronal injury. J Neurosci 32: 26672682

Stevens C, Smith L, La Thangue NB (2003) Chk2 activates E2F-1 in response to DNA damage. Nat Cell Biol 5: 401-409

Stewart GS, Wang B, Bignell CR, Taylor AM, Elledge SJ (2003) MDC1 is a mediator of the mammalian DNA damage checkpoint. Nature 421: 961-966

Stiff T, O'Driscoll M, Rief N, Iwabuchi K, Lobrich M, Jeggo PA (2004) ATM and DNA-PK function redundantly to phosphorylate $\mathrm{H} 2 \mathrm{AX}$ after exposure to ionizing radiation. Cancer Res 64: 2390-2396

Stokes MP, Rush J, Macneill J, Ren JM, Sprott K, Nardone J, Yang V, Beausoleil SA, Gygi SP, Livingstone M, Zhang H, Polakiewicz RD, Comb MJ (2007) Profiling of UVinduced ATM/ATR signaling pathways. Proc Natl Acad Sci U S A 104: 19855-19860

Stolz A, Ertych N, Bastians H (2011) Tumor suppressor CHK2: regulator of DNA damage response and mediator of chromosomal stability. Clin Cancer Res 17: 401405

Stracker TH, Petrini JH (2011) The MRE11 complex: starting from the ends. Nat Rev Mol Cell Biol 12: 90-103 
Stucki M, Jackson SP (2004) MDC1/NFBD1: a key regulator of the DNA damage response in higher eukaryotes. DNA Repair 3: 953-957

Sun Y, Xu Y, Roy K, Price BD (2007) DNA damage-induced acetylation of lysine 3016 of ATM activates ATM kinase activity. Mol Cell Biol 27: 8502-8509

Tait SW, Green DR (2010) Mitochondria and cell death: outer membrane permeabilization and beyond. Nat Rev Mol Cell Biol 11: 621-632

Tauchi H, Matsuura S, Kobayashi J, Sakamoto S, Komatsu K (2002) Nijmegen breakage syndrome gene, NBS1, and molecular links to factors for genome stability. Oncogene 21: 8967-8980

Taylor AM, Groom A, Byrd PJ (2004) Ataxia-telangiectasia-like disorder (ATLD)-its clinical presentation and molecular basis. DNA Repair (Amst) 3: 1219-1225

Taylor RC, Cullen SP, Martin SJ (2008) Apoptosis: controlled demolition at the cellular level. Nat Rev Mol Cell Biol 9: 231-241

Taylor SS, Kornev AP (2011) Protein kinases: evolution of dynamic regulatory proteins. Trends Biochem Sci 36: 65-77

Tewey KM, Rowe TC, Yang L, Halligan BD, Liu LF (1984) Adriamycin-induced DNA damage mediated by mammalian DNA topoisomerase II. Science 226: 466-468

Thompson LH (2012) Recognition, signaling, and repair of DNA double-strand breaks produced by ionizing radiation in mammalian cells: the molecular choreography. Mutat Res 751: 158-246

Tobias F, Lob D, Lengert N, Durante M, Drossel B, Taucher-Scholz G, Jakob B (2013) Spatiotemporal dynamics of early DNA damage response proteins on complex DNA lesions. PLoS One 8: e57953

Towbin H, Staehelin T, Gordon J (1979) Electrophoretic transfer of proteins from polyacrylamide gels to nitrocellulose sheets: procedure and some applications. Proc Natl Acad Sci U S A 76: 4350-4354

Traganos F, Seiter K, Feldman E, Halicka HD, Darzynkiewicz Z (1996) Induction of apoptosis by camptothecin and topotecan. Ann N Y Acad Sci 803: 101-110

Ubersax JA, Ferrell JE, Jr. (2007) Mechanisms of specificity in protein phosphorylation. Nat Rev Mol Cell Biol 8: 530-541

Ulukaya E, Acilan C, Yilmaz Y (2011) Apoptosis: why and how does it occur in biology? Cell Biochem Funct 29: 468-480

Unsal-Kacmaz K, Makhov AM, Griffith JD, Sancar A (2002) Preferential binding of ATR protein to UV-damaged DNA. Proc Natl Acad Sci U S A 99: 6673-6678 
Uziel T, Lerenthal Y, Moyal L, Andegeko Y, Mittelman L, Shiloh Y (2003) Requirement of the MRN complex for ATM activation by DNA damage. EMBO J 22: 5612-5621

Valbuena A, Blanco S, Vega FM, Lazo PA (2008a) The C/H3 domain of p300 is required to protect VRK1 and VRK2 from their downregulation induced by p53. PLoS One 3: 0002649

Valbuena A, Castro-Obregon S, Lazo PA (2011a) Downregulation of VRK1 by p53 in response to DNA damage is mediated by the autophagic pathway. PLoS One 6: 0017320

Valbuena A, Lopez-Sanchez I, Lazo PA (2008b) Human VRK1 is an early response gene and its loss causes a block in cell cycle progression. PLoS One 3: 0001642

Valbuena A, Lopez-Sanchez I, Vega FM, Sevilla A, Sanz-Garcia M, Blanco S, Lazo PA (2007a) Identification of a dominant epitope in human vaccinia-related kinase 1 (VRK1) and detection of different intracellular subpopulations. Arch Biochem Biophys 465: $219-226$

Valbuena A, Sanz-Garcia M, Lopez-Sanchez I, Vega FM, Lazo PA (2011b) Roles of VRK1 as a new player in the control of biological processes required for cell division. Cell Signal 23: 1267-1272

Valbuena A, Suarez-Gauthier A, Lopez-Rios F, Lopez-Encuentra A, Blanco S, Fernandez PL, Sanchez-Cespedes M, Lazo PA (2007b) Alteration of the VRK1-p53 autoregulatory loop in human lung carcinomas. Lung Cancer 58: 303-309

Valbuena A, Vega FM, Blanco S, Lazo PA (2006) p53 downregulates its activating vaccinia-related kinase 1, forming a new autoregulatory loop. Mol Cell Biol 26: 47824793

Valerie K, Yacoub A, Hagan MP, Curiel DT, Fisher PB, Grant S, Dent P (2007) Radiation-induced cell signaling: inside-out and outside-in. Mol Cancer Ther 6: 789801

van Dam H, Castellazzi M (2001) Distinct roles of Jun : Fos and Jun : ATF dimers in oncogenesis. Oncogene 20: 2453-2464

van den Bosch M, Bree RT, Lowndes NF (2003) The MRN complex: coordinating and mediating the response to broken chromosomes. EMBO Rep 4: 844-849

van der Linden E, Sanchez H, Kinoshita E, Kanaar R, Wyman C (2009) RAD50 and NBS1 form a stable complex functional in DNA binding and tethering. Nucleic Acids Res 37: 1580-1588

van Gent DC, van der Burg M (2007) Non-homologous end-joining, a sticky affair. Oncogene 26: 7731-7740 
Vazquez-Cedeira M, Barcia-Sanjurjo I, Sanz-Garcia M, Barcia R, Lazo PA (2011) Differential inhibitor sensitivity between human kinases VRK1 and VRK2. PLoS One 6: 4

Vazquez-Cedeira M, Lazo PA (2012) Human VRK2 (vaccinia-related kinase 2) modulates tumor cell invasion by hyperactivation of NFAT1 and expression of cyclooxygenase-2. J Biol Chem 287: 42739-42750

Vega FM, Gonzalo P, Gaspar ML, Lazo PA (2003) Expression of the VRK (vacciniarelated kinase) gene family of p53 regulators in murine hematopoietic development. FEBS Lett 544: 176-180

Vega FM, Sevilla A, Lazo PA (2004) p53 Stabilization and accumulation induced by human vaccinia-related kinase 1. Mol Cell Biol 24: 10366-10380

Velimezi G, Liontos M, Vougas K, Roumeliotis T, Bartkova J, Sideridou M, Dereli-Oz A, Kocylowski M, Pateras IS, Evangelou K, Kotsinas A, Orsolic I, Bursac S, CokaricBrdovcak M, Zoumpourlis V, Kletsas D, Papafotiou G, Klinakis A, Volarevic S, Gu W, Bartek J, Halazonetis TD, Gorgoulis VG (2013) Functional interplay between the DNAdamage-response kinase ATM and ARF tumour suppressor protein in human cancer. Nat Cell Biol 15: 967-977

Wajant $\mathrm{H}$ (2002) The Fas signaling pathway: more than a paradigm. Science 296: 1635-1636

Walsh T, King MC Ten genes for inherited breast cancer: Cancer Cell. 2007 Feb;11(2):103-5.

Waltes R, Kalb R, Gatei M, Kijas AW, Stumm M, Sobeck A, Wieland B, Varon R, Lerenthal $Y$, Lavin MF, Schindler D, Dork T (2009) Human RAD50 deficiency in a Nijmegen breakage syndrome-like disorder. Am J Hum Genet 84: 605-616

Ward IM, Minn K, Jorda KG, Chen J (2003) Accumulation of checkpoint protein 53BP1 at DNA breaks involves its binding to phosphorylated histone H2AX. J Biol Chem 278: 19579-19582

Waters K, Yang AZ, Reinke V (2010) Genome-wide analysis of germ cell proliferation in C.elegans identifies VRK-1 as a key regulator of CEP-1/p53. Dev Biol 344: 10111025

Watrin E, Peters JM (2009) The cohesin complex is required for the DNA damageinduced G2/M checkpoint in mammalian cells. EMBO J 28: 2625-2635

Weber CH, Vincenz C (2001) The death domain superfamily: a tale of two interfaces? Trends Biochem Sci 26: 475-481 
Wen J, Cerosaletti K, Schultz KJ, Wright JA, Concannon P (2013) NBN Phosphorylation regulates the accumulation of MRN and ATM at sites of DNA double-strand breaks. Oncogene 32: 4448-4456

West SC (2003) Molecular views of recombination proteins and their control. Nat Rev Mol Cell Biol 4: 435-445

Whitmarsh AJ, Kuan CY, Kennedy NJ, Kelkar N, Haydar TF, Mordes JP, Appel M, Rossini AA, Jones SN, Flavell RA, Rakic P, Davis RJ (2001) Requirement of the JIP1 scaffold protein for stress-induced JNK activation. Genes Dev 15: 2421-2432

Wiebe MS, Nichols RJ, Molitor TP, Lindgren JK, Traktman P (2010) Mice deficient in the serine/threonine protein kinase VRK1 are infertile due to a progressive loss of spermatogonia. Biol Reprod 82: 182-193

Williams GJ, Lees-Miller SP, Tainer JA (2010) Mre11-Rad50-Nbs1 conformations and the control of sensing, signaling, and effector responses at DNA double-strand breaks. DNA Repair 9: 1299-1306

Williams RS, Moncalian G, Williams JS, Yamada Y, Limbo O, Shin DS, Groocock LM, Cahill D, Hitomi C, Guenther G, Moiani D, Carney JP, Russell P, Tainer JA (2008) Mre11 dimers coordinate DNA end bridging and nuclease processing in doublestrand-break repair. Cell 135: 97-109

Willis SN, Chen L, Dewson G, Wei A, Naik E, Fletcher JI, Adams JM, Huang DC (2005) Proapoptotic Bak is sequestered by $\mathrm{Mcl}-1$ and $\mathrm{Bcl}-\mathrm{xL}$, but not $\mathrm{Bcl}-2$, until displaced by BH3-only proteins. Genes Dev 19: 1294-1305

Wong RS (2011) Apoptosis in cancer: from pathogenesis to treatment. J Exp Clin Cancer Res 30: 1756-9966

Wu J, Lu LY, Yu X (2010) The role of BRCA1 in DNA damage response. Protein Cell 1: 117-123

Wu X, Ranganathan V, Weisman DS, Heine WF, Ciccone DN, O'Neill TB, Crick KE, Pierce KA, Lane WS, Rathbun G, Livingston DM, Weaver DT (2000) ATM phosphorylation of Nijmegen breakage syndrome protein is required in a DNA damage response. Nature 405: 477-482

Xia F, Taghian DG, DeFrank JS, Zeng ZC, Willers H, lliakis G, Powell SN (2001) Deficiency of human BRCA2 leads to impaired homologous recombination but maintains normal nonhomologous end joining. Proc Natl Acad Sci U S A 98: 86448649

Xiao A, Li H, Shechter D, Ahn SH, Fabrizio LA, Erdjument-Bromage $H$, IshibeMurakami S, Wang B, Tempst P, Hofmann K, Patel DJ, Elledge SJ, Allis CD (2009) WSTF regulates the H2A.X DNA damage response via a novel tyrosine kinase activity. Nature 457: 57-62 
Xie A, Kwok A, Scully R (2009) Role of mammalian Mre11 in classical and alternative nonhomologous end joining. Nat Struct Mol Biol 16: 814-818

Xie S, Wang Q, Ruan Q, Liu T, Jhanwar-Uniyal M, Guan K, Dai W (2004) MEK1induced Golgi dynamics during cell cycle progression is partly mediated by Polo-like kinase-3. Oncogene 23: 3822-3829

Xie Y (2010) Structure, assembly and homeostatic regulation of the 265 proteasome. J Mol Cell Biol 2: 308-317

Yamauchi M, Oka Y, Yamamoto M, Niimura K, Uchida M, Kodama S, Watanabe M, Sekine I, Yamashita S, Suzuki K (2008) Growth of persistent foci of DNA damage checkpoint factors is essential for amplification of G1 checkpoint signaling. DNA Repair 7: 405-417

Yarden RI, Pardo-Reoyo S, Sgagias M, Cowan KH, Brody LC (2002) BRCA1 regulates the G2/M checkpoint by activating Chk1 kinase upon DNA damage. Nat Genet 30: 285-289

You Z, Chahwan C, Bailis J, Hunter T, Russell P (2005) ATM activation and its recruitment to damaged DNA require binding to the $C$ terminus of Nbs1. Mol Cell Biol 25: 5363-5379

Youle RJ, Strasser A (2008) The BCL-2 protein family: opposing activities that mediate cell death. Nat Rev Mol Cell Biol 9: 47-59

Yuan J, Chen J (2010) MRE11-RAD50-NBS1 complex dictates DNA repair independent of H2AX. J Biol Chem 285: 1097-1104

Yuan SS, Lee SY, Chen G, Song M, Tomlinson GE, Lee EY (1999) BRCA2 is required for ionizing radiation-induced assembly of Rad51 complex in vivo. Cancer Res 59: 35473551

Yuichiru Saito HF, Junya Kobayashi (2013) Role of NBS1 in DNA damage response and its relationship with cancer development. Trans/ Cancer Res 2: 178-189

Zelko I, Kobayashi R, Honkakoski P, Negishi M (1998) Molecular cloning and characterization of a novel nuclear protein kinase in mice. Arch Biochem Biophys 352: $31-36$

Zhang J, Yang PL, Gray NS (2009) Targeting cancer with small molecule kinase inhibitors. Nat Rev Cancer 9: 28-39

Zhang Y, Zhou J, Lim CU (2006) The role of NBS1 in DNA double strand break repair, telomere stability, and cell cycle checkpoint control. Cell Res 16: 45-54 
Zhang ZW, Patchett SE, Farthing MJ (2000) Topoisomerase I inhibitor (camptothecin)-induced apoptosis in human gastric cancer cells and the role of wildtype $\mathrm{p} 53$ in the enhancement of its cytotoxicity. Anticancer Drugs 11: 757-764

Zhao S, Weng YC, Yuan SS, Lin YT, Hsu HC, Lin SC, Gerbino E, Song MH, Zdzienicka MZ, Gatti RA, Shay JW, Ziv Y, Shiloh Y, Lee EY (2000) Functional link between ataxiatelangiectasia and Nijmegen breakage syndrome gene products. Nature 405: 473477

Zhuang X, Semenova E, Maric D, Craigie R (2013) Dephosphorylation of barrier-toautointegration-factor by protein phosphatase 4 and its role in cell mitosis. $J$ Biol Chem 21: 21 

Parte del trabajo mostrado en esta tesis doctoral ha sido publicado en los siguientes artículos científicos:

Sanz-Garcia M, Monsalve DM, Sevilla A, Lazo PA (2012) Vaccinia-related kinase 1 (VRK1) is an upstream nucleosomal kinase required for the assembly of 53BP1 foci in response to ionizing radiation-induced DNA damage. J Biol Chem 287: 23757-23768

Monsalve DM, Merced T, Fernandez IF, Blanco S, Vazquez-Cedeira M, Lazo PA (2013) Human VRK2 modulates apoptosis by interaction with $\mathrm{Bcl}-\mathrm{xL}$ and regulation of $\mathrm{BAX}$ gene expression. Cell Death Dis 28: 40 



\section{AGRADECIMIENTOS}

Ya culminando la escritura de esta tesis, había llegado el momento de escribir unas cuantas líneas de agradecimiento, comienzo con el título, es lo más fácil y me ayuda a centrarme en lo que quiero plasmar, en lo que quiero transmitir, pero mi mente se queda en blanco momentáneamente, ¿unas cuantas líneas Diana? creo que no bastarán para agradecer a todas las personas que han pasado por mi vida, a todas aquellas que han caminado junto a mí por esta parte del camino. No pensé que escribir "estas cuantas líneas" me hiciera sentir tan emocionada ivaya carga de sentimientos!

En primer lugar quiero agradecer a Pedro A. Lazo, mi tutor de tesis, sin él esta gran aventura nunca hubiera iniciado. Gracias por aceptarme en el grupo, gracias por haberme dado la oportunidad de superarme profesionalmente, por abrirme las puertas hacia el mundo de la ciencia, que a pesar de sus altibajos siempre me ha apasionado.

Gracias a todas las personas del laboratorio 4, a los que están y a los que ya se han ido. A Marta, por sus enseñanzas y paciencia y más aún cuando llegue a España y no entendía lo que decía por mi acento. A Inma y a Isiña, gracias por acogerme de tan buena manera y por calmar esa angustia que se siente al llegar a un país desconocido, gracias por ese apoyo y las palabras de ánimo que siempre me han dado, y a pesar de que estemos lejos, siempre las he sentido muy presentes en mi vida. A Alberto, Marcella y Martiña por ser parte de mi crecimiento profesional. Martiña nunca olvidaré cuando cocinaste ese delicioso pulpo a la gallega por mi cumpleaños, gracias por tantos detalles y por estar siempre dispuesta a ayudarme. A mi linda Virgi, gracias por esos abrazos apapachaditos que siempre me diste cuando más los necesitaba, por ser ejemplo de esfuerzo y dedicación y por todos los regaños y ánimos que me diste hasta el último momento. Y como olvidar a mi pollito Fer, que chico más majo eres, gracias por estar pendiente de mí, fue poco tiempo pero el suficiente para hacer una linda amistad. A los "niños" nuevos, Nacho, Elena y Ana Clara, fue un verdadero placer haberlos conocido y compartir tantos momentos con ustedes, buen viento y buena mar para este comienzo en la ciencia; y en especial a ti, Ana Clara, gracias por llegar a mi vida en un momento delicado donde con tus palabras me ayudaste a comprender que aunque duela el alma siempre hay que seguir adelante. iA mi portugués más querido de todos! ¡Mi David! Gracias por ese apoyo incondicional, por esa sensibilidad y buen corazón que nos hace sentir seguras a tu lado, por dejarte morder el brazo, por esos abrazos tan reconfortantes, por esa espontaneidad de tus palabras que nos hace reír tanto, no por nada te decimos que 
casi nunca hablas, pero cuando hablas... Gracias por compartir conmigo tus momentos más importantes, nunca olvidaré esa notica que escribiste en mi tesis, cuida muy bien de Ana Teresa y de mi bolinho, y iánimo! que ya queda poco, iAh! y no, no me he olvidado de ti, mi querida Lara, Lara, Lara...

Albóndiga, no sé ni por dónde comenzar, no creo que existan suficientes palabras para agradecerte todo lo que has hecho por mí. Me alegra tanto que hayas llegado a mi vida... Pero me impresiona aún más la manera en que te has acomodado y te has hecho un hueco a pulso en mi corazón (y bien merecido que lo tienes). Gracias por tus consejos, por los debates de cualquier tema personal o profesional (¿nunca nos cansamos de hablar eh?), por consentirme, por comprenderme, por los viajes (¿cuál es nuestro próximo destino?), por las cenas de chicas, por enseñarme a cocinar, por hacerme arepas con chocolate (¿no se supone que debería ser al revés?), por enseñarme que comer pescado no es tan terrible, por comerte los pedacitos de pan que no quería, por sacrificar tu tiempo libre para ayudarme con la tesis, por soportarme, por salir de compras, por los tequilas, por los tantos buenos momentos que hemos vivido juntas y también por los malos, por llorar conmigo, por acompañarme en las noches cuando más mal me sentía, por convertirte en mis muletas, en mi fuerza, en mi apoyo... en mi ángel de la guarda, sobre todo en este último año que mi vida ha cambiado tanto. Siento mucho haberte puesto tanto peso encima, pero este logro no es solo mío, también es tuyo. Sabes que pienso en ti como si fueras mi hermana españolita (ya sé que naciste en el lugar equivocado), y sabes que aunque tengamos de por medio miles de kilómetros de distancia, siempre serás parte de mí y de mi familia. ¡¡No olvides nuestra promesa!!

A la familia Cantarero Abad, gracias por esa calidez hogareña que siempre me hicieron sentir, porque siempre me recibieron con los brazos abiertos y con una sonrisa, por su apoyo, y por enseñarme lo importante que es la unidad familiar.

¡Mi Ximenunchis! Gracias por preocuparte por mí, por estar conmigo "pa' las que sea" (literalmente), por tenerme paciencia, por ofrecerme sopita cuando estaba enferma, por hacerme reír a carcajadas y por esa personalidad tan tranquila que tienes, que siempre me transmite serenidad. Gracias por acompañarme todos estos años junto a mi Coco Chanel, y por haberte convertido en una amiga incondicional. Fuiste de gran apoyo en los momentos más difíciles que viví aquí y por eso y mucho más te llevas contigo un pedacito de mi corazón.

Gracias a todas esas personas que fui conociendo en el CIC, que hicieron mucho más ameno mi trabajo diario en el laboratorio, nunca faltó la charla en los pasillos y la buena energía. Ale, gracias por preocuparte por mí y por tu apoyo, cuida mucho de la linda Paulis y mucha fuerza. Alicia, fue justo al final que comenzamos a hablar (desafortunadamente), pero me encanta esa espontaneidad y sinceridad que te caracterizan, gracias por darme ánimos en todo momento. A Nacho "chopito" por 
todos los momentos que compartimos y por sacar tiempo para ayudarme con la tesis. ¡A mi uruguaya favorita! ¡Mi Lau! Gracias por los detalles, por tu experiencia, por esa madurez y comprensión, por esas palabras exactas en el momento indicado.

A mi combo Colombiano, que llegamos a un país desconocido buscando oportunidades, siguiendo nuestros sueños, Tatys, Mona, Andrés, Leo, Jenny María, gracias por ser parte de esta gran aventura y por compartir tan buenos momentos.A Leo y Jenny María muchas gracias por el apoyo incondicional, por todo lo vivido juntos, por nuestros viajes (iqué bien lo pasamos!), por contar siempre conmigo, por los fines de semana exprés de visita, y por consentirme tanto, y muy en especial a mi Jenny María, nunca olvidaré cuando viajamos juntas por primera vez a España, con nerviosismo de no saber lo que nos esperaba, con un montón de sueños guardados en nuestra maletas, gracias por siempre cuidarme, por escuchar mis quejas, por aconsejarme, por ser mi amiga incondicional, gracias por estar junto a mí en los buenos y los malos momentos, gracias por llorar conmigo, aún recuerdo el día que te despediste porque ya volvías definitivamente a Colombia, que difícil fue despedirme de ti, no sé cuántas veces dijimos adiós y al final por más que tratamos de evitarlo terminamos llorando (ivaya dos!). Se terminaron nuestras aventuras aquí, pero tenemos muchos lugares que aún no hemos visitado, así que tenemos que prepararnos para hacer más recuerdos, ve alistando las maletas junto con Leo.

A mi querida Choco, mi casi-hermana adoptiva, podrán pasar años y años y sé que siempre podremos contar la una con la otra, gracias por estar siempre pendiente, por preocuparte por mí, por enviarme tanta energía para seguir adelante, por los detalles y por mostrarme que con esfuerzo y dedicación siempre se llega a la meta.

Gracias a mi familia, sin ellos esto no sería posible. A mis abuelitas que siempre me dejan muy claro lo mucho que me quieren, a mi tía Done, Uriel y primos porque siempre tuvieron un huequito para mí en su casa, por preocuparse por mi y cuidarme como una hija más. A todos mis tíos, primos y gente que quiero como propia familia, gracias por apoyarme incondicionalmente, por sus llamadas y mensajes. Esa fuerza que me enviaron fue de gran ayuda para lograr mi sueño.

A roro por cuidar de mi familia, por esa amabilidad y empuje. Por enseñarme que con fuerza de voluntad se llega lejos. A mis hermanos, Lina, que chica tan inteligente eres y que pícara también, espero poder cuidarte y conocerte mejor. A mi consentido y mimoso Junior, eres sazón para mi vida, me haces reír, enojar, preocupar, llorar y algunas veces estornudar en esas ocasiones cuando me pongo alérgica y no quiero que te acerques porque te has portado mal, ite quiero mi niño! A mi hermana, Monicongo, mi talón de Aquiles, ¿qué haría yo sin ti? Siempre juntas, nunca soltaré tu mano, nunca lo he hecho desde el día que naciste y me enamoré de ti y nunca lo haré. Gracias por estar siempre ahí para mí. 
Mami gracias por ser extraordinaria, por tu sacrificio, por tu consuelo, por tus peleas, por tu espera, por tu calidez y paciencia, por enseñarme a ser disciplinada y constante, por ser el pilar de nuestras vidas, por siempre ser mi fuerza y empuje, ite mereces lo mejor mami! Ya cargaste mucho tiempo con mis hermanos y conmigo, ahora es mi turno.

Y por último, el agradecimiento más difícil de escribir, el tuyo papi. No sé ni por dónde comenzar, el silencio y la sensación de vacío no permiten la claridad de mis pensamientos, pero haré mi mejor esfuerzo por ti, porque te lo mereces. Eres la razón más fuerte y la inspiración más grande de terminar esta etapa de mi vida, de cumplir mi objetivo. Siempre has sido mi ejemplo a seguir, esa fuerza, inteligencia y dedicación tuya, son los rasgos que quiero adoptar en mi propia vida. Gracias por cuidarme, por consentirme, por ser mi polo a tierra, por tus consejos, por tus regaños, por tu sacrificio, por tu preocupación, por hacer de mí la mujer que soy hoy en día, porque sin ti no lo hubiera logrado. ¡Qué buen trabajo hiciste con nuestra familia! ¡Estoy muy orgullosa de ti! Me duele en el alma no poder decirte todo lo que siento personalmente, me duele en el alma que el tiempo y la vida me hayan traicionado, ahora solo espero que cuando susurre estas palabras para ti, el viento se encargue de llevarlas a tus oídos: ¡Papi lo logramos!

Gracias a todos por hacer de mi vida en España una experiencia profesional y personal excepcional.

... y eso que solo quería escribir "unas cuantas líneas". 



\section{"Quien no haya experimentado la irresistible atracción de la ciencia, no podrá comprender su tiranía” Mary Shelley -Frankenstein o el moderno Prometeo-}
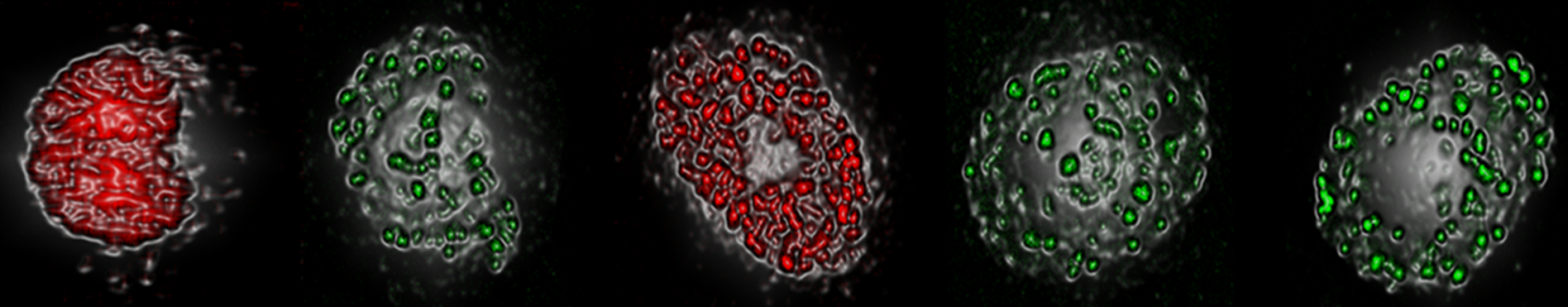

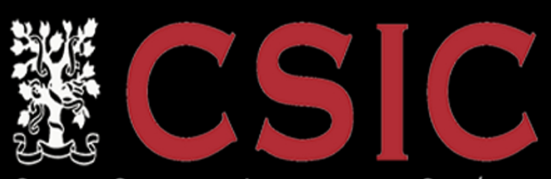

CONSEJO SUPERIOR DE INVESTIGACIONES CIENTÍFICAS

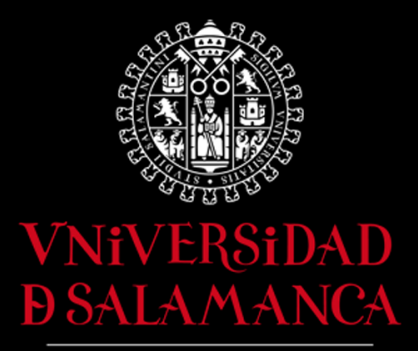

CAMPUS DE EXCELENCIA INTERNACIONAL

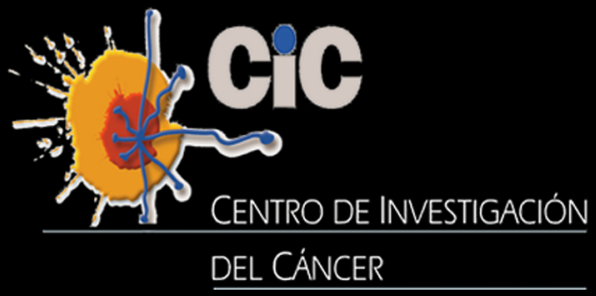

